\title{
Habitação Coletiva Popular na Área Central de Campinas:
}

Tendências e Caracterização

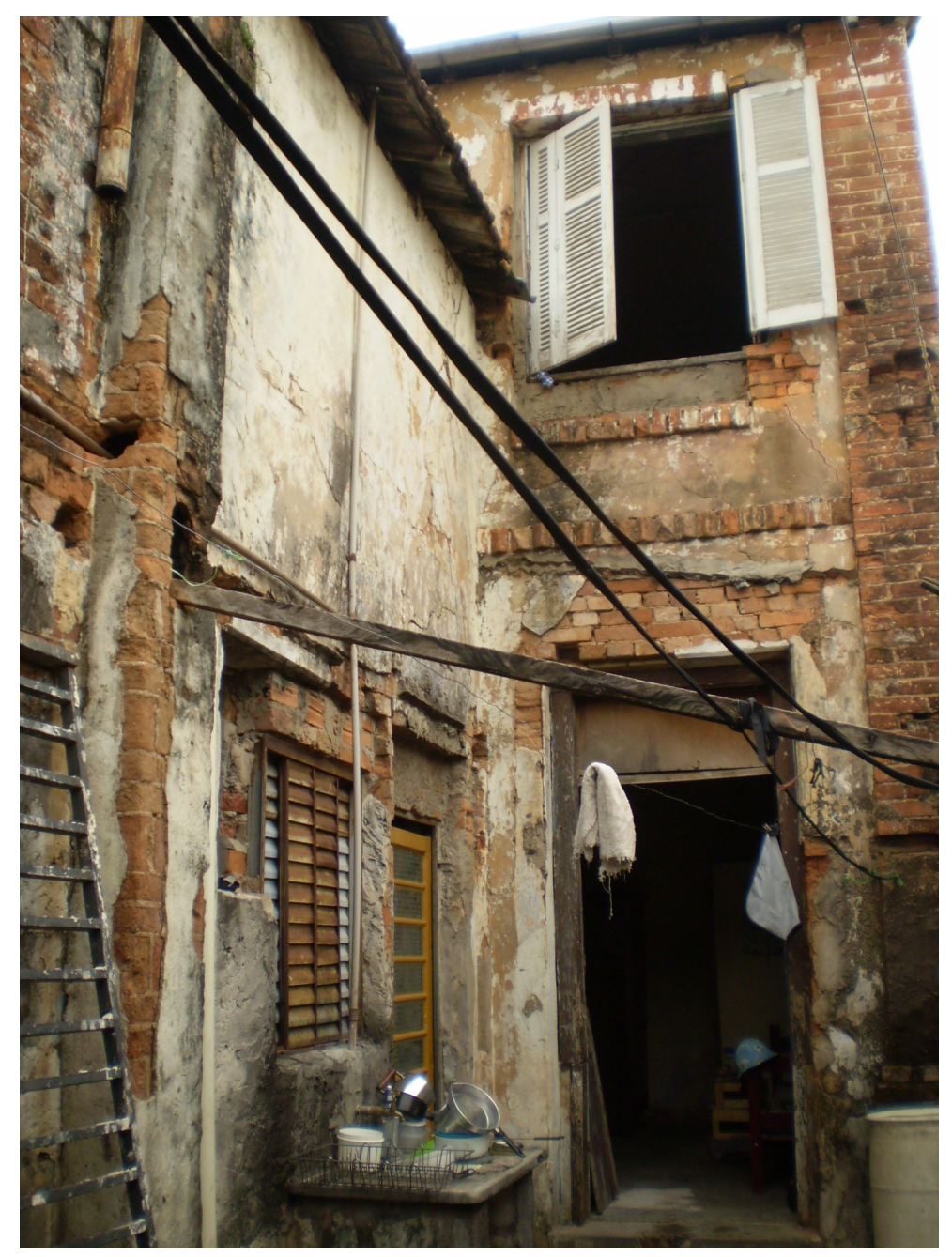

Camila Moreno de Camargo

Mestranda

Profa. Dra. Telma de Barros Correia

Orientadora

Escola de Engenharia de São Carlos - USP

São Carlos/ Janeiro 2010 


\section{Habitação Coletiva Popular na Área Central de Campinas:}

\section{Tendências e Caracterização}

Dissertação de Mestrado submetida ao Programa de Pós Graduação em Arquitetura e Urbanismo, Área de concentração em Teoria e História da Arquitetura e Urbanismo da Escola de Engenharia de São Carlos.

Camila Moreno de Camargo Mestranda

Profa. Dra. Telma de Barros Correia Orientadora

São Carlos / SP

Janeiro de 2010 
AUTORIZO A REPRODUÇÃO E DIVULGAÇÃO TOTAL OU PARCIAL DESTE TRABALHO, POR QUALQUER MEIO CONVENCIONAL OU ELETRÔNICO, PARA FINS DE ESTUDO E PESQUISA, DESDE QUE CITADA A FONTE.

Ficha catalográfica preparada pela Seção de Tratamento da Informação do Serviço de Biblioteca - EESC/USP

Camargo, Camila Moreno de

Habitação coletiva popular na área central de campinas : tendências e caracterização / Camila Moreno de Camargo ; orientadora Telma de Barros Correia. -São Carlos, 2010

Dissertação (Mestrado-Programa de Pós-Graduação em Arquitetura e Urbanismo e Área de Concentração em Teoria e História da Arquitetura e Urbanismo) -- Escola de Engenharia de São Carlos da Universidade de São Paulo, 2010

1. Habitação. 2. Cortiço. 3. Campinas. 4. Área central. 5. Política pública. I. Título. 


\section{AGRADECIMENTOS}

Finalizar uma pesquisa de mestrado é o término de uma etapa da vida carregada de leituras, reflexões, questionamentos sobre determinada temática. Hoje, vejo que todo este processo, que envolveu o pensar, me aproximou das diversidades urbanas e acabou por misturar-se ao processo de formação de mim mesma, enquanto cidadã consciente de meu papel nas relações sociais presentes na cidade. É inevitável reconhecer as muitas contribuições que recebi direta ou indiretamente, em menor ou maior grau, de cada pessoa que cruzou este percurso.

Agradeço primeiramente aos Profs. Nuno de Azevedo Fonseca, Mário Attab Braga, Marisa Varanda Teixeira Carpintéro e André Luiz Queiroz Blanco, pela confiança, amizade e apoio, durante o período em que fui sua aluna na graduação, me instigando a refletir o ideário urbano, enquanto cenário de uma teia de relações que se estabelecem e se transformam constantemente, e nosso papel, enquanto arquitetos urbanistas, e principalmente enquanto cidadãos, no estabelecimento destas relações, levando-me a tornar uma pesquisadora no campo da história e sociologia urbana. Da mesma forma, agradeço a Profa. Dra. Cibele Saliba Risek, que, através da disciplina "Teorias e Concepções da Modernidade" (que cursei por três vezes distintas, dada as ricas trocas proporcionadas), me instigou a fazer novos questionamentos e a enxergar novas possibilidades de leituras sobre a temática que já vinha desenvolvendo, e muito contribuiu para a elaboração e revisões do plano de pesquisa, e construção das linhas que norteiam esta dissertação de mestrado. Na mesma linha, agradeço a minha tia e amiga Eleni Moreno, socióloga, que desde sempre me foi a maior fonte inspiradora para este caminho que decidi trilhar. Foram muitas as conversas e orientações - que muito me enriqueceram -, e, sobretudo, carinho, amizade, acolhimento e cuidados em tantos e tantos momentos de pesquisa e trabalho.

Agradeço ao meu marido, Camilo, pelo carinho e apoio em todo o processo da pesquisa. Pelo interesse e troca constante, através das infindáveis conversas, sobre a cidade, sobre o ser humano e a relação entre os mesmos, que muito contribuíram para tornar o olhar cada vez mais apurado, e sensível às questões que surgiam. Aos meus pais, Aureliano e Eliane, e minhas irmãs Lidia e Daniela, minha imensa gratidão por terem atuado diretamente em minha educação e formação, apoiando indiscriminadamente todas as minhas escolhas, com muito afeto e amizade. Às crianças Maria e Moreno, por encherem minha vida de alegria todos os dias, na fase 
final da pesquisa, o que contribuiu para me fazer relaxar em muitos momentos de aflição, dada a complexidade em se encerrar anos de pesquisa.

Agradeço também ao meu querido amigo Lucas Cestaro, fiel companheiro em todo este processo, que mais do que amizade e cumplicidade, me enriqueceu com suas crenças e ideais por um mundo democrático e melhor. Meus sinceros agradecimentos também à Monica B. Frandi Ferreira e Raquel Ferreira, amizades conquistadas durante a pesquisa, através das "indas e vindas" de Rio Claro a São Carlos, pelos divertidos e - às vezes - sérios "papos" de nossas viagens, e mais ainda por termos consolidado nossa amizade e confiança, na certeza que ainda renderá bons frutos.

À minha orientadora Profa. Dra. Telma de Barros Correia, pelas observações, comentários precisos e hipóteses trabalhadas para possíveis correções de rumo. Pelo carinho, confiança e liberdade que depositou em mim, e o constante acompanhamento quanto às atividades desenvolvidas. Da mesma forma, agradeço aos Profs Drs. Ari Vicente Fernandes e Sarah Feldman pelas colaborações precisas e encorajadoras durante a banca de qualificação que nortearam o término e correções dos rumos deste trabalho.

Ao CNPq - Conselho Nacional de Desenvolvimento Científico e Tecnológico, que me concedeu bolsa de estudos, imprescindível para o andamento desta pesquisa.

Às amigas arquitetas urbanistas, sempre presentes, Paola Morini, Mariana Biasi, Maria Laura Caveanha e Laura Pezolatto, pela eterna torcida.

Minha imensa gratidão e eternos agradecimentos! 


\section{SUMÁRIO}

$\begin{array}{lr}\text { Resumo } & 9\end{array}$

$\begin{array}{ll}\text { Abstract } & 11\end{array}$

Introdução 15

Capítulo 1

Habitação Coletiva Popular em Áreas Centrais 27

1.1. A moradia popular - origem e conceituação 29

1.2. Ações e Programas Habitacionais voltados à produção 47 de Habitação de Interesse Social em áreas centrais metropolitanas - experiências recentes

1.3. Promoção Pública de Habitação de Interesse Social 72 em áreas centrais - possibilidades e limites

\section{Capítulo 2}

Processo de Estruturação Urbana e Habitação Popular em Campinas

2.1. A emergência dos cortiços 81

2.2. A ação do estado e a regulamentação diante das 89 moradias coletivas no centro

2.3. Consolidação e expansão de outras formas de habitação 97

2.4. Reconhecendo o cortiço em áreas centrais enquanto 114 modalidade de habitação popular atual

\section{Capítulo 3}

Habitação Coletiva Popular na área central de Campinas: características e conflitos

3.1. Caracterização quanto às características físicas e condições do imóvel

3.1.1. Edificação degradada

3.1.2. Edificação abandonada

3.1.3. Edificação inacabada 
3.2. Caracterização quanto à forma de ocupação 152

3.2.1. Cortiço 152

3.2.2. Pensão ou Hotel 158

3.2.3. Invasão 163

3.3. Conflitos 166

3.4. Ações recentes 172

$\begin{array}{lr}\text { Considerações Finais } & 179\end{array}$

$\begin{array}{lr}\text { Índice iconográfico } & 185\end{array}$

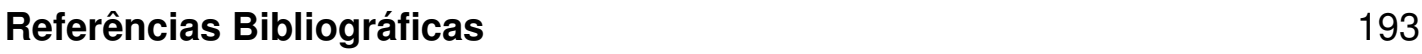




\section{RESUMO}

A cidade de Campinas, como resultado das transformações econômicas e urbanas experimentadas nas três últimas décadas, teve redefinido seu perfil e seu papel de centro urbano médio, assumindo características de sede de uma metrópole emergente no interior do Estado, inclusive com a concentração dos socialmente excluídos. Tomando como referência o processo de estruturação urbana e a origem e história da habitação popular na cidade, essa dissertação de mestrado se apresenta enquanto resultado do trabalho de pesquisa iniciado a partir de estudos sobre as tendências recentes de configuração das áreas centrais metropolitanas, que apontam para a presença de cortiços, enquanto alternativa habitacional popular crescente. Destaca-se a importância em se alterar de forma significativa o perfil de condição de apropriação da moradia na cidade, que ainda se estrutura na produção ou aquisição de novas unidades habitacionais nos bairros periféricos, considerando outras tendências na movimentação e distribuição espacial da pobreza. A pesquisa consiste na análise e caracterização das habitações coletivas populares existentes na área central de Campinas, a partir das características e condições físicas, e a forma de ocupação e apropriação dos imóveis identificados como habitação coletiva popular. Além disso, organizamos os depoimentos coletados junto aos atores envolvidos com a questão, de forma a apontar os conflitos, as regras internas estabelecidas e as perspectivas e principais anseios desta população. A pesquisa justifica-se, tendo em vista a constatação da presença relevante deste tipo precário de habitação identificada ora como cortiços, ora como hotéis e pensões - em contraponto à ausência de dados sobre os mesmos. 


\begin{abstract}
The city of Campinas had its medium urban center profile redefined as a result of urban and economic transformations experienced in the last three decades. The city has assumed the characteristics of an emerging metropolis in the State of São Paulo, including the concentration of socially excluded people. This master's thesis is a result of a research started from studies on recent trends in the central metropolitan areas settings, that indicate the presence of beehives growing like a popular alternative habitation. The main references for this thesis are the process of urban structure and the popular habitation origin and history in the city. It is highlighted the importance of significative changes in the ownership habitation condition in the city, that is still structured in the production or acquisition of new houses units in suburbs, taking into account other trends in the movement and spatial distribution of poverty. This research consists in the analysis and characterization of popular collective habitation in Campinas central area, its characteristics and conditions, the way of occupation and ownership of property identified as popular collective habitation. It was organized the testimonies gathered from the actors involved in the situation, to point out the conflicts, internal rules set and the main perspectives. The relevant existence of this type of poor housings - identified as beehives or hotels and pensions - and the lack of data on them justify this research.
\end{abstract}




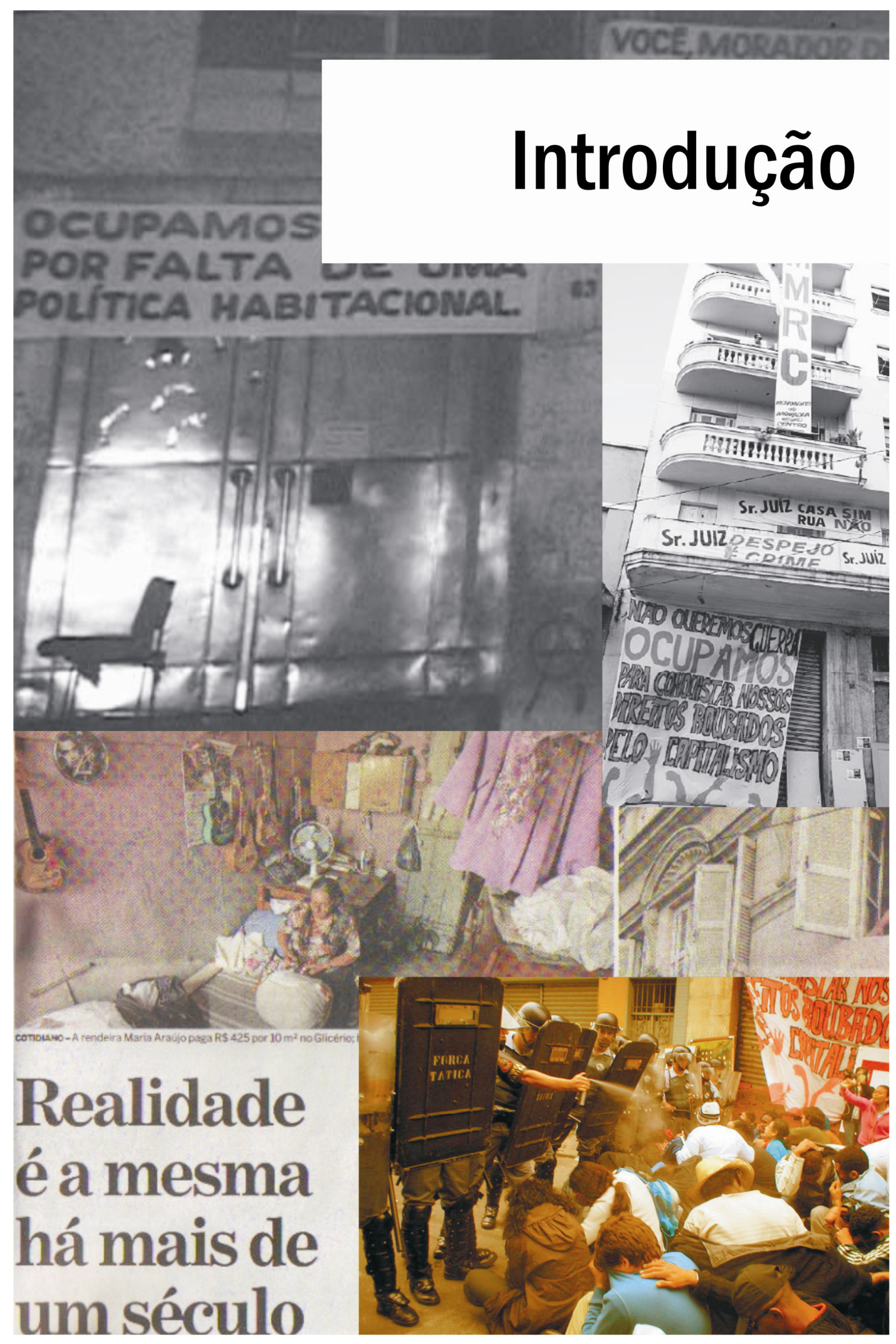


As grandes cidades brasileiras vêm apresentando tendências recentes de configuração que se inserem no processo de crescimento das cidades. Este processo se caracteriza pela extensão da mancha urbana em direção às periferias - para 0 assentamento da população de baixa renda -, e em direção a novas áreas de valorização imobiliária para assentar setores de atividades relacionados à alta renda. No mesmo processo, nas últimas décadas, muitas famílias de classe de renda média optaram por sair do da área central preferindo morar em apartamentos ou casas localizados em bairros segregados, buscando alternativas à moradia nas regiões centrais. Para as famílias de menor renda, o acesso às unidades deixadas vazias no centro era - e ainda é - economicamente difícil, e as opções mais viáveis continuaram sendo as favelas e os loteamentos precários na periferia. No entanto, em algumas áreas centrais, observa-se a presença crescente de famílias para as quais essa localização é importante em função, especialmente, da proximidade do trabalho. Nesse contexto, Pasternak, referindo-se à cidade de São Paulo, coloca a favela como uma alternativa ainda em crescimento (2002: p.177-186), a casa própria na periferia como uma alternativa em declínio (2002: p.187-188) e os cortiços em áreas centrais como uma alternativa em crescimento explosivo (2002: p.188-189).

As causas de tal processo são múltiplas, assim como as características assumidas em cada cidade e o modo como esta assimila tais transformações. Ainda assim, destacam-se alguns aspectos comuns, como a degradação do patrimônio histórico e cultural, a concentração de moradias precárias e insalubres, principalmente cortiços, a concentração de atividades informais, a mudança no perfil sócio-econômico dos moradores, dos usuários e das atividades locais, a concentração de grupos sociais vulneráveis ${ }^{1}$ e, ainda, uma tendência à saída de serviços públicos e privados para outras centralidades (Ministério das Cidades/ Agência Espanhola de Cooperação Internacional - AECI, 2008: p.12).

Nesse contexto, Bonduki (2000: p.73-82) ressalta o passo fundamental dado pelos movimentos organizados de luta por moradia, no início da década de 1990, que passaram a reivindicar programas habitacionais na área central da cidade de São

\footnotetext{
${ }^{1}$ Pesquisa realizada em 2000 pela Fundação Instituto de Pesquisas Econômicas (FIPE), mostrou que mais de metade dos quase 9 mil moradores de rua do município de São Paulo encontram-se na área central da cidade. Mostrou também que essa população depende das condições que as ruas desta área Ihes oferecem para sua sobrevivência diária, em termos de abrigo, alimentos, renda monetária e segurança e que, portanto, a requalificação da área central, pensada ou não no contexto de programas de moradia popular, deve incluir os moradores de rua como parte integrante da questão (SCHOR, S., in: BONDUKI: 2001: p.30).
} 
Paulo, ocupando os prédios vazios da região². Nesse momento, foi deflagrado um debate intenso na luta pela reforma urbana e pelo direito à cidade, atrelando a questão habitacional e a vacância em áreas centrais à necessidade de viver em locais dotados de infra-estrutura, equipamentos sociais e empregos.

Dominar o centro e o acesso a ele representa não só uma vantagem material e concreta, mas também o domínio de toda uma simbologia. Os centros urbanos principais são, portanto (ainda são, em que pesem suas recentes decadências), pontos altamente estratégicos para o exercício da dominação (VILLAÇA, 2001: p.244).

Reaparecem assim, como fato urbano importante, os cortiços, num processo diferente, sob determinados aspectos, daquele vastamente caracterizado do final do século XIX e início do século XX. As tipologias, as formas de gestão e os níveis de habitabilidade agora observados apresentam expressivas variações nas análises, legislações, relatórios e pesquisas que abordam a temática, ainda discutíveis quanto às conceituações e estimativas.

Segundo PICCINI, atualmente a situação de vida nos cortiços não mudou muito em relação à precariedade, à densidade de ocupação e à ilegalidade que sempre os caracterizaram, ou seja, forte aglomeração, superlotação, mescla e sobreposição de funções, com uma conseqüente e acentuada pobreza, "acarretando problemas graves à saúde que posicionam o cortiço como uma opção socialmente inferior à favela" (apud SANTOS, 2002: p.36). Esse tipo de moradia ainda é também um negócio imobiliário de alta lucratividade ${ }^{3}$, como o foi em outros momentos de sua história nas cidades brasileiras devido, entre outras coisas, à máxima subdivisão de cada lote, e/ou

\footnotetext{
2 Segundo Bonduki (2001: p.52), na cidade de São Paulo, os edifícios ocupados por "sem teto" são em grande parte propriedade do Governo Estadual, Governo Federal, ou de bancos privados, desocupados há muito tempo por motivos como, por exemplo, a mudança de localização dos órgãos públicos ou dos centros financeiros, o enxugamento de estrutura dos bancos e órgãos do estado, ou a não utilização de imóveis recebidos como pagamento de dívidas. Há também edifícios privados que ficaram ociosos devido à perda de valor de mercado como antigos hotéis, escritórios e residências, que os proprietários deixam fechados, aguardando uma possível revalorização imobiliária.

3 Já em 1999, Kohara (KOHARA e PICCINI, 1999) coloca que, apesar das condições precárias de habitabilidade e renda familiar baixa, os valores dos aluguéis pagos nos cortiços analisados na cidade de São Paulo, são altos quando comparados com o valor cobrado pelo mercado formal, o que fazia com que os encortiçados comprometessem em média $50 \%$ da renda familiar apenas com as despesas da moradia. Os encortiçados pagavam, em média, $\mathrm{R} \$ 13,17$ por metro quadrado, enquanto que o aluguel de casas na área da pesquisa estava em torno de $\mathrm{R} \$ 7,40$ por metro quadrado, os de escritórios no centro da cidade atingiam um máximo de $R \$ 11,97$ e os escritórios na Av. Faria Lima estavam disponíveis para locação por $\mathrm{R} \$ 14,17$ por metro quadrado. Dez anos depois, em 2009, a situação não mudou muito. Por cômodos de $10 \mathrm{~m}^{2}$ em média, os encortiçados pagam, em média, $\mathrm{R} \$ 28,00$ por metro quadrado na área central de São Paulo. Segundo dados do Sindicato da Habitação de São Paulo (Secovi-SP), o valor mais alto de aluguel praticado no município de São Paulo é cobrado na região sul, onde o metro quadrado de um apartamento de quatro dormitórios sai por R \$23,00 (MANSO, Bruno Paes. "Aluguel mais caro de SP é de cortiço". O Estado de São Paulo, São Paulo, 12 de abril de 2009. Cidades/ Metrópole, Caderno C, p. C1).
} 
cômodo, e à redução de despesas com impostos e com a manutenção do imóvel (KOHARA, 1999).

Nas cidades de São Paulo e Santos, pesquisas ${ }^{4}$ indicam importantes aspectos comuns quanto à caracterização dos cortiços, como as condições precárias de moradia e as relações de locação, geralmente marcadas por cobranças abusivas de aluguéis e taxas. A ilegalidade dos contratos e a convivência direta com a pressão dos proprietários e seus prepostos - administradores ou intermediários - deixa as famílias em situação extremamente fragilizada.

Segundo tais pesquisas, a maioria da população encortiçada é adulta, organizada em famílias pequenas, onde se destacam os arranjos unipessoais. Quanto à inserção dos chefes de família encortiçadas no mercado de trabalho se observa que uma parcela expressiva dos chefes é assalariada com carteira de trabalho assinada, e parte substancial, mas menos significativa, agrupa chefes autônomos. Ainda assim, a maioria dos encortiçados sobrevive de trabalhos informais, sem registro em carteira, sendo este um dos motivos para a informalidade das relações locacionais, já que os moradores não têm possibilidade de comprovar sua renda. As famílias encortiçadas concentram-se na faixa de renda familiar total de até três salários mínimos, embora seja expressiva a parcela de famílias com renda entre três e cinco salários mínimos, e ainda com mais de cinco salários mínimos ${ }^{5}$. O comprometimento da renda familiar com o aluguel é alto, ficando em torno de $50 \%$.

Outro traço comum aos encortiçados refere-se ao fato da maior parte dessa população ser oriunda de outros cortiços, pensão ou casa de cômodos, antes de se instalar no domicílio atual ${ }^{6}$. Essa constatação confirma a grande rotatividade

\footnotetext{
${ }^{4}$ Entre tais pesquisas destacam-se: Fundação Instituto de Pesquisas Econômicas (FIPE). "Diagnóstico e plano de ações para o mercado de moradia de aluguel e identificação de obstáculos para aquisição de novas moradias pelas famílias de baixa renda". São Paulo, v.1, out. 1997.; KOHARA, Luiz Tokuzi. "Rendimentos obtidos na locação e sublocação de cortiços: estudos de casos na área central da cidade de São Paulo". 1999. Dissertação (Mestrado), FAU-USP, São Paulo, 1999; SÃO PAULO (estado). "Programa de Atuação em Cortiços - PAC: município de São Paulo - setores básicos de intervenção". São Paulo: CDHU-SEADE, 2002; SÃO PAULO (estado). "Programa de Atuação em Cortiços - PAC: município de Santos - setores básicos de intervenção". São Paulo: CDHU-SEADE, 2002a; SILVA, Helena Menna Barreto. "Habitação no centro de São Paulo: como viabilizar essa idéia?" São Paulo: LabHab/ FAUUSP, 2000.

${ }^{5}$ A pesquisa FIPE (1997) mostrou que a população moradora de cortiços não é homogênea, o que exige que se qualifique a análise feita com valores médios de desembolso mensal e de custo dos imóveis. Ou seja, diferenças importantes são encobertas pelos valores médios, diferenças estas cruciais para a determinação da capacidade de pagamento das famílias encortiçadas e suas chances de acesso à programas de financiamento à moradia, o que exige que sejam consideradas alternativas de financiamento distintas e projetos alternativos (SCHOR, S., in: BONDUKI: 2001: p.30).

${ }^{6}$ Destaca-se que as pesquisas citadas não diferenciam o cortiço, da pensão ou casa de cômodos, e que, como veremos no Capítulo 3, em Campinas, estas configurações apresentam diferenças consideráveis,
} 
observada nos cortiços, comprovada também pelo pouco tempo de permanência no local de moradia, ainda que a moradia anterior se localize na mesma região da atual.

Em relação às características das moradias, registram-se o uso coletivo de banheiro, pia e tanque de lavar roupa, e o congestionamento permanente no uso desses equipamentos. Registram-se também a superlotação de pessoas, a sobreposição de usos nos cômodos, a ausência ou deficiência de iluminação natural e de ventilação nos cômodos, a coabitação involuntária com pouca ou nenhuma privacidade, a precariedade na manutenção da edificação, causando infiltrações, entupimentos, etc.; a sobrecarga da rede elétrica com risco de incêndio, as condições sanitárias críticas e a deterioração dos imóveis.

Apesar dessas questões, os moradores de cortiços normalmente apontam vantagens nesse tipo de habitação no centro da cidade. Dentre os fatores de destaque estão a proximidade do local de trabalho e a facilidade no deslocamento (a maioria dos chefes de família gasta menos de meia hora para chegar ao local de trabalho e faz o percurso a pé), a maior oferta de empregos, de infra-estrutura e de serviços urbanos (creche, escola e hospital) e o preço acessível do aluguel. Entre as desvantagens apontadas estão a poluição, o barulho, o trânsito, a sujeira e a violência.

O adensamento de bairros centrais, tendo como pressuposto o aumento da oferta habitacional de interesse social, é considerado por muitos como uma forma adequada de potencializar o uso de equipamentos e serviços já implantados e evitar a contínua dispersão das populações em periferias distantes e destituídas de equipamentos e infra-estrutura básica. É também considerado como uma forma de garantir a diversidade funcional, além de, ao dinamizar áreas centrais já consolidadas, promover a redução da segregação social e espacial e a melhoria das possibilidades de integração de diversas parcelas da população à economia e à vida urbana, que historicamente encontra no lugar central seu local privilegiado de manifestação.

Esta condição pode explicar a tendência mundial de práticas de intervenção urbana, referenciadas em vários conceitos - reabilitação, redesenho, reversão, renovação, recomposição, revitalização, recuperação, reurbanização, regeneração, reapropriação, repovoamento, reconversão ou requalificação - relacionadas ao processo de declínio e deterioração dos espaços, causado, sobretudo pelas políticas deliberadas de grandes interesses imobiliários que contam com a cumplicidade ou

principalmente no que tange às relações e dinâmica interna estabelecidas, apesar das características físicas se apresentarem semelhantes. 
omissão do poder público. A pesquisadora Regina Meyer destaca que os temas mais debatidos desse amplo espectro, têm sido:

\begin{abstract}
a erosão dos espaços públicos conduzida pela permanente e intensa adaptação do Centro às exigências da circulação viária [...]; a esterilização urbana, consumada em nome de práticas esteticistas e passadistas, pouco comprometidas com as funções contemporâneas das metrópoles; e as práticas de renovação urbana, nas quais a expulsão e a substituição dos antigos moradores, muito recorrente em processos desse tipo como 'gentrification', por novos grupos sociais é desenvolvida em nome da reversão do processo de declínio habitacional e urbano (MEYER, 2001: p.31).
\end{abstract}

$\mathrm{Na}$ Europa, em algumas cidades italianas e francesas, a discussão quanto às formas de intervir no centro das cidades tem considerado esta uma questão, sobretudo de patrimônio, com grande ênfase à questão da moradia. A preservação de imóveis começa a ser tematizada em contraposição a projetos de renovação urbana das áreas centrais que tinham como princípio a "tábula rasa". Solà-Morales (2001: p.110) ressalta, neste sentido, o valor de centro como patrimônio de moradia e estoque de habitação, ao se pensar ações e estratégias de intervenção para esta área.

Uma experiência de grande destaque é a implementada na França, após a Segunda Guerra Mundial, quando o país se viu diante de uma crise de moradia cujas causas não se deviam somente às conseqüências dos bombardeios ${ }^{7}$, mas também às conseqüências da política governamental conduzida até então, que não levara em conta o enorme êxodo rural. Essa situação se agravou por uma política quase contínua de congelamento dos aluguéis, desestimulando o investimento privado e criando um cenário de insuficiência e inadaptação da oferta, além de grave estado de deterioração dos antigos imóveis existentes. A partir de meados da década de 1950, o Estado Francês se viu fortemente pressionado no sentido de definir uma política nacional para moradia. Foi então, criado um sistema de subsídios, empréstimos e incentivos fiscais coerentes com a diretriz política que definia que o papel do Estado na produção habitacional era apenas incentivar a produção, sem intervir diretamente. $\mathrm{Na}$ década de 1960, o Estado Francês assumiu uma posição intervencionista ${ }^{8}$, tanto

\footnotetext{
${ }^{7}$ Foram aproximadamente 500.000 moradias destruídas e quase um milhão deterioradas em maior ou menor grau.

${ }^{8}$ As reflexões sobre a evolução das cidades e sobre os problemas urbanos levaram à implementação dos procedimentos que permitiam a "reconquista dos centros das cidades", como as operações de Renovação Urbana (Renovation urbaine) e os Setores Preservados (Secteurs sauvegardés), através da "Lei Malraux", mecanismo específico de urbanismo para preservar o valor patrimonial desses bairros antigos, além de
} 
em relação à moradia pública quanto à privada, ocupando aos poucos o lugar do setor privado na solução do problema habitacional. Mesmo assim, muitos franceses ainda moraram em cortiços até os anos 1970. A partir desta década, as novas políticas são igualmente originadas a partir de reflexões sobre o financiamento da moradia e sobre o lugar das edificações antigas nas políticas habitacionais.

A política de reabilitação urbana na França tem origem em 1975 com a divulgação do relatório "Rapport sur l'amélioration de l'habitat ancien" elaborado por Simon Nora e Bertrand Eveno. A pesquisadora francesa Nancy Bouche afirma que "este relatório constituiu, na verdade, a certidão de nascimento de um formidável movimento de reabilitação imobiliária que tomou conta da França, tanto no setor privado quanto no setor público" (informação pessoal ${ }^{9}$ ). O "Fundo de Reordenamento Urbano" ("Fond d'aménagement urbain" - FAU) foi criado em 1977 para financiar novas operações através de políticas contratuais apoiadas em estudos preliminares, e também as chamadas "Operações Programadas de Melhoria do Habitat" ("Opérations programmées d'amélioration de l'habitat" - OPAH). Era preciso estimular o mercado privado, auxiliando os proprietários a reinvestirem nas suas moradias (sobretudo a moradia locativa), graças a uma política de provimento de equipamento, de embelezamento e de revalorização dos bairros, sustentada por subsídios concedidos às cidades pelo FAU. Atualmente a política de reabilitação urbana na França está apoiada nos seguintes princípios: direito à moradia digna, o que implica em aluguel acessível aos mais pobres; moradia de qualidade; auxílio estatal, cujo nível é aquele que a sociedade aceita em nome da solidariedade nacional; oferta suficiente de habitação; oferta qualitativa de moradia, com localização adequada para evitar a segregação social. A "Lei de Solidariedade Urbana" ("Loi Slidarité et Renouvellement Urbain" - SRU), aprovada em 2000, define no seu artigo 55, que todos os municípios ou aglomerações urbanas com mais de 50.000 moradores deverão ter, no mínimo, $20 \%$ de habitação social em seus territórios num prazo de 20 anos. A previsão é de que sejam produzidas 22.000 moradias sociais por ano, totalizando 450.000 ao final dos vinte anos ${ }^{10}$.

permitir sua restauração e sua adaptação às necessidades da vida contemporânea (BOUCHE, N., 2000, $s / p)$.

9 BOUCHE, Nancy. A Reabilitação na França: instrumentos e procedimentos. In: Gestão de Programas de Reabilitação Urbana. São Paulo: Ecole Nationale des Ponts et Chaussées (ENPC), Federação Nacional das Associações Pact-Arim e LABHAB/FAUUSP, 2000. Tradução de Helena Menna Barreto Silva. Mensagem recebida por cmcarq@hotmail.com em 13 de novembro de 2007.

${ }^{10}$ Idem. 
A pesquisadora Sarah Feldman (in: BONDUKI, 2001: p.20) destaca ações públicas implementadas em outras cidades européias, considerando como projeto paradigmático o da cidade de Bologna, na Itália, realizado durante a década de 1960, no contexto de governo da região da Emilia Romana, e que tinha representação majoritária do Partido Comunista. O plano se inscreve em uma perspectiva de política abrangente ao conjunto da cidade e foi elaborado com a participação da população. A política habitacional foi prevista para atender à população de baixa renda, estudantes e idosos e efetivada através de cooperativas de proprietários, da gestão coletiva de setores urbanos, da garantia de moradia do aluguel acessível, além de envolver um número elevado de desapropriações. O plano promovido para a área central coloca a intervenção do poder público em uma perspectiva de valorização do patrimônio arquitetônico e de contenção do processo de periferização. O centro, além de bem cultural, foi considerado patrimônio econômico que não poderia ser desperdiçado e entregue ao domínio da especulação imobiliária.

Em Lisboa, Portugal, o processo de intervenção em moradias no centro da cidade se iniciou como demanda de moradores, com a mobilização de dois bairros. $\mathrm{A}$ prefeitura de Lisboa assumiu o projeto por meio de estratégias associadas ao conceito de reabilitação urbana, que se alinhavam à experiência de Bologna, mantendo a população existente. Ainda segundo a autora, em Bologna e Lisboa, a participação do poder público foi fundamental, assim como a vinculação da política da área central à política urbana geral da cidade, e a associação da preservação de imóveis à manutenção da população residente (FELDMAN, in: BONDUKI, 2001: p.20).

Estas idéias ganharam representatividade no Brasil, a partir da década de 1980, principalmente através da experiência francesa ${ }^{11}$, tendo em vista a retomada do centro "abandonado" e "estagnado" por parte da população de classe de renda baixa e média baixa, motivada por fatores como a proximidade com o local de trabalho, o pleno atendimento em termos de infra-estrutura e a possibilidade do surgimento de novas oportunidades de vida. Ainda assim, e levando em conta a presença do cortiço, que volta a se destacar no cenário urbano enquanto alternativa habitacional barata para esta parcela da população,

a questão habitacional não está presente no receituário, que prevê para essas áreas apenas atividades de entretenimento, ou do setor lazer, terciário avançado. A habitação, quando aparece, se inclui na retórica da mistura de usos, e quando projetos habitacionais são realizados, se destinam à população de mais alta renda. Pode-se

\footnotetext{
${ }^{11}$ Através de convênios de cooperação técnica firmados entre os dois governos.
} 
afirmar que a habitação de interesse social não está em pauta nos projetos recentes (FELDMAN, in: BONDUKI, 2001: p. 20).

A pesquisa que originou esta dissertação se insere nesse debate premente quanto às novas tendências de configuração dos centros metropolitanos, destacando a importância da alteração significativa nas condições de apropriação da moradia voltada à classe de baixa renda - que ainda se estrutura na produção ou aquisição de novas unidades habitacionais nos bairros periféricos -, considerando-se outras tendências na movimentação e distribuição espacial da pobreza.

O cenário escolhido foi o da cidade de Campinas, estado de São Paulo, que, como resultado das transformações econômicas e urbanas experimentadas nas três últimas décadas, teve redefinido seu perfil e seu papel de centro urbano médio, assumindo características de sede de uma metrópole emergente no interior do estado de São Paulo, inclusive com grande concentração de pobreza. A articulação entre a política urbana e a política habitacional, no município, ainda é incipiente, com conseqüências de diferentes tipos: ocupação de áreas inadequadas para habitação; ocupação de áreas verdes e de áreas destinadas a equipamentos públicos nos loteamentos existentes; ocupação e adensamento de áreas desprovidas de equipamentos e de infra-estrutura em regiões periféricas; e pouca atenção às áreas centrais dotadas de infra-estrutura, como possibilidade de moradia para diferentes classes sociais.

A pesquisa teve como objetivo geral caracterizar a habitação coletiva popular, que se apresenta sob a forma de cortiços, hotéis e pensões na área central de Campinas, através da análise de tais habitações sob a esfera urbanística (mapeando e caracterizando as áreas em que estão inseridas), arquitetônica (apontando para aspectos físicos e relativos às formas de apropriação dos imóveis) e social (evidenciando os conflitos vivenciados pela população moradora). Justifica-se, tendo em vista a constatação da presença relevante deste tipo precário de moradia, em contraponto à ausência de dados sobre os mesmos. A pesquisa foi intitulada "Habitacão Coletiva Popular na área central de Campinas: tendências e caracterização" e foi desenvolvida desde fevereiro de 2007, junto ao programa de Pós-Graduação em Arquitetura e Urbanismo da Escola de Engenharia de São Carlos/USP, sob orientação da Prof. Dra. Telma de Barros Correia e apoio do CNPq.

O trabalho envolveu pesquisa bibliográfica sobre o tema abordado, levantamentos e sistematização de informações, obtidas através de pesquisa de 
campo, em documentos e em periódicos, material iconográfico e entrevistas. Trabalhamos nos campos da história, da arquitetura e urbanismo e das ciências sociais, em uma perspectiva interdisciplinar, enxergando a cidade enquanto rede complexa a solicitar confrontações.

A pesquisa bibliográfica reuniu instrumental teórico que forneceu subsídios às investigações dos dados específicos sobre o objeto de estudo, permitindo analisar as informações obtidas, estruturando-as segundo os sub-temas que norteiam os objetivos do trabalho. Abrange obras que tratam: da história e origem da habitação social no Brasil; da história e caracterização das habitações coletivas populares de aluguel e cortiços; da história de estruturação urbana de Campinas; das políticas e discussões voltadas para a habitação em áreas centrais metropolitanas, desde meados da década de 1980 até os dias atuais. Para tanto, foram consultadas a Biblioteca FAU/USP Cidade Universitária e Pós-Graduação; LABHAB/ USP; Biblioteca EESC/ USP; arquivos CDHU São Paulo - setor PAC (Programa de Atuação de Cortiços); Centro de Memória UNICAMP; Centro de Apoio Didático PUC Campinas; Biblioteca PUC Campinas, e outros.

Utilizamos também arquivos da COHAB/Campinas; Setor de Cadastro Fiscal Municipal de Campinas, Secretaria Municipal de Habitação de Campinas (SEHAB), Secretaria Municipal de Planejamento e Meio Ambiente de Campinas (SEPLAMA/ DEPLAN), Coordenadoria Setorial de Preservação Cultural de Campinas, Arquivo Municipal de Campinas, entre outros. A pesquisa de campo foi realizada através da coleta de depoimentos, entrevistas e registros iconográficos atuais, através de medições, desenhos e fotos.

Todavia, enfrentamos algumas dificuldades já esperadas, como a falta de registros na Prefeitura Municipal de Campinas, dado o ineditismo do trabalho e os interesses políticos e mercadológicos presentes no não reconhecimento da problemática habitacional existente na área central de Campinas, como veremos no Capítulo 3. No entanto, estas dificuldades não impediram a obtenção de dados para o cumprimento dos objetivos da pesquisa. Foram realizadas entrevistas ${ }^{12} \mathrm{com}$

\footnotetext{
12 Lia Afonso Ferreira de Barros (entrevista realizada em 16 de outubro de 2007, na CDHU - Rua Boa Vista, 170, 8a andar, Bloco 2, Centro, São Paulo - SP); Daisy Ribeiro (entrevista realizada em 21 de setembro de 2007, na Coordenadoria Setorial de Patrimônio Cultural - antiga Estação Ferroviária, Centro, Campinas - SP); Profa. Dra. Doraci Alves Lopes (entrevista realizada em 08 de janeiro de 2008, no endereço Avenida Antonio Carlos Couto Barros, 871, Sousas, Campinas - SP); Prof. Dr. Ari Vicente Fernandes (entrevista realizada em 15 de janeiro de 2008, na Prefeitura Municipal de Campinas, Secretaria de Planejamento e Desenvolvimento Urbano - Avenida Anchieta, 200, 19a andar, Centro, Campinas - SP).
} 
profissionais e estudiosos envolvidos com a problemática habitacional em Campinas e, de forma geral, com a questão habitacional em áreas centrais metropolitanas, além de enquetes com os moradores e usuários das unidades identificadas como habitações coletivas precárias na área central de Campinas, e profissionais da área da saúde, educação e assistência social, ligados a instituições localizadas e atuantes no perímetro de estudo, de forma a identificar os conflitos internos existentes e uma caracterização mais precisa acerca da questão.

No entanto, o andamento da pesquisa de campo mostrou a necessidade de uma revisão no procedimento metodológico previsto, que utilizava questionário sócioeconômico pré-elaborado ${ }^{13}$, a partir da qual adotamos a coleta de depoimentos dos atores envolvidos, de forma livre, sem perguntas pré-confeccionadas, préagendamento ou tempo máximo estipulado, de forma a se entender a permeabilidade e interfaces existentes entre as questões, embates e conflitos vividos por esta população. Mostrou-se necessário a ampliação do período previsto para visitas de campo, devido às dificuldades encontradas 'in loco', o volume de dados a serem coletados e o tempo gasto para sistematização das informações e entendimento das questões levantadas, visto que se trata de um levantamento inédito, sem material de apoio, a não ser fragmentos de informações que os diferentes atores envolvidos nos transmitiram.

Os dados foram complementados com a pesquisa de uso real do solo, através do qual foram mapeados os serviços gerais e de compras, os equipamentos de saúde e educação, as áreas verdes (praças e parques), os estacionamentos particulares, os hotéis, os edifícios degradados e/ou abandonados e as habitações coletivas - onde se classificam os cortiços, hotéis e pensões populares, e edifícios invadidos. A etapa seguinte foi dedicada aos trabalhos de organização, sistematização e análise do material levantado, para a elaboração dos capítulos teóricos que embasam a pesquisa.

A dissertação está estruturada em três capítulos. O primeiro está intitulado "Habitação Coletiva Popular em áreas centrais" onde organizamos a revisão bibliográfica que aborda o surgimento dos cortiços em fins do século XIX e sua configuração atual, as formas de enfrentamento da questão por parte do poder público e os principais limites e possibilidades para a promoção pública de habitação de

\footnotetext{
${ }^{13} \mathrm{~A}$ formulação deste questionário seguiu as linhas trabalhadas pelo Programa de Atuação em Cortiços (PAC), da CDHU, nos municípios de São Paulo e Santos, que compreendeu uma fase intensa de levantamentos preliminares e elaboração de diagnóstico, com sistematização e montagem de grande acervo iconográfico.
} 
interesse social em áreas centrais. Está organizado em três sub-itens, sendo o primeiro intitulado "A moradia popular - origem e conceituação", que trata da origem e primeiras conceituações dos cortiços, enquanto modalidade de habitação da classe baixa, das primeiras formas de enfrentamento e da normatização da construção por parte do poder público. O segundo, intitulado "Ações e Programas Habitacionais voltados à produção de Habitação de Interesse Social em áreas centrais metropolitanas - experiências recentes", destaca as tentativas de intervenção e promoção pública de habitação de interesse social em áreas centrais, tomando como referência o município de São Paulo, a partir da década de 1980. E o terceiro, intitulado "Promoção Pública de Habitação de Interesse Social em áreas centrais possibilidades e limites", que analisa os limites e possibilidades existentes para a promoção pública de Habitação de Interesse Social em áreas centrais.

O segundo capítulo, organizado sob o título "Processo de Estruturação Urbana e Habitação Popular em Campinas”, aborda o processo de desenvolvimento urbano de Campinas e suas conseqüências sobre a questão da habitação na cidade. Está, por sua vez, organizado em quatro sub-itens, sendo o primeiro intitulado " $A$ emergência dos cortiços", onde tratamos da primeira fase de expansão de Campinas, da consolidação da economia cafeeira, do surgimento dos primeiros cortiços, do surto de epidemia de febre amarela que assolou a cidade e das obras de infra-estrutura de cunho sanitarista. O segundo sub-item, "A ação do Estado e a regulamentação diante das moradias coletivas no centro", trata do desenvolvimento industrial de Campinas, dos primeiros códigos regulamentadores e das ações contra a presença de cortiços, do Plano de Melhoramentos Urbanos de Prestes Maia e da expansão contínua da cidade. O terceiro, "Consolidação e expansão de outras formas de habitação", destaca a formação da periferia urbana campineira, a intensificação do setor industrial, o acentuado crescimento econômico e populacional, a atuação da COHAB e seus rebatimentos no espaço urbano. O último sub-item, de título "Reconhecendo o cortiço em áreas centrais enquanto modalidade de habitação popular atual", aborda as habitações coletivas precárias na área central de Campinas a partir de levantamentos executados durante a pesquisa de campo, e traz a caracterização do perímetro de estudo e alguns apontamentos em relação às habitações coletivas populares.

Por fim, no terceiro capítulo, intitulado "Habitação coletiva popular na área central de Campinas - características e conflitos", organizamos, nos dois primeiros sub-itens, as informações obtidas através da pesquisa de campo, da coleta de depoimentos com moradores e freqüentadores da área pesquisada, do acervo 
iconográfico elaborado, visando caracterizar as habitações coletivas populares existentes na área central de Campinas, quanto aos aspectos físicos e às formas de ocupação dos mesmos. No terceiro sub-item, intitulado "Conflitos da moradia", organizamos os depoimentos coletados, de forma a apontar os conflitos, as regras internas estabelecidas e as perspectivas e principais anseios desta população. $O$ último sub-item destaca as ações recentes promovidas pelo poder público local, no reconhecimento e enfrentamento da problemática habitacional que se apresenta, então, sob a forma de cortiços, hotéis e pensões, na área central de Campinas.

A dissertação se propõe a contribuir para um maior conhecimento da habitação coletiva precária existente na área central de Campinas, em termos de suas diversas características espaciais e organizacionais, além de colaborar para uma maior inserção da referida cidade nos debates acerca das novas tendências de configuração dos centros de grandes cidades brasileiras. 


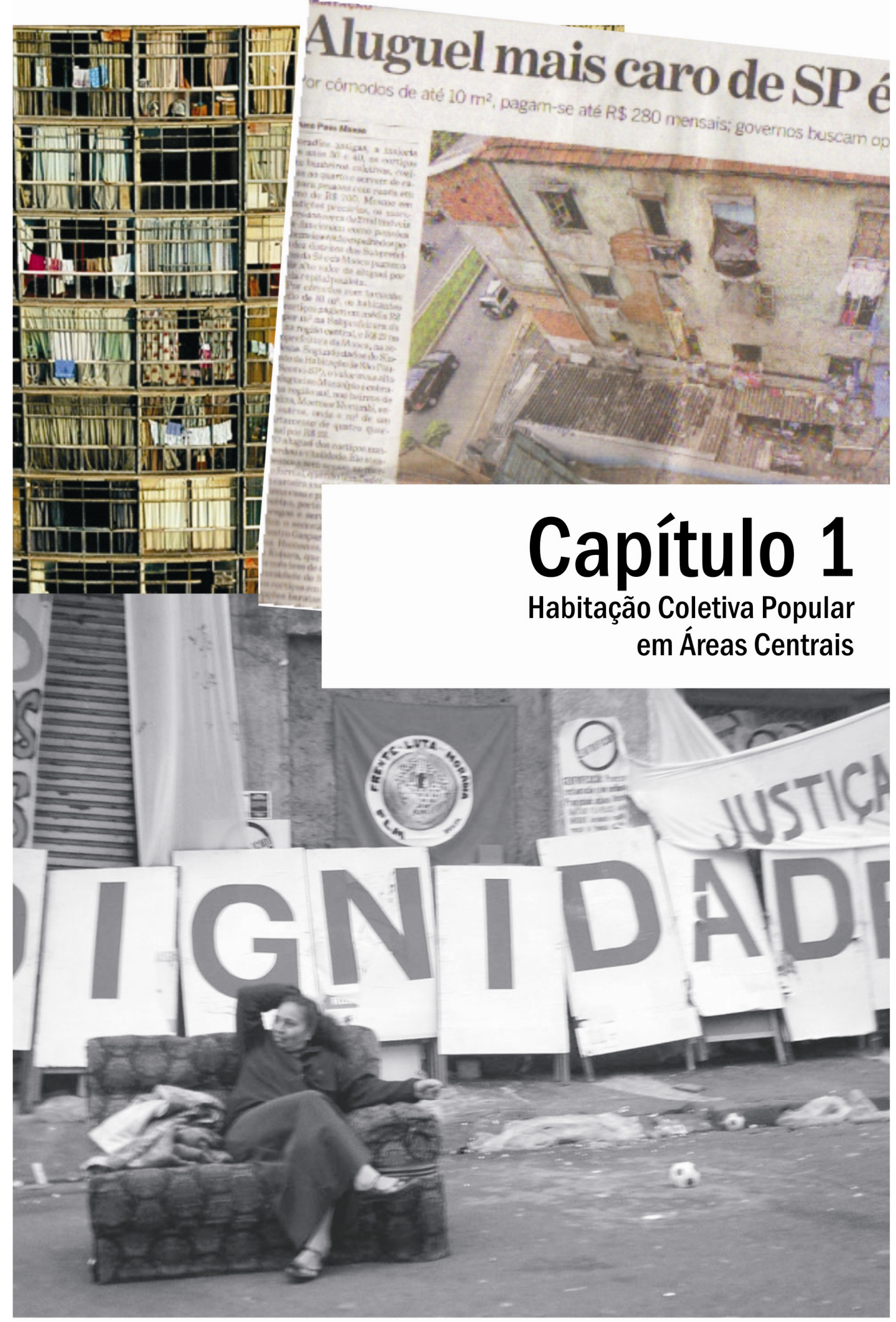




\title{
1.1. A moradia popular - origem e conceituação
}

Os cortiços representam um segmento de moradias que compõe, no quadro da pobreza urbana, uma de suas modalidades mais antigas. A origem da palavra se liga à idéia de congestionamento: "caixa cilíndrica de cortiça na qual as abelhas fabricam mel e cera" (FERREIRA, 1988); "a moradia das abelhas caracterizada pela sucessão de alvéolos de mesmo formato e tamanho" (LEMOS, 1998: p.10). Ao longo dos anos, várias denominações, que denotavam sua precariedade, foram associadas à palavra "cortiço". Entre as mais usadas estão: "casa de cômodo", "estância", "avenida", "zungu", "pensão", "hotel", "hospedaria", "vila", "quintal", "estalagem" e "fileira de quartos ao longo de um corredor". Outra expressão utilizada - "cabeça de porco" - foi o nome da mais famosa habitação coletiva do Rio de Janeiro em fins do século XIX. (VAZ, 1985: p.242). Segundo Lemos,

[...] fizeram-se às escondidas, em quaisquer nesgas de terrenos livres ou nos miolos de quarteirões, nos fundos de extensos quintais, milhares de aposentos de porta e janela enfileirados em conjuntos, às vezes, de grande número de unidades. Em geral, uma passagem central de dois a três metros de largura separando os quartos em correnteza e, nos fundos, uma pequena praça para as latrinas e os tanques, onde houvesse água corrente, pois houve cortiços providos tão somente de fossas negras, sendo a água das refeições buscada em fontes, ribeirinhos ou cisternas próximas. Águas servidas correndo a céu aberto (LEMOS, 1998: p.10).

Os cortiços já existiam antes mesmo da sociedade entendê-los como um problema sanitário e social, proporcionando aluguéis compensadores à pragmáticos empreendedores imobiliários. Do ponto de vista da saúde, as dimensões reduzidas, o pouco arejamento e a escassa iluminação, o amontoamento de pessoas e coisas em espaços confinados, eram entendidos como condicionantes de um meio propício à geração de moléstias. Conforme Correia,

\begin{abstract}
nos relatos do caos que, para observadores da época, presidia a vida num cortiço acrescentava-se uma estreita ligação entre o domínio da moradia e o do trabalho, através de atividades de criação e pequenas manufaturas, lojas e oficinas. Essas imagens de sujeira, aglomeração intensa e misturas perigosas traduziam um ambiente responsabilizado por uma pretensa degradação e desmoralização dos trabalhadores (CORREIA, 2004: p. 05).
\end{abstract}

Algumas das mais importantes cidades brasileiras tiveram sua história marcada pela presença deste tipo habitacional, que se apresentou como alternativa em meio ao processo de estruturação urbana de finais do século XIX. A partir do cenário 
apresentado pela cidade de São Paulo, do final do século XIX até a década de 1920, Carlos A. C. Lemos $(1985,1998)$ analisa a legislação relativa às habitações populares, e como as mesmas reconhecem e definem em seu escopo de regulamentações os cortiços paulistanos.

Conforme Lemos (1998: p.11-12), nesta cidade, um dos primeiros a se manifestar sobre a questão foi o médico Dr. Eulálio da Costa Carvalho, em novembro de 1885. Sugeria, em documento apresentado à Câmara, a extinção dos cortiços já existentes e a total proibição de novas construções da modalidade. Atentava para a incontrolável proliferação que iria

[...] concorrer para o sacrifício da saúde e das vidas de muitos indivíduos habitantes deles, das suas vizinhanças e em geral da cidade, os quais não raras vezes serão atacados por moléstias originadas pela acumulação de indivíduos nessas casas mantidas em completo desaceio (apud LEMOS, 1998: p. 12).

O engenheiro Luís César do Amaral Gama, solicitado no mesmo ano a dar pareceres técnicos sobre a questão, também se manifestou contra a tolerância aos cortiços, de maneira ainda mais radical.

[...] acho que seria de suma conveniência a sua extinção, o que conseguiria em pouco tempo, proibindo a construção de novos prédios para esse fim destinados e não se consentindo que sejam restaurados os que existem e que porventura tenham de ser conservados como tais. Por este meio acredito que em pouco tempo terão desaparecidos estes perniciosos edifícios, cuja fiscalização é dificilmente exercida por parte da Higiene Pública (apud LEMOS, 1985, p. 61).

No entanto, em 1886, tanto o Código de Posturas como o Padrão Municipal, apesar de não definirem o que seja cortiço e englobarem essa modalidade de habitação junto às casas operárias e cubículos, traziam regulamentações para a construção dos mesmos ${ }^{14}$, tolerando este tipo de habitação em zonas suburbanas, isto é, nas áreas industriais além do rio Tamanduateí, ao longo da estrada de ferro e na zona rural. Nestes locais, a tolerância a esse tipo habitacional ficava a cargo dos fiscais da Câmara e das duvidosas negociações possíveis com os interessados.

\footnotetext{
${ }^{14}$ Aceitando, por exemplo, um poço ou torneira com água e um tanque de lavagem para cada seis habitações no máximo e uma latrina para cada grupo de duas habitações. O Código de Posturas ainda regulamentava dimensionamentos. Os terrenos destinados a cortiços não podiam ter menos de $15 \mathrm{~m}$ de frente; e rua interna, nunca com menos de $5 \mathrm{~m}$ de largura; cada unidade habitacional, cômodo único, nunca menos de $5 \mathrm{~m}^{2}$, sempre provido de porta e janela; pé-direito mínimo de 4,5 m, porão, ou elevação, de $20 \mathrm{~cm}$ acima do nível do solo (LEMOS, 1998: p. 13).
} 
Ainda assim, o mesmo engenheiro citado acima, encabeça uma lista de técnicos encarregados de fazer um amplo relatório sobre a questão dos cortiços e casas de cômodos, pois tudo indicava que a proliferação dessas habitações havia agravado questões de saúde pública e de ordem social, sobretudo por surgirem em grande número dentro do perímetro urbano, dito "do comércio", justamente onde não eram autorizadas pelo código. O relatório final com os resultados deste levantamento foi apresentado à Câmara Municipal pelo intendente Cezário Ramalho da Silva em 1893, com o nome "Relatório de Commissão de Exame e Inspecção das Habitações Operárias e Cortiços no Districto de Santa Ephigênia"15.

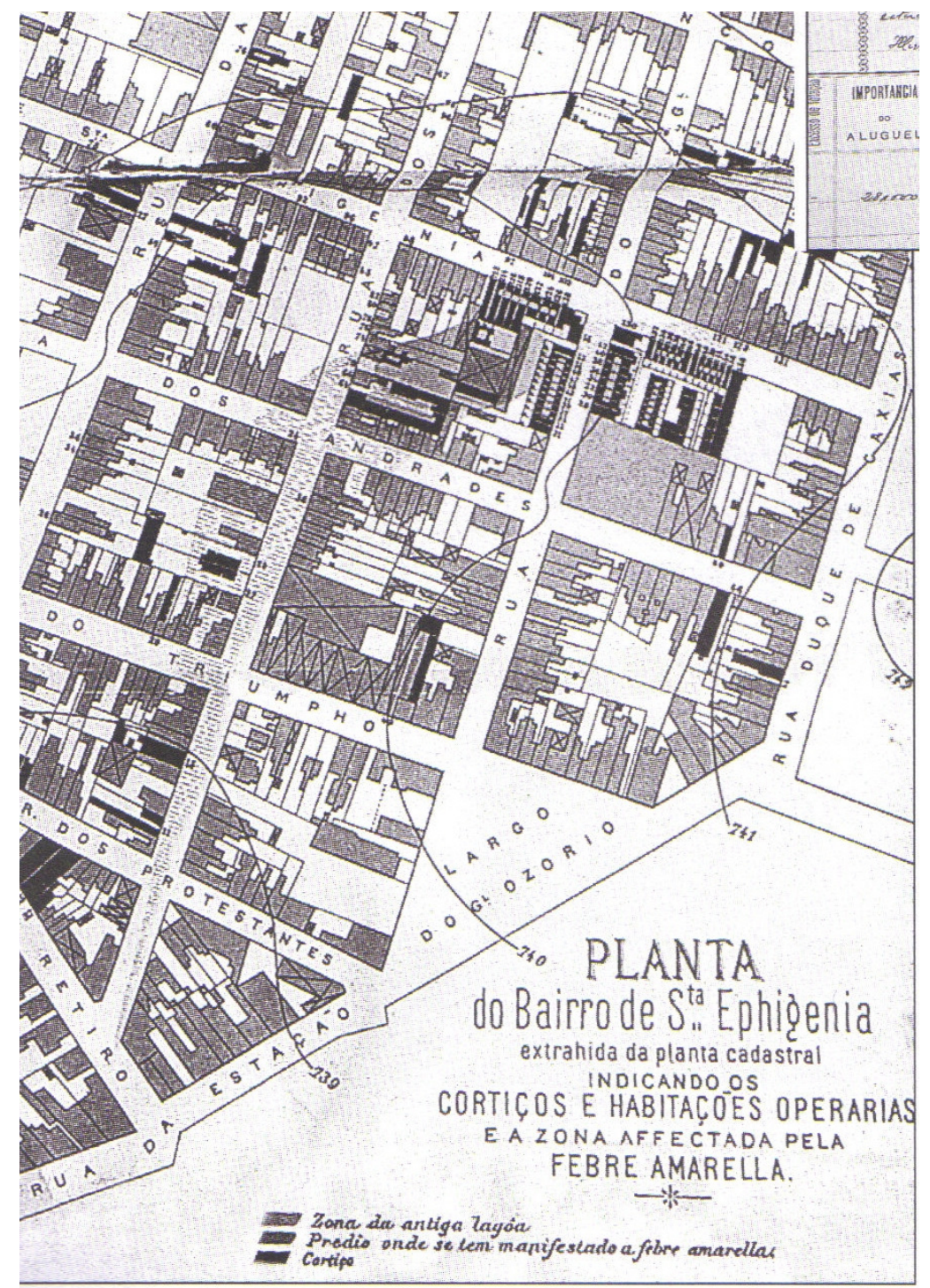

Figura 1 - Planta de um trecho do bairro Santa Ifigênia com a indicação dos cortiços Fonte: Relatório de Commissão de Exame e Inspecção das Habitações Operárias e Cortiços no Districto de Santa Ephigênia (apud BONDUKI, 2004: p.58)

15 Sobre o Relatório ver: Rolnik (1981), Kowarick (1988), Sampaio (1993), Bonduki (1994) e Correia (2004). 
Os cortiços analisados estavam associados à formação dos bairros fabris do final do século XIX e das primeiras décadas do século XX e eram, principalmente, ocupados pela população operária. Especificamente se ateve à paróquia de Santa Ifigênia, onde havia eclodido grave epidemia de febre amarela, analisando e descrevendo em profundidade as habitações existentes e a falta de higiene daqueles "habitáculos imundos, escuros e sem ventilação" (LEMOS, 1998: p.13). A comissão de técnicos apontou como única solução a desapropriação e imediata demolição dos daqueles imóveis infectos e posterior construção de casas salubres, depois de aterrados e nivelados os terrenos. Ao mesmo tempo, enumerou vários bairros praticamente desabitados e próximos das linhas do trem onde poderiam ser construídas "vilas operárias", de acordo com projetos apresentados.

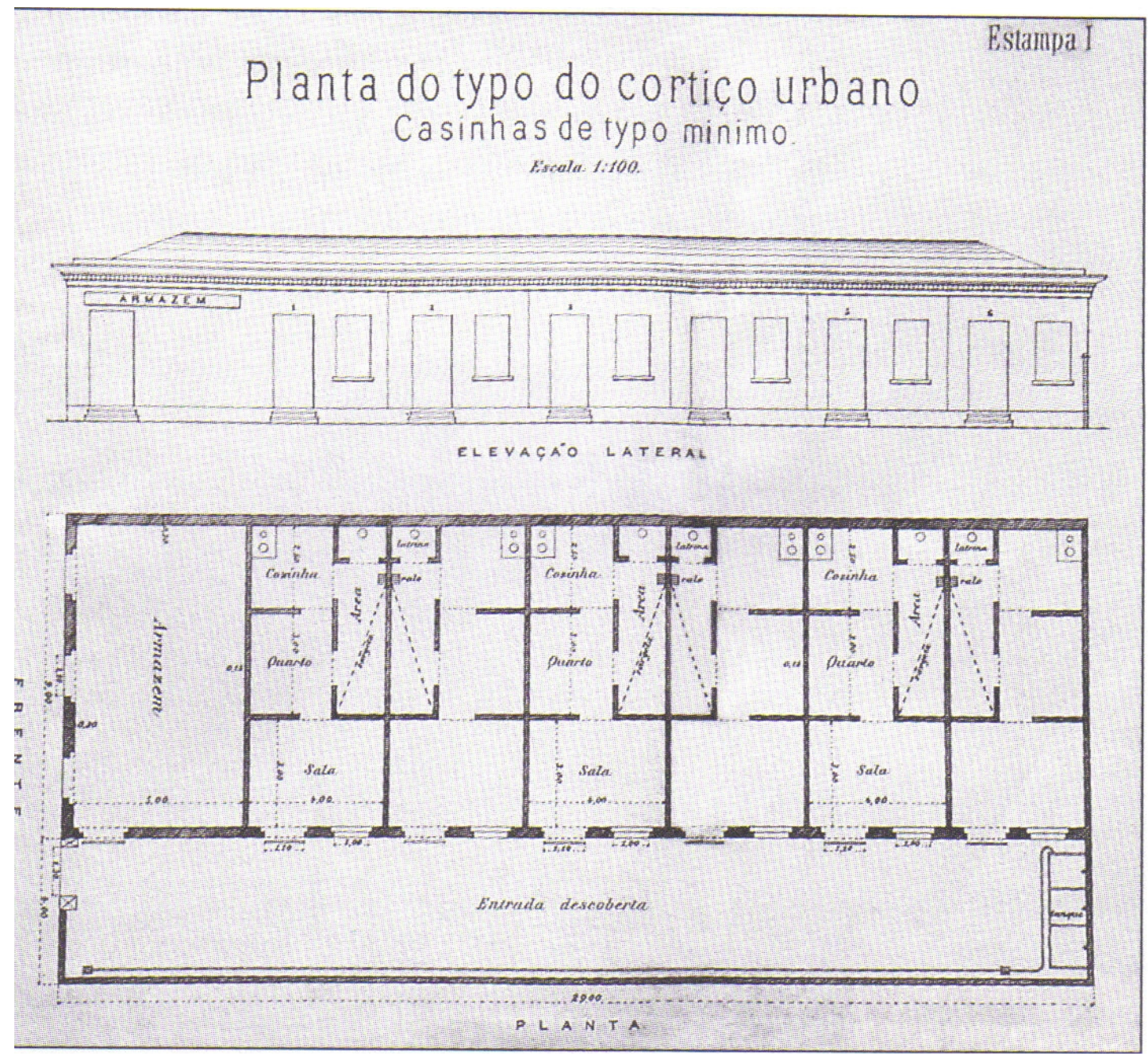

Figura 2 - Planta tipo do modelo de moradia operária proposto pela Comissão de Exame e Inspeção de Cortiços, em 1893.

Fonte: BONDUKI (2004: p.59) 
Argumenta-se que,

[...] é preciso cuidar da unidade urbana, a habitação, não já da habitação privada, mas daquela onde se acumula a classe pobre, a estalagem onde pulula a população operária, o cortiço que vulgarmente se chamam essas construções acanhadas, insalubres, repulsivas algumas, onde as forças vivas de trabalho se ajuntam em desmedida, fustigadas pela dificuldade de viver, numa quase promiscuidade que a economia the impõe, as que a higiene repele. [...] A higiene pública pode e deve em certos casos suprimir garantias, com a condição, porém, de ser judiciosa, sincera e eficaz. Com as leis da higiene na mão, o poder público manda demolir, retocar e reformar o que não pode permanecer sem corretivo; faz desaparecer utilidades, cria outras e nem sempre é obrigado a indenizar o que houver de condenar muita vez (Relatório de Commissão de Exame e Inspecção das Habitações Operárias e Cortiços no Districto de Santa Ephigênia. In: LEMOS, 1998: p.21 e 22).

Para Lemos, esse relatório é merece destaque porque, pela primeira vez, é levantada a questão da unidade urbana, isto é, da casa familiar. Apresenta-se, em meio a inúmeras pesquisas sobre cortiços no município - tanto estudos de caráter etnográfico como investigações do tipo cadastral e censitário -, como uma das primeiras informações sistematizadas sobre a existência de cortiço na cidade de São Paulo. Aponta e localiza as diferentes tipologias encontradas naquele bairro, rua à rua. Os tipos encontrados foram classificados como: "Cortiço de quintal", que ocupava o centro da quadra, com acesso por pequeno corredor; "Cortiço-casinha", que se tratava de uma construção independente, de frente para a rua, confundida com pensão; "Casa de cômodos", que era o sobrado com várias divisões internas; "Cortiços improvisados", que se referiam à ocupação precária de áreas livres, no fundo de casas, depósitos, bares, etc.; "Cortiço-avenida", que eram cômodos ou mesmo casinhas, alinhados ao longo de rua interna e abrindo-se para ela, com acesso comum, por portão que dá para a rua; e ainda o "Hotel-cortiço", que funcionava como restaurante durante o dia, e à noite, era utilizado para dormir.

O relatório referia-se aos cortiços como "antros [...] onde fenece a saúde mais robusta e onde o operário incauto, à busca de uma economia ilusória e fatal, encontra quase sempre os germes que o dizimam" (Relatório da Comissão de Exame e Inspecção das habitações Operárias e Cortiços do Districto de Santa Ephigênia, 1893: p. 54).

Apesar de serem objetos arquitetônicos de formas diferentes, eram iguais em sua essência, não apenas por serem indistintamente chamados de cortiços, e por 
conterem os mesmos elementos de uso coletivo - w.c., banheiro, tanque, pátio ou corredor -, mas também por serem todos produtos resultantes de um mesmo sistema de produção de moradias. Neste sistema, proprietários podiam ceder seus imóveis (térreos, sobrados, quintais, terrenos) a terceiros que investiam pequenas economias na construção de casinhas ou na subdivisão das edificações existentes. Em outras casas - como exemplificado no livro "O Cortiço", de Aluísio de Azevedo, o próprio proprietário do imóvel edificava e administrava o cortiço. Os aluguéis eram considerados baixos e os rendimentos bastante compensadores.
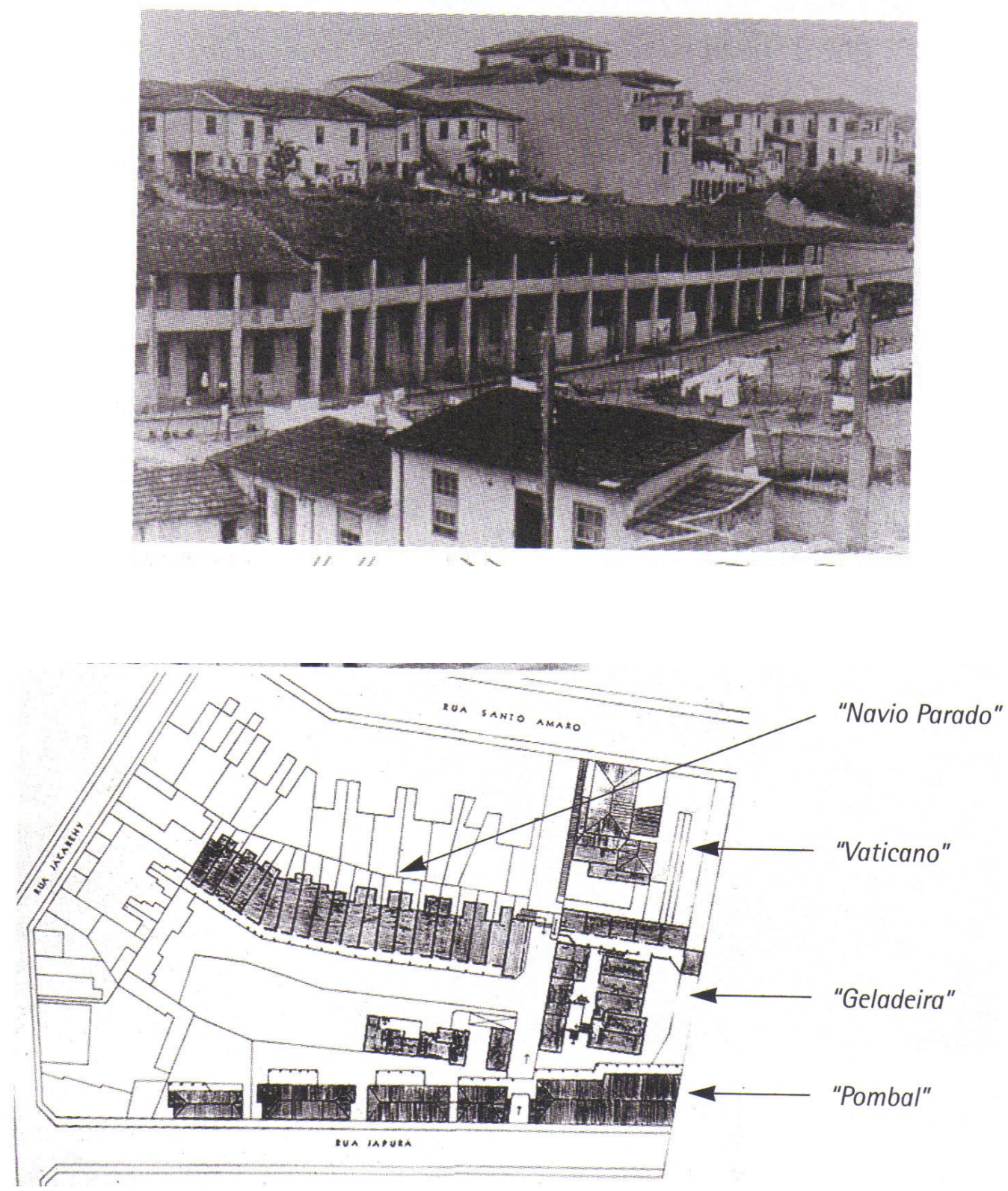

Figuras 3 e 4 - Vista geral e planta do complexo de cortiços formado pelo "Navio Parado", "Vaticano", “Geladeira" e "Pombal”, no bairro Bexiga, em São Paulo. Forte símbolo da produção rentista em São Paulo da década de 1920.

Fonte: BONDUKI (2004, p.55) 
A existência de excedentes econômicos nas mãos de investidores de diversos portes, a restrita capacidade de aplicação no setor industrial, a expansão e retração cíclica da cafeicultura, a valorização imobiliária e a grande demanda por habitações em São Paulo, os incentivos fiscais e a inexistência de controles estatais dos valores dos aluguéis - tudo isso tornou o investimento em moradias de aluguel bastante atraente durante a Primeira República. [...] Embora alugados a valores absolutos mais baixos, acessíveis aos salários dos trabalhadores, a soma dos aluguéis dos vários cômodos de um cortiço rendia mais que a de uma vila de casas unifamiliares (BONDUKI, 2004: p.45 e 54).

O Código Sanitário Estadual promulgado no ano seguinte, em 1894, certamente influenciado pelas conclusões dos técnicos responsáveis pelo Relatório de Santa Ephigênia, proíbe a construção de cortiços e sugere a extinção dos existentes. Também menciona, pela primeira vez, grandes casas subdivididas entre várias famílias, as quais denomina "casas de cômodos", embora no linguajar comum fossem conhecidas como cortiços. Tratava-se da apropriação e aproveitamento, por parte do proletariado, dos velhos casarões abandonados pela elite que, por sua vez, passava a morar em arrabaldes com ruas largas de belas perspectivas.

Somente em 1896, a legislação municipal vem tentar uma definição de cortiço. A Lei n. 286, daquele ano, coloca em seu artigo 13: "entende-se por cortiço o conjunto de duas ou mais habitações que se comuniquem com as ruas públicas por uma ou mais entradas comuns para servir de residências a mais de uma família". E trata também da nova modalidade de apropriação do espaço residencial existente: "compreende-se também como cubículo de cortiços ou cômodos de casas que não sejam cortiços, mas que estejam divididos em diferentes fogões e os que lhe forem acrescidos nas mesmas condições". Percebe-se uma caracterização da nova modalidade de cortiço: instalações sanitárias comuns a várias famílias e cada qual com o seu fogão particular no casarão subdividido.

Anos depois, o decreto estadual 2.141, de 1911, que cria o Serviço Sanitário do Estado, não menciona a palavra "cortiço" e sim "habitações coletivas", definindo-as como: "as casas que abrigarem ou servirem de dormitório, ainda que temporário, a várias famílias ou a muitas pessoas de famílias diferentes" (art. 293). Ainda exige que haja no mínimo uma latrina para cada grupo de vinte indivíduos e, também banheiros e lavabos indispensáveis.

Promulgado em 1918, vigorando praticamente até a década de 1940, o Código Sanitário Estadual igualmente trata dos cortiços enquanto "habitações coletivas". 
Alguns autores revelam que o uso do termo "habitações coletivas" se dava como mecanismo de disfarce daquela modalidade constrangedora de habitação, cujas condições de habitabilidade acabavam por ter que serem tratadas pela legislação.

O Código de Obras Artur Saboya, Lei Municipal n. 3.427 de 1929, estabelece dois tipos de habitação coletiva: os hotéis e os prédios de apartamentos. As outras modalidades de moradia compartilhada por mais de uma família seriam clandestinas ${ }^{16}$. As regulamentações dirigidas para "vilas operárias ${ }^{17 "}$ vigentes até então foram revogadas, vigorando somente novas regras para as "casas populares".

Lemos indica que membros da elite paulistana possuíam cortiços na área de Santa Ifigênia ${ }^{18}$, como forma de suplementar suas rendas, como o professor Brasílio Machado, Dr. Carmo Cintra, o grande fazendeiro de café José de Amaral Campos, Antônio Cândido da Costa Aguiar e outros. Chama atenção para o nome de Carlos Girardi, possuidor de 9 cortiços, com 289 inquilinos em seus cubículos. No total, eram 2.136 inquilinos, formando 380 famílias, resultando numa média de 5,62 pessoas por família (LEMOS, 1998: p.17). Por um lado, fica evidente os interesses imobiliários presentes nessa questão. Por outro, expressam-se preocupações de ordem sanitária, moral e social, associadas à estigmatização e combate ao cortiço. Segundo Correia,

\begin{abstract}
em termos morais, a casa do pobre era vista como ambiente promíscuo e embrutecedor, onde se originavam a imoralidade, os desvios, a mendicância e a revolta. Seus amontoamentos, misturas e sujeira eram vistos como absolutamente incompatíveis com uma vida familiar sadia e regrada. Por não ser um ambiente acolhedor, era responsabilizada por atirar seus oradores às ruas, aos bares e bordéis, onde se entregavam aos vícios, devassidão, ócio, enfim, a toda uma série de atividades marginais à sociedade do trabalho, que então a burguesia estava empenhada em construir (2004: p.8-9).
\end{abstract}

No estado de São Paulo, outras duas cidades merecem destaque: Campinas ${ }^{19}$ e Santos. Na cidade de Santos, sempre dependente das condições econômicas do planalto e das disposições do Estado, existiu um longo ostracismo até o século XIX, onde, no ano de 1884, a cidade vive um grande movimento de expansão, fruto da economia cafeeira, ultrapassando a cidade de Rio de Janeiro em volume de café

\footnotetext{
${ }^{16}$ O Estado cria a clandestinidade, uma vez que reconhece a existência destas ditas "outras modalidades de moradia", e não as abarca enquanto objeto de regulamentação ou de políticas públicas.

17 Lembrando que as mesmas toleravam instalações sanitárias comuns, caracterizando cortiços disfarçados.

${ }^{18}$ Conforme levantamento realizado e apresentado no Relatório de Comissão de Exame e Inspeção das Habitações Operárias e Cortiços no Distrito de Santa Ephigênia.

${ }_{19}$ A cidade de Campinas será tratado em capítulo específico por se tratar do objeto de estudo desta dissertação.
} 
exportado (LANNA, 1998: p.67). A expansão da cultura do café colocou, de forma urgente, uma série de transformações das relações de trabalho, além de incrementar o crescimento das cidades e demandar uma crescente rede de atividades de comercialização e exportação, todas de caráter urbano. As elites começaram a fixar residência nos centros urbanos demandando toda uma rede de serviços e melhoramentos urbanos em larga medida implementados pelo capital estrangeiro.

A ligação ferroviária Santos - São Paulo foi concluída em 1868 e marcou o início de um novo tempo. A remodelação do porto, quase 25 anos depois, associada a uma intensa renovação urbana dirigida por sanitaristas, fechou este momento de formação da cidade. Esta associação "ferrovia - porto - sanitarismo", transformando Santos em monopolizador de todo o tráfego do planalto, demarcou, em larga escala, suas possibilidades de expansão e seus limites de crescimento e dependência em relação ao planalto e à cidade de São Paulo. Esse crescimento quantitativo ${ }^{20} \mathrm{e}$ qualitativo procurava sempre romper com o acanhamento de cidade colonial, através de uma série de intervenções públicas e privadas, como demolições, alargamento de ruas, políticas de saneamento e disciplinarização da população trabalhadora, novas formas de lazer, e outros elementos, que tinham por objetivo a constituição de uma cidade bela, higienizada, onde homens e mercadorias pudessem circular livremente, fazendo dela uma cidade dita moderna.

Os obstáculos a esse devir foram, sistematicamente, alvo de políticas públicas federais, estaduais e municipais. A cidade era conhecida por sua pestilência, pelos seus altos índices de mortalidade, decorrentes, sobretudo, das epidemias que a atingiam violenta e repetidamente. A constituição dessa cidade moderna passaria, necessariamente, pelo equacionamento da questão da salubridade. Foi sob o manto da necessidade e da imperiosidade técnica que se promoveram reformas urbanas e no sistema portuário, que implicaram, por um lado, no efetivo saneamento da cidade e, por outro, na definição dos mecanismos de exclusão social.

A classe trabalhadora local era composta, sobretudo por imigrantes, principalmente portugueses e espanhóis, pelos ex-escravos aí acoutados aos milhares nos anos finais da escravidão ${ }^{21}$ e por uma legião de desenraizados que percorriam o

${ }^{20}$ Segundo Lanna (1998), Santos cresceu 223\% e São Paulo 403\% no período de 1886 a 1900 . Não se pode esquecer que neste período Santos foi palco de inúmeras epidemias. Para se ter uma idéia, em 1900 sua população era de cerca de 50 mil pessoas, ainda que entre 1891 a 1895 morreram só de febre amarela cerca de 5.740 pessoas.

${ }^{21}$ Santos terá uma participação decisiva no processo de abolição da escravatura. Em meados dos anos 1880 é considerada cidade livre, para onde fugiam milhares de escravos que abandonando as fazendas 
país em busca de oportunidades de trabalho e integração ao mundo capitalista em expansão.

Como controlar estes grupos instáveis, de tradições e trajetórias diferentes? Como fazer deles trabalhadores morigerados e confiáveis? Eram questões fundamentais para as elites naquele momento. Concomitantemente, estava colocada a necessidade de reformulação do espaço urbano. Higienizar e embelezar são ações que marcaram as intervenções urbanas neste período. Foram políticas atuando em diferentes aspectos da formação da cidade e da sociedade, constituindo uma teia que modernizaria os espaços e disciplinaria os usos. Nesta perspectiva, a atuação sobre as condições de habitação, sobre as maneiras de morar, fazia parte desta estratégia mais global e não poderia ser, sem ela, compreendida.

Várias são as descrições sobre a cidade de Santos, no final do século XIX, e todas elas acabam enfatizando o grave problema da salubridade, que impedia, ou pelo menos limitava enormemente as possibilidades de expansão e desenvolvimento da cidade. Alguns graves obstáculos começaram a exigir algum tipo de eficiência na solução dos problemas desta cidade. A necessidade de um porto capaz de escoar a produção cafeeira de forma mais rápida; a agilização na chegada dos imigrantes subvencionados que se dirigiam para as fazendas do interior da província e das mercadorias importadas para suprir demandas urbanas; além das epidemias, cada vez mais violentas. O presidente do Estado, em 1892, alertava para a necessidade de medidas saneadoras em Santos, porque as epidemias "perturbam a economia do Estado, ameaçam a comunicação com o exterior e expõem o território paulista à invasão de febre amarela" ${ }^{22}$.

O porto cresceu, "fechando-se" para a cidade. Tal fechamento era fisicamente caracterizado pelas muralhas, portões e rígidos controles tanto ao acesso quanto aos ritmos das várias turmas de trabalhadores aí envolvidos. As transformações dos serviços portuários vieram interligadas com mudanças, também radicais, no quadro urbano mais global. Implantou-se uma política de saneamento da cidade, de

de café para lá se dirigiam em busca de liberdade. Mas não se tratavam apenas de interesses humanitários. Outros impulsos orientavam a atitude de pelo menos parte da população local. Tratava-se da questão da captação e organização de trabalhadores para suprir as crescentes necessidades locais, fruto da expansão das atividades comerciais e portuárias da cidade. Estes escravos fugidos eram conduzidos para um local denominado Quilombo do Jabaquara, que fora criado por comerciantes locais no ano de 1882, e tinha como chefe um liberto de nome Quintino de Lacerda. Os negros aí acoutados participavam de uma série de atividades como trabalhadores livres: carroceiros, carregadores de lenha, fazedores de objetos de palha e roceiros para abastecer em parte as necessidades da cidade (LANNA, 1998).

${ }_{22}$ Mensagem dirigida ao Congresso Legislativo de São Paulo pelo vice-presidente do Estado Dr. José Alves de Cerqueira César no dia 7 de abril de 1892. São Paulo, 1892, p. 6 (apud LANNA, 1998: p.73) 
desobstrução e de ampliação de espaços, caracterizada pela abertura de largas avenidas, praças, espaços para a circulação, substituindo as vielas tortuosas, não alinhadas. Necessitava-se criar novos modos de morar, trabalhar, fluir, adequados à modernidade que se buscava implementar.

O processo de saneamento da cidade foi encampado e desenvolvido pelo governo do estado, através de sua Comissão Sanitária. Mais uma vez, a autonomia da municipalidade foi ferida em nome da urgência e eficiência necessárias nestas transformações. Nas tensões entre esses interesses, as (im)posições da Comissão Sanitária acabaram sempre por prevalecer.

Álvaro Guilherme, médico e diretor desta comissão, denunciou o corpo médico de Santos por não ter auxiliado, pelo menos nos primeiros tempos, "porquanto as notificações das doenças contagiosas eram feitas quase sempre tardiamente $e$ algumas vezes esquecidas. Como a população temia a remoção para os hospitais e, mais ainda, as desinfecções, os médicos não notificavam o fato à Sanitária" (apud LANNA, 1998: p.75). Saturnino de Brito, engenheiro sanitarista responsável pela construção dos canais de saneamento e autor de uma planta geral para a cidade, encontrou sérias resistências ao seu projeto, implementado de forma bastante abrangente. Uma polêmica com a Câmara Municipal foi travada em relação à planta geral.

A população reagiu de várias formas: negou a vacinação obrigatória, o isolamento dos doentes, a transferência de moradia, a perda de espaços de lazer e o controle sobre seu trabalho. De pequenas resistências cotidianas à greves, suas manifestações foram conseqüências da estratégia de mudança que a afetou, mas não a incluiu.

A política de saneamento que começou a ser implementada em Santos, pela Comissão Sanitária do governo estadual, em 1893, tinha em relação à questão da habitação uma linha mestra - impedir o adensamento. Em outras palavras, eliminar os cortiços da área central da cidade, onde a preocupação com as condições de vida da classe operária era problema que pouca atenção recebia. Ao se definir pela demolição ou desocupação das habitações dos trabalhadores não se pensava em onde alojá-los. Isso não era problema da Comissão Sanitária. Em geral, num movimento de expansão das fronteiras urbanas eles iriam recolocar os mesmos padrões de habitação e precariedade, só que longe das áreas de maior visibilidade. 
Se os cortiços eram a forma característica de habitação popular nas grandes cidades brasileiras deste período, os de Santos primavam pela abundância e precariedade, constituindo a fortuna de alguns, os singelos meios de sobrevivência de outros e as péssimas condições de vida da imensa maioria da classe trabalhadora.

Os cortiços eram construídos nos quintais das casas, ou via sublocação de quartos e porões. A inexistência de banheiros, ou mesmo de latrinas era uma constante. Os dejetos eram jogados nesses mesmos quintais ou em terrenos baldios fronteiriços às habitações. Uma descrição, das muitas existentes, expressa bem a idéia do que eram estes locais de moradia:

[...] O quintal de uma padaria e refinação de açúcar. Nesse terreno, um lodaçal negro e infecto, onde partiam lenha para o consumo do estabelecimento, havia um cortiço baixo de meia água, coberto com telha de zinco, igual a muitos outros espalhados pela podridão da urbe. Ali naquela área, em camaradagem (os habitantes eram em sua maioria estivadores), ou antes, suportando-se, [...] comendo no mesmo prato imundo restos de cozinha, o gato da padaria e grandes ratazanas, [...] da janela víamos serem retirados dos telheiros de zinco, que não passava disso o miserável e apertado cortiço, os doentes da febre amarela... que seus piedosos companheiros para ali carregavam para que tomassem um pouco de ar e que ali mesmo víamos morrer alguns momentos depois, e que ficavam se decompondo a espera do carro fúnebre (CASTAN, 1924, p.99-100).

Havia uma superposição de funções e coexistência de grupos distintos nos mesmos espaços. Em termos quantitativos, os dados são surpreendentes: em 1891, foram registrados "771 cortiços dos quais 478 considerados em mau estado, quando todos eles não tinham água, nem esgotos, eram baixos, acanhados, de solo desprotegido, construídos com os materiais menos apropriados" (GUILHERME, Álvaro, apud LANNA, 1998: p.76). Além disso, havia cocheiras onde habitavam homens e animais. Muitos trabalhadores ainda moravam junto aos locais de trabalho, submetendo-se a uma jornada de trabalho de 14 horas por dia.

Era um armazém de café. No térreo o depósito da sacaria, no primeiro andar o escritório. Abriram ao fundo uma porta de madeira, entraram por um corredor ainda mais escuro e chegaram ao espaçoso quarto em que terminava o sobrado. Era tão escuro que mesmo de dia precisava-se de uma vela. [...] Era uma caixa quadrada de teto alto, cercada por paredes que deviam ser espessas e úmidas, tão úmidas que os cantos pareciam esverdeados de limo. O soalho de tábuas largas, mal juntas, com buraco de ratos (SCHIMIDT, 1941: p.150-151). 
Ficava evidente a ausência de elementos considerados fundamentais para a habitação julgada higiênica pelas padrões da época - cozinha, banheiro, ventilação adequada, divisão de funções. Era julgada promíscua porque era compartilhada com outros colegas de trabalho e estranhos. As instituições, ao taxar seus moradores como vagabundos e perigosos, elementos nocivos à formação da sociedade civilizada, relegaram-os ao espaço da exclusão e da marginalidade, objetos de intervenção sempre de cunho repressivo, seja policial ou sanitário.

A ocupação da beira-mar e os primeiros loteamentos ofereceram possibilidades de residência em locais aprazíveis para quem tinha condições. Nesta época, alguns comerciantes mais abastados, que tinham se transferido para São Paulo com medo das pestes, retornaram a Santos. O crescimento dos órgãos públicos e o número de seus empregados também contribuiu de maneira decisiva para o aparecimento não só de bairros com características mais marcadamente residenciais, mas, sobretudo, das habitações unifamiliares. Observou-se então a separação do local de trabalho e moradia, comumente encontradas unidas no período anterior às políticas sanitárias.

O final dos anos 1880 marcou, por um lado, o início dessa ação de desadensamento do centro e, por outro lado, o aparecimento dos primeiros loteamentos previstos para a classe trabalhadora - loteamentos de iniciativa privada sempre associados à expansão do serviço de transportes urbanos e em geral explorados pelos proprietários dos terrenos. Evidentemente a população encortiçada nunca, ou muito raramente, teria condições financeiras de adquirir estes terrenos que seriam comprados por uma crescente camada urbana de servidores públicos e empregados qualificados da Companhia Docas de Santos.

As ações sanitaristas e de remodelação e embelezamento não atingiram somente os cortiços e habitações insalubres. Esse amplo processo, além de demolir, criava um novo espaço urbano - com espaços abertos, avenidas, jardins, largos e praças para a circulação de ar e disciplinarização e organização dos usos. Uma cidade para o progresso ${ }^{23}$. A idéia de uma planta geral que ordenasse a cidade existente e que previsse seu crescimento era peça fundamental na ação de Saturnino de Brito.

Revela a cidade como objeto técnico, mas também estético [...] Com o plano de saneamento, melhoramentos e extensão que Saturnino de Brito elabora e implanta em Santos, mesmo que não tendo sido realizado em todos os seus aspectos, não apenas temos a

\footnotetext{
${ }^{23}$ ANDRADE, W. (1989), trata especialmente no capitulo III, das demolições em geral encampadas pelo poder municipal, de três lugares centrais: a Praça Rui Barbosa e a da República e a Rua XV de Novembro.
} 
construção de uma cidade moderna, mas também a aplicação de princípios urbanísticos revolucionários para a época, onde o passado colonial da cidade desaparece em nome de um futuro marcado pela higiene e pelo progresso, que influenciará decisivamente o desenvolvimento do planejamento urbano no Brasil [...], a representação da cidade como organismo, e o resgate da dimensão estética (de uma natureza artificial) sem com isso comprometer a sua funcionalidade da cidade (ANDRADE, 1992: p.141/ 202/ 210).

A cidade e o porto se distanciavam. O saneamento definiu um novo espaço urbano privilegiado, à beira-mar. Entre este e a velha cidade, alguns quilômetros de terras livres, e após 1913, terras saudáveis, para serem devidamente incorporadas pela especulação imobiliária. A partir de 1913 - após a inauguração dos canais de saneamento projetados por Saturnino de Brito - a cidade foi higienizada, os cortiços de madeira dos quintais do centro banidos, a campanha sanitária dera resultados, e a cidade expandida, com seus aprazíveis canais e jardins à beira-mar, dividira-se entre o centro antigo, essencialmente comercial e remodelado com apuro, e uma área suburbana, das praias, com casas elegantes e belas avenidas.

Mas desse belo cartão postal estava excluída parte significativa da população. Desalojada, banida, destituída dos equipamentos urbanos que a cidade estava acabando de receber [...]. O mesmo processo que introduzia melhoramentos públicos elegia os excluídos destes benefícios (GAMBETA, 1984: p.25).

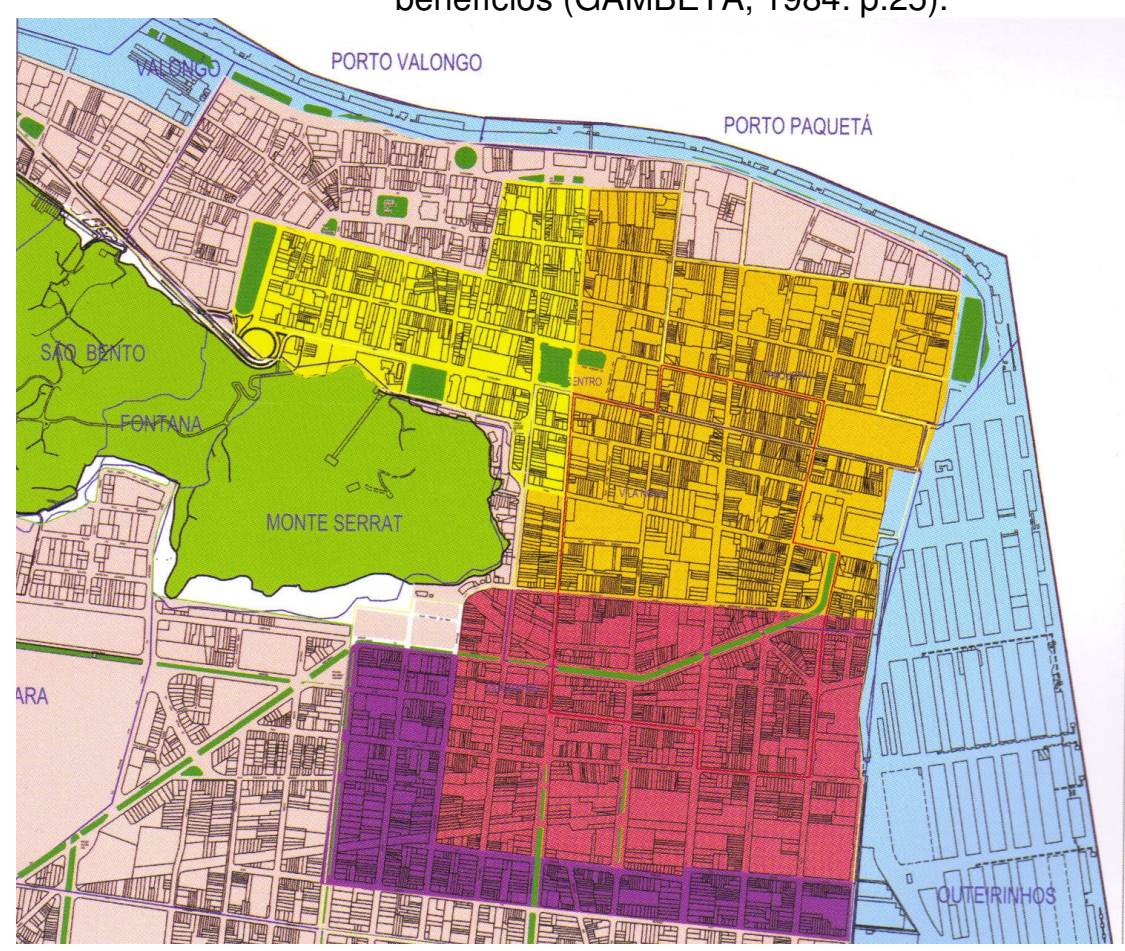

Figura 5 - Evolução da Ocupação de Domicílios encortiçados no município de Santos do século XIX ao ano 2000

Fonte: SÃO Paulo: CDHU-SEADE, 2002a: p.7 
No Rio de Janeiro - maior cidade do país em fins do século XIX, onde se concentrou o debate sobre a reforma da cidade e da moradia -, o engenheiro Luiz Raphael Vieira Souto, em 1886, expressava seu repúdio ao cortiço, "poderoso foco de infecção", "germe perene a todas as enfermidades", cuja sujeira, aglomeração e misturas lhe sugeriam a imagem de estábulos e pocilgas:

[...] aos cortiços não faltam unicamente ar e luz: a escassez de espaço. A ausência de distribuição racional e arranjos interiores; a péssima qualidade dos materiais de que são construídos; a falta absoluta de drenagem do solo e edifícios; a insuficiência d'água, latrinas e esgotos; a singular convivência que não raro estabelecem os inquilinos com galinhas e porcos; e mais que tudo a aglomeração de indivíduos, só comparável à dos animais nos estábulos, transformam esses tristes abrigos das classes proletárias da Capital do Império em repugnantes pocilgas, que não parecem habitações da pobreza laboriosa, porém antros de miséria e degradação. (SOUTO, 1886: p.23, apud CORREIA, 2004: p.7-8)

Sucediam-se as denúncias de médicos higienistas, relatórios de engenheiros sanitaristas, pareceres de comissões de notáveis e editoriais da imprensa apontando para as péssimas condições físicas das moradias (insalubridade, má distribuição dos espaços internos, falta de iluminação e ventilação, insuficiência e deficiências de instalações sanitárias), e conseqüente degradação da saúde da população moradora nessas condições, além da superlotação e a promiscuidade que as acompanhava.

Em relatório para o ministro da Justiça e Negócios Interiores, escrito em 1906, o engenheiro Everardo Backheuser expressava seus temores a este respeito:

E assim reunida, aglomerada, essa gente - trabalhadores, carroceiros, homens de ganho, catraieiros, caixeiros de bodegas, lavadeiras, costureiras de baixa freguesia, mulheres de vida reles, entopem as "casas de cômodos", velhos casarões de muitos andares, divididos e subdivididos por um sem número de tapumes de madeira, até nos vãos de telhados, entre a cobertura carcomida e o ferro carunchoso. Às vezes, nem as divisões de madeira; nada mais que sacos de aniagem estendidos verticalmente em septos, permitindo quase a vida comum, em uma promiscuidade de horroriza" (BACKHEUSER, 1906: p. 108, apud CORREIA, 2004: p. 9).

Neste combate às moradias insalubres destacaram-se certos agentes sociais: por um lado o Estado, atuando através da restrição à construção de novas moradias, da imposição de normas higiênicas e da intervenção direta (fechamento de cortiços); por outro os empresários do nascente setor imobiliário, que introduziriam novo padrão de edificação. Conforme Vaz, 
com o poder de erradicação de porta-vozes como empresários, engenheiros e médicos, 0 discurso de higiene disseminou a condenação das habitações populares coletivas (insalubres ou não), fazendo abstração das más condições de higiene que imperavam igualmente nas moradias não populares, nas fábricas, escolas, quartéis, etc. (VAZ, 1998: p.42).

Em vista da alegada deterioração física e moral das classes trabalhadoras, o Estado Imperial incentivou a construção de vilas de casas higiênicas e baratas para proletários e operários, dando concessões de favores a construtores. Estas concessões garantiam aos empresários o direito de desapropriação de prédios e terrenos necessários à realização de projetos, a isenção de impostos durante vários anos e das taxas de alfândega para importação de materiais de construção.

No Rio de Janeiro, as novas posturas municipais incentivaram a proliferação dos tipos intermediários entre habitações coletivas e vilas higiênicas: as avenidas que podem ser consideradas como estalagens higienizadas. Muitas surgiram da modernização de antigos cortiços que eram reformados ou tinham suas instalações melhoradas como no caso do romance de Aluísio de Azevedo, em que, depois de uma reforma, a Estalagem de São Romão se torna a Avenida São Romão (VAZ, 1998: p.43).

Vaz chama a atenção à afirmação consensual de que os pobres do Rio antigo viviam na sua maioria em cortiços. Os dados estatísticos indicam que apesar de cerca de $3 / 4$ da população ser considerada pobre, apenas uma parte desta camada popular habitava os cortiços. Com efeito, apesar da pouca confiabilidade dos dados disponíveis, há entre eles certa coerência, pois apontam para uma pequena, mas crescente parcela de moradores em habitações coletivas: 9,65\% da população em 1869, 11,72\% em 1888 (estatísticas higienistas); cerca de 17\% em 1890 (estimativa da construção civil); cerca de 20\% em 1891 (estimativa higienista); aproximadamente 25\% em 1890 (cálculos de estudos posteriores) (VAZ, 1985).

Coloca-se a questão: se os dados oficiais estimam em uma décima parte da população os moradores de cortiços, e se até as mais alarmistas estimativas apontam uma quarta parte da população nestas condições, onde moraria o restante dos pobres no Rio antigo? Há uma série de indícios que apontam para várias outras soluções de moradia - "alternativas não modernizadas, não reconhecidas, não contabilizadas e não controladas" (VAZ, 1998: p.46). Seriam estas: as tradicionais unidades trabalho/moradia, que ainda não haviam sido rompidas completamente pela 
modernização ${ }^{24}$; e quartos de aluguel, cuja oferta era recorrente em tempos de crise habitacional. Segundo Vaz (1998: p.47) "um mesmo sobrado podia ser em etapas diferentes 'casa de família' em que se alugavam quartos, uma casa de pensão, uma casa de cômodos ou até uma hospedaria. Nas hospedarias baratas, zungas ou casas de dormida alugavam-se camas, vagas ou esteiras (ou parte) por noite". Assim como os "quartos de alugar", outros espaços no interior de casas particulares foram utilizados para a moradia, como os sótãos e os porões. Esses vazios insalubres, resultantes de imposições higienistas que recomendavam elevar os compartimentos habitáveis do solo, foram ocupados para moradia. Com a difusão da cessão destes espaços, a municipalidade proibiu a residência nos porões e lojas em 1892. Há registros de subdivisão e aproveitamento de todas as dimensões das edificações, inclusive a altura. Há ainda notícias de aproveitamento de ruínas, vãos e cavernas nos morros.

Igualmente em Recife - onde o debate acerca da moradia também se fazia presente -, o engenheiro Umberto Gondim, em 1924, atribui o alto coeficiente de mortalidade da cidade "exclusivamente à falta de salubridade das habitações", exemplificando numa descrição do mocambo:

\begin{abstract}
Imagine uma grande área pantanosa, coberta de mangues, surgindo aqui e ali pequenas ilhas, umas esparsas, outras contínuas, formadas por escavações feitas em suas adjacências e nelas se elevado pequenas choupanas de taipa cobertas na sua maioria de folhas-deflandres, palhas de coqueiro, capim, etc. Outras vezes elas são construídas em terreno firme, mas de tal forma aglomeradas que dificilmente se distinguem ruas de vielas ou vice-versa. Essas casas de aspecto miserável, cujo piso é construído de barro socado, têm apenas duas entradas, uma na frente e outra na parte posterior, dando às vezes dificilmente acesso, devido às suas limitadas dimensões, aos seus infelizes ocupantes. Compõem-se geralmente de 3 compartimentos: sala, quarto e cozinha, nas piores condições de higiene, e abrigam na maior promiscuidade famílias compostas de 10 ou mais membros (GONDIM, 1925: p.17, apud CORREIA, 2004: p.7).
\end{abstract}

O primeiro período da República é, portanto, caracterizado pela forte ambigüidade no tratamento do cortiço: de um lado, a legislação que reconhece a existência dos cortiços, define padrões mínimos de habitabilidade e estabelece

\footnotetext{
24 Para o "Cadastro de Habitações do Distrito Federal" de 1895, havia domicílios em todas as edificações da cidade, isto é, em prédios destinados a usos comerciais, industriais, etc. (VAZ, 1998: p.46)
} 
impostos ${ }^{25}$; de outro, as leis que proíbem sua existência, definem a vila operária como moradia própria ao operário e incentivam sua construção pela isenção de impostos ${ }^{26}$.

Essa forma de intervir se manteve até a década de 1930. Porém, a partir da publicação do Código de Posturas, de 1932, não se encontram menções à existência e à regulamentação, ou proibição de cortiços. Esse silêncio se mantém por 60 anos até a aprovação da Lei n. 10.928 da cidade de São Paulo, conhecida por Lei Moura, a redefinir e normatizar, em 1991, padrões mínimos para sua legalidade ${ }^{27}$.

${ }^{25}$ Código de Posturas de 1886, Padrão Municipal de 1889 e a Lei nำ286/1896.

${ }^{26}$ Lei no315/1897; Lei nำ493/1900; Lei nㄴ498/1900; Lei nำ1098/1908.

${ }^{27}$ Um objetivo importante dessa lei foi estabelecer parâmetros para que pudesse ser exigida e fiscalizada pela prefeitura a melhoria do imóvel pelo proprietário. As condições mínimas de habitabilidade exigidas são: área de iluminação da janela igual a $1 / 7$ da área do piso e a de ventilação igual à metade da área de iluminação; área mínima do cômodo de $5 \mathrm{~m}^{2}$ e pé-direito mínimo de 2,3m. Deve existir um tanque e um banheiro com vaso sanitário, pia e chuveiro para cada 20 moradores. 


\subsection{Ações e Programas Habitacionais voltados à Habitação de Interesse Social em Áreas Centrais Metropolitanas - experiências recentes}

Durante o século $X X$, se observam diferentes formas de tratamento da questão do cortiço na legislação urbanística e nas políticas públicas de intervenção. Elas revelam a complexidade da questão e as diferenças políticas ao enfrentá-la.

Em dois momentos, separados por mais de um século, a legislação urbanística reconhece a existência dessa forma de habitação e propõe normas para regulamentar padrões mínimos de habitabilidade. As normas e regulamentações do final do século XIX e início do XX tinham cunho sanitarista e disciplinador. Colocam-se medidas de caráter restritivo, proibindo a construção e permanência de cortiços, casas de cômodos e cubículos, em locais identificados por "perímetro do comércio". Ou seja, a principal forma de moradia da classe de renda mais baixa ficava proibida nas áreas centrais das principais cidades brasileiras.

Em São Paulo, a partir da década de 1930, diversos estudos e levantamentos são realizados, evidenciando reminiscências dos cortiços tão combatidos no período anterior, além de novos aspectos que se colocam ao longo do tempo. Tais pesquisas são importantes para o entendimento das questões que envolvem esta alternativa habitacional nos dias atuais. Mostram que essa é uma realidade difícil de captar, de forma precisa, por pesquisas de caráter quantitativo. Essa dificuldade se expressa principalmente, pela falta de um consenso quanto à definição do cortiço, e também por sua dinâmica interna, marcada por transformações constantes, alta rotatividade e clandestinidade, em meio a muitos interesses mercadológicos envolvidos.

As estimativas quanto ao porcentual da população moradora em cortiços, em geral, são bastante frágeis, desde sua conceituação até sua mensuração. Isso se deve mais às características do objeto que à qualidade das pesquisas. As condições de precariedade se transformam, mas é a relação entre vulnerabilidade social e precariedade urbana, características do cortiço, que explicam sua existência e permanência há mais de um século e tem representado um enorme desafio para uma atuação consistente do poder público.

Pesquisa realizada por Urbina Telles, entre 1937 e 1940, abrangeu um território amplo, evidenciando a crescente importância deste tipo de habitação. Os levantamentos domiciliares promovidos por pesquisadores sociais não visavam estimativas quantitativas em relação ao número de cortiços ou número de pessoas encortiçadas, apenas focava as condições de vida nos cortiços de bairros paulistanos. 
Os cortiços analisados eram conseqüência do progressivo deslocamento das classes de renda alta e média alta em direção a novas áreas com maior prestígio. Algumas dessas casas, então abandonadas, foram alugadas e progressivamente sublocadas.

Poucos anos depois, em 1947, sob os auspícios do Serviço Social da Indústria, Departamento de São Paulo, foi realizada uma pesquisa sob a direção do padre dominicano francês Lebret, professor contratado pela Escola de Sociologia e Política de São Paulo e fundador do movimento conhecido como Économie et Humanisme. Os resultados apresentaram indícios dos novos processos de estruturação urbana: o empobrecimento crescente das áreas centrais, a formação de bairros jardins exclusivos de classe de renda mais alta e a periferia ainda de caráter rural.

Em 1961, em trabalho considerado clássico sobre a habitação coletiva de aluguel em São Paulo, Lagenest notou que "o cortiço não representa uma unidade; é um ser híbrido, que se divide em três partes muito diferentes: os porões, as meiaságuas, muitas vezes construídas no quintal, e os andares superiores" (LAGENEST, 1962: p.7). Ele calculava que a população que "vivia em condições de habitação infrahumana", entre favelas e cortiços fosse por volta de 700 mil habitantes, dos quais $90 \%$ seriam moradores de cortiços concentrados em bairros centrais e representariam $18 \%$ da população municipal (PICCINI, 1991: p. 55).

O Plano Urbanístico Básico (PUB), uma pesquisa extensiva realizada pelo Consórcio Asplan - Daily - Montreal - Wilbur Smith, estudou o cortiço em São Paulo sob o ponto de vista qualitativo. Alguns resultados dessa pesquisa, publicados em 1968, apontavam que a principal característica observada nos cortiços era seu supercongestionamento. Geralmente constituídos por casas antigas em avançado estado de obsolescência, subdivididas em várias unidades domiciliares, quase sempre as instalações sanitárias e a cozinha eram de uso comum e as condições sanitárias eram extremamente precárias. Mostrava que existiam em São Paulo três tipos principais de unidades habitacionais em cortiços: subdivisões - improvisadas ou não de antigas mansões em decadência; porões subdivididos; e barracos de quintal ou meias-águas, os quais eram, geralmente, pequenos quartos de 3,0 metros por 3,0 metros com uma porta e uma pequena janela. Na maioria dos casos esses três tipos se combinavam em uma única unidade. Estavam concentrados, predominantemente, nas áreas que circundam o centro da cidade (MOREIRA, 2006: p. 12-20).

Mediante o levantamento global, verificou-se que nos 57 cortiços selecionados viviam 329 famílias e 1.101 pessoas. Considerando-se apenas os setores 
pertencentes ao município de São Paulo, observou-se que 10,3\% das famílias e 8,1\% da população viviam em cortiços. Dos cortiços localizados no município de São Paulo, $56,1 \%$, ou seja, mais da metade estava concentrada nas áreas centrais da cidade. Quanto aos tipos de unidades domiciliares de cortiço, a maior freqüência era de barracos de quintal $(48,3 \%)$, pouco mais do que a quantidade de cômodos situados em andares superiores (45,8\%). Os cômodos de porões representaram apenas 5,9\% do total. O grau de congestionamento era bastante alto. Os índices relativos ao número de famílias e de pessoas por cortiço era de 6,2 e 19,2 respectivamente nos setores Centro, Brás e Móoca, e de 5,3 e 19,5 nos demais setores (idem).

As condições sanitárias dos cortiços foram avaliadas mediante alguns índices derivados do número de aparelhos sanitários e de chuveiros, associados ao número de pessoas e de famílias. Os índices resultantes $-7,8$ pessoas por aparelho sanitário, 10,3 pessoas por chuveiro, 2,6 famílias por aparelho sanitário e 3,3 famílias por chuveiro - demonstravam o baixo nível sanitário dessas moradias. Quanto à condição de ocupação, verificou-se que $74,5 \%$ das famílias pagavam aluguel, $15,6 \%$ eram proprietários e 9,9\% tinham cômodos cedidos. Entre as famílias que viviam em cortiços, a mobilidade residencial era alta: $41,1 \%$ permaneciam, em média, menos de 1 a 4 anos em cada moradia; $40 \%$ de 4 a 10 anos, e 18,9\% mais de 10 anos. O tempo médio de permanência nos cortiços era também pequeno: $34 \%$ residiam há menos de 2 anos; $20 \%$ de 2 a 5 anos; 19,9\% de 3 a 10 anos; e 26,6\% de 10 a 30 anos. Verificouse que a proximidade com os locais de trabalho era um fator importante no processo de escolha do local residencial entre os chefes de família entrevistados durante a pesquisa: $44,6 \%$ declararam não necessitar de condução para ir ao trabalho - uma cifra expressiva. Quanto à percepção dos chefes de família em relação às condições habitacionais, verificou-se que a maioria (56,7\%) declarou não estar satisfeita. Quanto à origem dos chefes de família entrevistados, apenas 15,6\% nasceram nos municípios da Grande São Paulo; 35,6\% nasceram em outros municípios do estado; 42,2\% em outros estados; e 6,6 em outros países. Para o total da população, essas percentagens eram de 28,2\%, 35,8\%, 20,5\% e 15\%, respectivamente. Em termos relativos, há, portanto, mais migrantes de outros estados nos cortiços do que em toda a população pesquisada. Quanto ao grau de instrução, verificou-se que $20 \%$ eram analfabetos, 37,8\% eram semi-analfabetos (primário incompleto), 35,5\% cursaram o primário completo, 5,6\% o ginásio completo e 1,1\% o científico completo. Enquanto para toda a população o número de analfabetos e semi-alfabetizados correspondia a $24,3 \%$, nos cortiços essa cifra era de $57,8 \%$ (ibidem). 
Em 1975, a Secretaria do Bem-Estar Social, estudando o fenômeno a partir de informações de Rendas Imobiliárias, estimou em 9,3\% a população moradora de cortiços. O conceito de cortiço foi o de unidade habitacional coletiva de aluguel, ou seja:

\begin{abstract}
refere-se ao conjunto de edificações existentes no mesmo lote urbano, podendo assumir 3 formas: casarões, porões e meias-águas. Estas formas ocorrem em combinação ou isoladamente. Outra característica dessas edificações é a sua subdivisão em cômodos alugados (ou sublocados), embora raramente com contrato formal de locação (...). O cortiço define-se ainda pela coabitação involuntária, entendida como o uso de uma mesma habitação por mais de uma família. Além disso, caracteriza-se também pelo congestionamento, isto é, super lotação de pessoas no mesmo ambiente. Outro traço definidor do cortiço é o uso em comum das instalações sanitárias, em geral precárias (SÃO PAULO, 1975: s/p, apud MOREIRA, 2006: p.15 e 16).
\end{abstract}

O número médio de pessoas por cortiço foi de 26,9 e a área média construída por morador de 3,1 $\mathrm{m}^{2}$; os indicadores sanitários mostraram 8,7 pessoas por sanitário e 9,8 pessoas por tanque (TEIXEIRA, 1985).

Até a década de 1970, as pesquisas projetavam diferentes porcentagens da população encortiçada na cidade de São Paulo. Kowarick e Ant (1982) relatavam cerca de 500 mil pessoas moradoras de cortiços. Em 1980, novas estimativas da Secretaria Municipal de Planejamento (Sempla) apontavam que a população encortiçada representaria algo próximo de $17 \%$ da população municipal, isto é, quase 800 mil pessoas. Tabulações especiais do Censo Demográfico de 1980 desmentem esta cifra. Utilizando como indicador o porcentual de domicílios alugados com banheiro coletivo - o tipo mais característico de domicílio em cortiço, embora esteja longe de ser o único - concluiu que $10,03 \%$ do parque domiciliar paulistano era composto por aproximadamente 182 mil unidades encortiçadas. Outro dado importante dessa tabulação foi a constatação que o porcentual de domicílios alugados, com cômodo único (certamente cortiços), sobre o total de domicílios alugados era de 5,6\% em 1970, e sobe para 8,5\% em 1980 (PASTERNAK, 1990).

A partir da década de 1980, observam-se algumas tentativas - ainda que pontuais - de programas de intervenção em cortiços e políticas de produção de habitação social em áreas centrais. Em geral, acontecem no município de São Paulo, principalmente pelas proporções tomadas pela questão - evidenciadas pelas inúmeras invasões de prédios abandonados no centro da cidade -, e o grande movimento de 
discussão sobre a questão do direito à moradia por estudiosos e através dos movimentos de luta por moradia. Por isso mesmo, destacamos algumas ações observadas nos últimos 25 anos, como forma de analisar os limites e entraves estabelecidos para que de fato ocorra uma política abrangente de promoção pública de habitação de interesse social em áreas centrais.

A década de 1980 é marcada pela retomada do reconhecimento da existência de cortiços na área central de São Paulo, por parte do poder público. Em 1984, durante a gestão de Mário Covas, é constituído o Plano Habitacional do Município de São Paulo - 1983/87, composto por políticas - que se voltavam para a questão da terra, dos recursos (reestruturação do Funaps - Fundo de Atendimento à População Moradora em Habitação Subnormal, para financiamentos e subsídios), da participação da iniciativa privada (Operações urbanas como forma de obtenção de terras para produção de Habitação de Interesse Social - HIS) e da participação da comunidade; por programas - lotes urbanizados, lotes urbanizados com embrião, oferta de unidades habitacionais acabadas, urbanização de favelas, melhoria em cortiços existentes, melhora em loteamentos precários, oferta de habitação de aluguel; e por ações complementares - apoio técnico-administrativo à autoconstrução e mutirão, suprimento de materiais de construção, revisão da legislação sobre habitação popular, constituição de um sistema de informações habitacionais. A moradia é tida como um direito e o conceito adotado foi o da habitação "vista não apenas como um abrigo e sim como uma unidade física e familiar inserida no meio urbano, com seus complementos de paisagem, infra-estrutura, transporte, abastecimento e equipamentos sociais" (apud DIOGO, 2004: p.174).

O Programa de Melhoria em Cortiços teve como objetivo a reforma dos imóveis encortiçados e a definição de critérios para regularização e fiscalização. A estimativa do programa era de atendimento a 7.000 famílias até 1987, o que representava 390 imóveis e 20.860 moradores. A linha de ação envolvia: escolha de área para intervenção considerando a concentração de cortiços; "estímulo a formas coletivas para autogestão do uso e manutenção do cortiço, relação com o proprietário e negociação dos aluguéis, tendo em vista eliminar intermediários"; indicação de soluções construtivas específicas; individualização da cobrança de contas de água e luz e intermediação da negociação entre moradores e proprietários (idem).

O programa de oferta de habitação de aluguel previa a provisão, em caráter experimental, da habitação desvinculada do compromisso de compra visando atender 
famílias com renda entre 2 a 5 salários mínimos. Assim como o programa de cortiços, esse também seria implementado em escala reduzida devido à falta de experiência anterior. Seriam geridos pela Secretaria de Habitação (SEHAB), por meio da Emurb e da Cohab.

Em 1985, foi apresentada a proposta do Plano Diretor do Município de São Paulo $1985-2000^{28}$, elaborado por uma equipe de mais de 100 técnicos da Secretaria de Planejamento dirigida por Jorge Wilheim, dentre eles alguns professores e pesquisadores como: Flávio Villaça, Sarah Feldman, Nádia Someck e Paul Singer. Foi elaborado no contexto de redemocratização, antes da aprovação da constituição de 1988.

Uma das expectativas do plano era de mudanças nos demais níveis governamentais, "especialmente mediante a adoção de instrumentos legais novos [...] que autorizem o Município a intervir democraticamente no meio urbano, no interesse da coletividade" (SEMPLA, 1985: p.17). Anuncia-se inovador no processo de planejamento participativo, entendendo que "participar significa influir, mas não, necessariamente, decidir, sendo uma prática que exercita e aperfeiçoa a democracia, aumentando a confiança dos grupos sociais em si próprios"(SEMPLA, 1985: p.21).

Para a área central, destaca-se que "a análise do grau de aproveitamento de seus terrenos e a identificação de áreas deterioradas em suas vizinhanças constituem provas da estagnação que vem ocorrendo há anos, especialmente a partir de 70" (SEMPLA, 1985: p.28). A estagnação aparece como decorrência do deslocamento das atividades comerciais para a Av. Paulista, "restando com isso no Centro Principal, áreas onde o excelente potencial locacional e a infra-estrutura disponível encontramse subutilizadas e deterioradas. Nessas áreas, as edificações mais antigas vêm sendo gradativamente encortiçadas"(SEMPLA, 1985: p.28).

Com relação ao Centro Principal, o plano recomendava que:

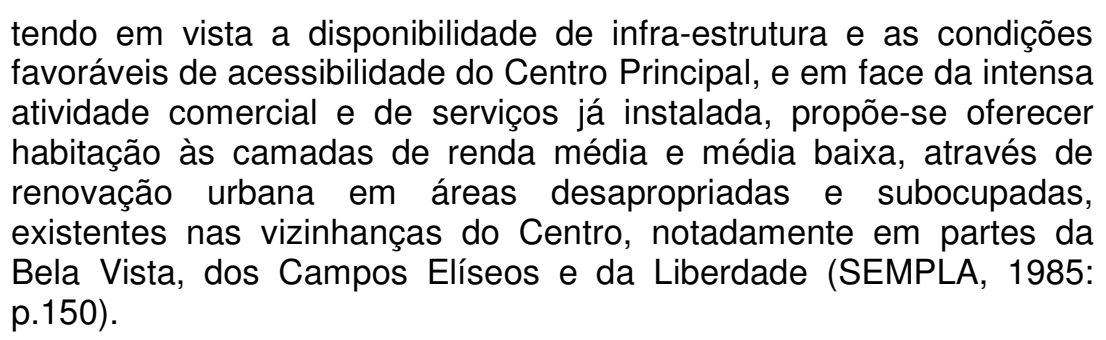

${ }^{28}$ SÃO PAULO (Município) - Sempla. Plano Diretor do Município de São Paulo 1985-2000. São Paulo, 1985. 
Tais projetos específicos tinham como principal instrumento as operações urbanas, sendo, portanto, propostas 35 operações urbanas, dentre elas a do Centro. Ficou evidente, no entanto, que as operações urbanas com interesse voltado para a habitação popular continuavam concentradas nos bairros periféricos e não na área central.

O livro Cortiços: Frente e verso ${ }^{29}$, publicado pela Secretaria Municipal de Planejamento (SEMPLA), em 1985, na gestão de Jânio Quadros, descrevia as condições dos cortiços e dos encortiçados. A estimativa numérica apresentada, de 2.700.000 moradores em cortiço, é hoje considerada bastante superestimada. Como hipótese de trabalho, apresentara que a taxa de crescimento da população encortiçada crescia a taxas iguais à população favelada, pelas mesmas condições de empobrecimento. O texto argumenta que:

\begin{abstract}
se em 1975 a população favelada representava $2,2 \%$ da população do município e a encortiçada 9,3\%, e em 1980 as favelas abrigavam $4,2 \%$, guardando-se as mesmas proporções de crescimento, os cortiços estariam representando $17,7 \%$ da população total. Assim, para 1980, a população encortiçada se aproximaria de 1,7 milhões de pessoas, devendo estar atualmente (1985) por volta de 2,75 milhões de pessoas (SÃO PAULO, 1985: p.14).
\end{abstract}

Essas estimativas partem de pressupostos, no mínimo, discutíveis. Cortiços e favelas são fenômenos com distintas dinâmicas. Se a grande causa é comum: falta de unidades habitacionais a preços condizentes com a renda dos usuários, todas as outras variáveis se comportam de forma diferente. Não há razão para a suposição do mesmo padrão de crescimento.

A tipologia utilizada nessa pesquisa (1986), e depois retomada pela FIPE (1994), classifica os cortiços em dois tipos: imóveis construídos para outro uso e adaptados para cortiços pela subdivisão da edificação, e imóveis concebidos para serem cortiços, cubículos em torno de um pátio. Os aspectos considerados no conceito de cortiço são:

habitação coletiva com índice de ocupação excessivo; deficiências de instalações hidráulicas e sanitárias; cômodos alugados e congestionados com uso comum do banheiro e, eventualmente de cozinhas; várias funções exercidas no mesmo cômodo; cohabitação involuntária e pouca ou nenhuma privacidade (SEMPLA, 1985: p.13).

${ }^{29}$ SÃO PAULO (Município) - Sempla. Cortiços em São Paulo, frente e verso. São Paulo: Sempla, 1985. 
Além desses, consta o fato do cortiço ser uma fonte de geração de renda, argumentando-se que os proprietários e/ou soblocadores exploram os moradores com aluguéis incompatíveis com a qualidade das moradias. A pesquisa foi realizada em 65 cortiços do município, sendo 30 no anel central, 27 no intermediário e 8 no periférico. Classificou-se ainda a tipologia dos mesmos, sendo 46,2\% imóveis adaptados para cortiços e $53,8 \%$ imóveis concebidos como cortiços. No anel central, os imóveis adaptados corresponderam a $76,7 \%$ e os concebidos a $23,3 \%$, sendo os projetados para este fim anteriores a 1930. Os imóveis encortiçados do Anel Central corresponderam a $46,2 \%$ do total de cortiços do município.

Existia naquele momento uma forte indicação da necessidade de intervir nos cortiços, sobretudo por ter a atuação da Secretaria do Bem Estar Social (SEBES) até então se restringido a experiências piloto.

Durante a gestão de Luiza Erundina, a SEHAB se propôs a enfrentar 0 problema dos cortiços como uma nova forma de moradia na Área Central e não mais como uma questão de assistência social como aconteceu em gestões anteriores. A influência e cooperação francesa ${ }^{30}$ é fato importante à medida que aponta "que, para que a comunidade e a iniciativa privada assumam suas tarefas no esforço de reabilitação do centro (esta é uma tarefa de todos, sem dúvida), cabe ao poder público dar os primeiros passos" (DIOGO, 2006: p.189).

O arquiteto Nabil Bonduki, então Superintendente de Habitação Popular, considerava o enorme crescimento dos cortiços e a necessidade de romper com a expansão dos assentamentos periféricos. Foram desenvolvidas duas experiênciaspiloto: uma para o Casarão Celso Garcia e outra para o conjunto Madre de Deus; e ainda um Concurso Público de Anteprojetos para Habitação Popular no Brás.

As propostas habitacionais foram consolidadas no documento "Cortiços. Programa de Habitações Populares da Região Central de São Paulo"31, que detectou o aumento dos cortiços na década de 1980, como decorrência de um novo padrão de crescimento da cidade. A análise, baseada nos dados da Sempla ${ }^{32}$, indicou que a periferia cresceu menos que nas décadas anteriores e que houve um aumento da população de baixa renda em determinados distritos do anel central. Estimou-se que a população encortiçada era da ordem de $28 \%$, ou seja, 3 milhões de pessoas,

\footnotetext{
${ }^{30}$ Na gestão da prefeita Luiza Erundina foi assinado um Convênio de Cooperação Técnica com a França para analisar a experiência francesa de reabilitação de velhos centros urbanos.

${ }^{31}$ SÃO PAULO (Município) - Sehab. Cortiços. Programa de Habitações Populares na Região Central de São Paulo. São Paulo: Sehab, 1992.

${ }^{32}$ SÃO PAULO (Município) - Sempla. São Paulo. Crise e Mudança. São Paulo: Brasiliense, 1991.
} 
enquanto que na década anterior era de 19\%, ou seja, 1,7 milhão de pessoas. A definição de cortiço adotada no documento foi:

habitação coletiva precária de aluguel, constituída por cômodos alugados em uma ou mais edificações no mesmo lote urbano, onde coabitam famílias e indivíduos sós ou associados, com utilização comum, no todo ou em partes, de áreas de acesso e de equipamentos sanitários e de serviços (Sehab, 1992).

As propostas de intervenção em cortiços estavam respaldadas pelo Plano Diretor do Município de São Paulo ${ }^{33}$, que propunha a delimitação de Zonas Especiais de Interesse Social (ZEIS $4^{34}$ ) para as áreas de cortiços. Além do Plano Diretor, a lei proposta pelo vereador Luís Carlos Moura (lei 10.928 de 08 de janeiro de 1991), conhecida até hoje como Lei Moura, definiu tanto o objeto como as condições mínimas de habitabilidade para os cortiços. Segundo essa definição:

Art. 1ํ - Define-se como cortiço a unidade usada como habitação coletiva, apresentando total ou parcialmente, as seguintes características:

a) constituídas por uma ou mais edificações construídas em lote urbano;

b) subdividida em vários cômodos alugados, subalugados ou cedidos a qualquer título;

c) com superlotação de pessoas no mesmo ambiente;

d) uso comum dos espaços não edificados, sanitários, etc.;

e) circulação e infra-estrutura em geral precárias.

As duas linhas de atuação do programa de cortiços foram: Programa de produção de Habitação de Interesse Social (HIS); e Programa de recuperação de cortiços.

O Programa de Produção de HIS previa a produção de novas unidades habitacionais, equipamentos para o bairro e regularização dos imóveis encortiçados. Os bairros centrais e o Anel Intermediário eram considerados prioritários e as áreas de intervenção deveriam ter como características: infra-estrutura com capacidade de adensamento; subutilização ou existência de vazios; presença de imóveis deteriorados; interesse urbanístico; concentração de população de baixa renda; e possibilidade dos proprietários participarem dos empreendimentos. $O$ atendimento da Funaps seria para famílias com renda entre 1 e 4 salários mínimo, e, além desses

\footnotetext{
${ }^{33}$ SÃO PAULO (Município) - Sempla. Plano Diretor do Município de São Paulo. São Paulo, 1992.

${ }^{34}$ Definidas como áreas com concentração de habitação coletiva precária de aluguel onde haja interesse público de se promover programas habitacionais destinados prioritariamente à população de baixa renda moradora da região.
} 
recursos, estava prevista a criação de um Fundo de Urbanização com recursos provenientes da outorga onerosa.

O Programa de Recuperação de Cortiços propôs instrumentos de gestão conjunta entre poder público, movimentos populares e suas assessorias técnicas. $O$ programa estabeleceu dois subprogramas que poderiam ser combinados: 1) Financiamento para aquisição de imóveis encortiçados por famílias associadas, tendo como pressuposto a propriedade coletiva do aluguel; 2) Financiamento para a reforma de imóvel encortiçado.

Dois aspectos bastante valorizados pelo programa foram a participação da comunidade com a autogestão dos empreendimentos financiados pela Prefeitura Municipal de São Paulo e a fixação da população na região, em contraponto à tendência histórica de expulsão da população de baixa renda para regiões periféricas.

Diante da escassez de recursos e de tempo para execução das ações durante a gestão municipal em curso, a Sehab definiu como metas para consolidação do programa a implementação de algumas experiências em edificações e a elaboração da legislação. Consta do documento um alerta para a necessidade de participação dos movimentos populares para garantir a continuidade do programa.

O Programa de Recuperação de Cortiços teve início com a assinatura de três convênios com as seguintes associações de construção comunitária da Região do Ipiranga: Imoroty (20 famílias), Pedro Fachini (20 famílias) e Eiras Garcia (24 famílias).

Foi elaborado um relatório final que apresentou todas as ações planejadas, concluídas e em execução até novembro de 1992 pela Superintendência de Habitação Popular $^{35}$. Ainda no último ano de gestão foi publicado um encarte especial da revista Projeto intitulado "Habitação e Urbanismo. Da utopia à construção. A participação popular na política habitacional em São Paulo", que apontava como premissa para a política habitacional, sua vinculação à política urbana. $\mathrm{O}$ direito à terra, o direito à arquitetura, o direito à cidadania, a participação da população nas formulações e implantações de programas e projetos, a diversidade de intervenções, o reconhecimento da cidade real, a redução de custos sem perda da qualidade, 0 estímulo à autogestão e o respeito ao meio ambiente deveriam ser pressuposto às ações previstas. A matéria incluía o projeto do Casarão da Avenida Celso Garcia.

\footnotetext{
35 SÃO PAULO (Município) - Sehab. Programa Habitacional de Interesse Social - Relatório de Gestão 1989 - 1992. Administrações Lapa, Sé e Pinheiros. São Paulo: Sehab, 1992.
} 
Um último documento intitulado "Recuperando Sampa. Reabilitação do Centro de São Paulo" explicitava uma intenção clara de intervir no Centro, resgatando-o para os pobres: "Reabilitar o Centro sem expulsar seus moradores pobres é um desafio que poucas cidade do mundo conseguiram vencer".

Na gestão seguinte, do prefeito Paulo Maluf, a linha de atuação municipal foi alterada. O Programa de Requalificação Urbana e Funcional do Centro de São Paulo (Procentro), criado em 1993, considerava, entre outros fatores, a importância simbólica da região e "a necessidade e a conveniência da implementação de ações que assegurem melhores condições ambientais à população e previnam deterioração e a desvalorização imobiliária da área”.

O Procentro foi concebido para ter atuação direcionada à solução de problemas qualificados como de deterioração ambiental e paisagística, de acesso, circulação e falta de estacionamentos, de obsolescência, subutilização e falta de investimentos no estoque imobiliário e de deficiência na segurança pessoal e patrimonial, em 15 áreas pré-estabelecidas, denominadas Pólos de Recuperação Urbana. A maioria das ações era de cunho estético, como recuperação de fachadas, regulamentação para anúncios, implantação de equipamentos e mobiliários urbanos, etc., incorporando a iniciativa privada através de incentivos fiscais. Ainda propunha o desenvolvimento de um plano de incentivo à cultura, lazer e turismo na Área Central.

A FIPE, utilizando a definição operacional de cortiço da Lei n504/89 - a chamada Lei Moura -, em 1994, realizou uma pesquisa tentando atualizar os dados sobre cortiços e reduzir a incerteza nas estimativas. Sua pesquisa foi do tipo amostral, por sorteio, com base na densidade de cortiços indicada pelo Cadastro de Rendas Imobiliárias da Secretaria de Finanças do Município.

Finalizado o trabalho, obteve-se uma estimativa de 23.688 imóveis encortiçados em São Paulo, compreendendo 160.841 famílias e uma população de 595.100 pessoas, que correspondem a cerca de $6 \%$ da população paulistana. Esse resultado, perante as outras estimativas anteriores, foi surpreendente: "apenas" 600 mil pessoas moradoras de cortiços, cerca de $6 \%$ da população do município, concentrados na então Administração Regional da Sé, na qual 20,4\% das famílias moradoras são encortiçadas; além da região da Mooca, com 16,2\%, e de Vila Prudente, com $7,01 \%$. Os dados indicam que $46 \%$ dos imóveis foram construídos com a finalidade de serem cortiços. Os indicadores mostram a exigüidade de espaço e conforto: a superfície média dos domicílios é de $11,9 \mathrm{~m}^{2}$, com $4,1 \mathrm{~m}^{2}$ por pessoa e 7,04 
domicílios por imóvel; o número de pessoas por domicílio é 2,90, com 2,45 por cômodo, 6,32 por chuveiro, 9,25 por pia, e 5,91 por sanitário. A pesquisa ainda indicou, considerando-se todos os moradores dos imóveis encortiçados, que $42,8 \%$ se encontravam trabalhando. Dos demais, 33\% estavam na faixa inferior a 14 anos, 7,8\% desempregados, 2,3\% aposentados e 12,9\% nunca trabalharam. A renda mensal dos trabalhadores era, como já se esperava, bastante baixa: a grande maioria - 51,8\% recebia entre 1 a 3 salários mínimos. Apenas 14,2\% dos trabalhadores recebiam mais de 5 salários mínimos. O valor do aluguel pago pelos moradores de $54 \%$ dos domicílios, no mês anterior à pesquisa, ou seja, em fins de 1993, estava na faixa de até 0,5 salário mínimo; para $26 \%$ dos domicílios, o aluguel se situava entre 0,5 e 1 salário mínimo. O consumo de luz e água, para a maioria das famílias, em 1993, era menor que o correspondente a 0,25 salários mínimos (FIPE, 1994).

Em 1997, já na gestão de Celso Pitta, foi divulgado o Projeto HabiCentro que "[...] tem como objetivo dar continuidade às propostas de 'Revitalização sustentada' do centro urbano da Capital, discutidas no Procentro, podendo ser citadas como exemplos as propostas apresentadas no 'Concurso de Idéias ${ }^{36}$, promovido pela 'Viva o Centro'”.

Após uma análise urbanística bastante superficial da Área Central, o Projeto HabiCentro indicava possíveis alternativas para tratar "o problema da habitação no centro", entre elas: Projetos habitacionais para classe média; Operação cortiço; Projeto terceira idade; e Projeto Residencial Estudantil.

Foi proposta a reforma de um imóvel para uso de HIS na Rua Baronesa de Porto Carreiro, na Barra Funda, que apresentava na descrição de localização a observação: "área de grande visibilidade".

Em dezembro de 1997, o Procentro apresentou o documento "Propostas para Habitação na Área Central", que colocava a existência de cortiço como um indício do potencial habitacional da região e indicou duas frentes de atuação: Habitações para a classe média na zona cerealista e no pátio do Pari; e Recuperação de áreas degradadas e encortiçadas com construção de novas edificações em terrenos subutilizados e reforma de edificações vazias.

${ }^{36}$ O Concurso Nacional de idéias para um novo Centro de São Paulo foi promovido pela Comissão Procentro da Sehab, organizado pelo Instituto dos Arquitetos do Brasil - IAB, com o apoio da Associação Viva o Centro, Fundação Banco de Boston e Rede Ferroviária Federal. 
A Unificação das Lutas de Cortiços (ULC) e o Fórum dos Cortiços conseguiram que o Procentro definisse um projeto piloto com 42 imóveis no Centro, sendo: 24 construções novas, 10 reformas e 8 reciclagens. O valor da intervenção seria de $\mathrm{R} \$ 56,5$ milhões, o que representaria um custo unitário no total de $R \$ 19.780,00$. $O$ projeto piloto limitou o preço de comercialização a $R \$ 15.000,00$, valor considerado condizente com a capacidade das famílias, e a diferença entraria como subsídio. A recuperação de áreas degradadas e encortiçadas foi objeto de pedido de financiamento para o Banco Interamericano de Desenvolvimento (BID). Ainda em relação aos cortiços, fez parte da proposta a transferência da população moradora para conjuntos habitacionais e a criação de um programa de locação social para as habitações encortiçadas.

Em junho de 1997 foi instituída a Operação Urbana Centro (OUC) que estabeleceu um programa de melhorias para a Área Central, criando incentivos e propondo formas para sua implantação, cujo perímetro de atuação era o mesmo do Procentro. As ações voltavam-se para a cultura e o lazer.

Em 1997, a FIPE realiza outro estudo e, a partir dos dados obtidos, considera que o processo de encortiçamento na área central é pouco dinâmico. O relatório final "Diagnóstico e plano de ações para o mercado de moradia de aluguel e identificação de obstáculos para aquisição de novas moradias pelas famílias de baixa renda", contratado pela Sehab, apresenta as conclusões da pesquisa socioeconômica sobre as condições dos moradores da Área Central, alternativas de intervenção, um levantamento sobre os programas para cortiços elaborados nas administrações municipais e estaduais desde a década de 1980, uma análise do mercado imobiliário de moradias populares e um levantamento dos estudos sobre moradias para população de baixa renda em São Paulo. O conceito de cortiço adotado é o mesmo da Lei Moura ${ }^{37}$, incluindo alguns itens e excluindo as casas coletivas.

Os resultados confirmaram os dados do estudo realizado pela própria FIPE, em 1994, que indicava a existência de quase 600.000 moradores em cortiços. Os dados de 1997 indicam um total de 8.196 cortiços contra 10.361 em 1994, sendo que uma variação de $20 \%$ seria desprezível do ponto de vista estatístico.

\footnotetext{
37 De acordo com a Lei Moura, cortiço é a unidade usada como moradia coletiva multifamiliar, apresentando, total ou parcialmente, as seguintes características: constituída por uma ou mais edificações em lote urbano; subdividida em vários cômodos alugados, subalugados ou cedidos a qualquer título; várias funções exercidas no mesmo cômodo; acesso e uso comum dos espaços não edificados e instalações sanitárias; circulação e infra-estrutura, no geral precárias, e superlotação de pessoas.
} 
A política para a Área Central de São Paulo na gestão da prefeita Marta Suplicy pode ser entendida a partir de três frentes. No primeiro momento, a gestão apresentou o Plano Reconstruir o Centro, elaborado pelo Procentro (que havia sido reformulado) sob a coordenação da Administração Regional da Sé, tendo a pesquisadora Sarah Feldman como consultora. O plano definia as diretrizes do governo para a Área Central e indicava, preliminarmente, o papel da habitação nesse contexto por meio do Programa Morar no Centro. O plano em si, não passou desta etapa inicial, mas o Morar no Centro se desenvolveu dentro da estrutura da Sehab.

A segunda frente se constituiu a partir do Plano de Reabilitação da Área Central (também conhecido como Ação Centro), desenvolvida pela Emurb, em 2003, e atrelado a um contrato de financiamento com o BID, firmado na gestão anterior, porém adaptado à nova realidade política. Tinha como objetivo promover o "desenvolvimento social e econômico, com diversidade, da Área Central de São Paulo, dinamizando e criando condições de atração e suporte de atividades compatíveis com o Centro Metropolitano e promovendo a reabilitação urbanística e ambiental da área". O Morar no Centro acabou sendo incorporado à Ação Centro, já que este previa ações mais gerais de reversão da desvalorização imobiliária e recuperação da função residencial. A Ação Centro foi objeto de financiamento, herdado da gestão anterior, firmado entre a PMSP e o BID.

A terceira frente, constituída pelo Plano Diretor Estratégico (PDE) e pelo Plano de Habitação, apesar de não se relacionar exclusivamente com a Área Central, é fundamental para a compreensão do contexto global. Diversos programas habitacionais, modalidades de atendimento, recursos, formas de gestão e instrumentos urbanísticos compõem o quadro habitacional do período.

O Plano Reconstruir o Centro tinha como objetivos: "o resgate do caráter público dos espaços públicos, a ampliação do uso residencial, a consolidação do caráter metropolitano da área central, uma atuação urbanística não excludente, uma gestão urbana voltada para interesses coletivos e a redução da violência". Para concretizá-los foram propostos oito programas: Andar no Centro, Cuidar do Centro, Descobrir o Centro, Governar o Centro, Investir no Centro, Morar no Centro, Preservar o Centro e Trabalhar no Centro.

O Plano apontou a região como subutilizada, com quase 40 mil domicílios vagos. Destacou, também, o legado de décadas de descaso das diversas instâncias 
do poder público em relação ao Centro, principalmente no tocante à manutenção e conservação da infra-estrutura e dos equipamentos urbanos.

Em 2002, a Sehab divulgou o documento "Habitação no centro: o Programa da Prefeitura", cuja proposta se dava no sentido de criar uma política habitacional abrangente e sustentável, que atendesse diferentes estratos da população e que fugisse do universo das intervenções pontuais. A necessidade de produzir habitação para as camadas de renda média baixa foi justificada pela combinação da existência de bairros ainda não disputados pelo mercado imobiliário, de terrenos vazios e edifícios passíveis de reforma, de edifícios de valor arquitetônico ou histórico passíveis de reabilitação para o uso habitacional, da capacidade da infra-estrutura instalada no Centro, considerada suficiente para receber um número muito maior de moradores, da oferta de empregos e da possibilidade de redução do número de deslocamentos. Atuaria, ainda, como uma alternativa para conter a expansão da população em direção às áreas frágeis e sem infra-estrutura.

O Programa Morar no Centro, por sua vez, objetivava contribuir para o repovoamento da área central, viabilizar moradia para população de baixa renda, reabilitar edifícios desocupados para uso habitacional e melhorar a qualidade de vida dos moradores da Área Central. As ações propostas foram: a implantação do Programa de Arrendamento Residencial (PAR), através de um convênio firmado entre a PMSP e a CEF, em maio de 2001; o Programa de Locação Social, para atendimento de famílias com renda mais baixa, sendo a gestão dos condomínios considerada o ponto frágil do programa; e os Perímetros de Reabilitação Integrada do Habitat (PRIH), com intervenções em conjunto de quadras com concentração de moradias precárias. Previa a combinação de ações de produção de unidades habitacionais (PAR, Programa de Locação Social, Carta de Crédito Individuais e Associativas), melhorias em cortiços, reabilitação do patrimônio, produção e melhoria de equipamentos públicos e de áreas verdes, ações culturais, de saúde, de educação, de capacitação profissional, de geração de emprego e renda, e criação de espaços destinados a atividades econômicas. A indicação dos perímetros foi realizada com base em estudos desenvolvidos por assessorias técnicas com o apoio dos movimentos de moradias. Esses perímetros, por sua vez, serviram de base para a definição das ZEIS do Plano Diretor Estratégico, aprovado em setembro de 2002; intervenções em terrenos ou prédios isolados produzindo novas unidades habitacionais a partir da reforma ou reciclagem de uso de edifícios vazios do Centro; continuidade de projetos iniciados em 1989 e 1992 (gestão Luiza Erundina); provimento de moradias transitórias, cuja 
demanda seria atendida por assessorias técnicas para a formação de cooperativas para produção residencial; incentivos para atrair famílias de classe média para a área central.

Os recursos previstos para a implementação do Morar no Centro vieram da Caixa Econômica Federal (PAR - Programa de Arrendamento Residencial e Cartas de Crédito), do Governo do Estado (por meio do Programa de Atuação em Cortiços PAC), do Fundo Municipal de Habitação (que substituiu o Funaps; orçamento municipal) e do BID (PAC e financiamentos à prefeitura). Além desses recursos, a prefeitura assinou acordos e convênios de cooperação técnica com o governo da França nas áreas de política urbana, habitacional e fundiária, formas de acesso à habitação e tecnologia de reabilitação de imóveis, e com a cidade de Turim para a capacitação técnica dos técnicos da Prefeitura.

Abrangia 13 distritos, distribuídos em 3 subprefeituras: Subprefeitura Sé e área de atuação da Ação Centro (Sé, República, Bom Retiro, Santa Cecília, Consolação, Bela Vista, Cambuci e Liberdade); Subprefeitura Mooca: Pari, Brás, Belém e Mooca; Subprefeitura Lapa: Lapa e Barra Funda..

A participação popular no Morar no Centro se deu por meio do Fórum dos Movimentos e Entidades do Centro. É reconhecida a importância dos movimentos de moradia na formulação de várias propostas desenvolvidas no âmbito do programa.

Em abril de 2004, foi lançada a publicação oficial do Programa Morar no Centro que consolida, organiza e divulga toda a proposta desenvolvida ao longo da gestão. A proposta apresenta-se estruturada em três formas de intervenção urbana: Projetos habitacionais em terrenos ou edifícios vazios; Perímetros de Reabilitação Integrada do Habitat (PRIH), que consiste em conjuntos de quadras que concentram moradias precárias e oportunidades para empreendimentos imobiliários, de reforma ou construção nova. A atuação nesses perímetros se contrapõe às intervenções isoladas e seus principais objetivos são a melhoria das condições habitacionais da área, a promoção da inclusão social da população de baixa renda, a mobilização e organização dos grupos sociais e a valorização das características e potencialidades do bairro e da comunidade; e Projetos Especiais, onde de imediato foram destacadas a requalificação da Foz do Tamanduateí/ Parque do Gato e a reabilitação do Edifício São Vito.

Para cada forma de intervenção poderiam ser adotadas algumas modalidades de atendimento habitacional de forma isolada ou combinada. Uma primeira 
modalidade era o Programa de Locação Social, que parte da elaboração de um parque público de locação na área central formado por unidades habitacionais novas ou requalificadas, para atendimento de famílias com até 3 salários mínimo ou renda per capita inferior a 1 salário mínimo, o que correspondia a parte significativa dos moradores de cortiços, definidos como demanda para o programa (FIPE, 1994). Dentro desta demanda tinha-se como prioridade a população atendida pelo Programa de Reabilitação e Atenção à Moradores de Vãos e Baixo de Viadutos e Pontes, moradores de cortiços com ações coletivas de despejo e condições críticas de habitabilidade, moradores de albergues, moradores da Favela do Gato, além de idosos e portadores de necessidades especiais. Os recursos seriam provenientes do Fundo Municipal de Habitação (parte em forma de subsídio e parte retornaria por meio do pagamento do aluguel mensal, que poderia comprometer, no máximo, de 10 a $15 \%$ da renda familiar) e do BID.

O sistema de gestão previa três instâncias de atuação: a do programa propriamente dito (Unidade de Gestão do Morar no Centro, que respondia pelo planejamento e controle operacional do programa, formação de parque público, acompanhamento jurídico, administrativo e financeiro dos recursos, monitoramento e avaliação do programa), a do parque público de locação (dividida entre técnica, financeira e sócio-educativa) e a dos condomínios (autogestão, terceirização para empresa especializada, ONG ou cooperativa).

Outra modalidade era o Programa de Arrendamento Residencial (PAR), do governo federal, criado pela Lei Federal n. 10.188/01, que consiste no arrendamento de construções novas ou reformadas, para famílias com renda de 3 a 6 salários mínimo, por um período de 15 anos. Ao fim do período, a família teria a opção de comprar o imóvel. O programa tinha como prioridade projetos em áreas de revitalização urbana e de recuperação de sítios históricos, de recuperação de áreas de risco e de preservação ambiental e de acesso a pólos geradores de emprego e renda. Entre os projetos estava o de reabilitação do Edifício São Vito e o Hotel São Paulo. O programa, entretanto, não apresenta política de subsídio, tornando-se inacessível para boa parte da população de baixa renda (atende, em geral, famílias com renda média de 5 a 10 salários mínimos).

Uma terceira modalidade corresponde ao Programa Bolsa Aluguel, que se trata de um subsídio temporário que complementa o valor do aluguel de um imóvel no 
mercado privado. A concessão varia de acordo com a renda e a composição familiar. O público prioritário eram os moradores de cortiços das áreas dos PRIHs.

A Moradia Transitória, outra modalidade, visava o atendimento de famílias em situação de risco ou casos de emergência. Consistia em subsídio para a locação de unidades habitacionais ou vagas em hotéis do mercado privado por um período de, no máximo, 2 anos. As famílias receberiam assistência social, tendo em vista a preparação das mesmas para a inserção no Programa de Locação Social ou outro.

Por fim, contava-se ainda com o Programa de Intervenção em Cortiços ou Melhoria das Condições de Vida em Moradias Coletivas Multifamiliares - Cortiços, que possibilitava a continuidade a cinco projetos de intervenção em cortiços iniciados na gestão 1989/92, totalizando 93 unidades habitacionais. Além das obras, foram desenvolvidas ações fiscalizatórias, com base na Lei Moura, de capacitação de moradores de cortiços sobre seus direitos e um mapeamento dos cortiços.

Em dezembro de 2003, foi assinado um convênio entre a PMSP e o governo estadual, para integrar as ações ao Programa de Atuação em Cortiços (PAC) ${ }^{38}$, que atua através da CDHU. O programa tem como propósito:

\begin{abstract}
recuperar e revitalizar as funções urbanas das áreas centrais degradadas, valorizando o potencial da infra-estrutura instalada para os usos de comércio e serviços especializados e, ao mesmo tempo, mantendo o habitat de parcela da população trabalhadora que vem sendo expulsa progressivamente para as periferias distantes em áreas de risco e proteção ambienta" (SÃO PAULO, 2002: p.4).
\end{abstract}

A concessão onerosa de uso por cinco anos, o subsídio direto ao imóvel e as cartas de crédito são as inovações do programa, atingindo desta maneira, famílias com renda média de 3 a 10 salários mínimos. Em sua primeira fase, o PAC atua em São Paulo e Santos. Definiu para ambos os municípios setores básicos de intervenção (SBIs), em função das concentrações de imóveis encortiçados, como forma de programar as atividades de planejamento, projeto, organização da demanda e gestão.

Em parceria com a Fundação Seade, elaborou, primeiramente, um detalhado levantamento cadastral dos imóveis encortiçados no perímetro dos setores identificados, além de uma pesquisa socioeconômica com os moradores, seguindo o que foi considerado altos padrões técnicos de pesquisa urbana e social. Os objetivos

${ }^{38}$ O Programa de Atuação em Cortiços - PAC, foi instituído em 1998 por decreto estadual e efetivamente implantado em junho de 2002, com a assinatura do Contrato de Empréstimo com o Banco Interamericano de Desenvolvimento - BID, no valor de 70 milhões de dólares. 
da pesquisa PAC - uma das mais recentes e completas sobre os cortiços do centro expandido - relacionavam-se com a proposta do programa, a qual se liga à possibilidade de verificar a potencialidade tanto de reciclar esses imóveis como da área alvo receber novas edificações para abrigar a população moradora em cortiços. $A$ pesquisa PAC, nos aspectos do levantamento cadastral da moradia levantava informações sobre condições externas do imóvel, seu estado de conservação, existência de porão, de cozinha, banheiros e tanques coletivos, além de fotos do imóvel que permitissem sua identificação e a verificação da possibilidade de reabilitar e reformar o edifício. Na pesquisa socioeconômica (amostral), algumas características da moradia eram explicitadas, tais como existência de janelas, divisórias, tipo de chuveiro, custos ligados à moradia - aluguel, água, luz, taxas, moradia anterior, percurso migratório do chefe, local de trabalho, transporte, renda e escolaridade.

Em São Paulo, são nove Setores Básicos de Intervenção e suas áreas diretas de influência englobam um complexo território da capital, denominado Área Central, definido pelo perímetro do Centro Histórico (Sé e República) e pelos bairros do chamado Anel Intermediário (Santa Cecília, Bom Retiro, Consolação, Bela Vista, Liberdade, Cambuci, Pari, Brás, Belém e Mooca), com funções historicamente determinadas pelos usos industriais e de serviços especializados. A perímetro soma cerca de $44 \mathrm{~km}^{2}$ e uma população de 516.000 habitantes. Os dados pesquisados mostram que 2/3 das famílias vivem com renda per capita de até 2 salários mínimos. A proporção dos chefes de família com carteira de trabalho assinada é considerável (36,5\%), embora a maioria tenha inserção precária: $45 \%$ dos chefes de família são trabalhadores informais; em torno de $86 \%$ dos chefes trabalham, e apenas $14 \%$ não o fazem. O aluguel consome grande parte da parcela do rendimento familiar, 43,5\% do ingresso das famílias com até 3 salários mínimos. Esse porcentual sobe para 48,5\%, quando a ele se somam as despesas com água, luz, impostos e outras taxas. A rotatividade entre os cortiços é alta: a metade dos chefes vive no atual domicílio há menos de 1 ano, e morava, anteriormente, em outro cortiço ou pensão (53,5\% dos chefes). 


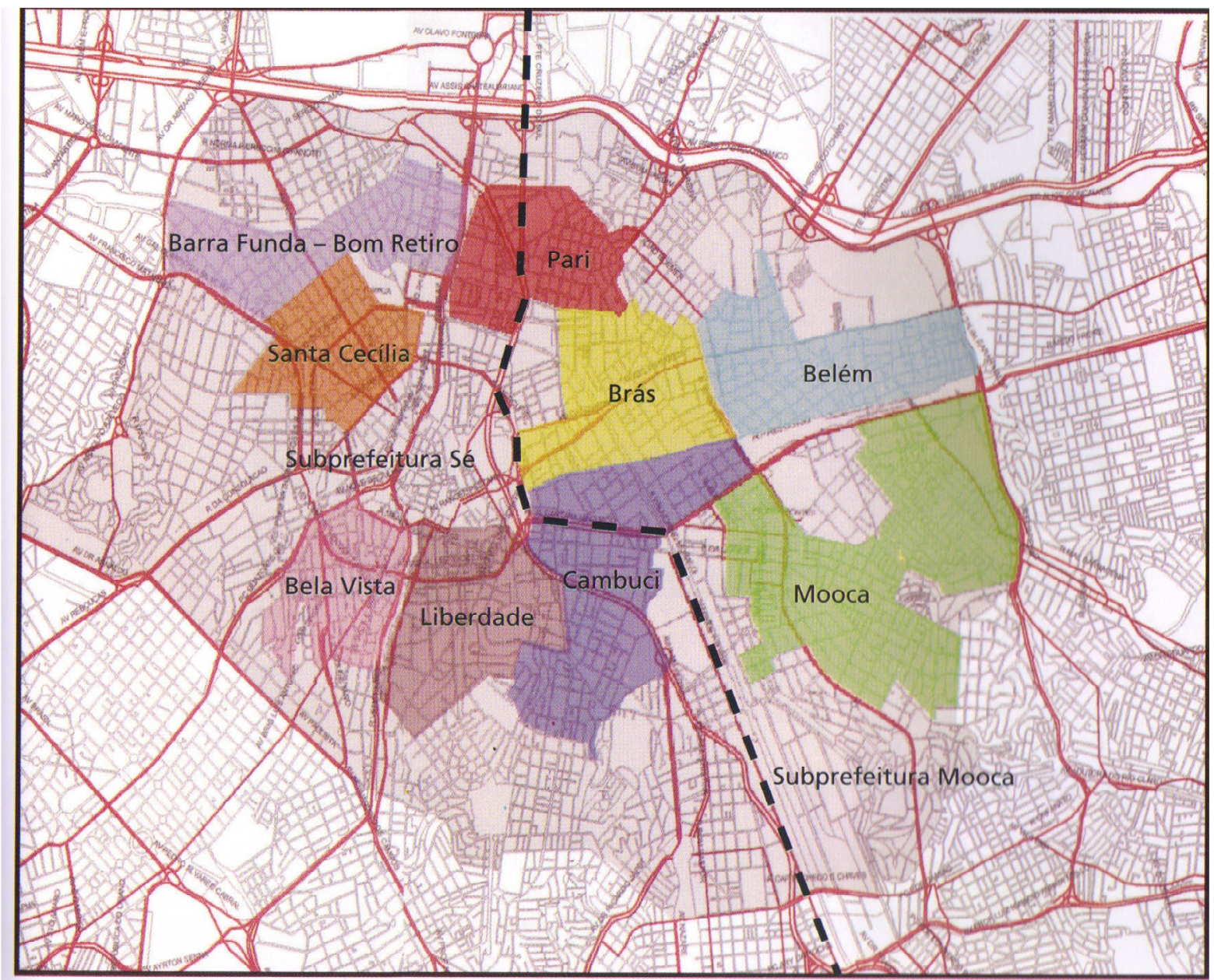

Área de Influência estimada $=44 \mathrm{~km}^{2}$

Área da Subprefeitura da Sé $=26,2 \mathrm{~km}^{2}-100 \%$ desta na área de influência.

Área da Subprefeitura da Mooca $=35,2 \mathrm{~km}^{2}$ - aproximadamente $50 \%$ desta na área de influência.

População estimada da Área de Influência $=516.000$ habitantes.

Figura 6 - Setores Básicos de Intervenção e Áreas de Influência do Programa de Atuação em Cortiços (PAC) no município de São Paulo

FONTE: SÂO PAULO - CDHU-SEADE (2002: p.15)

Em Santos, outra cidade abordada pelo PAC, tem-se um setor básico de intervenção, que corresponde ao bairro Paquetá, que atualmente constitui uma Zeis 3, definida pelo Plano Diretor Municipal, a fim de "facilitar o acesso formal da população de baixa renda ao solo urbanizado, regularizando os assentamentos que possam receber melhoras e criando mecanismos que estimulem a colocação de vazios urbanos para a produção de habitação popular" (SÃO PAULO, 2002a: p.6). A pesquisa socioeconômica restringiu-se às famílias residentes em 40 imóveis localizados no perímetro adotado. Este município traz ainda o desafio de implantação de empreendimentos mais complexos, pois busca compatibilizar 0 atendimento 
habitacional de baixa renda com a recuperação dos imóveis encortiçados, com legislação de preservação municipal.

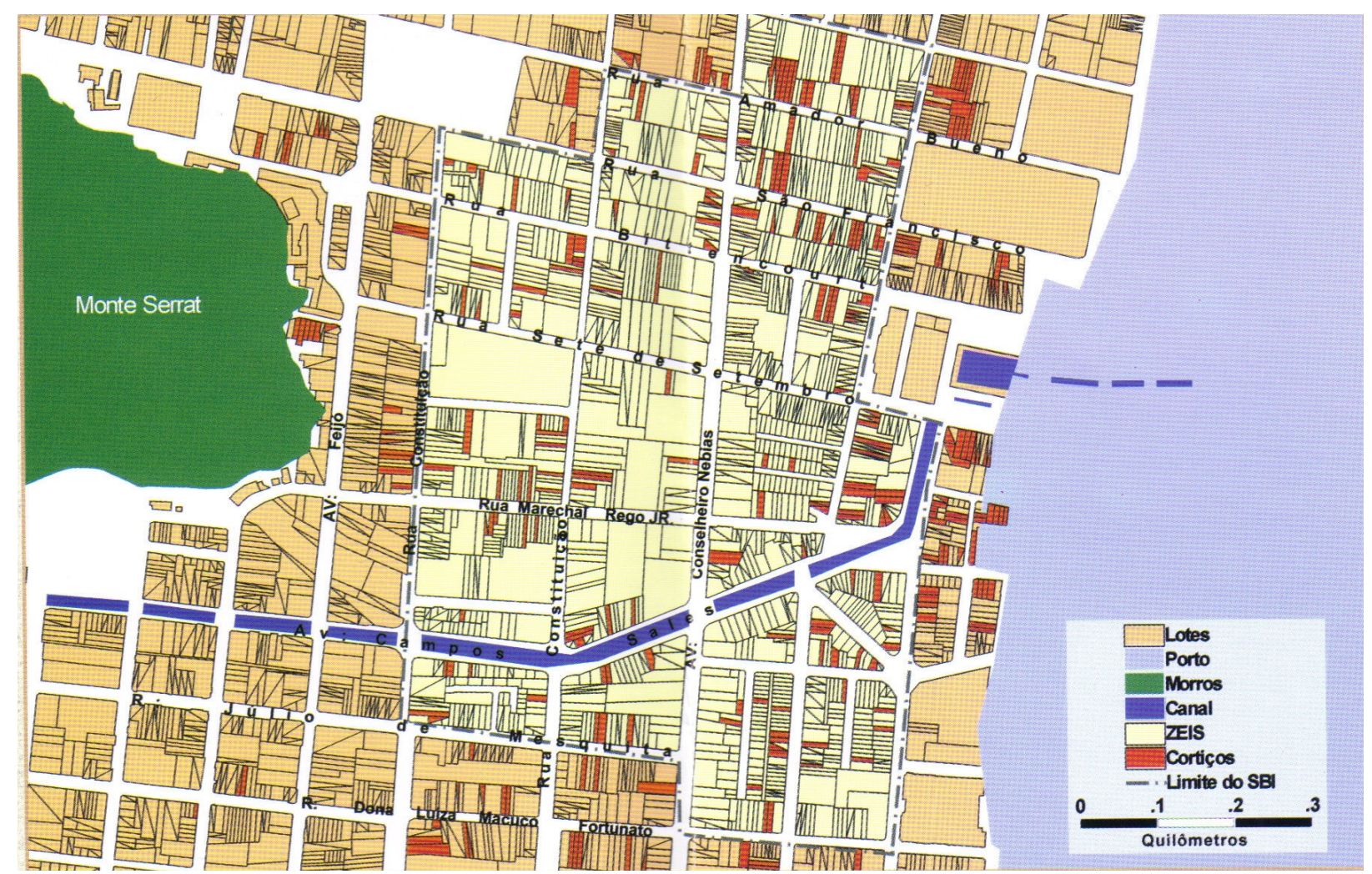

Figura 7 - Setor Básico de Intervenção e Áreas de Influência do Programa de Atuação em Cortiços (PAC) no município de Santos

FONTE: SÃO PAULO - CDHU-SEADE (2002: p.15)

O atendimento a famílias de média renda pelo programa, tanto no município de São Paulo como no de Santos, foi resultado de acordo com a equipe do BID e, resume-se, ao fornecimento de um subsídio para as primeiras famílias que quisessem adquirir um imóvel residencial requalificado na área central. Os objetivos esperados eram o de atrair outras famílias de classe média para a área central, ampliar a demanda por imóveis e reduzir a vacância. Além dos incentivos financeiros diretos, estavam previstos incentivos fiscais, como por exemplo, a isenção do IPTU.

Durante a gestão de Marta Suplicy, em São Paulo, é recuperado o convênio com o governo francês que tem forte influência na formulação dos programas e ações citados, entendendo que a experiência francesa se constitui um cenário histórico, social, político e cultural diferente da realidade brasileira, mas que apresenta reflexões 
importantes para o entendimento da temática da habitação de interesse social em áreas centrais, aliando esta discussão a de patrimônio histórico ${ }^{39}$.

Em São Paulo, diversos eventos - palestras, seminários, workshops e até um curso especializado - serviram à divulgação da concepção, formulação e operação da experiência francesa. Destaca-se aí a parceria entre a Sehab - Secretaria de Habitação e o LabHab - Laboratório de Habitação e Assentamentos Humanos da FAUUSP, como organizador e propiciador de tais eventos, principalmente através da pesquisadora Helena Menna Barreto Silva.

Um desses eventos foi o Encontro Técnico "Habitação no Centro de São Paulo: como viabilizar essa idéia?". Em agosto de 2000, o encontro foi realizado com objetivo de reunir diversos setores ligados à produção e ao financiamento da habitação social para discutir a questão da Área Central de São Paulo. O Programa de Arrendamento Residencial (PAR) foi um dos principais pontos de debate ao lado da demanda habitacional específica e das possibilidades e limites para uma política habitacional, tanto nos aspectos urbanísticos, como nos arquitetônicos e técnico-construtivos. A coordenação geral do curso foi realizado pela pesquisadora do LabHab, Helena Menna Barreto Silva, com patrocínio da Caixa Econômica Federal.

O Curso "Gestão de Programas de Reabilitação Urbano", em novembro de 2000, foi baseado no programa anual de formação contínua da École Nationale des Ponts et Chausses (ENPC) sobre gestão de operações de reabilitação urbana em bairros antigos na América Latina. A coordenação geral do curso também foi realizada pela pesquisadora do LabHab, Helena Menna Barreto Silva.

O Seminário Internacional "Gestão da Terra Urbana e Habitação de Interesse Social" foi outro evento promovido ainda em 2000, que debateu, em um dos grupos de

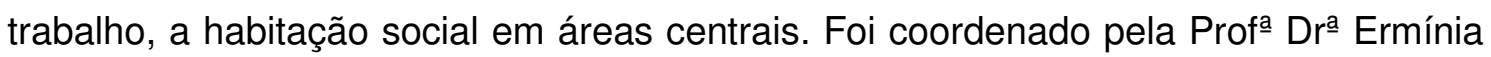
Maricato. As questões discutidas foram: Qual a viabilidade social e econômica da

\footnotetext{
${ }^{39}$ Os modos de urbanização dessa época - mistura de grandes conjuntos e de construção anárquica de casas - vão ser radicalmente questionados pela primeira crise do petróleo em meados da década de 1970. Ao mesmo tempo, o empobrecimento dos tecidos antigos e seu despovoamento com o risco do surgimento de guetos no centro da cidade, fizeram os administradores públicos reagirem, lançando uma política experimental de reconquista dos centros nas cidades médias: entre 1974 e 1976, foram assinados 90 contratos entre o Estado e as cidades. Essa política contratual foi entendida como "um laboratório de novas concepções do urbanismo, da habitação, do patrimônio, monumental ou 'banal', e o espaço de formação de novas equipes políticas e profissionais" (BOUCHE, Nancy. A Reabilitação na França: instrumentos e procedimentos. In: Gestão de Programas de Reabilitação Urbana. São Paulo: Ecole Nationale des Ponts et Chaussées (ENPC), Federação Nacional das Associações Pact-Arim e LABHAB/FAUUSP, 2000. Tradução de Helena Menna Barreto Silva. Mensagem recebida por cmcarq@hotmail.com em 13 de novembro de 2007).
} 
ampliação do uso habitacional das áreas centrais, especialmente com habitação social?; Quais os condicionantes legais e urbanísticos para seu sucesso?; Qual é a melhor solução entre derrubar e reconstruir ou restaurar e adaptar os edifícios existentes?; A indústria de componentes construtivos e da construção civil está preparada para esse tipo de intervenção em larga escala? Durante os debates veio à tona, novamente, a experiência francesa de reabilitação urbana. As críticas surgidas foram referentes, sobretudo, à necessidade cada vez maior de subsídios públicos do governo francês para a população pobre, ou seja, o enorme custo fiscal de manter a população nos locais de origem. No que tange às experiências latino-americanas, o único exemplo citado foi o da Cidade do México, onde, após o terremoto de 1985, foram construídas 45.000 unidades na Área Central, que contou com um alto investimento externo e com a participação da população e de diversos setores.

A Comissão de estudos sobre Habitação na Área Central de São Paulo foi constituída em 2001, pela Prefeitura Municipal de São Paulo, sob a presidência do arquiteto urbanista e, então, vereador Nabil Bonduki. As sessões públicas abordaram temas como: problemas e perspectivas da Área Central; experiências relevantes de habitação; condições de vida nos cortiços e ocupações; política urbana e política habitacional no Centro; programas e recursos existentes; potencial de ocupação do Centro e legislação urbanística incidente; reforma e reciclagem de edificações e legislação incidente. As conclusões e os encaminhamentos foram sistematizados em um "Relatório Final" publicado em setembro de 2001.

Outro evento foi o Seminário Internacional "Reabilitação de edifícios para uso habitacional: tecnologia da reforma", realizado no final de 2001, que discutiu as inovações tecnológicas necessárias para o setor da construção civil a fim de viabilizar a reabilitação de edifícios para o uso habitacional a custos compatíveis com um programa de larga escala. A CEF apresentou o, então recém criado, "Programa de Revitalização de Sítios Históricos", que também contou com a cooperação do governo francês. A experiência francesa foi exposta nos seguintes aspectos: importância da reabilitação na economia francesa; questões relativas à concepção e coordenação de projeto; metodologia para elaboração de diagnóstico sobre construções antigas e instrumentos utilizados para avaliar a viabilidade das operações de reabilitação de edifícios.

O Workshop "PRIH - Perímetros de Reabilitação Integrada do Habitat", foi organizado em 2002, pela Sehab, o Procentro e a Cohab com o objetivo de apresentar 
os resultados da primeira parte de um levantamento detalhado de seis regiões definidas na Área Central de São Paulo, dentro das quais foram definidos perímetros de intervenção que seriam objeto de propostas na segunda fase do trabalho. Em seguida a Sehab realizou o Workshop "Locação Social”, como parte dos acordos de cooperação técnica da PMSP com os governos da França, Holanda e Itália. O objetivo do encontro foi apresentar as experiências de locação social nestes países, apontando a estrutura administrativa, os aspectos normativos e financeiros e a gestão condominial.

O "Laboratório de Diagnóstico" e o "Laboratório de Obras de Reabilitação" ocorreram em 2002, no âmbito da cooperação técnica com o governo francês. Os encontros tinham por objetivo discutir métodos de avaliação de edifícios, considerando o conhecimento dos principais problemas e a conveniência ou não de uma reforma, e os critérios de projeto para redução de custos com qualidade, e ainda discutir programas e controle de obras de reforma com base em experiências francesas e brasileiras.

Ainda em 2002, foi realizado o Seminário "Estatuto da Cidade e Habitação na Área Central de São Paulo”, pelo LabHab (Laboratório de Habitação e Assentamentos Humanos da FAUUSP) em parceria com a Sehab, para discutir os aspectos do Estatuto da Cidade que podem interferir em uma política habitacional para a Área Central de São Paulo. Pode-se verificar a consolidação de um discurso consensual sobre a importância da ampliação da moradia social em áreas centrais, em virtude, principalmente, de seu esvaziamento populacional. A possibilidade, que o Estatuto da Cidade apresenta, de transformar o uso ocioso dos imóveis em uso efetivo por meio da aplicação do parcelamento, edificação ou utilização compulsórios, também foi apontada como um avanço. O Plano Diretor (que ainda não estava aprovado) avançaria com as propostas de definição de ZEIS para regiões vazias e subutilizadas da Área Central. A disponibilidade de recursos financeiros para programas de habitação na Área Central através do PAR (CEF) e do PAC (CDHU/ BID), foi apontada como outro avanço fundamental. No tocante às intervenções habitacionais, surgiu, em contraposição às intervenções pontuais em prédios isolados, o conceito inovador de trabalho integrado (urbanístico, habitacional, social e jurídico) em conjunto de quadras. Um limitador apontado foi a dificuldade de se adquirir imóveis na área central dentro do valor estipulado pelos órgãos e programas financiadores, que dependia em grande parte do processo de requalificação urbana da Área Central, que resulta na incapacidade de utilização dos recursos que estão disponíveis. 
O Seminário Internacional "Reabilitação do centro de São Paulo: novas oportunidades para o mercado imobiliário", em junho de 2003, foi realizado pela PMSP, pelo Secovi e pelo Sinduscon. A CEF fez uma exposição sobre a reabilitação urbana em áreas centrais destacando sua estratégia para o desenvolvimento urbano. Como antecedentes foram apresentadas as experiências de Olinda, nos anos 80, e de Salvador e Rio de janeiro, nos anos 90. E ainda, os estudos de viabilidade elaborados pelo Programa de Revitalização de Sítios Históricos, para convênios firmados com as cidades de São Luís, Belém, Recife, Salvador, Natal, Porto Alegre e João Pessoa. Foi ressaltado ainda a necessidade de formulação, por parte do Ministério das Cidades, de uma Política Nacional de Reabilitação de Áreas Centrais. Jean Jacques Remy, engenheiro francês falou sobre a experiência francesa e concluiu reafirmando que a reabilitação é um novo campo de atuação no ramo da construção civil, que os recursos necessários são menores do que para as construções novas, que o impacto sobre as comunidades é reduzido e a geração de empregos é superior às das construções novas. O seminário ainda contou com a palestra "As políticas de habitação social, hoje, na França", ministrada por Marie Thérèse Drosso Ferial, pesquisadora do Institut d'urbanisme de Paris expôs diversas críticas, dentre elas o fato da habitação ser um assunto de competência exclusiva do Governo Central apesar da descentralização implantada desde 1980. 


\subsection{Promoção Pública de Habitação de Interesse Social em áreas centrais - possibilidades e limites}

A intervenção pública em áreas centrais encontra amplas possibilidades associadas ao significado histórico e cultural da área e aos interesses de setores do capital, sobretudo imobiliário, comercial e financeiro. Há, entretanto, fatores de naturezas diversas que dificultam e colocam limites às ações ligadas ao provimento de habitação de interesse social em tais áreas.

Um desses limites é de ordem ideológico-cultural. Conforme a conceituação de Chauí (1981: p.21), ideologia seria aquela versão da realidade social dada pela classe dominante com vistas a facilitar a dominação. "Por intermédio da ideologia, a classe dominante legitima as condições sociais de exploração e de dominação, fazendo que pareçam verdadeiras e justas" (VILLAÇA, 1998: p.343). Dentro da perspectiva do urbano, naturaliza-se a idéia de que aos pobres está reservada a periferia - a "outra cidade" - onde a infra-estrutura é precária ou inexistente. Isso justifica os investimentos em áreas ocupadas pela classe de renda alta, pois assim, estariam investindo na "cidade". Conforme Lefebvre (2001: p. 143), "a sociedade capitalista tende a separar umas das outras suas próprias condições. O efeito de separação é inerente a essa sociedade, á sua eficácia". Ou seja, "quando separa elementos da população, tal segregação (a segregação sócio-espacial) pode ter vantagens para o capitalismo". Segundo Villaça,

[...] os homens não disputam enquanto 'indivíduos', mas enquanto classes, e essa disputa determinará a estrutura intra-urbana em qualquer modo de produção - não apenas no capitalismo - em qualquer sociedade de classes [...]. As camadas de alta renda controlam a produção do espaço urbano por meio de controle de três mecanismos: um de natureza econômica - o mercado, no fundamentalmente o mercado imobiliário; outro de natureza política: 0 controle do Estado, e, finalmente, através da ideologia" (VILLAÇA, 1998: p. 333 e 335)

Outra idéia que se dissemina é a de que o centro deslocou-se. Surgem os "novos centros" - em detrimento ao "Centro Velho" - mais adaptados às atuais necessidades do mundo globalizado. No entanto, o que de fato está mudando é a área da cidade provida de comércio e serviços voltados para a minoria - a classe dominante. Enquanto isso se reforça a idéia de que a deterioração do centro vem acontecendo por causa da presença da população de baixa renda 
O processo rotulado de deterioração pela idéia dominante refere-se ao estado de quase ruína em que são deixados muitos edifícios dos centros tradicionais, em virtude de seu abandono pelas camadas de alta renda, que produziram novos centros. Como o centro é uma área importante da metrópole, a classe dominante não pode assumir esse fato e precisa ocultá-lo, formulando uma versão que não comprometa sua posição de classe dominadora. Cria, então, a ideologia da 'deterioração', que é uma versão que 'naturaliza' o processo social [...] veiculando a idéia de que o que ocorria era um processo normal e inexorável, decorrente do envelhecimento do centro. É claro que a ideologia dominante procurou difundir a idéia de que, apesar dessa inexorabilidade, ela estava fazendo de tudo o que estivesse a seu alcance para 'salvar' o centro, para que esse fosse 'revitalizado' e voltasse a ser como antigamente (VILLAÇA, 1998: p.345).

Numa escala mais local, o preconceito e discriminação também atuam sobre o conceito ideológico de "habitação popular", que é constantemente aplicado na projetação e edificação das unidades habitacionais voltadas para as classes de baixa renda. Este conceito é dado como imutável, e acaba por distorcer e influenciar de modo difuso e direto a qualidade, a dimensão e a aparência das unidades habitacionais produzidas. É a ideologia de que a população de baixa renda só pode ter acesso à habitação barata, e que isso deve resultar necessariamente em unidades pequenas e de má qualidade construtiva - "normais" ou "coerentes" com as "condições em que vivemos".

[...] outra questão conceitual é a visão da moradia. Eu acho que por muito tempo nós trabalhamos (os técnicos, quem elaborava a política) com a idéia que moradia eram as quatro paredes. Então onde sai mais barato (onde dá para fazer quatro paredes melhor) é melhor. Aí quando você traz o conceito de que moradia é o direito à cidade [...]. Então você muda a visão. (depoimento de Luiz Kohara, Favela do Gato, engenheiro, PMSP, Sehab - Habi, gestão Marta Suplicy: apud Barros, 2002: p. 48)

\begin{abstract}
Eu acho que uma questão cultural que é violenta é o estigma que você tem da casa popular. [...] Uma pessoa nasce e já sabe que casa popular é um quadradinho com um triângulo em cima, e é tudo igual, colocado num terreno plano, sem árvores, sem nada. $E$ isso é no Brasil inteiro, em qualquer lugar que você vá, você reconhece o conjunto popular, e reconhece por falta dessa qualidade, por essa falta de inteligência colocada no projeto. [...] Então é uma falácia, mas que a gente topa, porque a única voz que empurra é o mercado. (Depoimento de Reginaldo Ronconi, arquiteto, FUNAPS Comunitário, gestão Luíza Erundina: apud Barros, 2002: p. 53)
\end{abstract}

No caso da área central destacam-se os movimentos populares de luta por terra e moradia que atuam pressionando a sociedade para que se alterem suas formas 
de organização social que resultam na atual condição de sobrevivência das famílias de baixa renda. Essa atuação se dá através de variadas formas de ação política. São atos públicos, seminários, marchas, festas, panfletagens, incursões nos meios de comunicação e ocupações de imóveis que não cumprem sua função social. A população encortiçada é principal alvo de programas habitacionais da região central. Ainda assim, enfrentam questões específicas inerentes à sua inserção social. Estas especificidades os condicionam às posturas de imobilismo e de desarticulação coletiva para a luta pela moradia de qualidade no centro. A falta de identidade faz com que muitos não se considerem parte integrante dos "espaços centrais" da cidade. Se sentem ilegais, ocupando um espaço sem respaldo legal.

[...] A construção individual não está completa. Se não tenho completa minha individualidade, é muito difícil que se chegue a uma construção coletiva. Isso passa pela formação político-ideológica. As pessoas devem aprender a se defender e não a serem defendidas. [...] Cidadania e dignidade não é um prato de comida ou um cigarro que se dá por aí, não. [...] É como um emprego, que a partir dele pode se conseguir comida, roupas. Deve haver um esforço pessoal. (Depoimento de Gegê, liderança popular, MMC, apud Barros, 2002: p. 64)

A especulação e o "entesouramento"40 são outras duas formas ideológicas que atuam sobre os programas públicos de habitação de forma direta, muitas vezes até impedindo a realização de um empreendimento habitacional. Há exemplos da inviabilização da produção devido à especulação de um proprietário de imóvel, que demanda do poder público quantia muito acima de seu valor real, à espera de sua valorização. Isto se dá também por causa de investimentos (que raramente voltam-se para a questão habitacional), e junto aos proprietários dos próprios imóveis encortiçados que perpetuam a existência deste tipo de habitação de baixíssima qualidade, garantindo lucratividade com a máxima subdivisão de cada lote e da moradia em diversas unidades habitacionais e à falta de despesas com impostos e com a manutenção do imóvel.

A isto se soma, ainda, a inércia operacional do poder público, que não acompanha a dinâmica da sociedade e que torna difícil, por exemplo, enxergar a diversidade de um centro, as especificidades de cada prédio, de cada projeto, as reais

\footnotetext{
40 "Ato de entesourar. Juntar, ajuntar, acumular, amontoar (dinheiro, riqueza, etc.). 2. Arrecadar, guardar em tesouro ou como um tesouro (dinheiro, bens, etc.): 'vendo, pela primeira vez na vida, dinheiro grosso, achou de aviso entesourá-lo para se resquardar de futuros apertos)" (HOLANDA, Aurélio B. de. "Novo Dicionário Aurélio". 1975: p. 534)
} 
e diversificadas necessidades dos moradores. Essa cultura de manutenção do status quo funcional, dito como eficiente, torna-se uma barreira à busca de novas soluções.

A segunda categoria de limites são os políticos, que se referem ao "jogo de forças políticas", disputas entre as diferentes legendas partidárias, que ocorrem durante as gestões e mais intensamente nos períodos eleitorais. A parcela da população que sustenta a idéia "pobre = periferia" vai sustentar ações que sejam coerentes com esta concepção de cidade. Neste sentido, as ações governamentais que fugirem a essa regra acabam por perder o apoio de parte da população.

Outro limite, submetido igualmente à correlação de forças, refere-se à legislação, ou instrumentos urbanísticos, que enfrentam pesada burocracia para serem implementadas. Tal dificuldade pode ser interpretada como inoperância governamental. As normas acabam se defasando, e não se aplicando mais à realidade das cidades. A falta de fiscalização, que é uma função básica atribuída por lei à administração pública municipal, acaba por perpetuar condições de irregularidades em relação às edificações e de ilegalidade com relação à locação. Segundo Piccini,

[...] A fiscalização depende de vontade política e de um programa de ação que possa dar conta de uma quantidade tão grande de edificações irregulares. Por outro lado, se os proprietários forem multados de forma generalizada, provocar-se-ia uma falta de habitações na cidade, sem que exista um estoque de moradias pronto para a substituição. A conclusão de que é melhor deixar como está, dada a complexidade do problema e a falta de fiscalização, levam à tolerância que, por sua vez, beneficia o profícuo mercado clandestino de aluguel (PICCINI, in: SANTOS et al (org), 2002: p. 37)

Outra questão é a desarticulação entre os níveis de governo (municipal, estadual e federal). Ações sobrepõem-se, repetem-se estudos, e trabalhos são feitos e refeitos. As bases de dados formuladas não incidem sobre o mesmo perímetro de estudo e diferentes conceituações são utilizadas. O resultado é que os programas elaborados acabam mostrando-se incompatíveis à realidade da população ao qual se destinam.

Existem ainda dificuldades sócio-econômicas. Segundo as lideranças dos movimentos populares e assessores técnicos, a renda de parte das famílias para a compra da moradia é tão baixa, que o parcelamento de seu pagamento por 25 anos é insuficiente. Desta forma, reivindicam-se políticas de subsídio e alternativas de acesso à moradia para estas famílias. Os programas existentes são voltados para famílias que têm de três a seis salários mínimos. Não existem programas para quem ganha até três 
salários, assim como para os muitos trabalhos informais, sem comprovação em carteira de trabalho. A solução para estes é a ilegalidade, como se dá nos cortiços, ocupações, ruas, etc.

Entretanto, não apenas de dificuldades de acesso ao sistema de crédito padecem as famílias de menos de três salários mínimos. Mesmo que tenham sido 'aprovadas' pela análise sócio-econômica de concessão de crédito, elas têm problemas em quitar as prestações de sua unidade, e também em executar manutenções nas unidades. A conseqüência, muitas vezes última, é a venda ou repasse do imóvel acessado, ainda que os contratos de Compra e Venda, e/ou Arrendamento, não permitam ou reconheçam essa prática: "a miséria é que faz as pessoas precisarem vender, 'comer' os apartamento." (Verônica Krol, liderança popular, integrante do Fórum dos Cortiços. In: SILVA, H., 2000: p. 51).

A gentrificação, que se refere às questões tangentes à ação do capital imobiliário e ao deslocamento forçado, ou a expulsão das populações de baixa renda dos centros históricos em 'recuperação', é outra preocupação. Investimentos privados, como, por exemplo, os resultantes da "Operação Urbana Centro", em São Paulo "criada para promover a recuperação da área central da cidade, tornando-a novamente atraente para investimentos imobiliários, comerciais, turísticos e culturais ${ }^{, 41}$ - acabam elevando os preços do mercado, e isso acaba inviabilizando os projetos, que se tornam pontuais, favorecendo os grandes especuladores, as grandes imobiliárias, as grandes construtoras.

A questão da localização, neste sentido, é outro aspecto importante de ser destacado na identificação dos limites à produção pública de habitação de interesse social em áreas centrais, uma vez que o 'alto preço' dos imóveis existentes nas áreas centrais é apontado enquanto um problema para que de fato se viabilize programas neste sentido. Segundo Villaça (1978: p. 12), "na cidade de economia de mercado, a localização é a mercadoria mais importante no mercado imobiliário". A influência do mercado imobiliário na localização das pessoas na cidade é decisiva, pois dita o local em que cada classe social poderá se estabelecer:

[...] as pessoas de diferentes faixas de renda decidem sua localização na cidade conforme o preço que podem pagar pelos imóveis, pela moradia. O preço dos terrenos ou prédios é mais caro em áreas atrativas para uma demanda de maior renda, e mais baixo em zonas menos atrativas (SILVA, H., 2002: p. 41).

\footnotetext{
${ }^{41}$ In: http://portal.prefeitura.sp.gov.br
} 
Ainda como caracterização e compreensão da localização enquanto mercadoria, e seu poder ditatorial sobre a espacialização das pessoas de diferentes classes sociais, Villaça afirma que:

[...] quando uma pessoa compra um terreno ela compra duas mercadorias. Um pedaço de terra e uma localização. A primeira muda pouco ou quase nada, e no caso das localizações urbanas tem pouca importância. [...] A segunda está em constante transformação, independentemente do fato do proprietário do terreno nela fazer ou não melhorias ou edifícios. [...] Essas características fazem do espaço - ou a terra quanto base material das localizações - uma mercadoria altamente disputada, presa fácil da especulação e finalmente, inclusive pela indisponibilidade de sua distribuição equitativa, o produto cuja divisão melhor exibe a luta de classes (VILLAÇA, 1978: p.49).

Existem também limites de ordem jurídico-legais, que se referem àqueles impostos pela legislação e pelo sistema jurídico em vigor. São problemas para a aprovação de projetos arquitetônicos, que resolveriam de melhor forma questões relativas à falta de qualidade projetual das unidades; à forma de ocupação dos terrenos, que resultariam em menor custo das moradias; aos entraves na gestão da máquina pública, que segue procedimentos muitas vezes morosos e descabidos às práticas de produção habitacional, bem como pelos processos de litígio fundiário que se estendem por anos a fio, enquanto o imóvel 'aguarda' uma decisão judicial. 0 resultado, muitas vezes, são projetos quase que padronizados, centralizados em seus lotes e impossibilitados de se adequarem às características do entorno.

A discussão também se estende sobre a impossibilidade de se projetar edifícios de uso misto, onde a função comercial poderia gerar renda para a própria manutenção do edifício. Isso acontece porque os edifícios voltados para famílias de baixa renda produzidos pelos programas públicos têm que, inicialmente, pertencer ao Estado, estando desta forma, submetidos à legislação incidente sobre a propriedade privada. Problemas também são identificados quanto às irregularidades fundiárias: dívidas, desvios, e litígios de propriedade - dívidas impagáveis de IPTU e comprovação incipiente de propriedade.

Há também limites técnicos-profissionais, que dizem respeito à formação profissional nas universidades que não dá ênfase ao preparo para o trabalho com reciclagem de edifícios, imóveis para locação social, empreitadas em mutirão autogerido ou em autogestão. Em geral não está voltada para o trabalho com políticas 
públicas, muito menos para lidar com movimentos populares de luta por terra e moradia.

A tecnologia em si tem se mostrado um limite dependente, pois é fato que o país dispõe de técnicas suficientes para o enfrentamento das questões tocantes à construção civil, mas é também fato que por diversas vezes elas não são aplicadas. Verificam-se dificuldades técnicas para intervenções em edificações já existentes, ou a reciclagem de edifícios para a habitação, devido ao costume das empresas construtoras de apenas edificar novas unidades e pouco reutilizar imóveis já erguidos.

[...] Como os prédios são na maioria bem antigos, da década de 40, 50 , em alguns sequer tínhamos a planta original dele lá atrás. Tínhamos que fazer um trabalho de prospecção. Alguns lugares, com alguma planta antiga de estrutura que você tinha, achava que tinha um pilar passando num lugar; quando você ia mexer, não era lá, aparecia em outro lugar" (Depoimento de Marco Antonio, técnico da CEF, PAR, gestão Luiz Inácio Lula da Silva, apud Barros, 2003: p.132).

Existem também limites de gestão dos programas, que dizem respeito à ausência de uma estrutura de gestão, organizada, integrada às demais ações e secretarias de governo, com base de dados acessíveis e constantemente atualizados. Identifica-se, ainda, a necessidade de consolidação de um estoque de terras públicas no centro, suficientes para que a escala da produção habitacional passe das intervenções pontuais a uma produção massiva.

Há, finalmente, limites arquitetônicos, que acabam sendo decorrentes de todos os limites anteriormente identificados. Trata-se da materialização possível aglutinadora de todas as dificuldades mapeadas. O projeto de arquitetura sozinho não tem o poder de 'milagrosamente' resolver a falta de qualidade e a insuficiência quantitativa das moradias populares no centro: "nossos projetistas, ao invés de aumentar o banheiro, querem diminuir o nenê!" (PASTERNAK, in: SILVA, H., 2000: p. 45).

Entende-se que tais limites entrecruzam-se a todo o momento, deflagrando a necessidade de trabalhar a questão de forma interdisciplinar, numa discussão ampla para a produção de um verdadeiro ideário que permeie programas habitacionais integrados à reabilitação de áreas centrais efetivamente. 


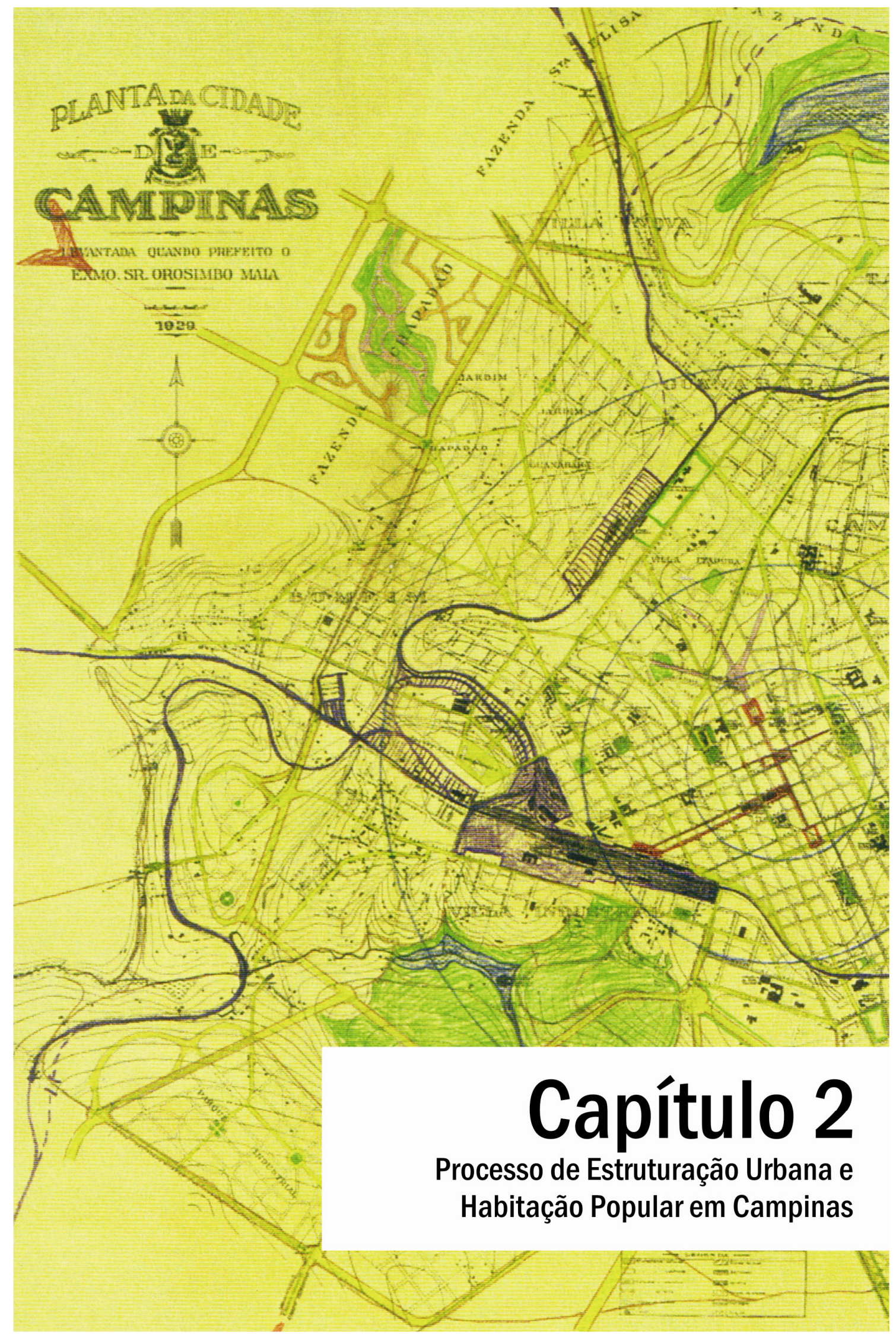




\subsection{A emergência dos cortiços}

O primeiro indício da formação de Campinas se dá em 1774, através de um documento que apontava diretrizes para a formação de um novo núcleo sob cargo e responsabilidade de Barreto Leme, com definições de dimensões de quadras, ruas e disposição de casas. Elevada à condição de vila - "Vila de São Carlos" - em 1797, nesta área que foi doada por Barreto Leme e que se tratava de parte de uma sesmaria que the foi concedida pelo governo, foram instaladas a igreja, a sede da freguesia, a praça e as primeiras quadras, segundo as orientações recebidas. Segundo Badaró,

permanecem, ainda hoje, impressos no desenho da cidade, vestígios da localização do caminho dos Guaiazes, do pouso e do núcleo que se desenvolveu ao seu redor, representados pelas sinuosidades e desarranjos que fogem ao traçado retilíneo e ortogonal que iria caracterizar as expansões organizadas da área urbana até os princípios do século XX (BADARÓ, 1996: p.18).

Para Santos,

os precisos documentos da fundação da freguesia e ereção da vila da atual cidade de Campinas, [...] revelam a singularidade do arruamento da parte mais central de seu rossio, originalmente iluminista e historicamente laicizado. A configuração particular de sua trama urbana, no interior do perímetro convencional da meia légua em quadra, destacou-a morfologicamente da maioria das cidades brasileiras. Quanto ao espaço restante do antigo quadrado, este seria recortado em uma figura geométrica qualquer, resultante da apropriação privada destas terras, agora valorizadas pela nova ordem capitalista da cidade (SANTOS, 2002: p.161).

O núcleo deixa de ser centro religioso de uma pequena comunidade rural, dedicada à atividades de subsistência e à policultura rudimentar (com destaque para o milho), e se desenvolve a partir da introdução da lavoura de cana-de-açúcar, com modificação de hábitos e surgimento de uma elite que assumiria a hegemonia política e social da vila. A economia, agora pautada na monocultura em larga escala e na mão-de-obra escrava, abrangia, em 1822, cerca de 3.800 habitantes, e em 1836, cerca de 6.890 habitantes (BERGÓ, apud BADARÓ, 1996: p. 22).

As casas térreas que predominavam na freguesia, pequenas e toscas, construídas de pau-a-pique, dispostas nos cantos das quadras, com amplos muros de barro vermelho ao longo do alinhamento, cederiam lugar para o casario mais denso, seqüência de portas e janelas, interrompida por poucos casarões, e alguns sobrados construídos com taipa de pilão. [...] As atividades de produção e subsistência se processavam no engenho. Despontava a vida na cidade, onde os senhores de engenho construíam casas para 
os fins de semana, desempenhavam suas atribuições administrativas e religiosas, dispunham de um incipiente comércio de tecidos, roupas e utensílios domésticos, importados de Portugal e contavam com artífices dedicados à arte de construir e equipar suas moradias (BADARÓ, 1996: p.22).

A rápida expansão da cultura do café na região de Campinas e noroeste paulista, a partir de 1840, trazia destaque considerável à região, com a Vila de São Carlos sendo elevada à categoria de cidade, em 1842. O pesquisador Ari V. Fernandes destaca que, "entre 1836 e 1854, a produção do Vale do Paraíba cresceu cinco vezes, enquanto a da região de Campinas aumentou dez vezes" (MORSE, 1970, apud FERNANDES, 2004: p. 80). Neste momento a vida na Capital se apresentava atrativa à nova elite urbana, que com a facilidade de locomoção permitida pela ferrovia no último quartel do século XIX - cujo traçado definirá a ocupação urbana e sua dinâmica regional até 1950 -, "podia agora gozar de uma vida mais confortável e mais animada na Capital, continuando com estreito contato com suas fazendas" (MORSE, 1970: p.233-234). Porém, na mesma época, Campinas já abrigava manufaturas, estabelecimentos comerciais e instituições importantes, exercendo atração semelhante.

Na década de 1860, a região já era a maior produtora do estado e Campinas o mais rico município paulista. Na década seguinte, a cidade comportava mais de 300 cafeicultores e exportava 1,3 milhão de arrobas de café, sendo conhecida como a capital agrícola da província. O crescimento populacional também era destacado, passando a ser a mais populosa da província, com 33 mil indivíduos suplantando a capital, que tinha 26 mil (CANO \& BRANDÃO, 2002: p.101).

É inaugurada, em 1868, a Companhia Paulista de Estradas de Ferro, que liga Campinas a Jundiaí e faz o entroncamento com a São Paulo Railway, conectando Campinas a São Paulo e Santos. Realizando a conexão com o interior do estado, em 1875, é inaugurada a Companhia Mogiana e, posteriormente, a Sorocabana. "Assim, o Oeste interligava-se ao porto e à capital e, Campinas, até então considerada "boca do sertão' passou a ser o maior entroncamento ferroviário do Império" (CANO \& BRANDÃO, 2002: p.101).

Desta maneira, como pólo de uma vasta região sobre a qual se estrutura o complexo cafeeiro paulista, a cidade se abre. Em 1872, são registrados 33 mil habitantes no município, sendo 13 mil brancos e 20 mil negros e mulatos, dos quais 
metade compunha a população urbana, "dedicando-se às obras de edificação, abertura de ruas, implantação de estradas de ferro e serviços domésticos das famílias abastadas" (BERGÓ, apud BADARÓ, 1996: p.26). Na ocasião, a população urbana totalizava mais de 14 mil habitantes.

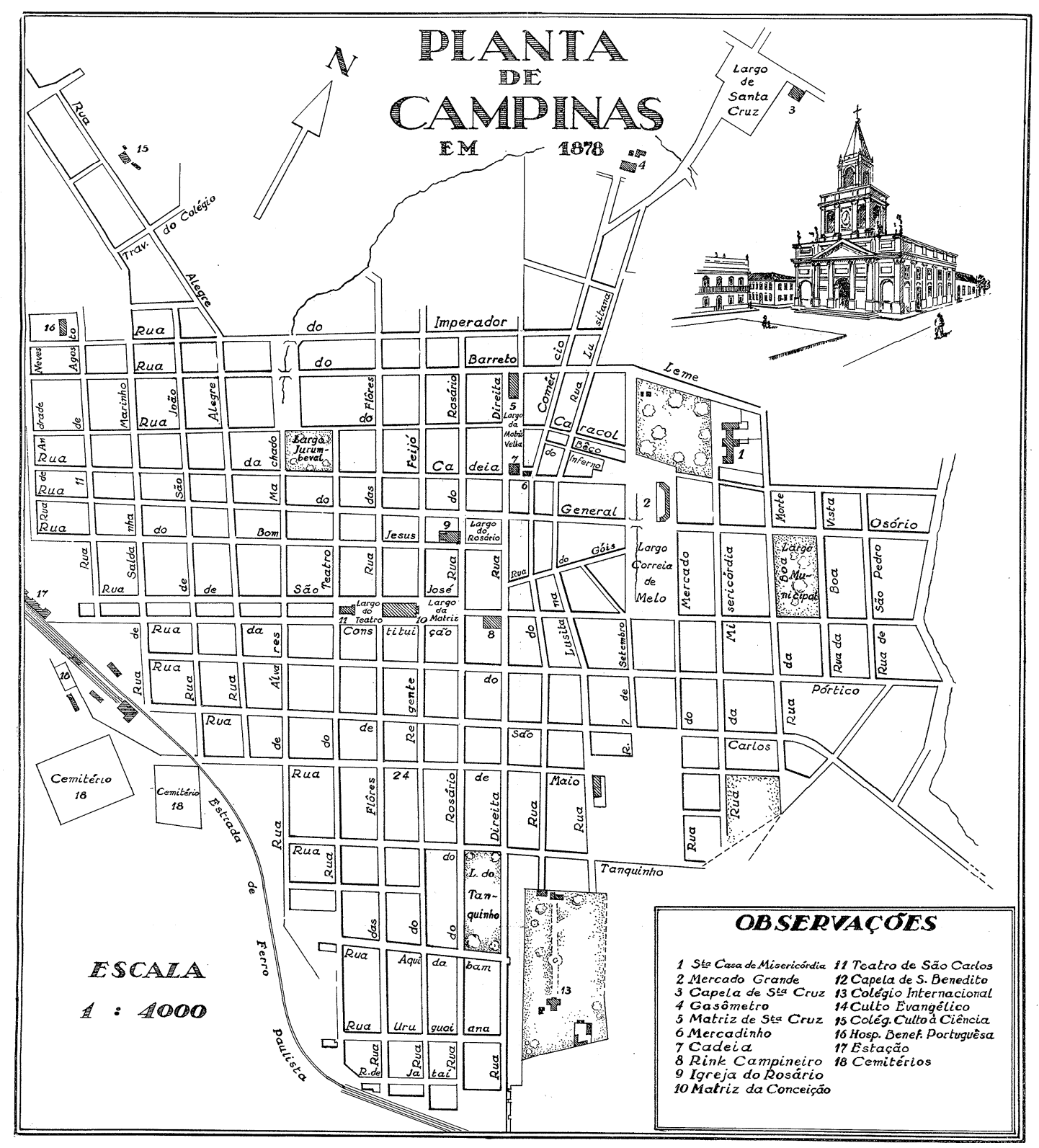

Figura 8 - Mapa de Campinas em 1878

Fonte: informação pessoal. Caderno de Subsídios PD Campinas 2006. CD-rom disponibilizado por Ari V. Fernandes durante entrevista realizada em 22 de janeiro de 2008.

A relação entre o aumento da população e a valorização dos terrenos dá início ao processo de diferenciação espacial e funcional do tecido urbano, através da agregação de novos bairros ao centro, como Ponte Preta, Bonfim, Cambuí e 
Guanabara. Casas comerciais e "pontos de café" instalam-se na antiga Rua São José (atual Rua 13 de Maio), eixo de comunicação direta entre o centro primitivo e a estação.

No Largo da estação e nas primeiras quadras das ruas adjacentes instalaram-se o comércio atacadista de secos e molhados e importantes hotéis. Abriram-se a Avenida Andrade Neves e Boulevard Itapura (paralelo à Estação Mogiana) cujas larguras contrastavam com a das estreitas ruas existentes até então (BADARÓ, 1996: p. 27).

Assim também, a localização das oficinas das companhias ferroviárias nos terrenos anexos aos armazéns de carga e descarga, induz à formação de um bairro operário em suas imediações, a Vila Industrial, que acabou por determinar a "vocação proletária da porção sudoeste da cidade"(BADARÓ, 1996: p.30). Conforme Santos,

as operações de reforma e melhoramentos das cidades no âmbito do café - contribuições da pioneira engenharia nacional - marcariam os esforços de constituição gerais para uma cidade capitalista, mas, em Campinas, estiveram sobredeterminadas pelos interesses fundiários da elite local (2002: p.162).

Neste período, foram montadas na cidade empresas concessionárias de serviços públicos como as Companhias Campineiras de "lluminação a Gaz" (1872), de "lluminação e Fôrça" (1911), de "Carris de Ferro" (operadora dos bondes de tração animal, em 1878) e mais tarde a de "Tração, Luz e Fôrça" (1911).

Diversas obras de infra-estrutura também são realizadas para o abastecimento de água encanada via chafarizes públicos (1875). Instalações hospitalares são criadas, como: "Santa Casa da Misericórdia", "Irmãos Penteado" (1876), "Beneficência Portuguesa" (1879) e "Circolo Italiani Uniti" - atual Casa de Saúde de Campinas (1884). Também são fundados o "Colégio Culto à Ciência" (1874), o "Hipódromo Campineiro" (1887) e a "Estação Agronômica" (atual Instituto Agronômico). Muitas casas bancárias são implantadas nesta mesma época, confirmando a importância que a cidade adquirira com a economia cafeeira. A partir de 1886, a capital paulista se fortalece como a "metrópole do café" e a cidade de Campinas se beneficia com sua importante posição, como nó de transportes e comunicações.

Campinas atinge, em 1888, cerca de 20 mil habitantes na área urbana e 0 município totaliza cerca de 50 mil (BERGÓ, apud BADARÓ, 1996: p.30). A cidade passaria a disputar a hegemonia política urbana da província nos primeiros anos após a Proclamação da República, em 1889, mas a epidemia de febre amarela que atingiu 
Campinas na década seguinte (1890-1903), comprometeu de forma irreversível tais pretensões $^{42}$. A população do município decresce para 5 mil habitantes, devido à inúmeras mortes e ao intenso êxodo que se processa. Muitas famílias deixaram a cidade e desocuparam suas casas. Algumas foram aproveitadas para instalação de serviços de saúde. Outras foram divididas ou simplesmente ocupadas coletivamente por famílias de trabalhadores, imigrantes ou antigos escravos, gerando cortiços.

Neste contexto, a moradia urbana do pobre passou a ser considerada problema pelas autoridades. A proliferação dos cortiços, aliado aos demais problemas sociais que se refletiam na cidade, incidiu numa discussão sobre a moradia dos trabalhadores de baixa-renda, com elaboração de planos e ações que tratassem à questão. A erradicação violenta e agressiva dos cortiços, pautada em justificativas higienistas, camuflava outros objetivos de ordem social e econômica.

No Brasil, como na Europa, o tema da habitação insalubre encontrou espaço central numa forma de problematizar a cidade centrada em questões de segurança e higiene. [...] A moradia urbana, de um modo geral, era vista como um ambiente prejudicial à saúde de seus moradores, enquanto a habitação do pobre era entendida como uma ameaça mais ampla, tanto à saúde quanto à moralidade e à produção (CORREIA, 2004: p.03).

Devido às epidemias, a Intendência Municipal realiza diversas obras de saneamento básico e a "Companhia Campineira de Águas e Esgotos" conclui as obras para abastecimento predial de água e destinação de esgotos. O governo estadual instala a Comissão de Saneamento do Estado, que, sob a orientação do engenheiro Saturnino de Brito, elabora e implementa planos para o abastecimento e distribuição de água, além de planos para a coleta e destinação do lixo e do esgoto, e realiza a canalização de córregos e drenagem de charcos. Outra medida foi a criação, em 1895, da Lei $n^{\circ} 43$, o primeiro Código de Construções da cidade, no qual se estabelecem normas de higiene e segurança para obras no perímetro urbano, com definição de dimensões mínimas para recuos, áreas de iluminação e ventilação, cômodos e janelas, altura dos pavimentos e dos pisos assoalhados, espessura de paredes e seus revestimentos, além de exigências de ligação de esgoto e captação de águas pluviais. O perímetro estabelecido para controle não abrangia a Vila Industrial, o Fundão (Ponte Preta), o Frontão (Cambuí), parte do Guanabara e do Bonfim, que, segundo Badaró, eram "nascentes arrabaldes populares"(BADARÓ, 1996: p.31).

${ }^{42}$ Principalmente pela perda de $50 \%$ de população, sendo $17 \%$ relativos aos casos de óbito e $33 \%$ por emigração (FERNANDES, 2004: p.102). 
Desenvolve-se, portanto, [...] a idéia de plano e de reforma urbana, por meio de obras de saneamento e embelezamento, com contraditório caráter de atingir a melhoria social através da elevação do padrão moral das classes populares. [...] A epidemia, ambientada nos espaços de grande densidade de ocupação e de precária infraestrutura de saneamento básico, alimentava socialmente 0 argumento político de remoção de camadas socialmente marginalizadas para a periferia mais distante (SANTOS, 2002, p.187).

Campinas readquire, somente em 1900, a população urbana de 19 mil habitantes. "A cidade tivera sua economia bastante prejudicada, perdendo a primazia do desenvolvimento industrial, então incipiente, que acabou por concentrar-se em São Paulo. Ganhou, entretanto, em organização e saneamento" (BADARÓ, 1996: p. 32).

O setor industrial desenvolve-se, neste momento, produzindo não somente implementos agrícolas - exigido pelo capital da economia cafeeira -, mas também fios, tecidos, peças de vestuário, além de produtos químicos e laticínios. De acordo com a análise de Semeghini (2006), o desenvolvimento e urbanização de Campinas são exemplos, no território paulista, de cidade que se desenvolve a partir da economia cafeeira. Não é caso único, mas se diferencia das demais cidades devido a algumas questões, como: a diversidade de sua base produtiva, tanto na agricultura quanto nas atividades urbanas, a função de centralidade que a cidade adquire precocemente, e o papel de interface entre capital e interior, devido a sua posição estratégica no território. Segundo Badaró,

diversos fatores contribuíram para a implantação de indústrias: a proximidade de São Paulo, as facilidades de transporte proporcionadas pelo entroncamento ferroviário já instalado, a introdução da energia elétrica como força motriz (1905), as boas condições da infra-estrutura em geral e a excelência da vida urbana proporcionada pela cidade (BADARÓ, 1996: p.34).

Campinas se desenvolve, tendo como principal vetor de crescimento a Estação e Armazéns da Cia. Paulista. A área comercial ocupa os Largos do Rosário e da Catedral, estende-se pelas ruas General Osório, Bom Jesus (atual Campos Sales), São José (atual 13 de Maio) e depois prolonga-se pela Rua da Constituição (Costa Aguiar), até a ferrovia. $O$ aspecto comercial da cidade se fortalece devido às estradas de ferro e à sua função de pólo regional. As indústrias e operários optam pelas áreas periféricas, mais baratas, promovendo o desenvolvimento dos arrabaldes, principalmente em locais próximos às saídas da cidade. Desenvolvem-se os bairros do Fundão (Ponte Preta), ao sul - na saída para São Paulo -, o Frontão (Cambuí), ao 
leste, e o bairro Guanabara, formado por diversas chácaras, no sentido noroeste. Diante desse avanço no crescimento da cidade, os terrenos são valorizados e passam a ser vendidos em hasta pública.

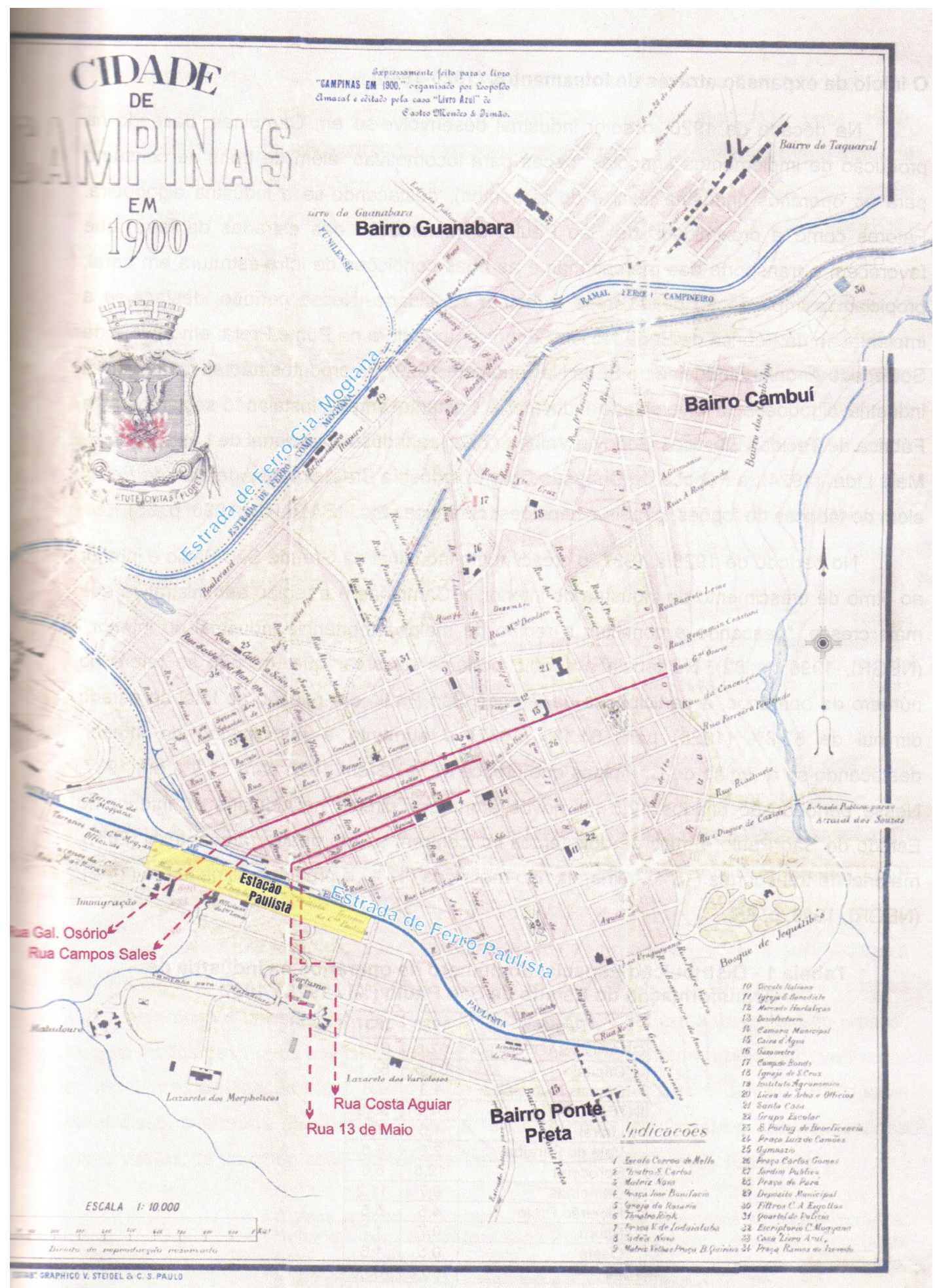

Figura 9 - Mapa de Campinas em 1900

Fonte: informação pessoal. Caderno de Subsídios PD Campinas 2006. CD-rom disponibilizado por Ari V. Fernandes durante entrevista realizada em 22 de janeiro de 2008. 
Em 1912, a população urbana de Campinas é de cerca de 38 mil habitantes e, em 1920, atinge cerca de 50 mil habitantes. No entanto, essa população ocupa o perímetro urbano constituído no século XIX, área que tinha sido esvaziada por causa da febre amarela e, posteriormente, valorizada e reurbanizada. Assim, a área urbana não sofre grande expansão e a prefeitura investe principalmente em pavimentação e drenagem. As obras de Saturnino de Brito são retomadas: realizam-se drenagens e canalizações de córregos, além de prolongamentos de avenidas (BADARÓ, 1996, p. 23-30, 33-43). O traçado da cidade se expressa, sobretudo, de forma retilínea, ortogonal e contínua, começando a ultrapassar a Estrada de Ferro Mogiana, ao norte, e a Estrada de Ferro Paulista, ao sul. Neste período, de 1900 até meados da década de 1920, portanto, o desenvolvimento da área urbanizada de Campinas é pouco significativo, não apresentando áreas não adjacentes às constituídas no período anterior.

Santos ressalta, no entanto,

um novo ator como classe social, em cujas mãos estaria o monopólio na cidade. $O$ fazendeiro agora também poderia ser capitalista, comerciante e banqueiro, e manter suas grandes propriedades agrícolas orbitando ao redor do centro da cidade, capitalizado materialmente por eles mesmos (SANTOS, 2002: p.163-164).

Estes, através das empresas privadas que dirigiam - concessionárias de privilégios para a realização de obras e serviços de água e saneamento, iluminação e transporte elétrico - atuariam no sentido de configurar a reforma da cidade de acordo com os interesses capitalistas de localização de suas propriedades. 


\subsection{A ação do estado e a regulamentação diante das moradias coletivas no centro}

O período que compreende as décadas de 1920 a 1940, é marcado, em Campinas, pelo desenvolvimento industrial em diversos setores - principalmente na década de 1920, com o capital gerado, sobretudo, pela economia cafeeira - chegando a apresentar índices de crescimento industrial maiores que a Grande São Paulo, no período de 1928 a 1937 (NEGRI, 1996: p. 85).

Associado ao desenvolvimento industrial verifica-se em Campinas "a intensificação do processo de urbanização, a valorização dos terrenos existentes e a grande expansão da área urbana edificável, ocorrida após meados dos anos 20, sob auspícios da especulação imobiliária" (BADARÓ, 1996: p.36). A expansão verificada por volta de 1925 está relacionada à necessidade de novas habitações, à mobilidade proporcionada pelos automóveis e ao emprego seguro de capitais. Conforme Badaró, "entrava em cena a especulação imobiliária, como protagonista principal do novo desenho da cidade. O lote urbano, entendido como mercadoria, iria presidir a expansão urbana ao sabor dos interesses do capital bem adiante da demanda efetiva da população" (BADARÓ, 1996: p.36).

Segundo Fernandes (informação pessoal ${ }^{43}$ ), devido ao crash de 1929, ocorre a transferência de propriedades que faz nascer uma nova geração de fazendeiros. Muitos dos, até então, fazendeiros, representantes da elite campineira, se vêem obrigados a vender suas propriedades para migrantes (árabes, italianos, etc.) em função da crise financeira instaurada.

Cano \& Brandão (2002: p.124), também evidenciam que, principalmente a partir da década de 1930, a expansão urbana de Campinas está relacionada à dinâmica econômica e aos interesses da elite local. A crise da economia cafeeira, de 1929, torna viável a transformação do proprietário rural em urbano e o investimento na construção civil é uma possibilidade segura de transferir capital de um ramo para outro. A partir dessa nova forma de expansão urbana, na qual muitos dos novos bairros, projetados por empresas privadas, passam a surgir fora do perímetro urbanizado, sem planejamento e infra-estrutura, verifica-se a necessidade de obras viárias, de pavimentação, de transportes e de esgoto. Surgem parcelamentos distantes e desconectados da área já urbanizada - denominados "Parque Industrial" e "São Bernardo" - que oferecem ao mercado lotes mais baratos, dentro das

\footnotetext{
${ }^{43}$ FERNANDES, Ari V. Entrevista concedida em 22 de janeiro de 2008.
} 
possibilidades econômicas dos operários, embora estejam situados à grandes distâncias e apresentem precária infra-estrutura urbana (BADARÓ, 1996: p.30-36, 111-115).

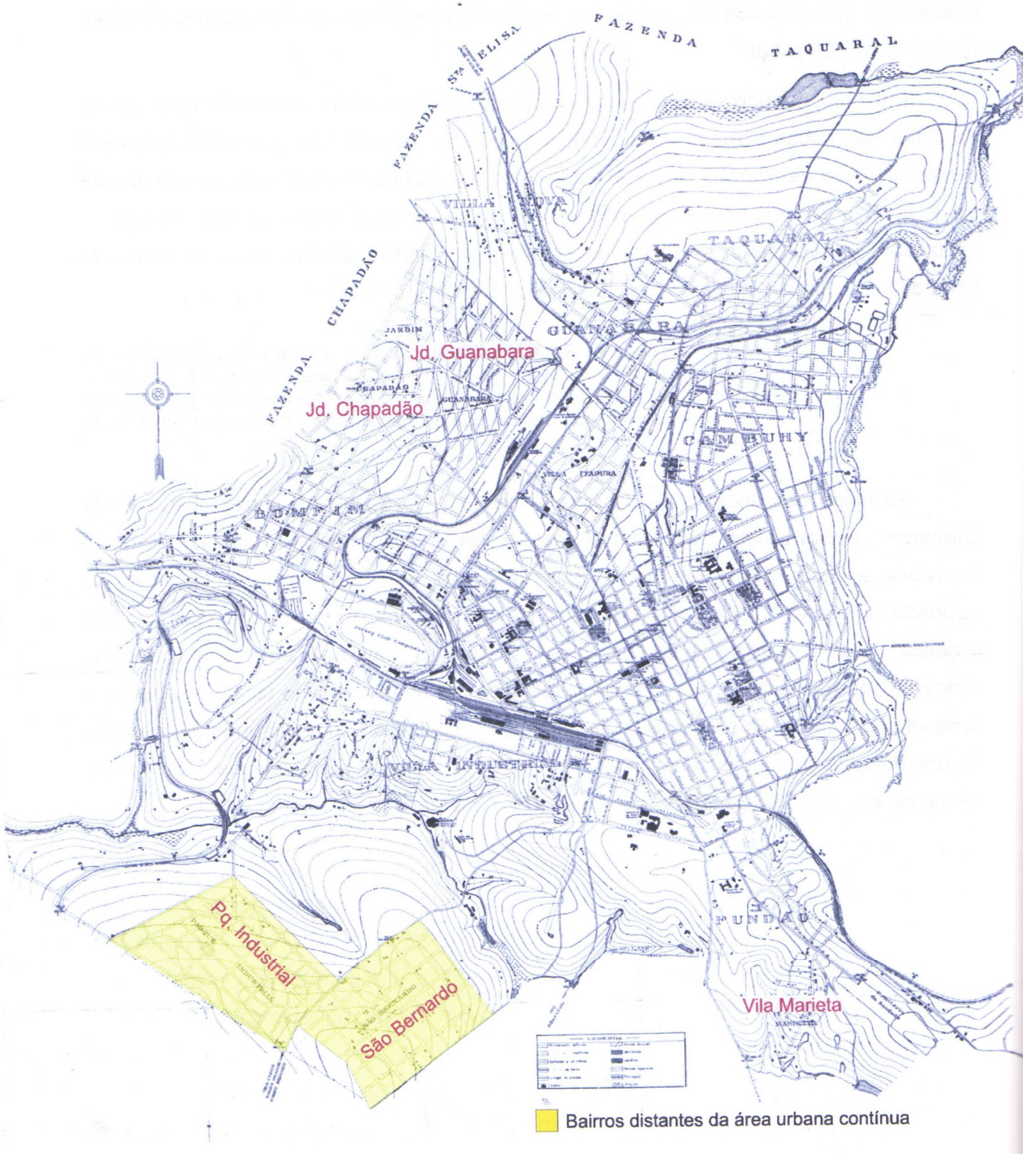

Figura 10 - Mapa de Campinas em 1929

Fonte: informação pessoal. Caderno de Subsídios PD Campinas 2006. CD-rom disponibilizado por Ari V. Fernandes durante entrevista realizada em 22 de janeiro de 2008. 
Segundo Badaró,

a área urbana que entre 1900 e 1925 praticamente não se expandira, limitando seu crescimento a poucas complementações viárias executadas pela municipalidade, sofreu a partir de 1925, um notável alargamento, duplicando em alguns anos suas dimensões (BADARÓ, 1996: p.35).

Em 1934, o Código de Construções, aprovado pelo Decreto Municipal №76, divide a cidade em quatro zonas concêntricas de acordo com a sua localização e determina o perímetro dos distritos de Valinhos, Arraial dos Sousas, Rebouças, Cosmópolis, Joaquim Egídio e José Paulino. De acordo com a legislação, as vilas (agrupamentos de casas industriais) somente poderiam ser implantadas na $2^{\underline{a}}$ zona. Já os estabelecimentos perigosos ou insalubres seriam permitidos na $4^{a}$ zona, também chamada zona de transição. Tanto a Vila São Bernardo, quanto o Parque Industrial, bairros não contíguos à área urbanizada até então, situam-se na $3^{\text {a }}$ zona. No entanto, como a legislação estabelecia que, conforme os terrenos da $4^{\underline{a}}$ zona e da zona rural fossem vendidos, estes passariam automaticamente à $3^{\text {a }}$ zona, as áreas rurais eram facilmente transformadas em urbanas. O decreto, portanto, não oferecia mecanismos de regulação da expansão urbana horizontal. Estabelecem-se também, no código, parâmetros para construções, arruamentos e divisão de terreno em lotes. Segundo Santos,

o conjunto de artigos deste código de obras perpassava todas as determinações de produção do espaço da cidade, desde as mais gerais da infra-estrutura, como arruamentos e canalização de bacias hidrográficas, até as mais específicas do lote e da arquitetura (SANTOS, 2002: p.272).

Esse decreto é bastante abrangente, contendo uma ampla regulamentação sobre divisão de terrenos em lotes e arruamentos, normas para construção, além de regras específicas para casas populares. Para a abertura de vias, deveriam ser seguidas exigências de largura e disposição de acordo com insolação, ventilação, esgotos sanitários e águas pluviais, além de considerar o fator trânsito, a altura dos edifícios e a forma. As ruas deveriam ser complementares às já existentes ou aprovadas pelo município. A largura da via, assim como o uso permitido, dependia da categoria em que se enquadrava ${ }^{44}$.

\footnotetext{
44 As vias públicas foram classificadas em: vias de grande comunicação, ou "artérias de luxo", ou avenidas (mais de $20 \mathrm{~m}$ de largura); ruas principais (15 a 20m); ruas secundárias (12 a 15m); ruas de
} 
Instalou-se, pois, espontaneamente, uma nova estrutura rádio-anelarconcêntrica na qual o antigo centro urbano assumiria gradativamente características terciárias, com forte poder polarizador sobre a periferia residencial e industrial, com a qual passou a ligar-se, como outrora se ligava ao campo, isto é, através das mesmas vias radiais, antigas saídas da cidade (BADARÓ, 1996: p.58).

Em 1934, a população urbana de Campinas atinge cerca de 69 mil habitantes e a área urbana expande-se a partir da sucessão de áreas concêntricas, que se diferenciavam de acordo com o uso do solo. No entanto,

as iniciativas oficiais eram insuficientes para resolver a questão habitacional, agravada pelos baixos salários e pela intensidade da urbanização. Os cortiços, os porões e os velhos casarões da área central, em vias de demolição, continuaram como opção para aqueles que não se dispunham a transferir-se para a periferia ou não tinham recursos para a construção de sua própria moradia (BADARÓ, 1996: p. 112).

Assim, no ano de 1938, a Prefeitura Municipal instituiu uma comissão com a finalidade de realizar um levantamento sobre as condições dos cortiços existentes. Concluiu-se que os aluguéis pagos por estas insalubres habitações seriam suficientes para financiar a construção de moradias higiênicas e julgadas adequadas para cada família. O resultado do estudo foi publicado em $1939^{45}$ e levantou informações relevantes, conforme pode ser observado na tabela abaixo:

interesse local ou exclusivamente residenciais (8 a 12m); estradas na zona rural (mínimo de $13 \mathrm{~m}$ de largura) e caminhos da zona rural (mínimo de $8 \mathrm{~m}$ ). As avenidas e ruas principais não podem ser projetadas de modo que os lotes distem mais que $400 \mathrm{~m}$ delas e não podem ter declividade superior a $6 \%$. Nas outras vias, a declividade não pode ser superior a $8 \%$. Nas ruas secundárias e locais, o comprimento da via não pode ser superior a 30 vezes a sua largura e devem possuir alargamento para manobra a cada $150 \mathrm{~m}$, se não houver cruzamento. Nas ruas locais não podem ser implantados equipamentos comerciais

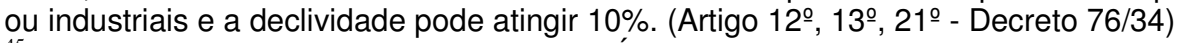

45 "Relatório Municipal de 1939". In: BADARÓ, 1996: p.59-60. 


\title{
TABELA 1 - Dados levantados pela Prefeitura Municipal de Campinas sobre os cortiços da cidade em 1938
}

Fonte: Relatório Municipal de 1939 (in: BADARÓ, 1996: p.112).

\begin{tabular}{|c|c|}
\hline Cortiços cadastrados & 74 \\
\hline Número de residências & 586 (famílias) \\
\hline Número de residentes & 2.321 (pessoas) \\
\hline Área Construída & $16.248 m^{2}$ \\
\hline Número de famílias por cortiço & 7,9 \\
\hline Número de pessoas por cortiço & 31,3 \\
\hline Área de construção por família & $27,7 m^{2}$ \\
\hline Número de pessoas por família & 4 \\
\hline Banheiro & $1 / 5,6$ famílias \\
\hline Pias & $1 / 17,2$ famílias \\
\hline Fogões & $1 / 1,9$ famílias \\
\hline Chuveiros & $1 / 11,5$ famílias \\
\hline Tanques & $1 / 3,5$ famílias \\
\hline
\end{tabular}

O levantamento tinha por objetivo subsidiar a aprovação de novas leis que favorecessem a construção, por parte da iniciativa privada, de habitações populares com o intuito de erradicar os cortiços do centro da cidade. Eram novos bairros, onde se construíam tipologias típicas de correr de casas populares, constituindo habitações unifamiliares em pequenos agrupamentos, por investidores associados à imobiliárias e construtores e, na sua maior parte, iriam se destinar ao aluguel.

\begin{abstract}
À época, o empenho da prefeitura foi traduzido no decreto lei oㅡ 82 de 26/12/1940 que reiterava a proibição de construir cortiços, mas estabelecia tipos habitacionais de padrão construtivo mínimo e padrão econômico mais acessível ao trabalhador. Regulamentava também a comercialização, interferindo nos preços e definindo critérios para vendas à prestação (BADARÓ, 1996: p. 113).
\end{abstract}

É importante notar que as leis que tratavam da habitação operária como "casos especiais" resultam da dificuldade de construí-las à luz do código de edificações de 1934, cujas exigências tornavam a construção mais cara e complexa. Apesar das leis especiais e do estímulo à construção de vilas e conjuntos operários, o total de unidades construídas entre 1940 e 1950 por institutos (IAPI, IAPC, etc.), pela Prefeitura, pela Fundação da Casa Popular, ou pela iniciativa privada somava apenas 963 unidades distribuídas em sete vilas no "centro expandido" da cidade atual (BADARÓ, 1996: p.114 e 115).

Foi neste momento de expansão e perspectiva de intensificação que se contratou, em 1934, Prestes Maia, para a elaboração de um plano para a cidade de Campinas. O plano, aprovado em 1938 sob o Ato no 118, com o nome Plano de 
Melhoramentos Urbanos, continha propostas principalmente voltadas à questão da acessibilidade e que reforçavam o processo de expansão verificado. À estrutura radialconcêntrica, o Plano associa as disposições para os futuros bairros residenciais e seus equipamentos, com referências especiais à área central da cidade, e disposições específicas para os bairros industriais e a localização futura de parques, praças e todos os edifícios públicos municipais. O desenho proposto estruturaria o alargamento gradual e futuro de mais algumas ruas, obedecendo à concepção dita perimetral, organizada por três anéis viários: interno, médio e externo. Os dois primeiros contornariam o centro histórico e bairros próximos a ele, amarrando as extremidades das avenidas centrais projetadas, e o último deles articularia os futuros parcelamentos das fazendas circunvizinhas (SANTOS, 2002: p.253-295).

A implantação das medidas propostas pelo Plano durou muitos anos, sendo completada em 1962, e pode ser dividida em duas fases. A primeira fase, de 1934 a 1955, está associada ao período em que a expansão industrial se processou de forma restrita pela insuficiência do setor de bens de produção. Engloba os trabalhos de concepção do plano e a lenta implantação de suas proposições. A segunda fase, de 1956 a 1962, corresponde à expansão industrial que se seguiu ao ingresso de investimentos estrangeiros, destinados à instalação do setor de bens de produção. Foi a fase mais intensa, precedida da revisão do Plano, aprovada em 1951. Acabou resumindo-se à obras viárias, não abordando as questões de expansão urbana, de arruamento e loteamento, que continuaram sob às normas do Código de Construções de 1934. 


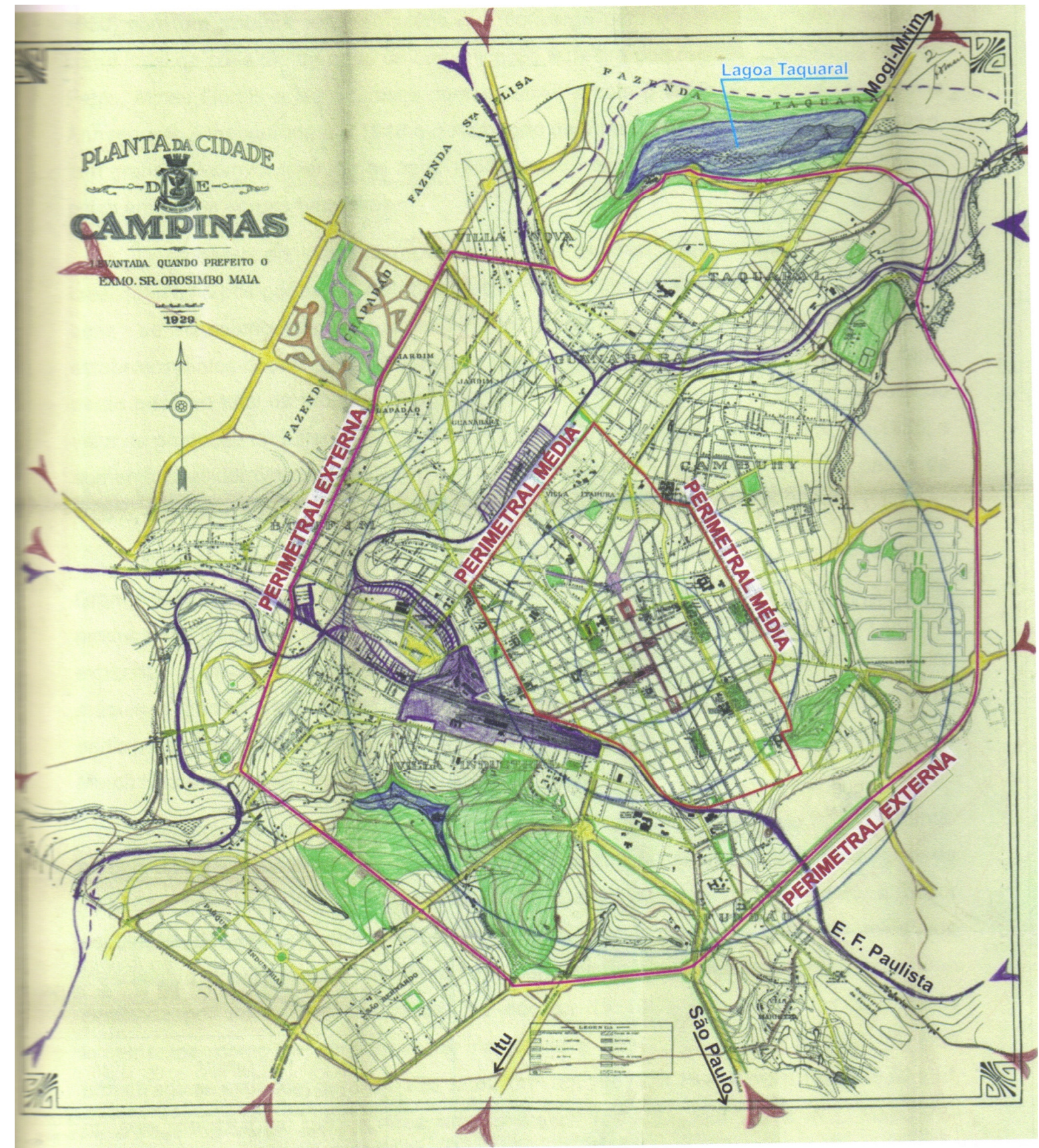

Figura 11 - Plano de Melhoramentos Urbanos de Prestes Maia (planta base da cidade de Campinas em 1929)

Fonte: informação pessoal. Caderno de Subsídios PD Campinas 2006. CD-rom disponibilizado por Ari V. Fernandes durante entrevista realizada em 22 de janeiro de 2008.

Em 1940, a população urbana de Campinas atinge cerca de 80 mil habitantes e a cidade se caracteriza por uma expansão contínua, exceto pelos bairros não contíguos localizados à sudoeste, implantados na década de 1930, não incorporados nesta fase de expansão - o "Parque Industrial" e a "Vila São Bernardo". 
Neste momento, embora continuasse presente, a questão sanitária passou para o segundo plano nos debates sobre habitação social e surgiram novos temas, condizentes com o projeto nacional-desenvolvimentista da era Vargas. Um desses temas é a noção da habitação vista como condição básica de reprodução da força de trabalho e, portanto, como fator econômico na estratégia de industrialização do país. Outro tema em evidência foi a idéia da habitação como elemento na formação ideológica, política e moral do trabalhador, e, portanto, decisiva na criação do "homem novo" e do "trabalhador-padrão" que o regime queria forjar como sua principal base de sustentação política.

Essa estratégia, que se estendeu pelas principais cidades brasileiras, respaldou a criação ou fortalecimento dos órgãos governamentais encarregados de produzir ou financiar a produção de habitações como as Carteiras Prediais dos Institutos de Aposentadoria e Pensões, e a Fundação da Casa Popular. Foi neste contexto que, em 1942, o governo interferiu no mercado de locação, congelando os aluguéis por meio da Lei do Inquilinato, que restringe os direitos dos proprietários de casas de aluguel. Difunde-se e incentiva-se o "sonho da casa própria" - uma nova abordagem do problema habitacional.

Os debates sobre habitação na década de 40 mostram que se tinha uma idéia bem exata do que era possível e das estratégias necessárias para se alcançar tais objetivos. A casa própria para os trabalhadores era um modelo de habitação que interessava às elites. Por outro lado, a ênfase na educação, que preferiria chamar de doutrinação, associada à desconsideração da carência econômica como principal obstáculo à aquisição dos imóveis pelos trabalhadores, mostra que se tentava incutir nestes a idéia de que, para se tornarem proprietários, dependiam apenas do próprio esforço. E como a solução mais viável pressupunha que o trabalhador teria de morar na zona rural ou periferia - em casa feita com as próprias mãos - em locais sem água encanada, sem coleta de esgoto, sem luz elétrica e apenas com um transporte coletivo capaz de levá-lo até o local de trabalho, era fundamental convencê-lo de que isto era melhor que a vida nas moradias coletivas situadas no centro da cidade (BONDUKI, 2004: p.96). 


\subsection{Consolidação de outras formas de habitação}

Foi diante desse contexto de periferização da cidade em prol do "sonho da casa própria" que se reforçou a intenção de alguns setores, entre os quais o capital imobiliário, de expulsar a população de baixa renda das áreas valorizadas centrais. 0 intenso processo de urbanização e a predominância do transporte rodoviário, configuraram, em Campinas, uma primeira periferia, que se formou entre 1950 e 1964 e que, em geral, tornou urbanas áreas já parceladas, mas irregulares.

À precariedade da moradia auto-construída soma-se a das condições urbanas. Os loteadores pouco ou nada investiram em infra-estrutura, até porque a maioria dos lotes foi adquirida pela classe média urbana da região e de fora dela, com o intuito de se obter uma reserva de valor, uma aplicação, ou para construção num futuro não definido. "A associação entre adquirir lotes nos novos loteamentos e morar próximo do emprego industrial, vale para uma minoria dos compradores, razão pela qual, muitos desses empreendimentos demoram décadas para serem ocupados e inúmeros lotes permanecem vazios até hoje" (FERNANDES, 2004: p.78).

O processo de industrialização do estado de São Paulo apresentou um notável crescimento no pós-guerra, com a implantação de importantes estabelecimentos do setor de bens de consumo durável, intermediário e de capital. Campinas possuía condições muito peculiares em termos de acessibilidade na década de 1950, com um sistema rodo-ferroviário que convergia para o município, consolidando-se como local de conexão de rotas de comunicação terrestre das regiões interioranas de São Paulo, Minas Gerais e Mato Grosso, com a capital São Paulo e o porto de Santos.

\footnotetext{
O traçado rodoviário contemporâneo expressa a rede de estradas do tempo do Império, que praticamente não foi alterada durante toda a República Velha. [...] Ao contrário das velhas estradas, não passariam por dentro de áreas urbanizadas, (porém, na prática), isso não aconteceu e o exemplo mais adequado é a Via Anhanguera, cuja ligação Campinas a São Paulo foi inaugurada no mês de dezembro de 1950. Passados quinze anos, todos os trechos próximos ao acesso das principais cidades já estavam urbanizados, surgiam diversas áreas de lotes industriais e os primeiros equipamentos terciários de porte (FERNANDES, 2004: p.77).
}

Segundo Semeghini (2006: p.40), "Campinas foi a única outra região além da Grande São Paulo que atraiu as novas indústrias em escala considerável". A indústria local se expandiu, apoiada na base de indústrias de equipamentos de beneficiamento 
e de máquinas, implantadas desde o início do século. A população também passou por um acentuado incremento na década de 1950, crescendo a taxas de 3,7\% ao ano. De 1950 a 1960, a população urbana passou de cerca de 100.466 para 186.808 habitantes. Em 1960, Campinas apresentou-se como a maior população do interior, representando $11,9 \%$ da população do estado.

Este acentuado crescimento econômico e populacional gerou demandas por novas áreas urbanas. Na década de 1950, foram aprovados 322 novos loteamentos (cf. Tabela 2). A área urbana se expandiu: em 1940 eram 12,32km²; em 1952, $39,16 \mathrm{~km}^{2}$ e em $1962,75,82 \mathrm{~km}^{2}$, ou seja, de 1940 a 1962 a área urbana cresceu mais de seis vezes.

TABELA 2 - Total de loteamentos aprovados em Campinas por década (1920-1990) Fonte: Prefeitura Municipal de Campinas

Secretaria de Planejamento (SEPLAN) - Coordenadoria de Parcelamento do Solo

\begin{tabular}{|c|c|}
\hline Década & $\begin{array}{c}\text { Total de } \\
\text { Loteamentos }\end{array}$ \\
\hline 1920 & 24 \\
\hline 1930 & 42 \\
\hline 1940 & 81 \\
\hline 1950 & 322 \\
\hline 1960 & 66 \\
\hline 1970 & 70 \\
\hline 1980 & 121 \\
\hline 1990 & 60 \\
\hline
\end{tabular}

Por volta de 1950, a área urbana atingiu a perimetral externa proposta no Plano de Melhoramentos Urbanos. "O Taquaral desenvolvia-se ao norte, em direção da lagoa, e do parque público às margens da perimetral externa, onde assumiria caráter residencial e sofisticado [...]" (BADARÓ, 1996: p.107). À leste, a expansão da cidade foi caracterizada pelas habitações de alto padrão, que se estenderam ao longo da Avenida Júlio de Mesquita, pelo Cambuí, contidas pelo Vale do Proença, que foi saneado e retificado pela Prefeitura, para permitir a ocupação do planalto além do córrego. À sudeste, os bairros do Bosque e do Proença desenvolveram-se rumo à perimetral externa. À noroeste, o Guanabara ultrapassou os trilhos da Mogiana, ocupando, de um lado, os jardins projetados na década de 1920 e, de outro, no entroncamento com a Estrada de Ferro Funilense, ocorreram implantações industriais que caracterizariam a Vila Nova. À nordeste, nas proximidades dos trilhos da Mogiana, foram implantadas indústrias e habitações proletárias e a Vila Itapura se adensou com caráter residencial, alterando a função industrial que a região adquirira nas primeiras 
décadas do século XX. As indústrias foram instaladas ao longo das ferrovias, de acordo com sugestões da prefeitura. Assim, desenvolveram-se com caráter industrial e proletário: Bonfim, a oeste; Vila Industrial| ${ }^{46}$, a sudoeste, e Ponte Preta ${ }^{47}$, ao Sul - todos cortados pelas estradas da Cia. Paulista. Destaca-se a implantação da Avenida Amoreiras, corredor de distribuição de tráfego para os bairros operários São Bernardo e Parque Industrial (implantados já na década de 1930) que se adensavam a sudoeste, ao lado do núcleo de casas construído pela Fundação da Casa Popular, reforçando o caráter popular de uso da área (BADARÓ, 1996: p.107-111).

Em 1951, a Lei no 640 traz uma revisão do Plano de Melhoramentos Urbanos de Prestes Maia, apresentando normas provisórias de zoneamento, porém ainda não trata da questão da expansão urbana horizontal. Segundo Badaró,

Os loteamentos continuam a ser regulados pelo Código de Obras de
1934 que se limitava às normas viárias e de parcelamento das
quadras. A ausência de diretrizes que estabelecessem direções
preferenciais para o desenvolvimento da cidade, definissem áreas a
serem preservadas para agricultura e estipulassem obrigações para
os loteadores, quanto à execução da infra-estrutura urbana, iria
deixar aberto o campo para nova expansão indiscriminada de
loteamentos que ocorreria [...] com grande intensidade, nos anos
seguintes (BADARÓ, 1996: p.121).

Em 1957, através da Lei Municipal no 1786, acrescentou-se ao loteador o encargo de realizar os serviços: redes de águas, canalização dos cursos de água, galeria de águas pluviais, demarcações com marcos de concreto e terraplanagem das ruas, quando necessário.

A partir de 1959, os loteamentos dentro e fora do perímetro urbano passaram a ser regulados pelo novo Código de Obras, que estabeleceu zonas diferenciadas, através de perímetros disciplinadores do crescimento urbano horizontal que eram formados por: áreas de distritos; vilas, bairros ou povoados; áreas dos loteamentos já aprovados; e áreas remanescentes e adjacentes às citadas anteriormente, incluindo as vias e estradas. A prefeitura elaborou, então, um plano racional para a extensão dos serviços públicos.

O perímetro subdividiu-se em perímetro urbano e suburbano, e toda área não circunscrita nesse perímetro passou a pertencer à zona rural do município. Os

\footnotetext{
${ }^{46}$ Destinada a um parque público no Plano de Melhoramentos.

${ }^{47}$ A Ponte Preta abrange diversos núcleos proletários: Vila Carmela Dutra, Vila da Cia. Paulista, Vila Elza, Vila Maria e Vila Marieta.
} 
loteadores passaram a ter a obrigação de construir a rede de luz domiciliar, a rede de água, a rede de esgoto, as galerias para captação de águas pluviais e deveriam pavimentar as ruas e avenidas preferenciais, de forma a ligar o loteamento a uma via pública oficial, respeitando as condições topográficas existentes.

Considerando as tendências já manifestas, o Código de Obras de 1959 mapeou a área central dividindo-a em zonas funcionais - ZC1 e ZC2 - que se destacam pela permissividade dos coeficientes de aproveitamento (podia-se construir 8 e 6 vezes, respectivamente, a área do terreno). É neste momento que se deu a segunda fase de implantação do Plano de Melhoramentos Urbanos de Prestes Maia.

Segundo Badaró, em 1953, a área loteada de Campinas comportaria três vezes a população existente. Essa grande oferta de lotes

\begin{abstract}
colocaria em risco a distribuição organizada da população que tenderia a ocupar, de modo lento e rarefeito, um vasto território urbano, dificultando e onerando a realização das obras de infraestrutura a cargo da prefeitura, uma vez que ao loteador apenas a abertura das ruas e a marcação dos lotes ficavam afetas (BADARÓ, 1996: p.122).
\end{abstract}

Esta especulação é evidenciada por Semeghini (2006) através da análise da relação entre a área urbana e o número de habitantes: em 1940, há 197,5m² de área urbana parcelada para cada habitante; em 1968, são 349m² e em 1980, são 292m².

Foi a partir da década de 1950, portanto, que se alterou a distribuição das áreas urbanas no município de Campinas. A cidade passou a se expandir predominantemente através de parcelamentos distantes e desconectados da área urbana existente, gerando grandes vazios. A maioria destes loteamentos ocorreu no sentido sudoeste, em direção ao Aeroporto de Viracopos ${ }^{48}$, e no sentido noroeste, próximos à Rodovia Anhanguera.

Para Semeghini (2006), os principais fatores para a horizontalização do espaço urbano com produção de vazios foram: a instalação de novas indústrias - que aconteceu ao longo da Rodovia Anhanguera; e a atuação da Companhia de Habitação Popular (COHAB). De 1967 (ano de sua criação) até 1970, a COHAB é responsável por $51 \%$ do total de novas residências em Campinas, todas em conjuntos habitacionais distantes da malha urbana. "Repetiu-se com a ação da COHAB, em

48 Implantado na década de 1930, o aeroporto passa a participar efetivamente no processo de desenvolvimento do município na década de 1950, sendo utilizado comercialmente por empresas aéreas brasileiras. 
escala ampliada, a indução à especulação desenvolvida pela localização industrial" (SEMEGHINI, 2006: p.61). Porém, é importante destacar que a expansão horizontal tem início anteriormente por ações do poder público municipal, representativo de interesses da elite dominante e do setor imobiliário, e pela própria implantação do sistema rodoviário, como visto através de autores como Badaró (1996) e Fernandes (2004). Para estes autores, a ação da COHAB, na verdade, segue e reforça uma indução de crescimento já estabelecida anteriormente à data de sua criação.

De qualquer modo, a expansão especulativa repercutiu sobre o poder público sob a forma de custos e dificuldades crescentes para a demanda de serviços e equipamentos: toda a infra-estrutura, assim como as linhas de ônibus e coleta de lixo, tiveram que se estender através dos vazios urbanos para atingir os loteamentos periféricos. "A dotação de infra-estrutura em áreas vazias, obtida pela inversão de recursos públicos, possibilitando a apropriação privada do diferencial de valor de terra assim gerado, constitui uma das principais formas de ganho especulativo" (SEMEGHINI, 2006: p.61).

Na década de 1960, observa-se o mesmo movimento de expansão, com a implantação de áreas distantes cerca de $15 \mathrm{~km}$ do centro urbano, intensificando a dispersão urbana iniciada em 1950. Em 1968, a área urbana é de $110 \mathrm{~km}^{2}$, o dobro da existente em 1954, dos quais apenas $40 \%$ são efetivamente ocupados (CANO \& BRANDÃO, 2002: p.125). A contrapartida deste processo de horizontalização da periferia revelou-se na valorização das áreas com urbanização já consolidada, valorização esta que, exacerbada, condicionou e estimulou o processo de verticalização, como reciclagem do espaço urbano.

A interdependência destes dois processos - horizontalização e verticalização no caso campineiro, envolveu, de acordo com Zimmermann (1987: p.97), a participação de dois outros segmentos do capital mercantil: o transporte coletivo e o comércio varejista. Ou seja, a ocupação desordenada e de baixa densidade, implicando na operação de linhas de transporte coletivo que demandavam o centro da cidade (já que a inexistência de interligação entre os bairros tornou obrigatórias as baldeações), favoreceu a extrema concentração do comércio: primeiro, pela inexistência do comércio descentralizado devido à baixa densidade das áreas periféricas; segundo, pelo aumento do trânsito de pessoas em função da necessidade de baldeação - fatores que contribuíram para o processo de supervalorização do solo. 
Se em certo momento da história da cidade e em certo momento do pensamento urbanístico, a ocorrência do fenômeno de verticalização era tida como fator de "modernidade", e mesmo até como legítima aspiração, a partir da década de 1970, tal situação começa a ser rediscutida. Neste sentido, diagnosticando a eventual saturação frente ao desenvolvimento futuro da cidade, o Plano Preliminar de Desenvolvimento Integrado ${ }^{49}$ (PPDI) vai propor o remanejamento da área central. Descartou o crescimento do município vetorial à sudoeste e contínuo à oeste, ainda que até hoje aconteçam nestes sentidos. Definiu como áreas de expansão preferenciais as regiões norte e nordeste, que sofreram grande elevação de preços e transformou esses territórios em reservas especulativas de valor imobiliário, inibindo sua ocupação. De outro lado, as áreas periféricas à oeste e sudoeste permaneceram mal equipadas e desprovidas de infra-estrutura ao longo das décadas de 1970 e 1980, e permanecem com grandes déficits até hoje, quando as administrações foram, na prática, forçadas a investir na grande periferia.

Esta indução estabelecida pelo PPDI permitiu o agravamento de situações que já se apresentavam como inadequadas, principalmente em relação à tendência já então manifesta - no sentido de extensas áreas loteadas, ainda que, em certos casos, irregularmente - de crescimento sudoeste da cidade em direção às Rodovias Anhanguera e Bandeirantes, sob a justificativa de se evitar um setor segregado espacialmente. De fato, efeito da indução dos fluxos regionais, impulsionado pelas atuações da própria $\mathrm{COHAB}$ e apesar das diretrizes de estruturação espacial proposta em 1970, o crescimento intenso à sudoeste mostrou-se a principal direção de expansão periférica, com predominância de autoconstrução, sub-habitação e conjuntos habitacionais. Desenvolve-se assim, a segunda periferia urbana de Campinas, que se deu, sobretudo, entre 1964 e 1980, e foi marcada pelo surgimento das primeiras favelas no município, ocupando principalmente áreas públicas ou áreas de lazer dos loteamentos centrais e dos loteamentos irregulares implantados anteriormente.

Os primeiros conjuntos do BNH aproveitaram terrenos ou glebas remanescentes que pertenciam às prefeituras. Boa parte desses bens patrimoniais, adquiridos anos antes, situava-se em áreas relativamente consolidadas ou em processo de urbanização. Esgotado este estoque original, a partir da segunda metade

\footnotetext{
${ }^{49}$ O Plano Preliminar de Desenvolvimento Integrado - PPDI foi elaborado em 1970, no rol das exigências a nível federal e aborda a área central de forma genérica, sem questionar sequer os altos índices de construção permitidos.
} 
da década de 1970, a valorização generalizada das glebas urbanas para empreendimentos habitacionais, levou os novos conjuntos a serem planejados e executados em áreas distantes, sem provimento de infra-estrutura e, por vezes rurais. Essa localização distante induziu ao surgimento de loteamentos nas suas imediações, cujos lotes foram lançados, vendidos e edificados antes mesmo da entrega das unidades do conjunto habitacional vizinho. Segundo Ribeiro, ocorre uma "política clara de segregação sócio-espacial, onde os empreendimentos públicos oferecidos como soluções habitacionais para baixa-renda vão se localizar na mesma região onde a iniciativa privada já iniciava um processo de ocupação com loteamentos irregulares" (RIBEIRO, 2006: p.32).

Este processo de formação da segunda periferia de Campinas aconteceu paralelamente a outro processo - o de "interiorização" da indústria paulista. Assim como o estado de São Paulo, Campinas apresentava, na década de 1970, maiores taxas de crescimento populacional do que a média nacional. A partir desta década, Campinas apresentou taxas menores de crescimento populacional que as cidades do seu entorno, o que revela uma desconcentração industrial e populacional no município, em detrimento do processo acelerado de expansão física dos municípios de entorno, que resultou, portanto, em um processo de grande expansão urbana regional, com intensa conurbação, sendo a via Anhanguera o principal eixo condutor.

\begin{abstract}
A integração do mercado regional, a expansão da mancha urbana de todos os municípios da região, a localização das indústrias ao longo das principais rodovias (Anhanguera, Bandeirantes, Dom Pedro I, Santos Dumont, Campinas-Mogi Mirim) e nas proximidades do aeroporto de Viracopos foram fatores que impulsionaram a formação desse espaço urbano-metropolitano e contribuíram para a relativa desconcentração populacional do município-sede em relação aos municípios vizinhos (FONSECA, DAVANZO \& NEGREIROS, 2002: p.123).
\end{abstract}

Em 1999, um estudo realizado pelo IPEA, com a participação do IBGE e de outros centros de pesquisa, identificou Campinas como metrópole regional. A Região Metropolitana de Campinas (RMC), única aglomeração urbana não nucleada por uma capital de estado, foi criada oficialmente em 2000 pelo governo estadual ${ }^{50}$. O processo

50 A Região Metropolitana de Campinas é composta por 19 municípios paulistas: Americana, Artur Nogueira, Campinas, Cosmópolis, Engenheiro Coelho, Holambra, Hortolândia, Indaiatuba, Itatiba, Jaguariúna, Monte Mor, Nova Odessa, Paulínia, Pedreira, Santa Bárbara D’Oeste, Santo Antônio da Posse, Sumaré, Valinhos e Vinhedo. Conforme censo do IBGE de 2000, a RMC abrange cerca de 2,3 milhões de habitantes. 
de metropolização foi constatado a partir de dois movimentos: um físico, relacionado à expansão da malha urbana que configura uma área urbanizada interligada por Campinas - município sede ou cidade-núcleo, ainda que com presença de vazios; outro, de cunho sócio-econômico e político-administrativo, apresentando um conjunto de atividades que se alavancam mutuamente entre cidade-núcleo e cidades periféricas. No entanto, o processo de metropolização de Campinas e região se difere do processo da Região Metropolitana de São Paulo (RMSP) (FONSECA, DAVANZO \& NEGREIROS, 2002: p.29-36).

É um movimento que não repete o da formação da metrópole de São Paulo. Em outro tempo e outras circunstâncias, a metropolização em Campinas expressa uma grande mudança na forma de organização urbana do território, possibilitada pela tecnologia que permite uma produção industrial da cidade (haja vista a construção extremamente rápida do shopping Parque D. Pedro), por novas combinações entre o poder público e a iniciativa privada, dentro da tendência geral de formação de aglomerações urbanas que se manifesta em diversos pontos do território brasileiro (e em outras nações), originada por razões diferentes conforme a região (FONSECA, DAVANZO \& NEGREIROS, 2002: p.29).

Ainda segundo Fonseca, Davanzo \& Negreiros (2002: p.36), "nos anos 80 e 90 completou-se e consolidou-se a mudança de patamar da inserção de Campinas na região, no estado e no país. Isto se expressou no desenvolvimento e adensamento da aglomeração urbana, que se expandiu e rearticulou, adquirindo maior grau de complexidade". 


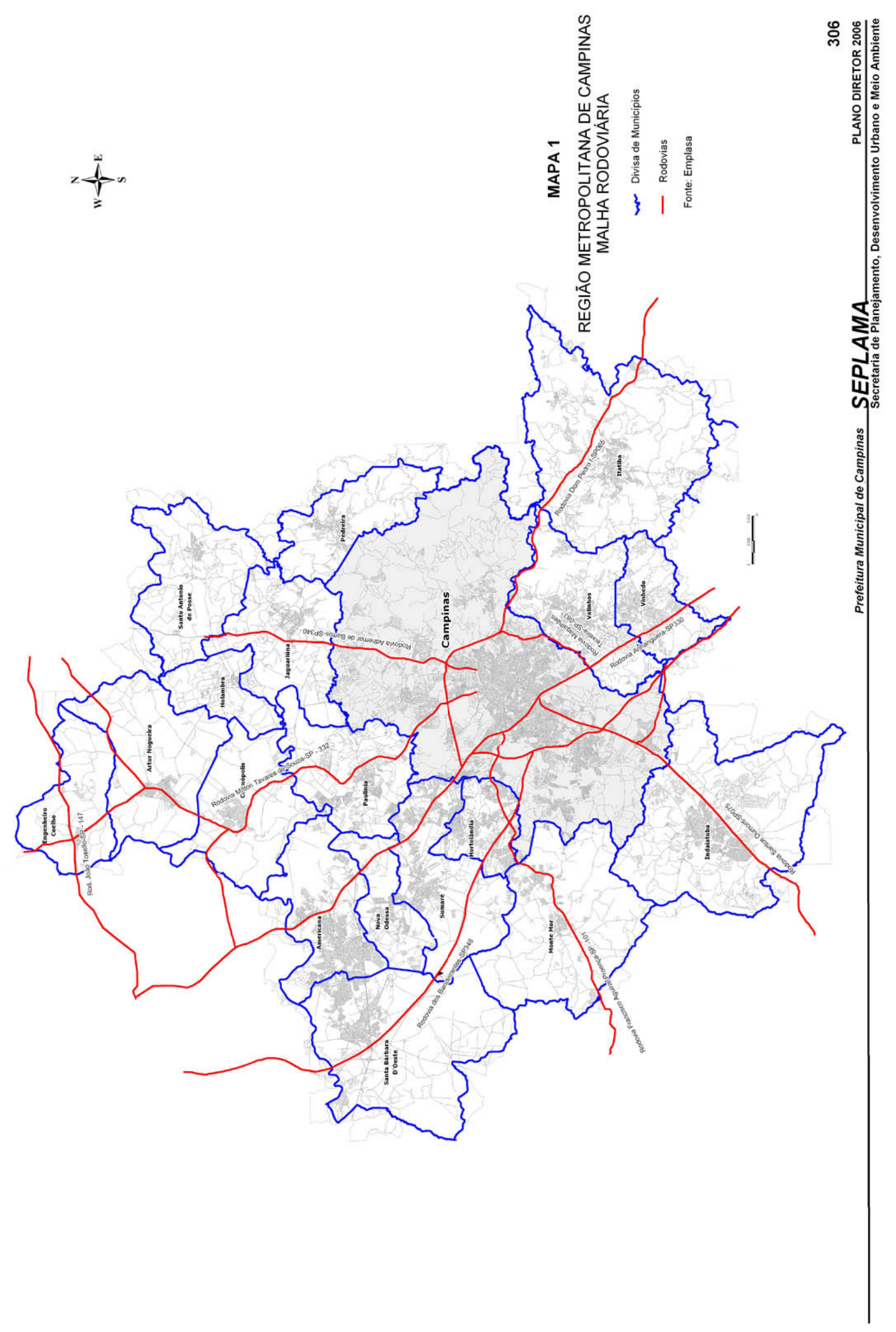

Figura 12 - Malha Rodoviária da Região Metropolitana de Campinas (RMC)

Fonte: Plano Diretor de Campinas 2006 (Disponível em:

http://www.campinas.sp.gov.br/seplan/publicacoes/planodiretor2006/pd2006mapas.htm) 


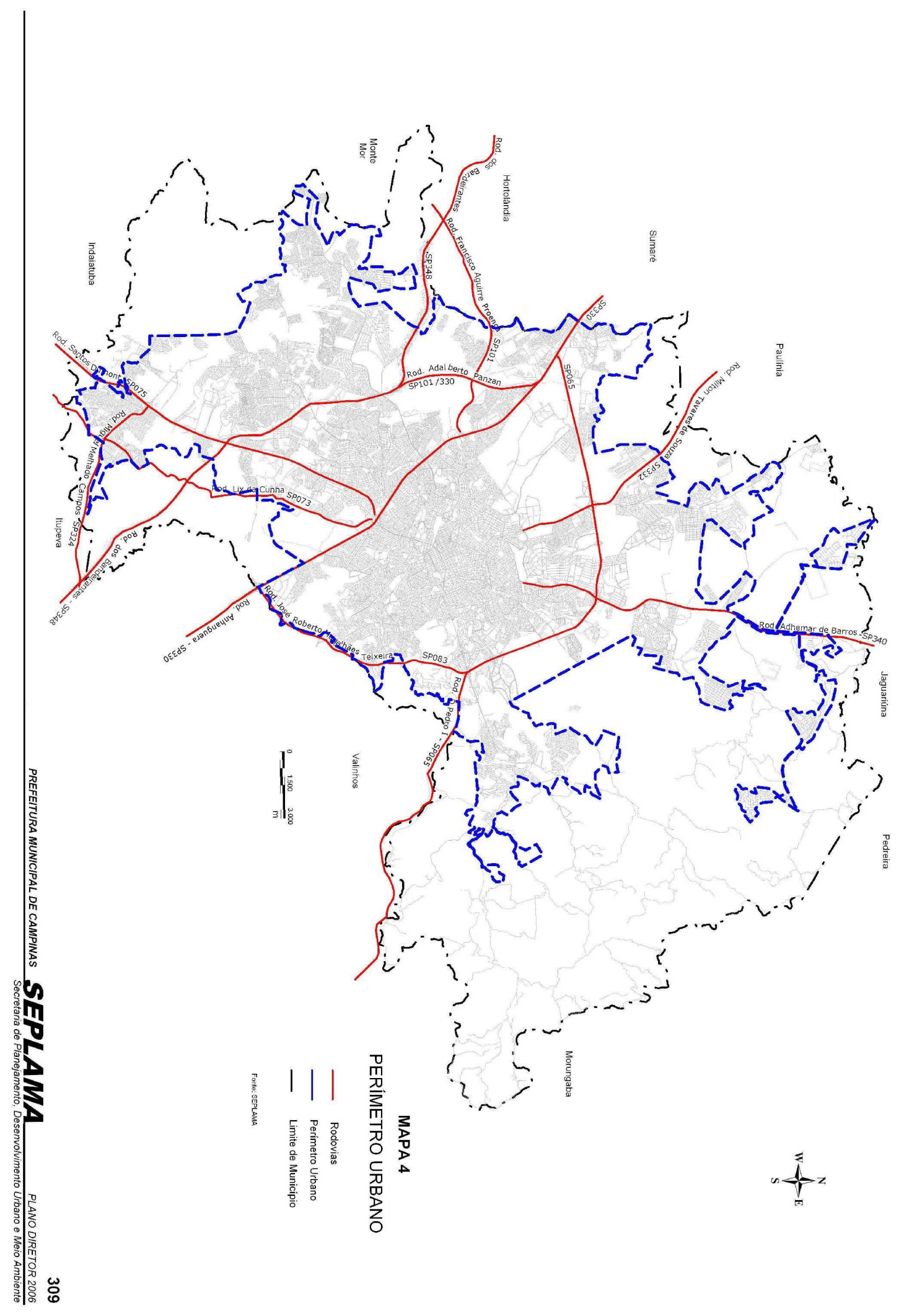

Figura 13 - Perímetro Urbano de Campinas

Fonte: Plano Diretor de Campinas 2006 (Disponível em:

http://www.campinas.sp.gov.br/seplan/publicacoes/planodiretor2006/pd2006mapas.htm) 


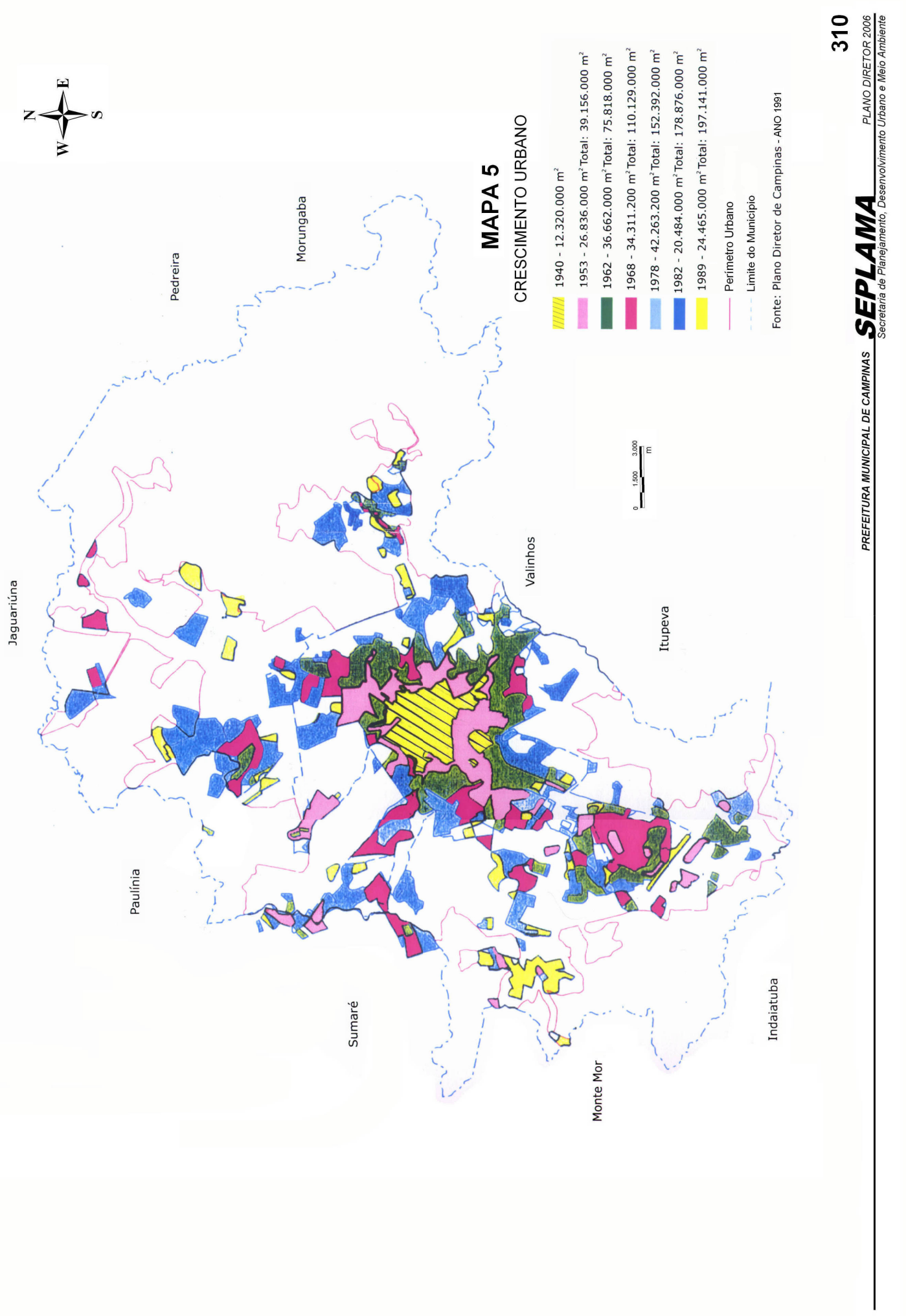

Figura 14 - Crescimento Urbano de Campinas (RMC)

Fonte: Plano Diretor de Campinas 2006 (Disponível em:

http://www.campinas.sp.gov.br/seplan/publicacoes/planodiretor2006/pd2006mapas.htm) 
Voltando para os aspectos intra-urbanos é importante destacar que a expansão urbana no município se deu, sobretudo, com a ocupação dos vazios remanescentes dos parcelamentos anteriores, resultante do processo de conformação do solo urbano que ocorreu em Campinas principalmente a partir da década de 1950. Na década de 1970, assim como no período anterior, o sudoeste continuou sendo o vetor mais intenso de expansão, marcado por um padrão de urbanização caracterizado pela precariedade de infra-estrutura das áreas ocupadas (SEMEGHINI, 2006: p. 65-68).

Nesse período, a forma de ocupação por loteamentos fechados foi introduzida nas áreas rurais, através da Lei 7.368 - "Loteamentos Rurais Fechados" -, que vigorou entre 1974 e 1980, e aprovou alguns loteamentos indicando outros vetores de expansão urbana voltados, desta vez, para a classe de renda média alta e alta. São as áreas de Gramado, à leste, e Barão Geraldo, à norte. Também foram aprovados alguns condomínios horizontais fechados, sendo o primeiro na área do Taquaral, através da Lei Federal nำ 4.591/64, que regulamentou, a princípio, condomínios verticais. Somente a partir de 1988, o município de Campinas apresenta legislação específica para condomínios horizontais fechados ${ }^{51}$.

Esses empreendimentos, aprovados na década de 1970, indicam o início de um novo processo de ocupação que foi intensificado nas décadas seguintes. Ao longo da década de 1980, foram implantados diversos loteamentos ao norte (Barão Geraldo e Taquaral) e ao leste (Sousas), em áreas distantes do tecido urbano constituído anteriormente, mas próximos às rodovias, seguindo a lógica regional de localização. $A$ cidade se expandiu principalmente nas imediações da Rodovia D. Pedro I, nos sentidos norte, noroeste e leste, e além da Rodovia Bandeirantes, a oeste. Ao sul, ocorreram apenas alguns loteamentos ${ }^{52}$. À leste, em direção aos distritos de Sousas e Joaquim Egídio, houve a implantação de grandes áreas institucionais, áreas agrícolas e zonas de preservação ambiental.

\footnotetext{
${ }^{51}$ Para estudo sobre Loteamentos e Condomínios fechados em Campinas, ver: SILVA, Paula Francisca Ferreira. A Expansão Urbana de Campinas através de Condomínios e Loteamentos Fechados (19742005). São Carlos, Departamento de Arquitetura e Urbanismo, Escola de engenharia de São Carlos, USP (Dissertação de Mestrado), 2008.

52 Segundo Semeghini, (2006: p.65-66), os principais condicionantes de ocupação dos eixos norte e nordeste são a inauguração da Rodovia D. Pedro I, a implantação da UNICAMP, da PUCC, da empresa REPLAN e da Companhia de Desenvolvimento do Pólo de Alta Tecnologia de Campinas (CIATEC)
} 


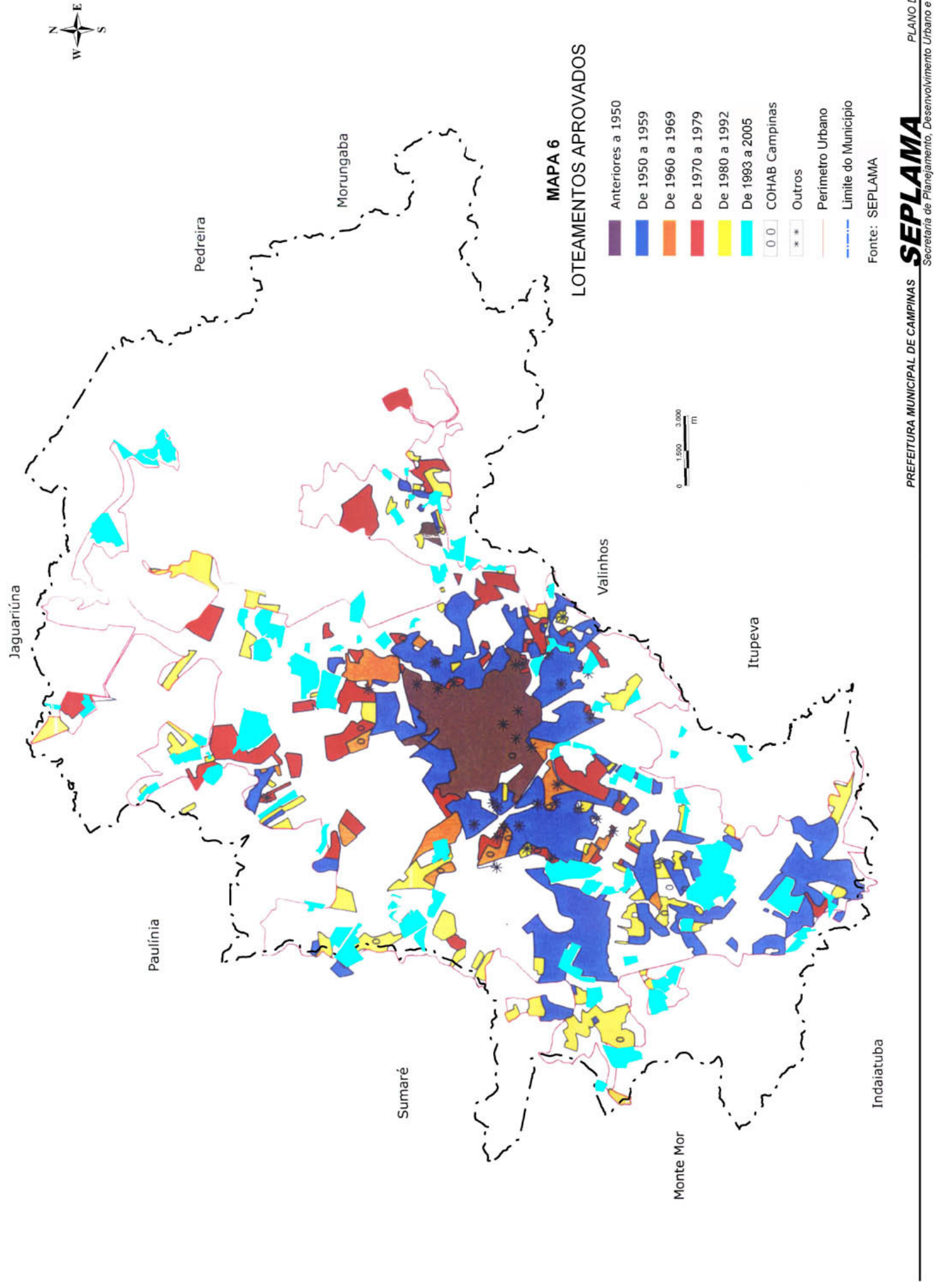

Figura 15 - Loteamentos aprovados de Campinas

Fonte: Plano Diretor de Campinas 2006 (Disponível em:

http://www.campinas.sp.gov.br/seplan/publicacoes/planodiretor2006/pd2006mapas.htm) 


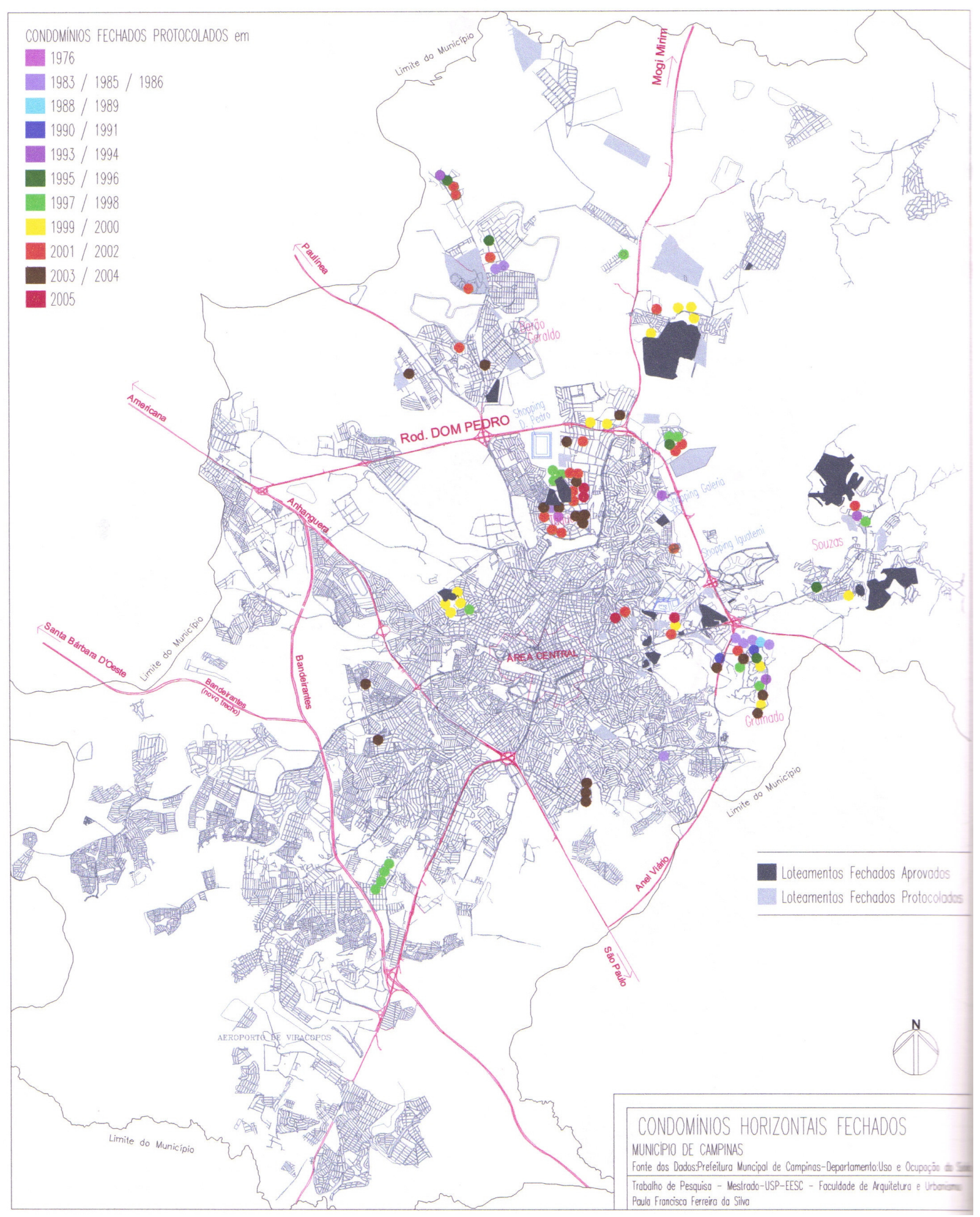

Figura 16 - Condomínios Horizontais Fechados no município de Campinas (1976-2005). (Fonte: SILVA, Paula Francisca Ferreira, 2008) 


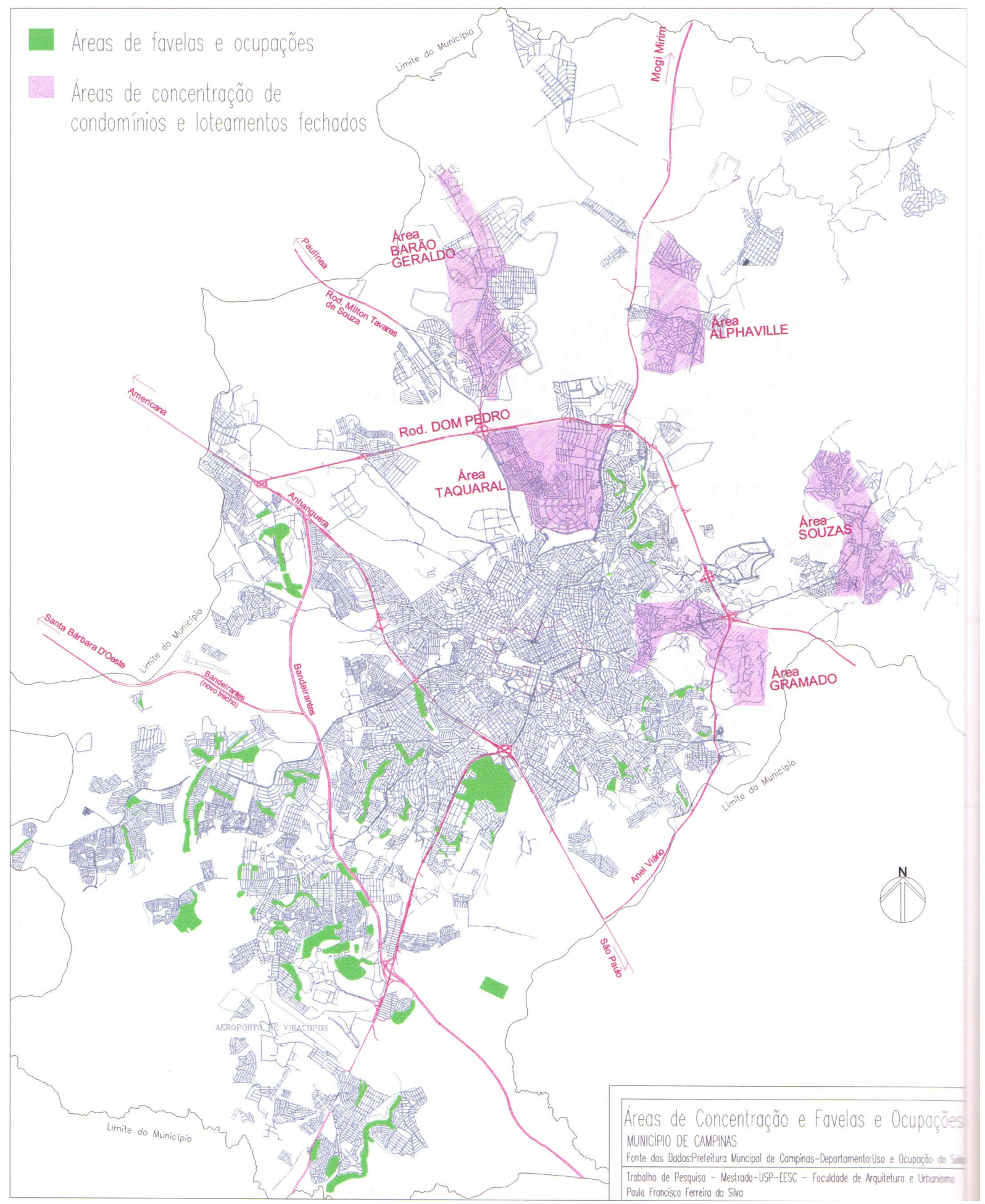

Figura 17 - Favelas, Ocupações Irregulares e Áreas de Concentração de Condomínios e Loteamentos Fechados em Campinas na década de 2000.

(Fonte: SILVA, Paula Francisca Ferreira, 2008) 
Conforme a análise de Semeghini (2006: p.60-61), na década de 1980, metade da área urbanizada de Campinas constituía-se de vazios. A expansão especulativa, associada à lógica regional de implantação em imediações de eixos rodoviários, reflete-se sobre o poder público, gerando custos e dificuldades crescentes para a implantação de infra-estrutura em áreas distantes. Ainda assim,

a partir de meados da década de (19)80, inicia-se nova fase de expansão urbana e de valorização imobiliária, mais voltada ao atendimento das classes média alta e alta, que são os chamados loteamentos fechados e condomínios, os quais foram se instalando nas regiões norte e leste, em áreas de terras mais valorizadas (CANO BRANDÃO, 2002: p.126).

Houve ainda a implantação de grandes centros de consumo regionais, como hipermercados e shopping centers, além das ditas "novas centralidades" onde se concentraram centros tecnológicos e empresariais (SEMEGHINI, 2006: p.65). Esses fatores inserem Campinas no debate acerca da tendência observada nas áreas centrais de algumas cidades brasileiras metropolitanas, onde o caráter fortemente popular que adquire o centro da cidade - frente à movimentação da classe de renda média alta e alta -, conhecido como processo de "decadência" dos centros, é sugerido, principalmente, pela transferência de usos e desvalorização imobiliária.

Diante da ineficácia da política pública em atender a demanda por moradia, tanto em termos quantitativos, como no sentido de assegurar a aquisição do imóvel ${ }^{53}$, reforça-se a busca por alternativas de moradia, ainda que precárias, sendo representativo o promissor mercado de aluguel irregular. Além disso, como se sabe, a política habitacional desenvolvida a partir do Banco Nacional de Habitação (BNH) baseou-se na construção de grandes e distantes conjuntos periféricos, como tem sido corrente nas ações da COHAB e da CDHU. O objetivo de reduzir os custos de obtenção de terrenos determinou enormes despesas com a implantação de infraestruturas e equipamentos. Do ponto de vista urbano, esses conjuntos contribuíram para agravar problemas ambientais e favoreceram a expansão exagerada da ocupação, estimulando a formação de vazios urbanos e a especulação com terrenos rurais e periféricos. Apesar disso, não significam custos finais necessariamente mais baixos do que se poderiam obter em localizações mais centrais.

${ }^{53}$ Conforme Fernandes (2004: p.102-120), são inúmeros os casos de inadimplência que acabam em despejo e recomercialização da unidade ou ainda, em transferência irregular do imóvel a terceiros com o chamado "contrato de gaveta". 
A obtenção ilegal de moradia, neste sentido, é umas das poucas alternativas encontradas pela população de classe de renda baixa, perante os problemas habitacionais brasileiros, causados principalmente pela violenta especulação imobiliária, que organiza o espaço urbano de acordo com o interesse do capital. A incapacidade quantitativa e qualitativa da política habitacional em atender a essa faixa de demanda por moradia, justifica a reversão da idéia dominante de transitoriedade e de erradicação, para uma política de fixação e urbanização no próprio local.

Se isso deixava as elites menos aflitas na segunda metade da década de 1980, em contrapartida, criava uma situação de conseqüências preocupantes na questão da moradia. Sem acesso à aquisição de unidades dos conjuntos habitacionais em função dos preços e das exigências contratuais do SFH, sem oferta de lotes populares baratos pela iniciativa privada - pois os loteamentos irregulares estavam na mira da Lei Lehmann ${ }^{54}$-, sem recursos e condições legais de se tornarem locatárias, e sem a disponibilidade de novos barracos nas favelas, as famílias de baixa renda vão buscar a solução do seu problema de moradia de outras formas, como através das ocupações organizadas de glebas particulares ou loteamentos irregulares - "constituindo uma sobreposição de ilegalidades" (FERNANDES, 2004: p.108) e dos aluguéis informais na "decadente" área central da cidade.

Observa-se atualmente, então, outras modalidades de habitação popular no município de Campinas, seguindo novas lógicas de movimentação e distribuição da pobreza, que se processam em grandes cidades metropolitanas. À medida que o território se expande, o pobre busca encontrar outras formas relacionais com o espaço urbano. É diante deste cenário que ganha ênfase a presença de cortiços na área central - ora como cortiços de fato, ora como hotéis e pensões populares, como veremos a seguir - enquanto tentativa de uso desta porção do território tão marcada por interesses, sobretudo, do mercado imobiliário.

\footnotetext{
${ }^{54}$ Lei Federal n 6.766/79, que regulamenta o parcelamento do solo urbano em todo o país, e dispõe sobre fiscalizações e medidas punitivas.
} 


\subsection{Reconhecendo o cortiço em áreas centrais enquanto modalidade de habitação popular atual}

Através de pesquisa documental e exploratória, é possível demonstrar que existem - ainda que pesem as imprecisões devido à falta de consenso quanto à determinação da habitação coletiva popular em áreas centrais ${ }^{55}$ - pessoas vivendo precariamente na área central de Campinas, apesar do foco do déficit habitacional concentrar-se nas áreas periféricas. Os inúmeros hotéis e pensões populares existentes, onde se observa pessoas vivendo de modo precário e em condições muito próximas àquelas que determinam os atuais cortiços, não são assim classificados, tornando a estimativa equivocada. $\mathrm{O}$ mesmo se dá em relação à quantificação da população residente em tais condições cuja maioria é classificada como "transitória" e não aparece em dados censitários, ainda que "transitem" pelos mesmos tipos de moradia na área central. Em contraposição à idéia de esvaziamento da área central ${ }^{56}$, observa-se a apropriação dos imóveis desocupados e degradados por parte da população pobre, como noticiado nos principais jornais televisivos e impressos da cidade $^{57}$.

O perímetro adotado para estudo (Fig. 17) baseou-se na primeira planta cadastral de Campinas, levantada em 1929, na gestão do então prefeito Orosimbo Maia, e contempla significativa parte dos bens tombados ou em estudo de tombamento pelo Condepacc, incluindo a poligonal estabelecida como Centro Histórico pelo Decreto ํo. 10.424 de 06 de maio de 1991. O primeiro recorte espacial adotado para a pesquisa compreende o perímetro delimitado pela Avenida Aquidaban, Rua Irmã Serafina, Avenida Anchieta, Rua Guilherme da Silva, Avenida Julio de Mesquita, Rua Olavo Bilac, Rua Carlos Guimarães, Avenida Orosimbo Maia, Rua Jorge Krug, Avenida Barão de Itapura, Rua Dr. Ricardo, Rua Lidgerwood e Avenida dos Expedicionários. Quatro subáreas compõem este perímetro, divisão adotada

\footnotetext{
${ }^{55}$ Segundo Piccini (1999), a quantificação deste tipo precário de habitação é problemática, seja pela falta de pesquisas sistemáticas ou pela conceituação dessa modalidade de moradia. As pesquisas e os censos não são suficientes para determinar os períodos de redução e de crescimento da população dos cortiços nas áreas centrais e mesmo no conjunto da cidade.

${ }^{56}$ Os dados demonstram que "ao longo dos últimos 30 anos houve um aumento da desocupação de imóveis em bairros mais centrais e bem mais aparelhados de infra-estrutura" (MORETTI e JANUZZI, 2002: p.285), apresentando uma crescente deterioração física das construções, apesar da demanda de uso, comprovada pelo forte mercado rentista atuante na área. Reforçando tal idéia de tendência de esvaziamento, um estudo sobre a Estruturação Territorial do município, integrante do processo de revisão do Plano Diretor, em 2004, apontou um decréscimo de população da Área Central da ordem de 10,17\%, entre 1991 e 2000, com taxas anuais negativas de 1,13\% em média.

57 Série de reportagens televisivas EPTV Campinas, janeiro de 2008.
} 
também para os "Estudos de Inventário da Região Central de Campinas", finalizado em 2008, através da Coordenadoria Setorial do Patrimônio Cultural (CSPC), setor ligado à Secretaria da Cultura de Campinas. Para a presente pesquisa foram acrescidas outras duas subáreas: porção da Vila Industrial, localizada além da Estação Ferroviária Paulista, e porção localizada além da Estação Ferroviária Mogiana, conforme o mapa a seguir (Fig. 17). A adoção do mesmo perímetro utilizado pela CSPC justifica-se por delimitar área homogênea com grande concentração de prédios antigos de interesse histórico-arquitetônico, alvo de intervenções urbanas na área $^{58}$. As duas áreas acrescidas justificam-se pela tentativa de avaliar a existência de habitação coletiva popular, que se apresentam ora como cortiços, ora como hotéis e pensões, na área situada além da linha férrea ${ }^{59}$. Destaca-se, neste sentido, o parque ferroviário enquanto barreira de difícil transposição, que desde sua implantação separa o Centro e a região Sudoeste do município - "lugar de cortiço, oficinas, matadouro, curtumes, lazaretos, vilas operárias, indústrias" (BITTENCOURT, 2000: p.134) - como sendo a contenção de uma apropriação mais massiva do Centro, por parte da classe de renda mais baixa, que já a utiliza enquanto local de trabalho, compras e acesso à equipamentos públicos educacionais e de saúde.

${ }^{58}$ Embora vários nomes sejam dados às intervenções urbanas em áreas centrais, é possível aglutinar esses processos sob duas definições: renovação e reabilitação urbanas. Maricato (2001, p. 126) evidencia que, a renovação urbana tem como objetivo a substituição de "edificações envelhecidas, desvalorizadas, que apresentam problemas de manutenção, por edifícios novos e maiores" com demolição, aglutinação de terrenos contíguos e aumento da ocupação do solo. Já a reabilitação urbana é marcada pelo esforço em manter o tecido urbano o mais inalterado possível, com ímpeto por preservar a estrutura fundiária, o parcelamento do solo, as edificações pré-existentes, os usos e a população da área. A reforma necessária na infra-estrutura existente para adaptá-la a novas necessidades procura não descaracterizar o ambiente construído herdado e busca fazer "intervenções mínimas" nos edifícios, indispensáveis para garantir conforto ambiental, acessibilidade e segurança estrutural.

${ }^{59}$ A Vila Paulista, juntamente com outros bairros localizados no vetor sudoeste do município, apresentava em 2000, o maior número de responsáveis por domicílio com renda de até meio salário mínimo (Censo IBGE/PNAD 2000. 


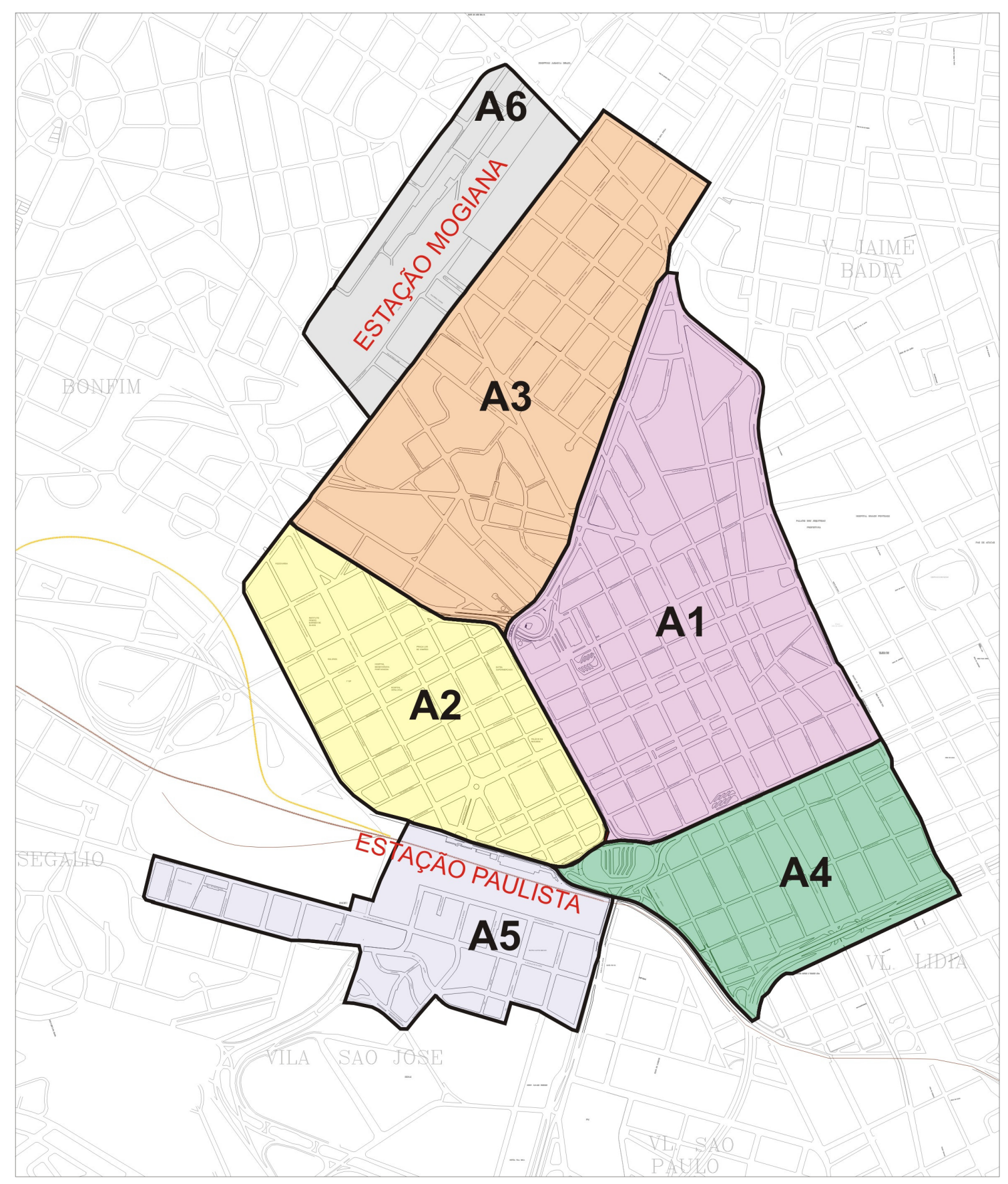

Figura 18 - Perímetro de Estudo e suas respectivas áreas Fonte: Arquivo pessoal

A área denominada Área $1^{60}$ caracteriza-se pela presença predominante de comércio de grande porte, com instalação de grandes redes de lojas junto às vias de fluxo intenso de veículos automotores e pedestres. É uma área muito bem atendida

${ }^{60}$ Delimitada pela Rua Orozimbo Maia (à noroeste), Avenida Anchieta (à leste), Avenida Dr. Moraes Sales (ao sul), Avenida Senador Saraiva (à oeste). 
pelos serviços públicos, principalmente no que se refere ao transporte coletivo. A área ainda apresenta comércio de pequeno e médio porte concentrados nas vias de menor fluxo, que, em geral, funcionam em antigos edifícios de dois pavimentos. Nestes, o segundo pavimento, que até pouco tempo funcionava como moradia, atualmente destina-se ao estoque das próprias lojas, à locação de salas, ou está abandonado. Assim, entende-se esta área como sendo a mais dinâmica e de caráter mais voltado ao comércio e aos serviços, onde notadamente encontram-se, inclusive, as oportunidades de empregos que a população de baixa renda busca.

O processo de verticalização já é bastante consolidado nesta área. Diversos edifícios altos estão sendo construídos, em geral, para uso empresarial. Os edifícios mais antigos ainda conservam seu uso residencial, embora já existam alguns inteiramente vazios. As quadras mais próximas da Avenida Senador Saraiva, do "camelódromo" e terminal de ônibus urbano, são caracterizadas como zona de transição das áreas envoltórias para esta porção mais dinâmica do centro da cidade em termos de tipologia e gabarito de edifícios, uso e ocupação do solo, intensidade de fluxos de pessoas e veículos automotores. Entre eles, destaca-se o grande fluxo dos veículos utilizados no sistema público de transporte coletivo, que é feito por ônibus e vans, sendo esta a área mais bem atendida por este serviço.

As ruas mais largas, de traçado ortogonal, são asfaltadas e apresentam fluxo intenso de pessoas e veículos automotores. Há ainda algumas vias mais estreitas, onde se mantém o paralelepípedo, de baixo fluxo de veículos, sendo nelas predominante o fluxo de pedestres. Nestes locais, de menor movimentação, encontramos focos de habitações coletivas precárias. A área ainda concentra boa parte dos mais importantes edifícios tombados como patrimônio histórico da cidade.

Seguindo a tendência de áreas centrais metropolitanas, boa parte dos edifícios da área encontram-se vazios, com alto grau de degradação e sendo sistematicamente invadidos por moradores sem teto, recém-chegados de outros estados principalmente da região nordeste do país - ou vindos de bairros periféricos, distantes de seus locais de trabalho. Outro fato bastante característico são as constantes demolições de edifícios antigos - alguns de interesse histórico-arquitetônico -, para dar lugar a inúmeros estacionamentos e edifícios comerciais e empresariais.

No entorno desta porção mais dinâmica do centro encontram-se áreas com predominância de edifícios residenciais, de fluxo menos intenso de veículos automotores, com bolsões de comércio e prestação de serviços especializado, com 
menor grau de verticalização, e que se interconectam diretamente à Área 1, pelas possibilidades que a mesma oferece. São áreas que trazem algumas especificidades, importantes de serem destacadas para melhor entendimento do perímetro de estudo.

A subárea denominada Área $2^{61}$ (Fig. 28), tem como principais eixos viários a Avenida Andrade Neves, Rua Onze de Agosto e Avenida Senador Saraiva no sentido noroeste-sudeste, e Rua Benjamim Constant e Avenida Dr. Campos Sales no sentido sudoeste-nordeste, com grande fluxo de veículos e tráfego de transporte público coletivo. Apresenta ainda o "Calçadão 13 de Maio" com comércio e serviços formais e informais voltados para classe de renda média-baixa e baixa. A tipologia predominante é de edifícios de até dois pavimentos, em geral com comércio e prestação de serviços no térreo e habitações no pavimento superior.

Esta área pode ser dividida em três partes distintas, a partir de algumas características observadas. A linha divisória é a Avenida Andrade Neves. De um lado tem-se comércio e serviços para atendimento local, onde se concentra a população moradora da área. A movimentação é menos intensa e predominantemente feita por pedestres. Nos últimos meses tem-se observado mudanças em alguns aspectos da área - como estado de conservação de fachadas e pavimentação de passeio público que passou a ser caminho para o novo Terminal Rodoviário, inaugurado em 2008. Do outro lado da avenida, observamos a predominância do uso comercial e de serviços do tipo especializado, com a presença de dois grandes bolsões especializados saúde e automotivos -, e um fluxo considerável de veículos. A partir do calçadão, em direção ao "camelódromo" localizado abaixo do Viaduto M.V. Cury, encontramos uma concentração de prostíbulos e "casas de show". Há muito fluxo de pessoas, já que a área é local de passagem e acesso ao "camelódromo", além dos próprios moradores e freqüentadores da área.

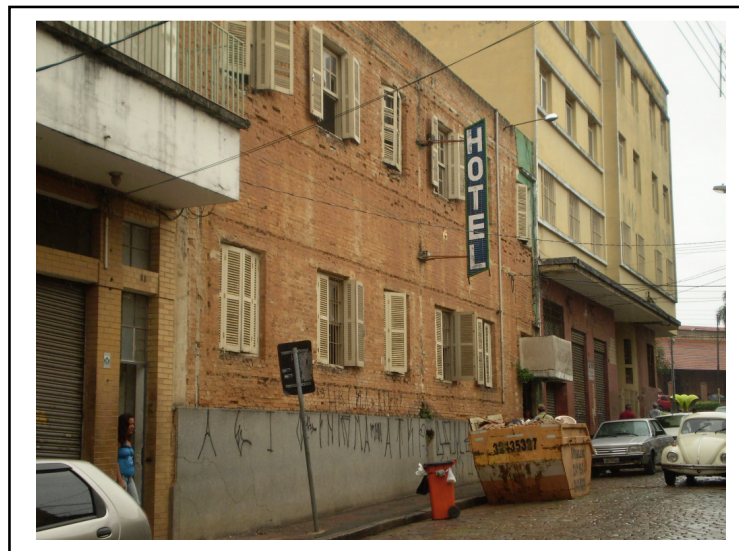

Figura 19 - Hotel popular com presença de atividades ligadas à prostituição Rua Ferreira Penteado, nำ 80 Arquivo pessoal - 22 de janeiro de 2008.

61 Delimitada pela Avenida Barão de Itapura e Rua Saldanha Marinho (ao norte), Avenida Senador Saraiva (à leste), Estação Ferroviária Paulista (à sul) e Rua Dr. Ricardo (à oeste). 
É uma área que, apesar da proximidade com a porção mais dinâmica do centro da cidade, ainda conserva características de uma área predominantemente residencial, pelas características das edificações e da maior parte das ruas, a não ser pelos corredores viários que ligam a área às outras regiões da cidade.

O comércio de locação de cômodos e vagas apresenta-se em sua maior parte em edifícios do tipo pensão e hotéis populares. A identificação de tais usos é feita por meio de anúncios junto à fachada, através de letreiros ou placas mais simples. Há ainda aqueles edifícios que não se identificam como tais, embora seja de conhecimento da população local que ofertem vagas ou cômodos. A área apresentou, segundo pesquisa de campo realizada "in loco", 83 habitações coletivas - dentre as quais se classificam os cortiços, pensões e hotéis populares informais e edifícios invadidos $^{62}$-, 40 edifícios degradados e/ou vazios, 36 hotéis aparentemente "mais formalizados $^{63 "}$ e 57 estacionamentos particulares (cf. Fig. 28).

A subárea denominada Área $3^{64}$ (Fig. 29) tem como principais eixos viários a Avenida Barão de Itapura, onde se concentram agências bancárias e serviços ligados à saúde; a Rua José Paulino, que corta a área no sentido noroeste-sudeste; e a Rua Dr. Delfino Cintra que corta a área no sentido leste-oeste. As duas últimas acabam por configurar três áreas bastantes distintas.

A primeira, que fica entre a Rua Saldanha Marinho e a Rua Dr. Delfino Cintra, apresenta maior grau de degradação, população de mais baixa renda, com alguns focos de habitações coletivas precárias e imóveis vazios e/ou degradados, principalmente junto às passagens existentes, destinadas à pedestres, que ligam a área à porção mais dinâmica do centro da cidade, na altura do Mercado Municipal. Apresenta

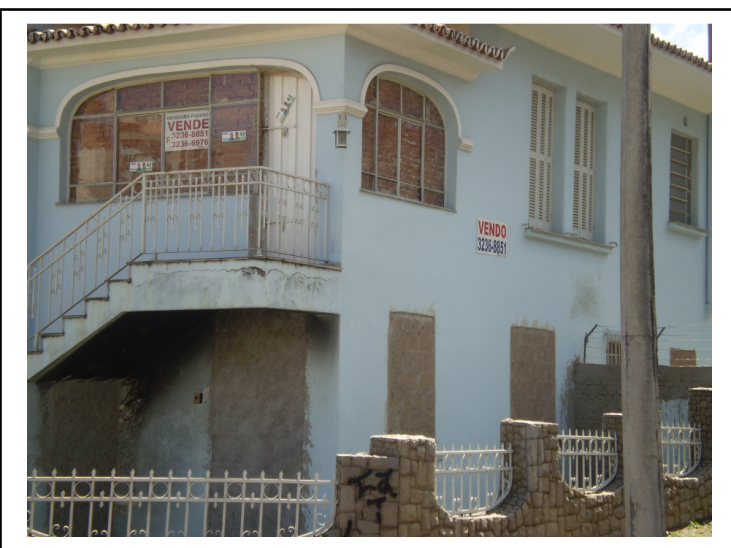

Figura 20 - Edifício à venda, com destaque as aberturas vedadas

Rua Barata Ribeiro x Rua Barão de Atibaia Arquivo pessoal - 24 de setembro de 2008 . alguns edifícios altos de uso residencial, principalmente junto à Rua Culto à Ciência, porém é predominantemente ocupada por casas de até dois pavimentos, igualmente

\footnotetext{
${ }^{62}$ As diferentes configurações de habitações coletivas precárias serão caracterizadas no Capítulo 3.

${ }^{63}$ Que apresentam anúncios indicativos de uso junto à fachada, através de letreiros, inclusive do tipo luminoso.

${ }^{64}$ Delimitada pela Rua Jorge Krug (ao norte), Avenida Orozimbo Maia (à leste), Rua Saldanha Marinho (à sul) e Avenida Barão de Itapura (à oeste).
} 
de uso residencial. A segunda área situada entre a Rua Dr. Delfino Cintra e a Rua José Paulino, é bastante verticalizada e também predominantemente residencial. Volta-se para a classe de renda média e média-alta, com grande fluxo de automóveis. Nesta área localiza-se um dos edifícios altos e inacabados invadidos há mais de 10 anos por população de baixa renda que será tratado no Capítulo 3. A terceira área, compreendida entre a Rua José Paulino e a Rua Jorge Krug, é caracterizada pela presença de agências bancárias e serviços ligados à saúde, além de restaurantes, comércio e serviços de médio e alto padrão, pela predominância de edifícios de até dois pavimentos de uso residencial, com destaque para os outros dois outros edifícios altos inacabados também invadidos, identificados pela pesquisa. Nesta área também nota-se a presença em número relevante de imóveis disponíveis para locação deflagrando o abandono da área por parte da classe de renda média-alta e alta. A área apresentou, segundo pesquisa de campo realizada "in loco", 19 habitações coletivas, 17 edifícios degradados e/ou vazios, 3 hotéis aparentemente "mais formalizados" e 41 estacionamentos particulares (cf. Fig. 29).

A área denominada Área $4^{65}$ (Fig. 30), apresenta ruas dispostas no sentido norte-sul que se configuram eixos de ligação com a porção mais dinâmica do centro da cidade. A conexão com a Área 2 se dá pelo "camelódromo" implantado junto ao Viaduto M.V. Cury, por baixo de suas alças viárias, numa espécie de labirinto que abriga moradores de rua, o tráfico de drogas, o mau cheiro, apesar da organização imposta pelo projeto para as barracas de venda de produtos. Nota-se também 0 grande número de estacionamentos particulares.

A Avenida Aquibadan configurase via de difícil transposição bastante larga e de fluxo intenso. Em um de seus lados encontra-se um "paredão" de grandes edifícios com concentração de

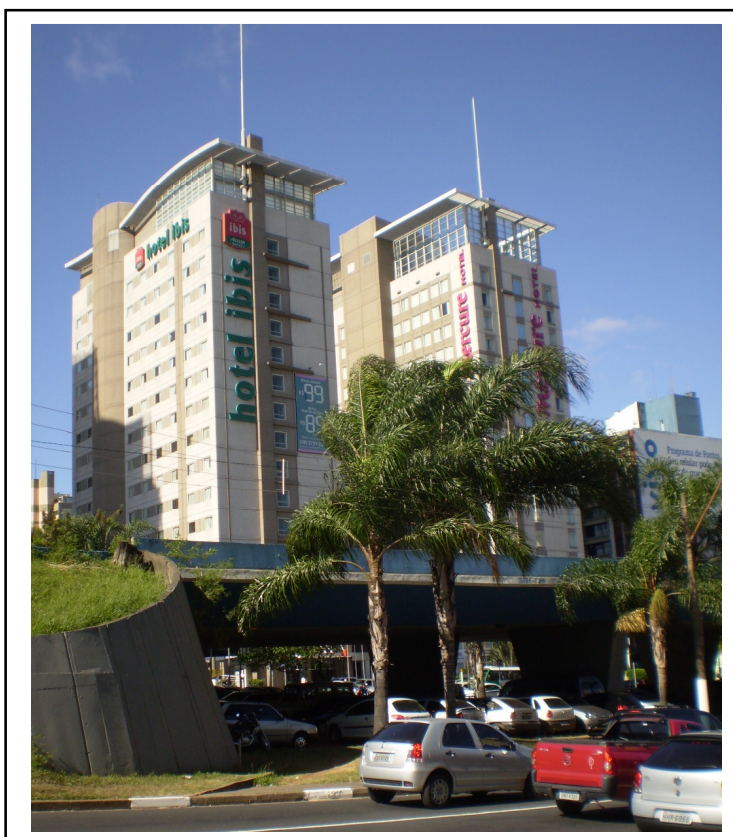

Figura 21 - Concentração de redes hoteleiras Av. Aquibadan Arquivo pessoal - 24 de setembro de 2008. redes hoteleiras de grande porte. A Avenida Senador Saraiva se configura "costas" ou

${ }^{65}$ Delimitada pela Avenida Moraes Salles (ao norte), Rua Irmã Serafina (à leste), Avenida Aquibadan (à sul) e Avenida Senador Saraiva (à oeste). 
"fundos" da área, com pouco movimento de pedestres ou tráfego local, e fluxo intenso e rápido de veículos devido ao acesso ao viaduto. Ali se encontram casas muito degradadas habitadas coletivamente, intercaladas por terrenos ocupados pelos próprios moradores como "garagem" de carrinhos utilizados para recolhimento de material reciclável. O mau cheiro é notável junto a estas áreas de depósito de lixo, assim como a presença de animais. Este ponto se configura foco de habitações coletivas precárias. A topografia apresenta certas irregularidades, sendo a Rua Barão de Jaraguá um ponto mais baixo, com as ruas perpendiculares subindo a partir dela em direção à Rua Irmã Serafina.

Nesta área de estudo não observamos placas ou outras formas de anúncio que apresentem tais edificações como pensões ou hotéis populares. Foi necessário um tempo maior de observação de fluxo de pessoas entrando e saindo de tais lugares, além de uma aproximação e contato com alguns moradores, que aí sim, apontaram para a existência de comércio de locação de "vagas" ou leitos.

A região próxima ao camelódromo tem comércio voltado às classes populares. Apresenta grande fluxo e movimento de pedestres, muito barulho, anunciantes em alto-falantes e concentração de edifícios degradados e vazios. O centro da área se caracteriza pelo comércio especializado de lojas e serviços voltados para noivas e festas de casamento em geral, mas ainda num padrão popular, sendo a Rua José Paulino a mais característica. Isso se dá até a Avenida Francisco Glicério - via mais larga, asfaltada, de tráfego intenso e bastante verticalizada. A partir desta avenida, nota-se outro padrão tanto no comércio como nos demais usos. O ponto alto se dá junto à Rua Irmã Serafina, com a Casa de Saúde Campinas, edifício muito imponente, de grande valor arquitetônico, patrimônio histórico tombado. Junto a este, encontramse outras edificações de menor porte, mas de igual valor arquitetônico, utilizados por clínicas e demais serviços de apoio. Já começa a se notar no local a demolição destes conjuntos de casas de valor histórico e arquitetônico para a construção de modernos edifícios comerciais.

O ponto de conexão desta área com a região vizinha - que não é contemplada pelo perímetro de estudo - é o Largo de São Benedito, grande praça arborizada, que atende também à creche Bento Quirino e à EEPG Francisco Glicério, dois equipamentos educacionais que funcionam em edifícios também tombados como patrimônios históricos. Do outro lado da praça observam-se grandes edifícios residenciais. Aliás, a verticalização é um ponto bastante notável, principalmente junto 
às vias de maior circulação e junto às duas praças - Largo do São Benedito e Largo do Pará. O uso em geral se dá com comércio instalado no pavimento térreo (pequenas lojas) e as unidades habitacionais nos pavimentos superiores. Isso ocorre tanto nos edifícios de 2 a 4 pavimentos, como nos mais altos, de 15 a 20 pavimentos. Observamos que tais edifícios residenciais foram construídos nas décadas de 1960 e 1970, sendo constituídos por pilotis, grandes esquadrias envidraçadas, estrutura marcante e revestimentos tais como a pastilha. Nos prédios mais novos observamos o acréscimo da garagem em dois ou três pavimentos.

A área apresentou, segundo pesquisa de campo realizada "in loco", 24 habitações coletivas, 36 edifícios degradados e/ou vazios, 3 hotéis aparentemente mais formalizados e 96 estacionamentos particulares (cf. Fig. 30).

Quatro edificações localizadas na Rua Irmã Serafina, entre a Rua General Marcondes Salgado e Avenida Aquibadan, deflagraram outro foco de habitações coletivas precárias. Neste, a partir de questionamentos junto aos moradores, encontramos Dona Rosa, administradora das quatro "pensões" e também moradora de uma delas, que apontou como proprietária dos imóveis uma advogada, que inclusive mora em um dos prédios residenciais de médio-alto padrão junto ao Largo do São Benedito, há duas quadras dali. Nesta área de estudo localizam-se duas creches: a Creche Bento Quirino, já mencionada, e a Casa Pão dos Pobres, que atendem famílias moradoras dos cortiços,

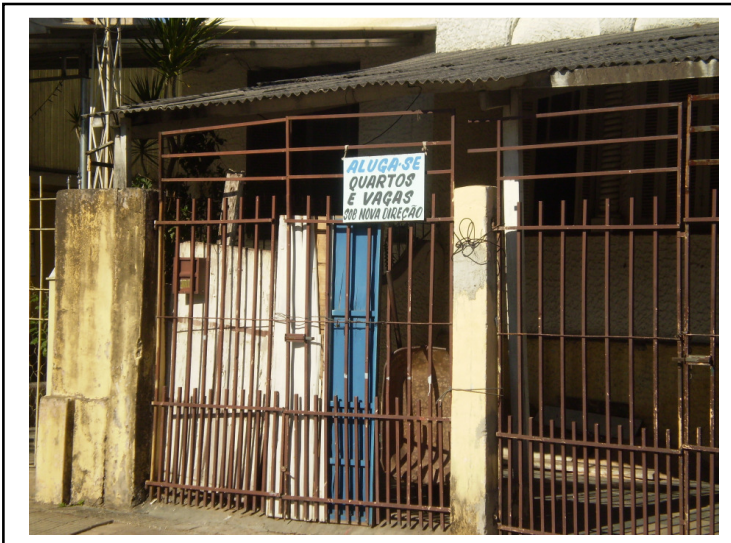

Figura 22 - Concentração de habitações coletivas precárias

Rua Irmã Serafina, nำ249 a 257

Arquivo pessoal - 17 de setembro de 2008. inclusive das demais áreas de estudo.

Em entrevista com a Assistente Social da Creche Bento Quirino, obtivemos a informação que a creche, que deveria atender prioritariamente à população da área central, atende também crianças de bairros localizados na periferia de Campinas. Nesta creche, com cerca de 300 crianças, apenas $20 \%$ são moradoras da área central, sendo algumas moradoras de cortiços. A assistente social aponta a falta de sistematização de dados sobre esta população, que é transitória, como uma das causas para esta contradição. Diz que estas crianças nem aparecem em dados 
censitários, pois vagam de uma "pensão" para outra, ou, muitas vezes, são "escondidas" por seus pais, que as utiliza para aumento da renda familiar. Muitas crianças trabalham junto de seus pais no recolhimento de materiais recicláveis, como "flanelinhas" e guardadores de carros e quando localizadas pelas entidades de fiscalização e combate ao trabalho infantil, são encaminhadas à creche.

Outro ponto importante colocado pela assistente social é a justificativa de atendimento a tantas crianças moradoras de bairros distantes, que se fundamenta no local de trabalho de seus pais: a área central. Em geral, as mães são "domésticas" ou trabalham na limpeza dos estabelecimentos comerciais localizados na área central. Saem de suas moradias muito cedo para poderem chegar ao local de trabalho no horário comercial e são obrigadas a deixar seus filhos na creche mais próxima ao seu local de trabalho, já que quando saem de suas casas, as creches próximas, quando existentes, ainda estão fechadas, o que se dá também no horário de retorno.

Já na área denominada Área $5^{66}$ (Fig. 31), o traçado viário - regular junto à Estação Ferroviária e irregular ao sul - e sua pavimentação, que é de paralelepípedo, não incita um uso intenso, inclusive de pedestres. Apesar de ser uma área localizada junto ao centro da cidade, percebe-se pouco ruído e movimentação. A topografia se apresenta irregular, principalmente no sentido norte-sul.

A ligação com a Área 2 se dá por um antigo túnel subterrâneo que atravessa a Estação Ferroviária, destinado à pedestres. À leste tem-se a Avenida João Jorge e a Rua São Carlos, de fluxo intenso, que se apresenta não só como ligação entre a área em questão e o centro dinâmico da cidade, mas também como eixo de ligação à zona sudoeste, tida como predominante da classe de renda baixa. Nestes eixos viários encontram-se concentrados

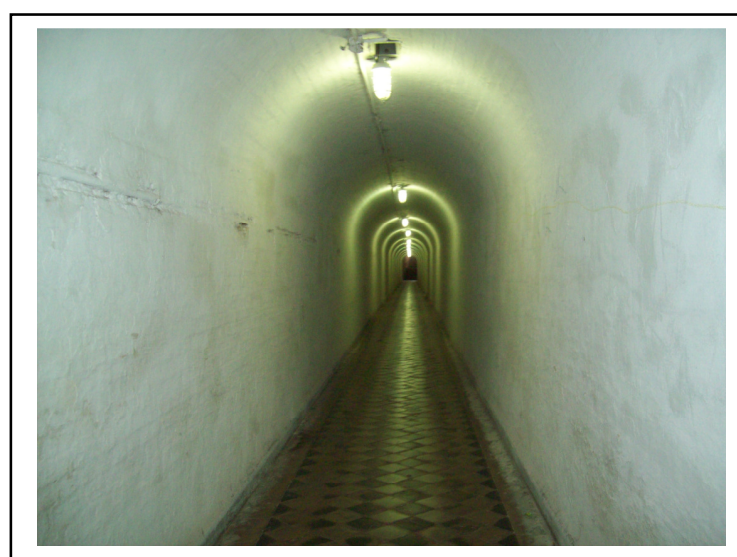

Figura 23 - Túnel subterrâneo para travessia da linha férrea para pedestres Estação Ferroviária Paulista Arquivo pessoal - 22 de janeiro de 2008. comércio, serviços e edifícios altos (até 8 andares).

${ }^{66}$ Delimitado pela Rua Francisco Theodoro (ao norte), Avenida João Jorge (à leste), Avenida Nestor Castanheira, Rua Prudente de Moraes e Rua Engenheiro Pereira Rebouças (à sul) e Rua Antonio Manoel (à oeste). 
Perpendicular a estas ruas, destaca-se também a Rua Dr. Sales de Oliveira, igualmente de fluxo intenso de veículos, que corta a área no sentido leste-oeste. Apesar do grande fluxo, esta rua não apresenta grande quantidade de comércio e serviços, devido, entre outros fatores, à dificuldade de estacionamento.

A área se apresenta como predominantemente residencial, sendo em sua maioria habitada por população de classe de renda baixa e média baixa. Os edifícios ali implantados são de forte interesse histórico arquitetônico, porém com alto grau de degradação. Em geral são casas térreas. Nas quadras junto à Estação Ferroviária a fachada fica junto ao alinhamento do lote, mas conforme se avança em sentido sul percebe-se o uso de recuo frontal, protegido por gradil baixo. A Estação Ferroviária se coloca como forte barreira física para a população que ali reside e que usa e trabalha na Área 1, porção mais dinâmica do centro da cidade, e na Área 2.

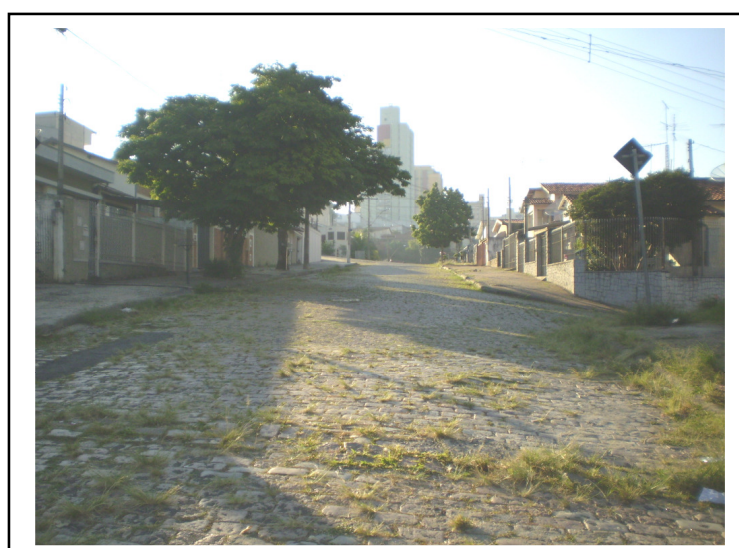

Figura 24 - Vista geral Área 4

Rua 24 de Maio com Rua Monteiro Lobato Arquivo pessoal - 12 de maio de 2008

Nesta área de estudo também não encontramos placas ou outras formas de anúncio que apresentem tais edificações como pensões ou hotéis populares, embora existam anúncios de locação de vagas escritos informalmente, à mão livre, em pedaços de papel ou papelão. Durante a pesquisa observou-se nos horários de abertura e fechamento dos estabelecimentos comerciais da área central um grande número de ambulantes, saindo de algumas casas localizadas na área em questão, carregados de mercadorias, e caminhando em direção ao túnel de ligação (para pedestres) com a Área 2. Alguns destes ambulantes foram abordados e declararam seus locais de moradia como habitados coletivamente e de forma precária, e apontaram a proximidade com o local de trabalho o principal fator para ali residirem, mesmo diante das condições precárias descritas.

Destacam-se ainda, a Vila Manoel Dias, construída em 1908, e a Vila Manoel Freire, construída em 1918, antigas vilas operárias associadas à instalação das Companhias de Estrada de Ferro Paulista (1872) e Mogiana (1874), que são bens tombados e hoje reúnem moradias coletivas em estado altíssimo de degradação. $\mathrm{Na}$ abordagem realizada junto a alguns moradores atuais das vilas, foi declarado 0 
comércio informal de vagas e cômodos. Nesta área surgiu, pela primeira vez, a palavra cortiço na tentativa de descrição e caracterização da moradia, por parte de alguns moradores. Os quarteirões próximos às vilas, também apresentam grande número de unidades habitadas coletivamente e de forma precária.

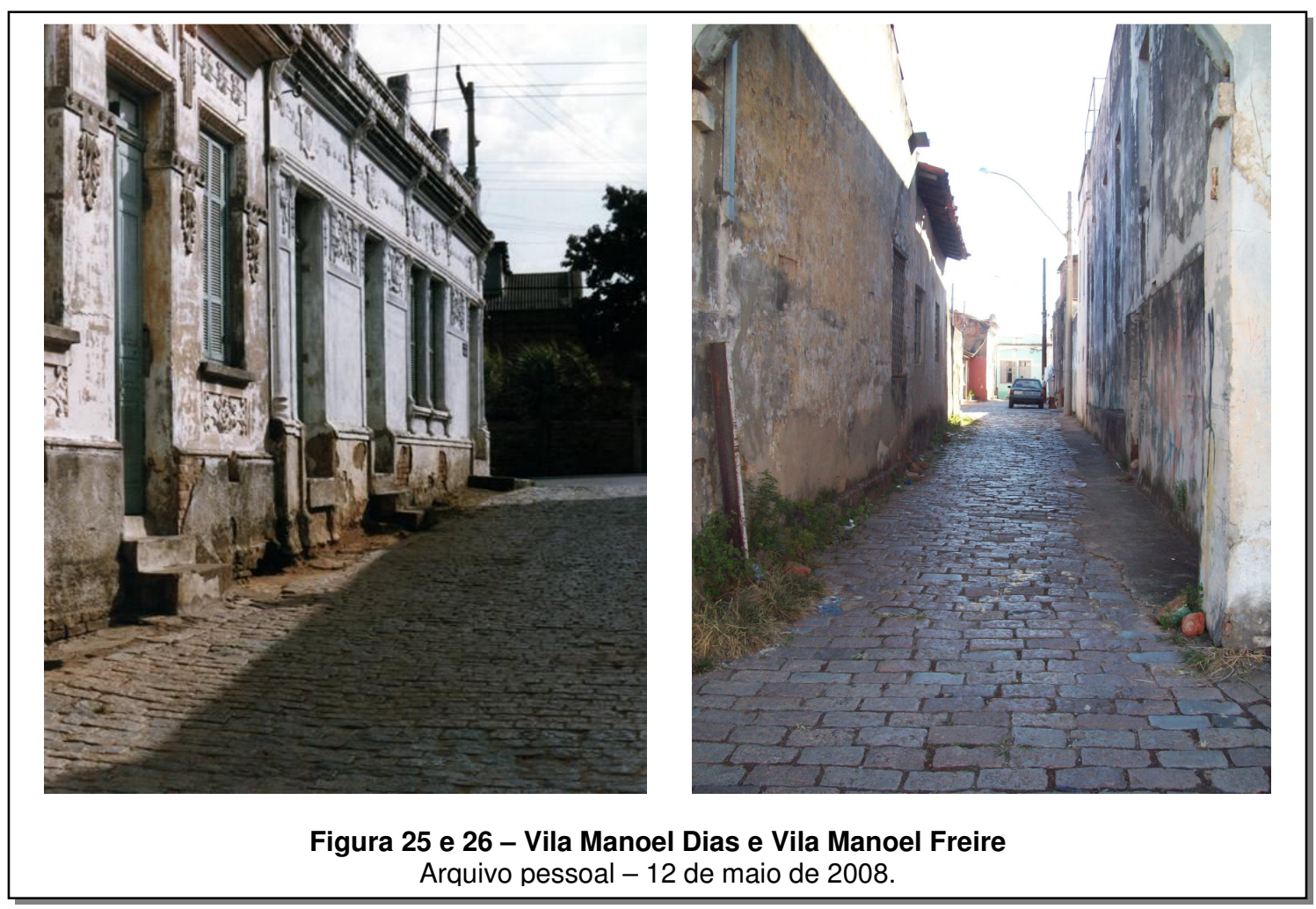

Outro ponto de destaque é a presença de uma ocupação ilegal, na Rua Eng. Pereira Rebouças. De um lado da rua, em quarteirão integrante da área de estudo, observou-se algumas unidades habitadas coletivamente, e durante a coleta de depoimentos, soubemos que se tratava de invasões de casas que se encontravam abandonadas. Do outro lado da rua, em área já não constante do perímetro de estudo abordado, registrou-se um grande número de barracos de madeirite, chão de terra batida, grande número de moradores, inclusive com muitas crianças, vivendo em estado crítico. Deste local, também encontramos muitos ambulantes que todos os dias dirigem-se à Área 2 e "centro dinâmico" da cidade para a venda de seus produtos.

A área apresentou, segundo pesquisa de campo realizada "in loco", 143 habitações coletivas - concentradas principalmente junto às vilas citadas, 25 edifícios degradados e/ou vazios, 2 hotéis aparentemente mais formalizados e 8 estacionamentos particulares (cf. Fig. 31). 
$\mathrm{Na}$ área denominada Área $6^{67}$ (Fig. 32), encontra-se o parque férreo da Estação Mogiana, e um conjunto de casas simples e pequenas, construídas na época de sua implantação para os trabalhadores, constituindo outra vila operária. Esta vila foi invadida por famílias de classe de renda baixa que as ocupa coletivamente e hoje, converteram-se em alvo de grande embate político. Outras casas foram construídas no local, igualmente de forma precária, e algumas sofreram ampliações.

Há uma passagem de acesso para pedestres e veículos de pequeno porte, como bicicleta ou motos, no final da Rua Prof. João Lourenço Rodrigues, ponto onde se nota esgoto correndo à céu aberto. Ao passar pelo acesso, entramos no que seria a continuação da rua citada. Porém, neste trecho, que tem cerca de duzentos metros, não há asfaltamento, nem passeio público construído. Em alguns pontos, o paralelepípedo antigo ainda está assentado. A rua, que de tão larga assemelha-se a um pátio de uso comum das casas que se voltam a ela, é de terra, com bastante mato nas duas laterais e lixo espalhado por toda parte. Muitas crianças brincam no local. De um lado da rua encontram-se às fachadas das casas invadidas e do outro o fundo das casas voltadas para a rua de cima. Aí começamos a perceber o grande contraste que a área apresenta, já que as demais ruas, no sentido noroeste, configuram-se ruas bem asfaltadas e

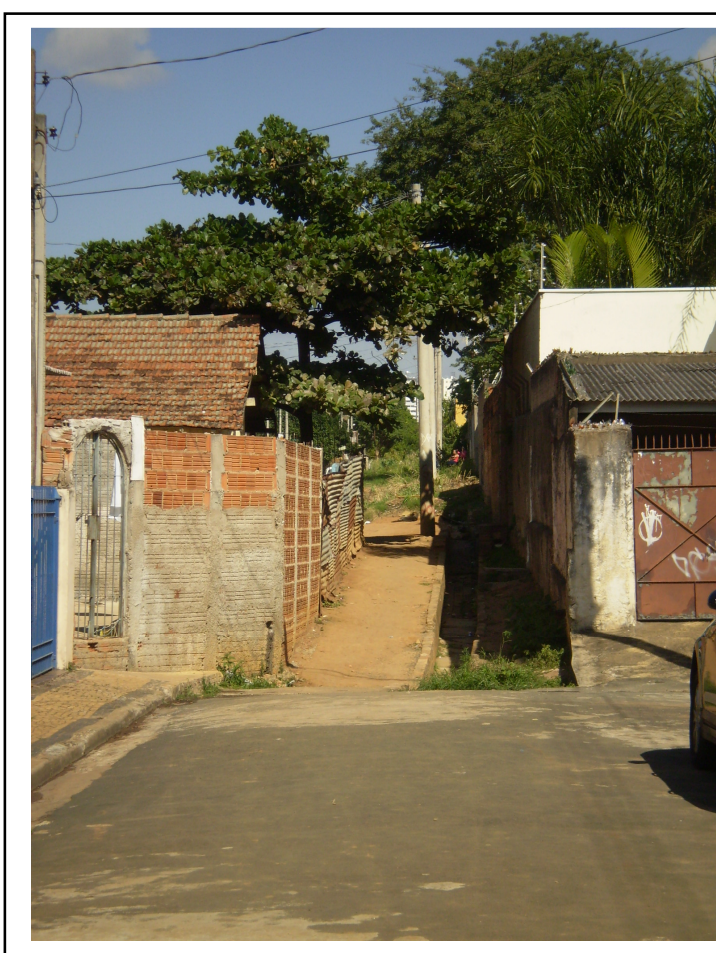

Figura 27 - Passagem para vila operária da Estação Ferroviária Mogiana

Rua Professor João Lourenço Rodrigues Arquivo pessoal - 12 de maio de 2008. arborizadas, com casas antigas de grande valor histórico arquitetônico de médio e alto padrão, que, "de repente", desembocam na larga rua de terra batida, com elevado grau de degradação.

A área apresentou, segundo pesquisa de campo realizada "in loco", 46 habitações coletivas, que correspondem às antigas casas operárias - ainda que

\footnotetext{
${ }^{67}$ Delimitada por Avenida Brasil (à nordeste), Avenida Barão de Itapura (à sudeste), Rua Cândido Gomide (à sudoeste) e Rua Camargo Paes (à noroeste).
} 
algumas tenham sofrido acréscimos e alterações consideráveis. Para os demais itens levantados pela pesquisa não foram diagnosticados uso (cf. Fig. 32).

Com toda a área de estudo devidamente assimilada e caracterizada, foram identificados os imóveis ocupados por habitação coletiva precária. Como expresso anteriormente, em algumas áreas tais edificações se apresentam como pensões e hotéis populares, através do uso de luminosos, placas simples e, às vezes, até informais, escritas à mão em pedaços de papel ou papelão. Em geral, trazem as seguintes informações: o nome do lugar, telefone e restrições, como por exemplo, a recusa em aceitar casais com crianças, e até mesmo restrições ligadas a gênero.

Além deste tipo de unidades, observaram-se também outras edificações ocupadas em iguais ou similares condições, mas que não declaram de forma tão explícita o comércio de locação de cômodos ou vagas. Algumas características, no entanto, se fazem notar e revelam seu uso, e permitem uma primeira caracterização. São elas: deterioração física; fiação elétrica exposta e danificada; grande movimentação de pessoas, inclusive de um edifício para outro de semelhante funcionamento; roupas estendidas em varais em grandes quantidades e de forma exposta; lixos e entulhos amontoados na entrada do edifício; carrinhos de coleta de lixo reciclável nos corredores laterais internos ao lote, ou no passeio público defronte do imóvel, e em alguns casos, a presença de uma grande caixa d'água instalada no que seria a garagem ou recuo frontal do lote. Estão instaladas normalmente em vias de pouca movimentação, estreitas e com pavimentação de paralelepípedo. Alguns moradores foram abordados e confirmaram o comércio de locação de vagas e cômodos existente nestas edificações. São locais já conhecidos por parte da população que geralmente faz uso deste tipo de habitação e por isso, dispensam placas indicativas.

Tais edificações, identificadas de maneira geral enquanto habitações coletivas populares, diferenciam-se em certas especificidades. Apresentam, entretanto, tantas porosidades ou permeabilidades entre as questões, que dificultam sua caracterização ou a determinação de tipologias. Para tanto, considerou-se além dos aspectos construtivo-arquitetônicos, seus atores e os embates vividos pelos mesmos, as regras internas estabelecidas, as formas de apropriação e o jogo mercadológico que as promove em meio ao cenário de transformações sofridas pelas áreas centrais metropolitanas. Tais aspectos são analisados no capítulo a seguir. 


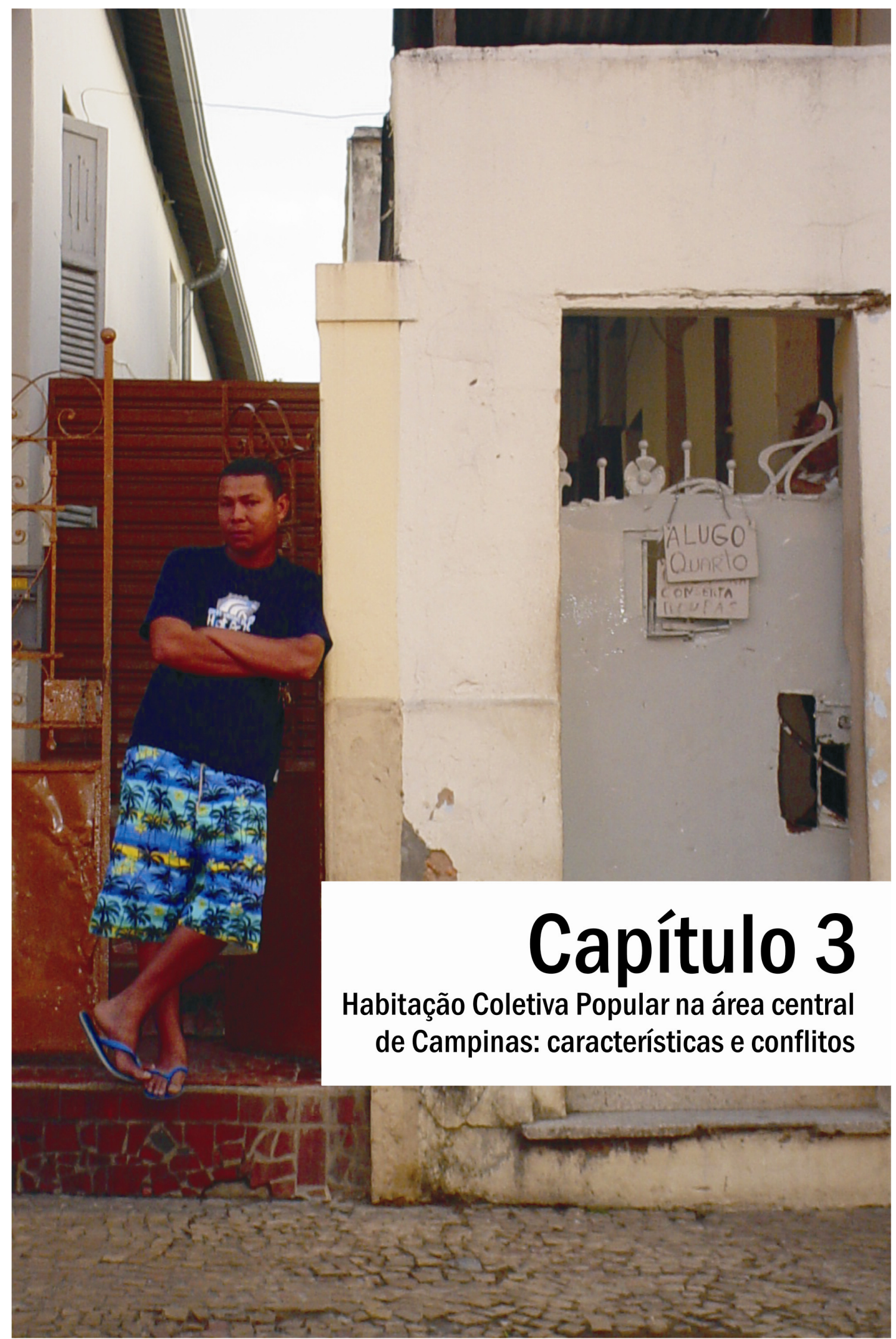




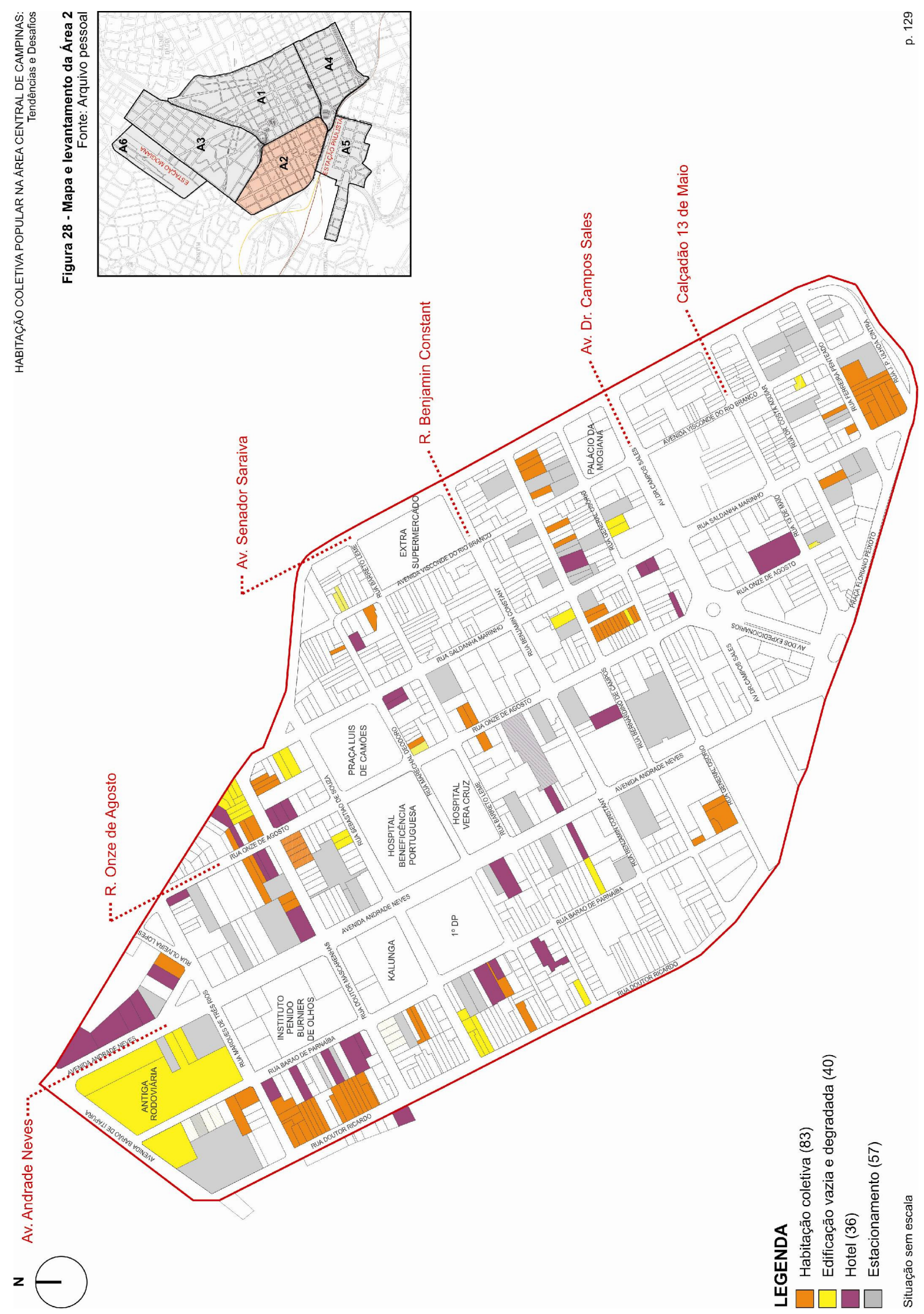




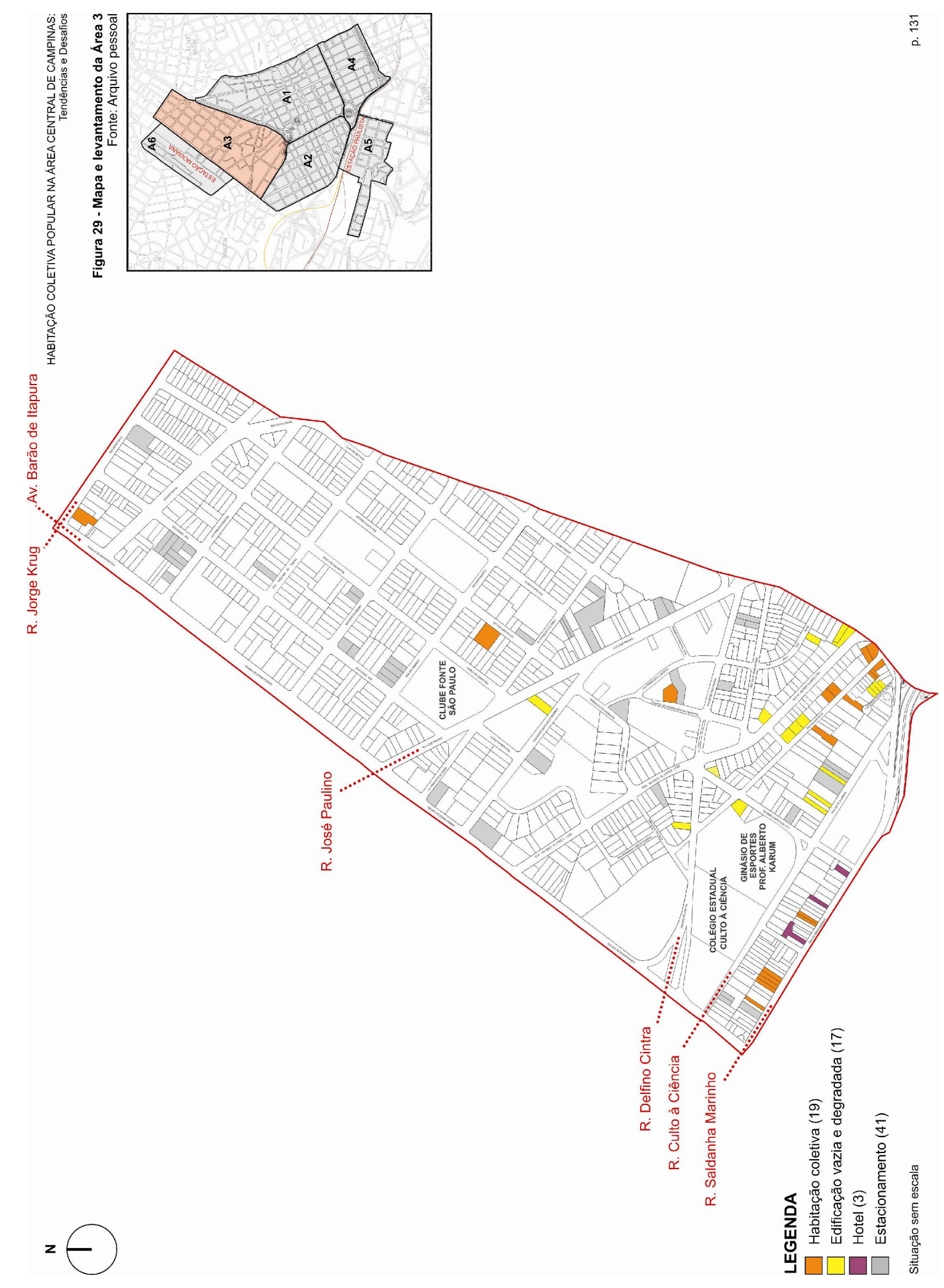




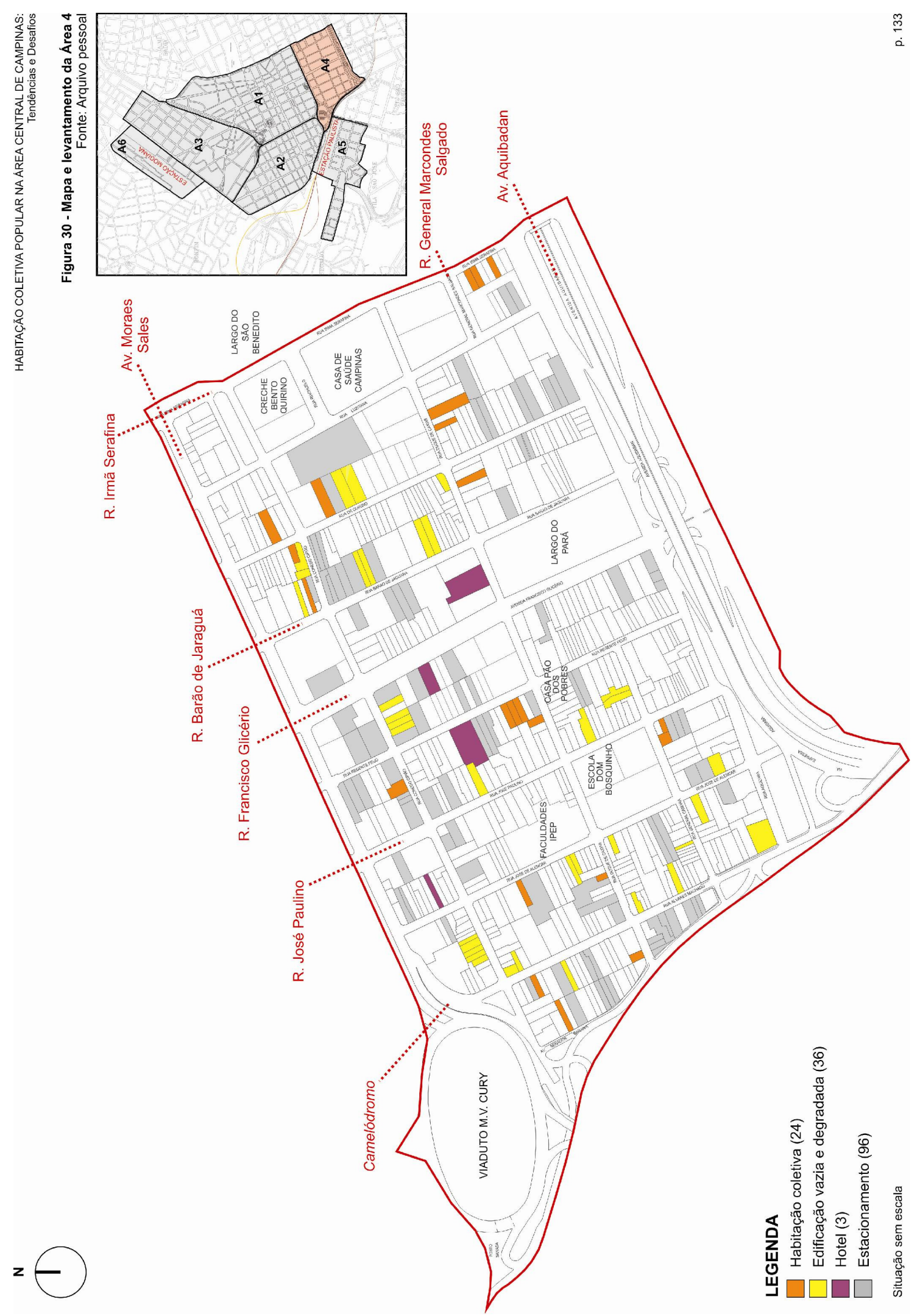




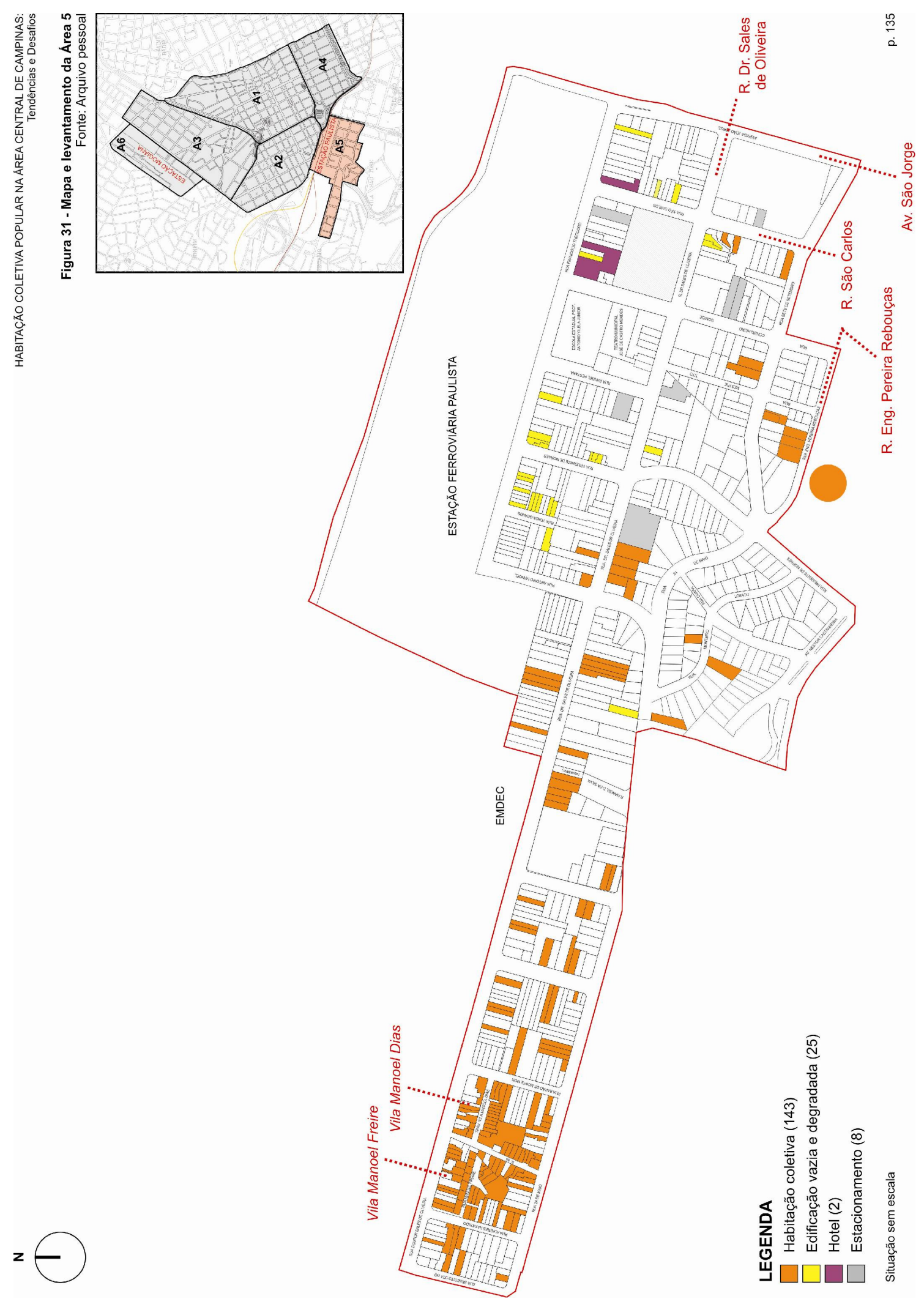




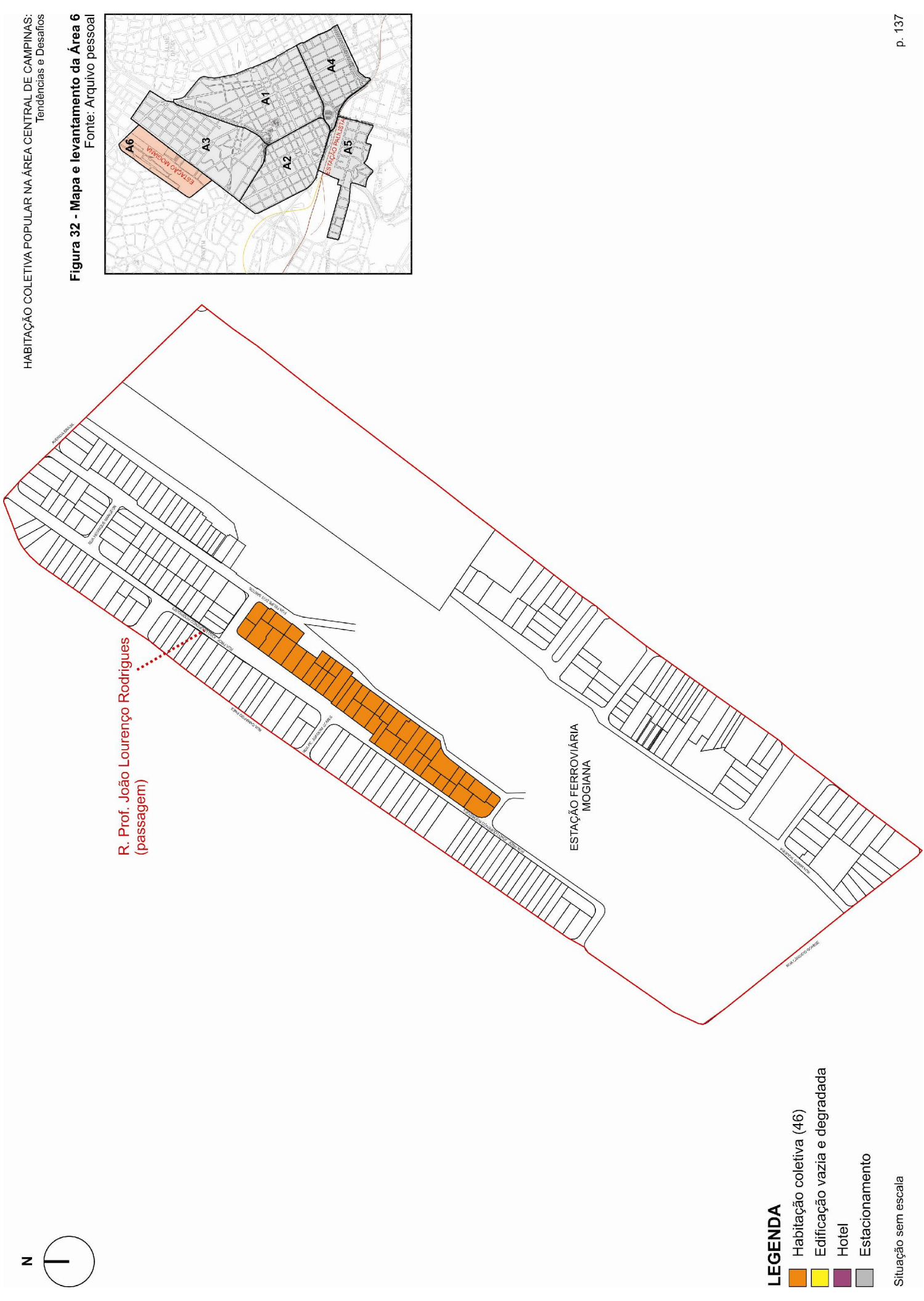




\subsection{Caracterização quanto às características físicas e condições do imóvel}

A caracterização das moradias coletivas populares existentes na área central de Campinas implica em desvendar suas formas e usos. Em termos da forma, podem ser caracterizados quanto à tipologia - prédio, casa, correr de quartos, etc. - e quanto à condição do imóvel - construção degradada, abandonada ou inacabada. No que se refere aos usos ou formas de ocupação, a pesquisa identificou três modalidades básicas: cortiços, pensão/ hotel e invasão.

A permeabilidade entre os diferentes aspectos que caracterizam tais modalidades de moradia é considerável, e demonstra a necessidade de abordagem da questão a partir de diversos pontos de vista para que se tenha uma leitura mais condizente com esta realidade que se apresenta em constante processo de transformação. Para tanto, mais do que analisar tais moradias a partir de seus aspectos físicos - tipologia e condições do imóvel -, e de seus usos, a pesquisa também procurou caracterizar as diferentes configurações de habitação coletiva popular, existentes na área central de Campinas, a partir dos conflitos e aspectos ligados às relações estabelecidas entre os diversos atores envolvidos na questão.

Uma primeira possibilidade, portanto, de caracterizar as unidades apontadas se dá a partir do destaque às condições dos imóveis, complementada pela divisão tipológica. A estas, relacionam-se fatores como grau de manutenção e degradação, que implicam em questões relacionais e condições de habitabilidade. Além disso, observa-se a importância histórico-arquitetônica de boa parte dos imóveis identificados como habitações coletivas populares, revelando o quadro de descaso com o patrimônio construído. Um dos pontos observados é que, em geral, nas habitações coletivas populares apontadas pela pesquisa, a precariedade é um dos aspectos comuns às diversas tipologias habitacionais populares. Porém esta precariedade pode estar relacionada a diferentes questões, determinantes na diferenciação das configurações habitacionais encontradas. São estas que procuraremos abordar neste item, identificando como se manifestam nas diferentes tipologias habitacionais. 


\subsubsection{Edificação degradada}

Em geral, todas as edificações apontadas como de uso habitacional coletivo popular, apresentam alto grau de deterioração. Isso se dá pela falta de investimentos em manutenção, pelas muitas adaptações construtivas - como acréscimo ou alterações no dimensionamento de cômodos, "gatos" junto à rede de fiação elétrica, adaptações hidráulicas para provimento de mais conjuntos hidro-sanitários, etc. - que vão sendo executadas sem planejamento, sem muitos recursos disponíveis ou acompanhamento de um profissional habilitado. Normalmente, estas adaptações ou arranjos construtivos são feitos pelos próprios moradores em troca de isenções de pagamento de aluguel por tempo determinado ou de algumas regalias dentro das regras de convívio interno, como tempo de uso do banheiro, por exemplo.

Neste item, procuramos destacar as edificações que, apesar do nível de degradação, estão inseridas em um conjunto de edificações de grande interesse histórico, cultural e arquitetônico. Algumas se apresentam de forma isolada na quadra, tendo em vista as transformações ocorridas na configuração da área central de Campinas ao longo do tempo e o processo de demolição e construção de novas edificações, inclusive ligadas a outros usos que não o habitacional.

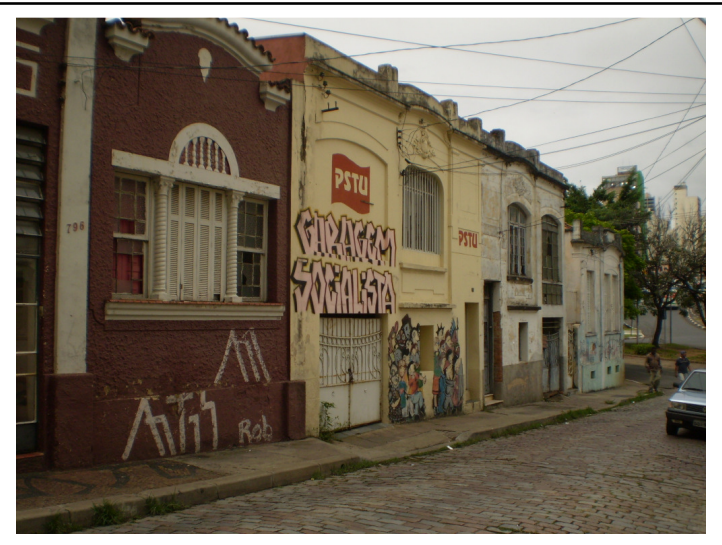

Figura 33 - Conjunto arquitetônico (imóveis tendo uso habitacional coletivo)

Rua Marechal Deodoro, no 776, 784, 786, 796

Outras compõem, junto às edificações de características similares localizadas no entorno, conjuntos arquitetônicos de grande interesse histórico produzidos por engenheiros-arquitetos e construtores no período compreendido, sobretudo, entre às décadas de 1870 e 1930.

Seus proprietários normalmente moram no próprio imóvel ou em imóveis próximos. No primeiro caso, o proprietário, em geral, é de classe de renda baixa ou média baixa, cuja única propriedade muitas vezes é aquela edificação deteriorada que ainda lhe serve como moradia na área central. Para ele, a locação de cômodos ou 
vagas é a alternativa encontrada para garantir sua subsistência, a manutenção do imóvel - ainda que insuficiente - e o pagamento de taxas incidentes sobre o mesmo.

No segundo caso, o proprietário já deixou a área central tendo em vista outras regiões da cidade enquanto local de moradia, e vê, na locação de cômodos ou vagas, uma forma de adquirir algum rendimento, além de manter o imóvel ocupado e, assim, evitar uma depredação mais aguda. O uso coletivo, através desta atividade de locação, se dá, normalmente, através de um administrador ou intermediário, nestes casos, enquanto o proprietário aguarda momento mais oportuno, em termos de lucratividade, para a venda do imóvel. Observa-se que tais imóveis, gradativamente vão sendo adquiridos pelas grandes incorporadoras atuantes da região, formando conjuntos de terrenos que, quando englobados, são de grande interesse especulativo e deflagram a centralização da propriedade. Até a formação desses conjuntos de terrenos, as incorporadoras mantêm os imóveis em alto grau de deterioração, estimulando o uso coletivo de modo a estimular o processo de degradação e a conseqüente desvalorização dos imóveis vizinhos, além de adquirir recursos para pagamento de impostos e taxas incidentes sobre os mesmos. Outra

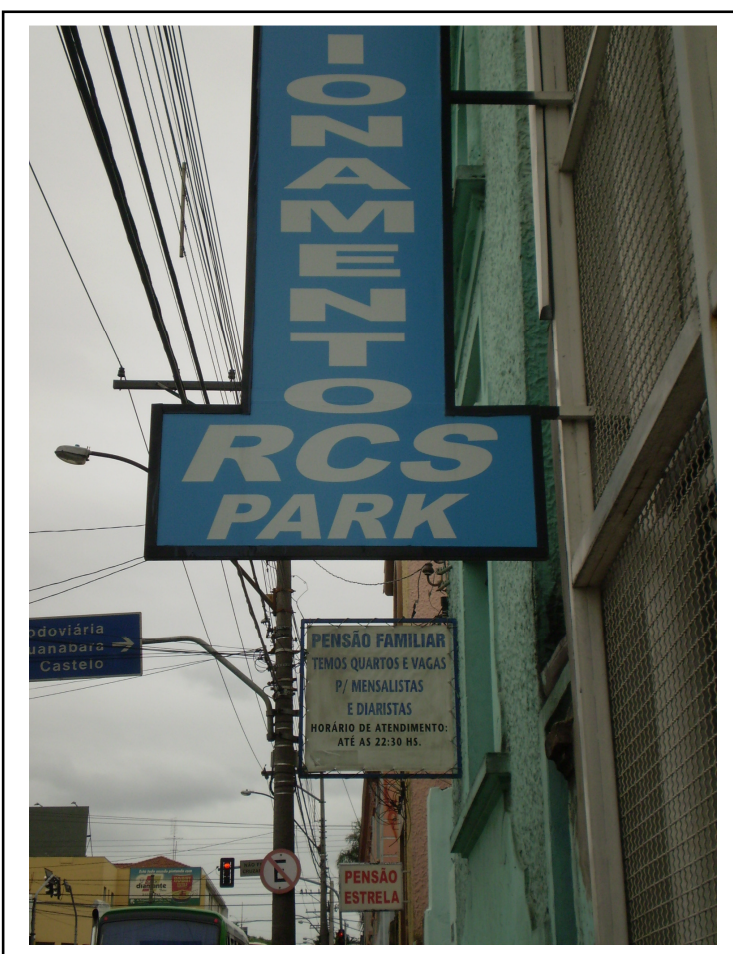

Figura 34 - Seqüência de imóveis: "Pensão Estrela", "Pensão Familiar" e Estacionamento "RCS Park"

Rua Dr. Mascarenhas, no 387, 391, 415 Arauivo pessoal -22 de ianeiro de 2008. conseqüência para estes imóveis é sua demolição e substituição de uso, já que em geral transformam-se em estacionamentos particulares, cuja lucratividade adquirida teria a mesma finalidade. Não há preocupação com a preservação do patrimônio histórico ou de interesse arquitetônico, nestes casos. Ao contrário, as incorporadoras trabalham em sentido contrário à preservação, sendo comuns histórias de demolição durante a madrugada de forma a não despertar a reação de grupos de defesa do patrimônio construído. 


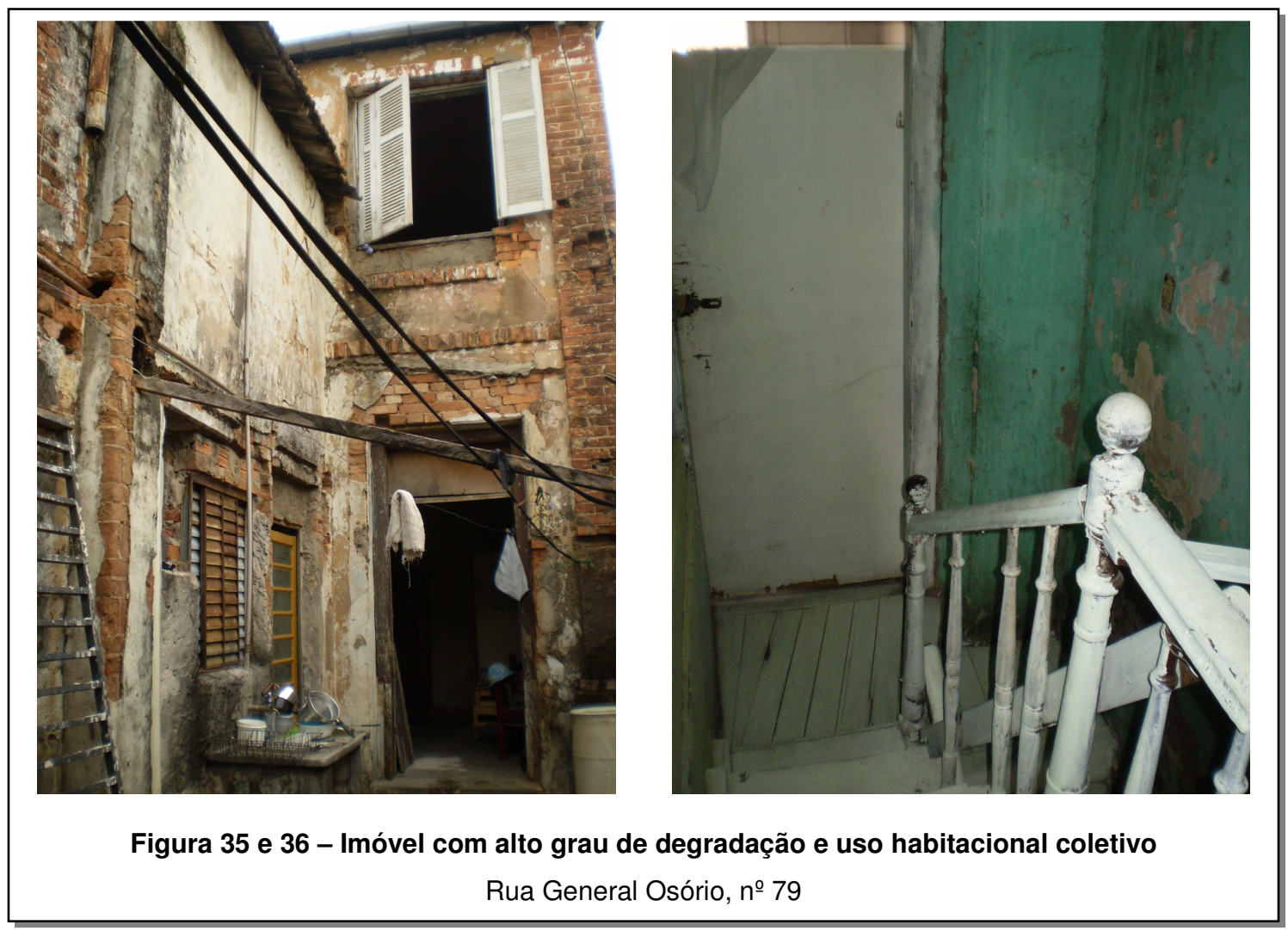

Neste sentido, destacamos o estudo desenvolvido pela Coordenadoria Setorial de Patrimônio Cultural (CSPC), da Secretaria Municipal de Cultura de Campinas, com apoio da FAPESP, que realizou um extenso inventário dos bens culturais situados na região central de Campinas $^{68}$, guiando-se pelas diretrizes adotadas no "Inventário Nacional de Bens Imóveis dos Sítios Urbanos Tombados (INBI-SU)", desenvolvidas pelo Instituto do Patrimônio Histórico e Artístico Nacional (Iphan), desde 1998 (MINC/IPHAN, 2001) $)^{69}$.

O estudo destaca a Resolução $n^{\circ}$. 04/90 do Condepacc, que dispõe sobre 0 tombamento do Complexo Ferroviário Central de Campinas, e da decorrente fragilidade desta figura. Ao menos durante a primeira década de atuação do

\footnotetext{
${ }^{68}$ Foram visitados e inventariados cerca de 760 imóveis, dentre os quais aproximadamente 250 foram selecionados para estudos detalhados que ora compõem as relações apresentadas para a abertura de processos de tombamento. O estudo foi finalizado em 2008.

${ }^{69}$ Dados sobre a metodologia de trabalho e os resultados obtidos pelo órgão federal de preservação podem ser conferidos em www.iphan.gov.br. Sobre o assunto conferir também MINC/IPHAN, 2005.
} 
Condepacc, foi comum o emprego do termo "preservado" nas resoluções de tombamento, utilizado para designar bens situados na área envoltória dos bens tombados que não poderiam ser modificados ou demolidos sem prévia autorização do conselho, em diferentes graus (preservação total, preservação de fachada e/ou volumetria, por exemplo). Na prática, esses imóveis ficavam, muitas vezes, submetidos às restrições impostas a um imóvel tombado, sem que o fossem juridicamente. Por outro lado, não caberiam aos proprietários os benefícios concedidos àquela figura, como a concessão de isenção de imposto predial territorial urbano (IPTU) ou a possibilidade de concorrer a linhas de financiamentos para recuperação dos imóveis. 


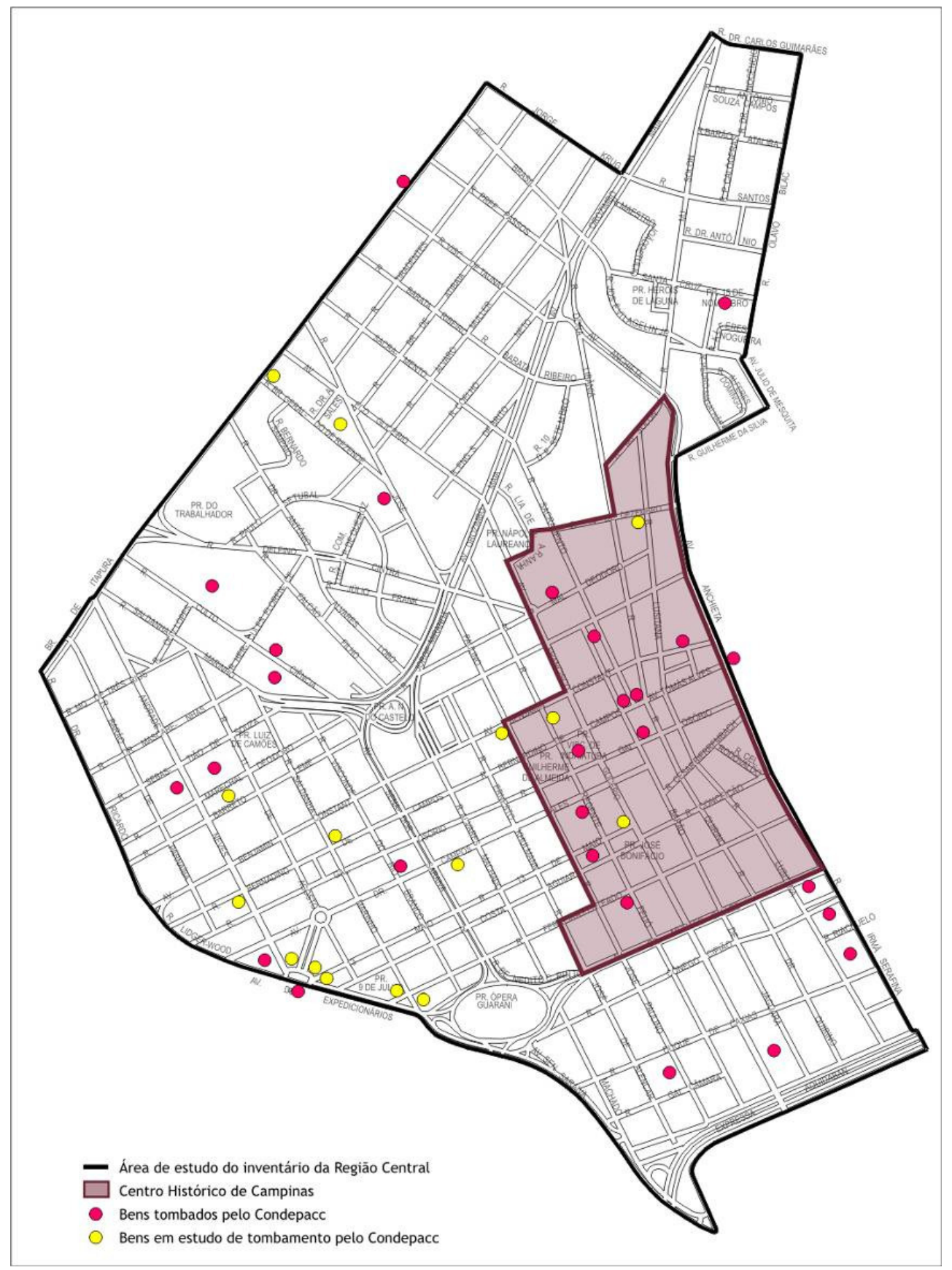

Figura 37 - Mapa com a delimitação da área de estudo do "Inventário da Região Central de Campinas"

Fonte: informação pessoal. Prefeitura Municipal de Campinas. "Inventário da Região Central de Campinas". Campinas, 2008. Relatório Final. Mensagem enviada pela Arq. Rita Francisco, Agente Cultural - CSPC/SMCEL/PMC, para cmcara@hotmail.com em fevereiro de 2009.

Além disso, o estudo da CSPC verificou que muitos dos imóveis "preservados" em resoluções se encontram desfigurados. Por esse motivo abrangeu uma completa revisão dessa situação, culminando com o tombamento daquelas edificações significativas e ainda íntegras - individualmente ou em conjuntos urbanos - e a 
retirada da listagem daquelas descaracterizadas ou mesmo demolidas parcialmente das respectivas resoluções em que estiverem arroladas nos termos ora descritos.

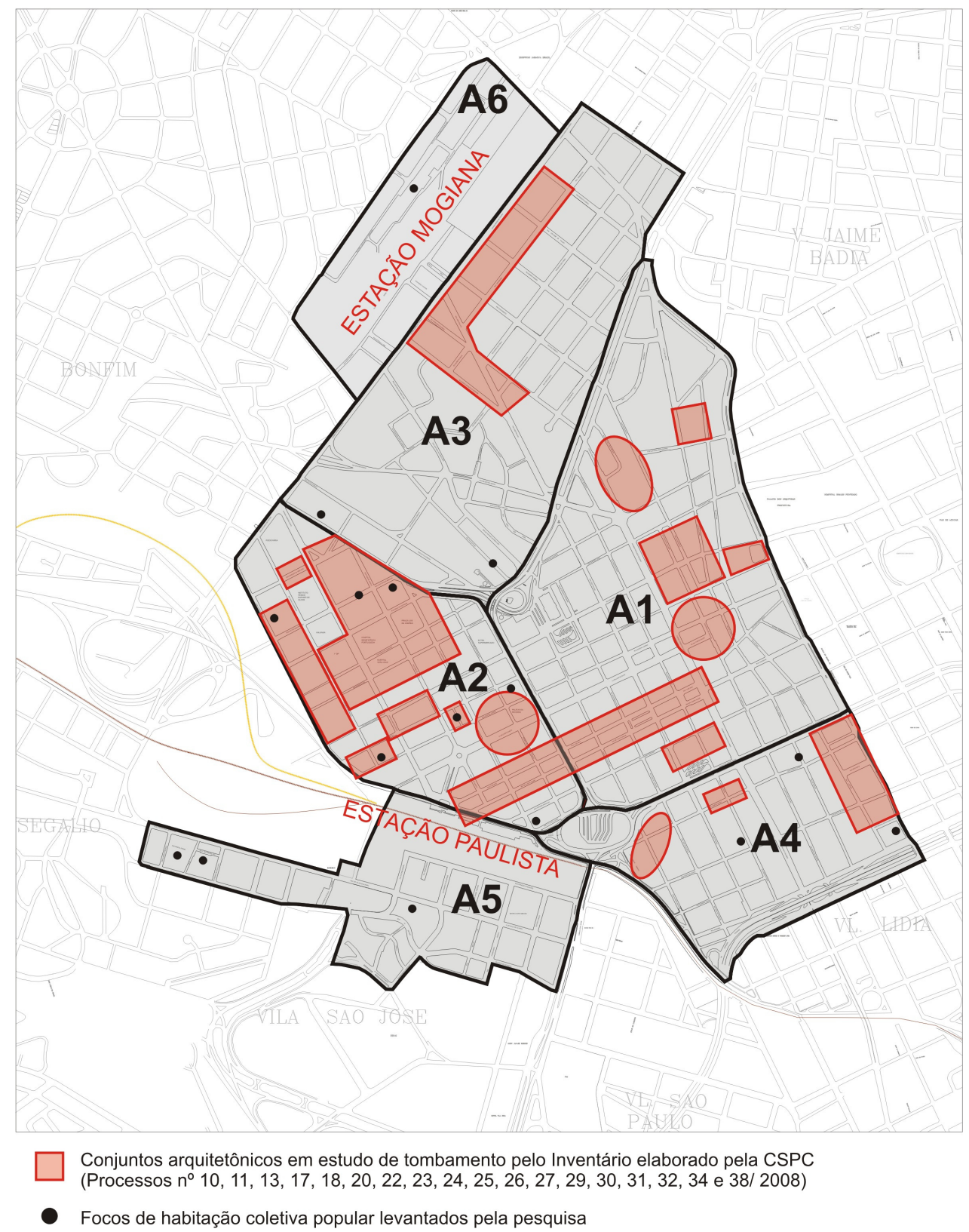

Figura 38 - Perímetro de Estudo adotado para a pesquisa, com cruzamento dos dados resultantes do "Inventário da Região Central de Campinas" e pesquisa de campo

Fonte: Arquivo pessoal, com base no Mapa geral dos conjuntos em estudo de tombamento (In: Prefeitura Municipal de Campinas. "Inventário da Região Central de Campinas". Campinas, 2008, prancha 1/30. Relatório Final. Mensagem enviada pela Arq. Rita Francisco, Agente Cultural - CSPC/SMCEL/PMC, para cmcarq@hotmail.com em fevereiro de 2009) 
Vale ressaltar que, em pesquisa executada junto ao setor de cadastro da prefeitura e demais órgãos pertinentes, boa parte destas adaptações construtivas não passam por processo de aprovação ou regularização junto à prefeitura. Não há também indícios de fiscalização que atuem no sentido de verificar a área mínima resultante dos cômodos, área de ventilação e iluminação mínimas, largura de corredores, número de conjuntos sanitários, etc. A fiscalização também não passa pela existência ou não de alvará ou licença de funcionamento e outros documentos relacionados à ao uso atual destas edificações.

Também destacamos a presença de outras edificações que, pelo contrário, não apresentam interesse histórico-arquitetônico por suas características construtivas, nem são relacionadas diretamente a um conjunto arquitetônico urbano ou a determinado momento histórico-cultural de interesse. Ainda assim, são relevantes, e compõem,

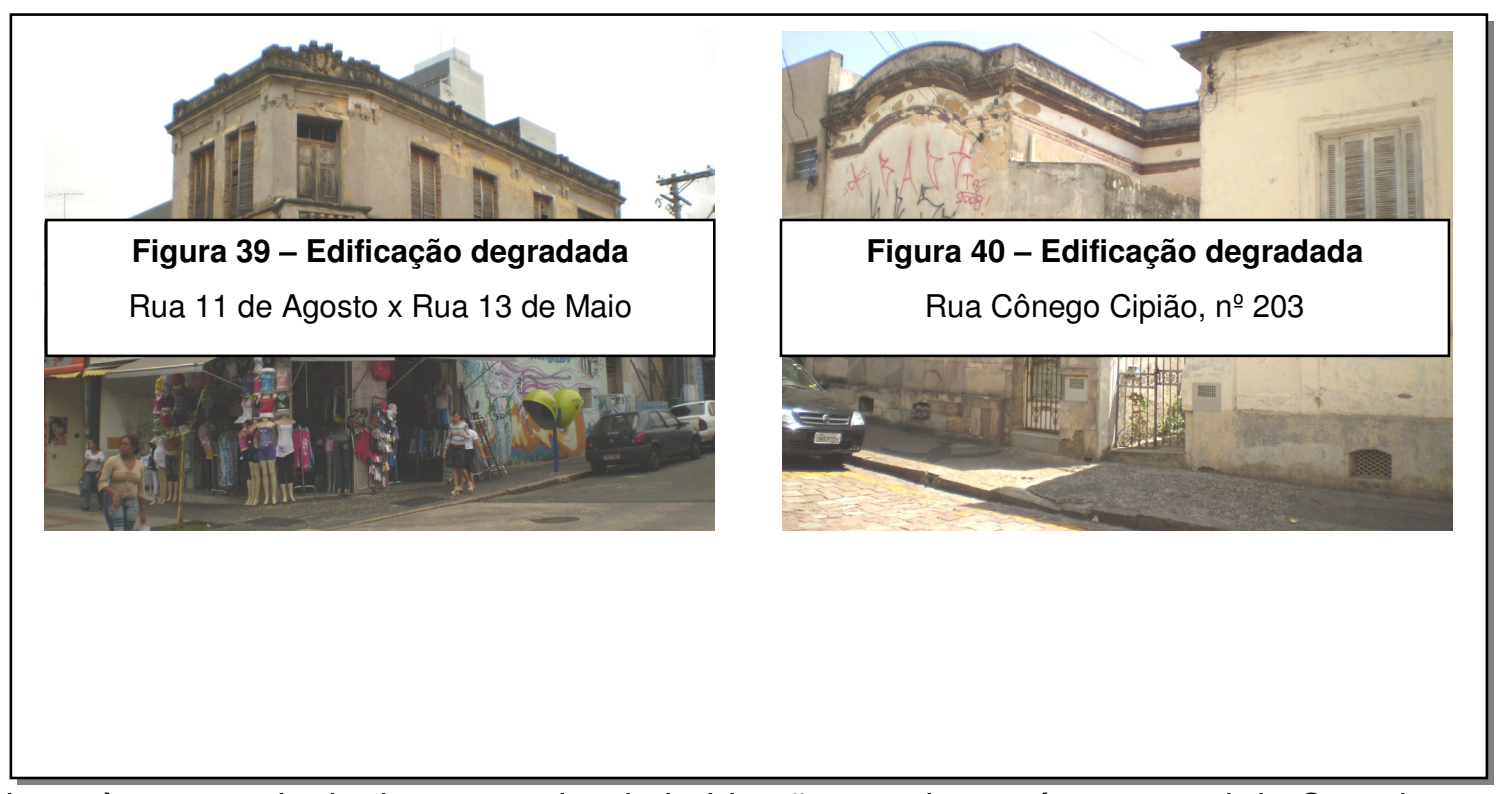

junto às outras tipologias, o quadro da habitação popular na área central de Campinas.

\subsubsection{Edificação inacabada}


Encontramos no perímetro de estudo algumas edificações inacabadas, ou seja, construídas até certo ponto e abandonadas pelos mais variados motivos normalmente relacionados à falta de recursos financeiros. Tais edificações têm como proprietários grandes incorporadoras, inclusive estrangeiras - no caso dos edifícios altos (com mais de oito pavimentos) - ou particulares, moradores de imóveis localizados em outras regiões da cidade. Estas últimas, geralmente são casas de um ou dois pavimentos. Em geral, após algum tempo de abandono por parte de seus respectivos proprietários, são ocupados por processo de invasão. Porém, depois de invadidas podem assumir as características de pensão, com locação de cômodos e vagas, e submissão a determinadas regras de convívio interno próprias desta forma de apropriação como veremos adiante. Essa alteração na configuração do uso do imóvel, normalmente acontece quando o proprietário toma ciência da invasão e vê, no uso habitacional coletivo, através da locação de cômodos e/ou vagas - ainda que a construção não tenha chegado ao fim -, oportunidades de ganhos temporários

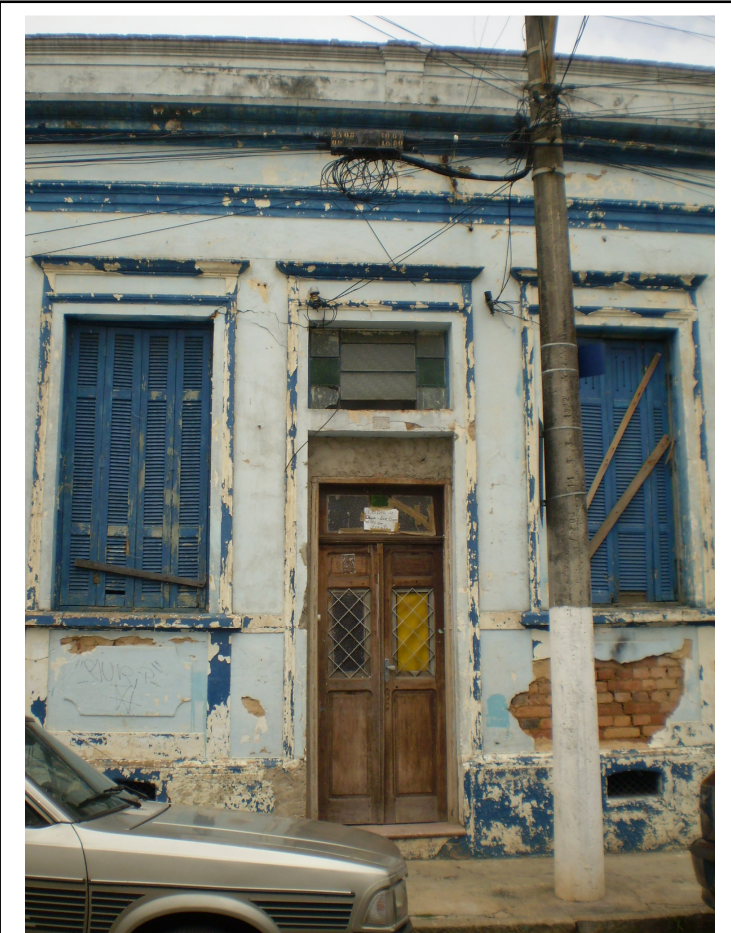

Figura 41 - Edificação degradada com incidência de ocupação por invasão

Rua Visconde do Rio Branco, no 777 Arquivo pessoal - 22 de janeiro de 2008. com o imóvel.

Aqui também o alto grau de degradação, até pelo caráter inacabado da construção, é notável. Quando invadido, é comum o uso de madeirites, lonas, papelão e cadeados instalados juntos aos fechamentos de forma a proteger o interior da edificação de ventos, chuvas, etc., já que não há presença de esquadrias. Outra justificativa para o uso destes artifícios, além de outros arranjos construtivos complementares, é a questão da segurança da edificação, que deve estar assegurada de forma a evitar a entrada de outros moradores de forma indiscriminada, nos períodos em que os ocupantes estejam ausentes. 
Os três edifícios altos encontrados nestas condições encontram-se na Área 3, que, como visto anteriormente, é uma área com acentuada verticalização voltada para o uso habitacional de classe de renda média e média-alta. E é junto a esta parcela da população que os moradores de edifícios inacabados encontram sua principal fonte de renda: a reciclagem de lixo. Por isso, junto a estas edificações é comum observarmos grande acúmulo de lixo e carrinhos de coleta de lixo reciclável, além de espaços destinados a separação do material. O mau cheiro junto a estas edificações é bastante forte, dada estas características.

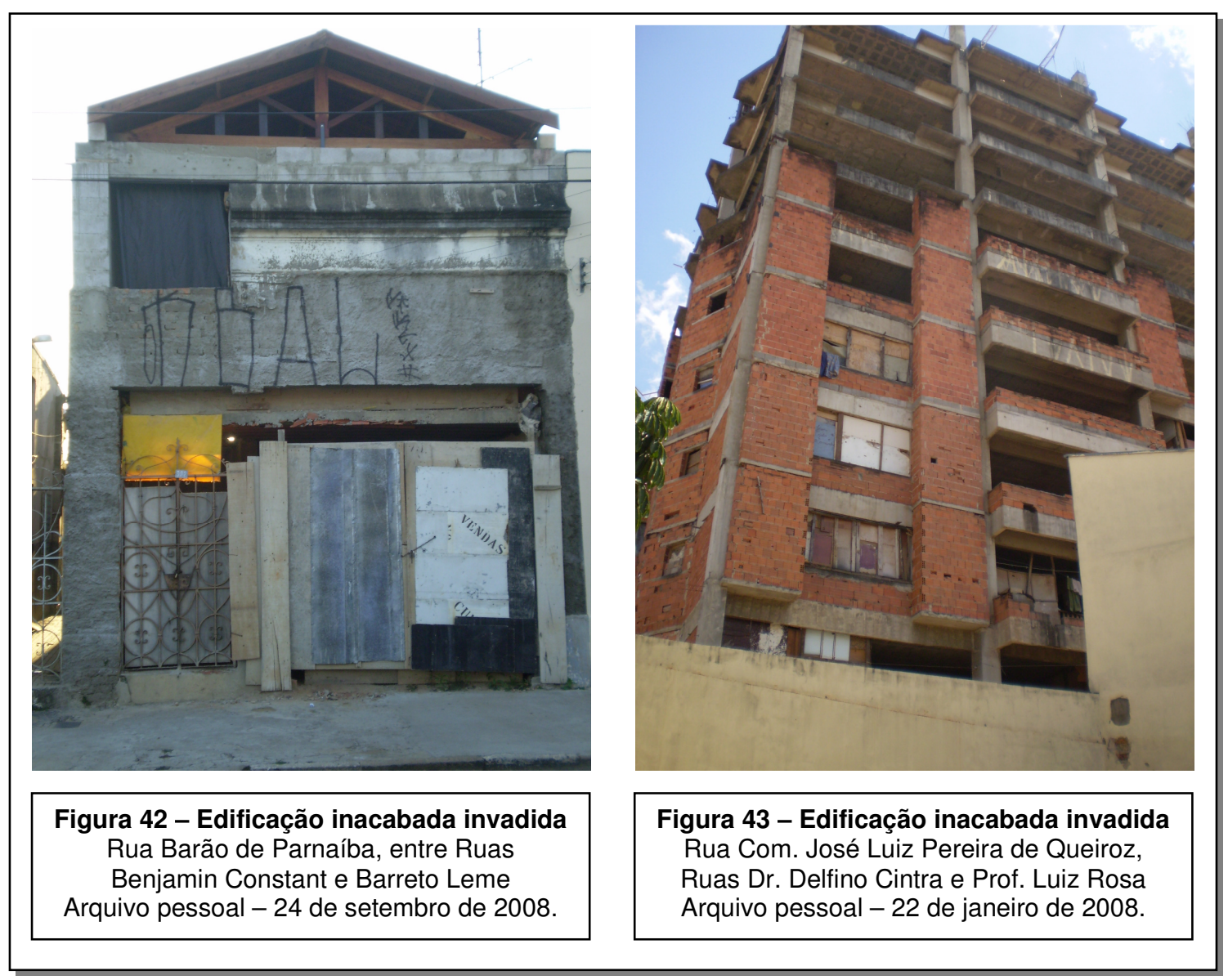




\subsubsection{Edificação abandonada}

Diante do processo de transferência das classes mais abastadas e da classe de renda média para outros setores da cidade, muitos imóveis encontram-se abandonados na área central à espera de compradores, ou disponíveis à locação, que em geral se dá pela transferência de uso habitacional para comercial ou ligado à prestação de serviços.

Enquanto o negócio não parece lucrativo ou aguarda valorização, o imóvel fica vazio, tendo suas aberturas fechadas por alvenarias para evitar invasões, e o proprietário pode eventualmente acumular dívidas diante dos altos impostos que incidem sobre os imóveis da área central. Observamos que, em muitos casos, o imóvel é

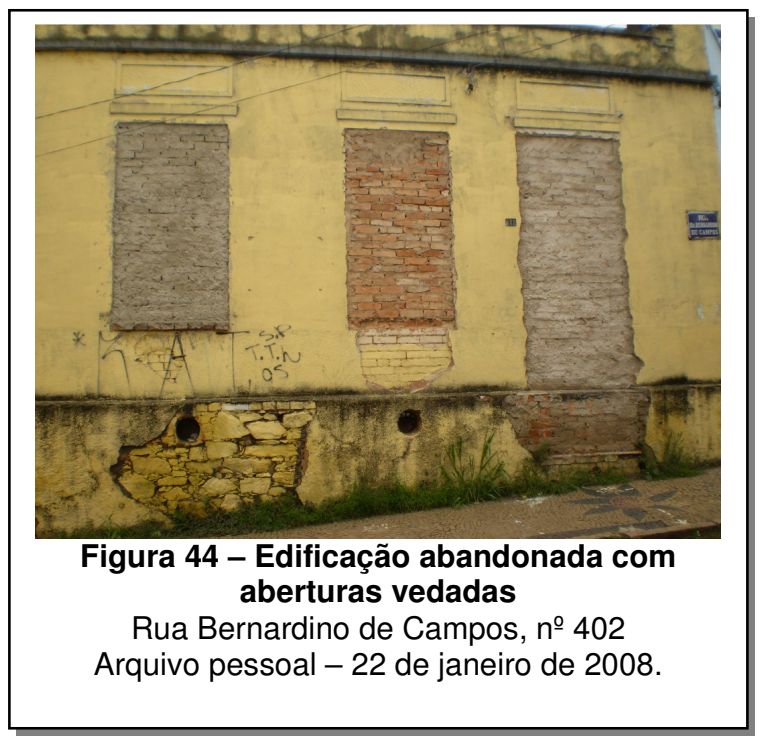
invadido e tem seu uso "camuflado", mesmo tendo as aberturas vedadas. Percebe-se o uso quando se olha para o interior do edifício através de suas eventuais esquadrias de ferro e vidro (geralmente quebrados) e nota-se a presença de roupas estendidas e alguma movimentação. Em determinados horários - que em geral coincidem com o horário de abertura e fechamento do comércio local - também pode-se observar, e aí sim confirmar, o uso dos imóveis através da entrada e saída dos moradores. Isso se dá com auxílio de escadas e passagens criadas pelos próprios ocupantes, que, quando fora do imóvel, na tentativa de adquirir alguma renda e produtos de subsistência, guardam as escadas e demais ferramentas que auxiliam a entrada e saída no imóvel invadido, em imóveis vizinhos. Encontram-se muitos imóveis funcionando sob estas condições, que se supõem ser um primeiro estágio da maioria dos imóveis invadidos que depois passam a funcionar como cortiços ou pensões sob autorização dos proprietários ${ }^{70}$.

${ }^{70} \mathrm{O}$ cortiço aqui mencionado será caracterizado no item 3.2.1. do Capítulo 3, enquanto uma das modalidades de ocupação levantadas pela pesquisa. 
Diante desta situação, alguns proprietários acabam aceitando o processo de ocupação do imóvel por parte da classe de renda mais baixa e estimulam o comércio de sublocação de cômodos ou vagas, de forma a adquirir recursos financeiros suficientes para o pagamento das dívidas adquiridas com taxas e impostos incidentes sobre o imóvel e a manutenção do mesmo. Eventualmente, ao surgir uma boa oportunidade de venda do imóvel - em geral para uma grande incorporadora - o proprietário retira os moradores do local, muitas vezes utilizando força policial.

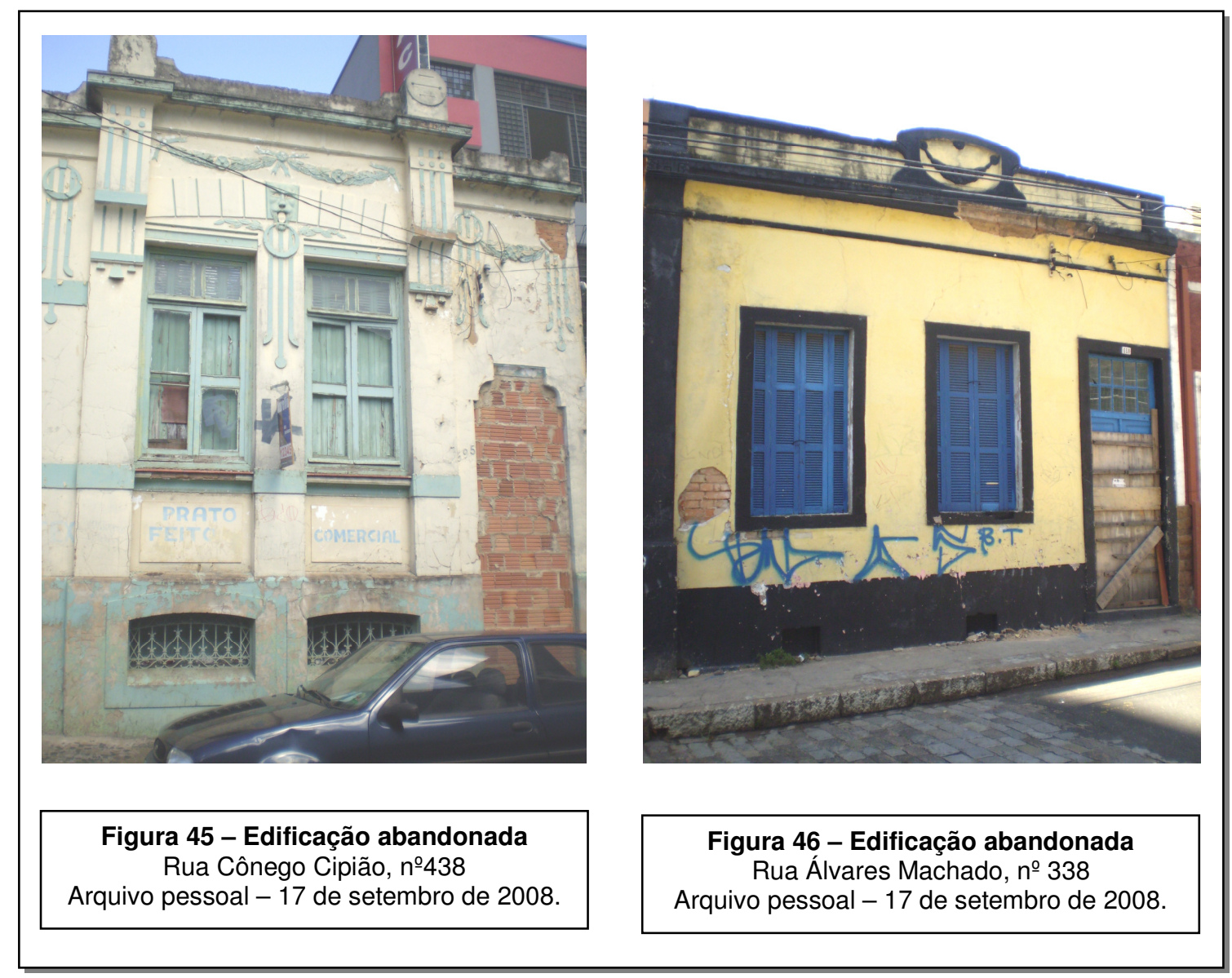




\subsection{Caracterização quanto à forma de ocupação}

Mais do que as condições físicas encontradas, são as formas de apropriação e o conjunto de relações que estas determinam, que permitem entender e caracterizar mais especificamente as habitações coletivas populares presentes na área central de Campinas. Dessa forma, revelamos uma segunda possibilidade de caracterização destas modalidades habitacionais apresentadas sob três formas principais: o cortiço, a pensão/ hotel e a invasão.

As formas de apropriação levantadas diferenciam-se por questões como: o tempo de permanência ou transitoriedade dos moradores em relação a uma unidade habitacional; presença do proprietário do imóvel habitado coletivamente ou, quando na ausência deste, a presença do administrador do "negócio"; o gênero e idade dos moradores permitidos, tendo em vista que algumas unidades não aceitam crianças, ou são exclusivamente masculinos, ou não aceitam idosos, etc; regras específicas de convívio interno relacionadas à alimentação, ao uso de tanques, banheiros, etc; "arranjos" construtivos para provimento de mais unidades a serem locadas no interior do imóvel; aspectos físicos dos cômodos; origem e ocupação dos moradores; relacionamento com o poder público.

Quando combinados, estes aspectos revelam características importantes quanto às relações estabelecidas entre os diversos atores envolvidos na questão habitacional da área central de Campinas, e como esta se insere no processo de transformação da configuração desta mesma área central.

\subsubsection{Cortiço}

As habitações coletivas populares apontadas pela pesquisa como cortiços caracterizam-se por apresentarem certas especificidades. Sua característica básica é ser uma habitação coletiva popular gerenciada por um administrador e/ou proprietário que aluga cômodos.

Em Campinas, outras características são importantes de serem destacadas, como o tempo de permanência do morador do imóvel, que em geral é de mais de 3 
(três) anos. A transitoriedade encontrada nos demais tipos a serem caracterizados não aparece como característica do cortiço.

Normalmente, são casas de um ou dois pavimentos. O nível de degradação encontrado em praticamente todas as unidades apontadas como habitações coletivas populares na área central de Campinas, aqui apresenta o seu mais alto grau. Não se percebe tentativas de manutenção ou reparos no edifício tendo acontecido nos últimos anos. Ainda assim, alguns edifícios se destacam pelas características históricoarquitetônicas. A degradação se caracteriza pelas condições do reboco do edifício (que geralmente já ruiu parcialmente deixando pedaços da alvenaria à mostra); pelas péssimas condições do forro, ausente em muitos casos, deixando assim todo o madeiramento do telhado exposto e revelando a usual presença de cupim; pela alta ocorrência de esquadrias quebradas e enferrujadas, sendo utilizados panos ou papelões na vedação das aberturas nestes casos; pela fiação elétrica exposta e deteriorada, oferecendo grandes riscos de incêndio ao edifício; pela rede hidrosanitária muitas vezes inutilizada pela idade da mesma e falta de manutenção; pelos aspectos físicos como pintura deteriorada; pelo mau cheiro e presença de animais como ratos e baratas.

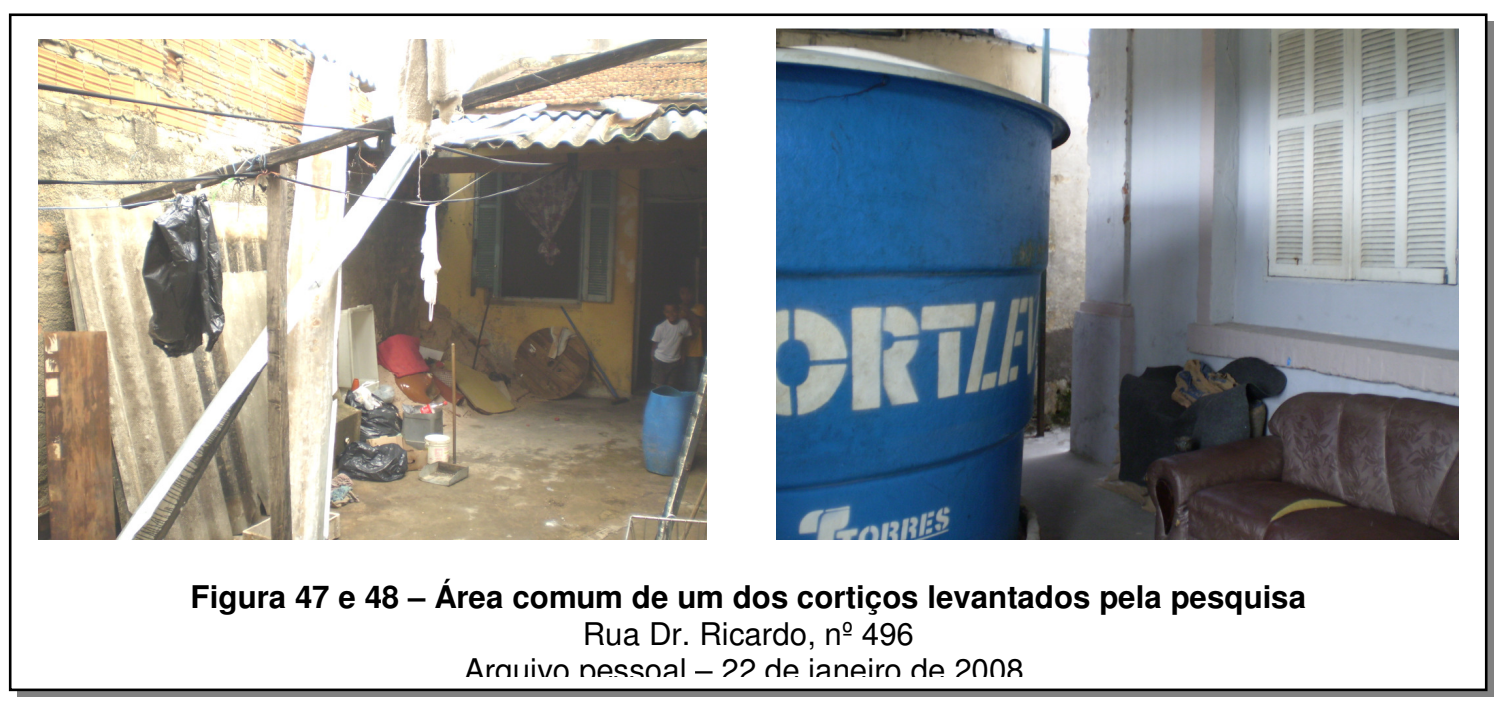

Outro aspecto importante, próprio desta forma de apropriação, é o fato de o proprietário do imóvel morar no próprio local ou em imóvel vizinho ou próximo, também de sua propriedade - em geral na mesma quadra -, de onde administra o "negócio". Enquanto o "proprietário-morador" busca, através da sublocação de cômodos ou vagas, ganhos para complementar a sua renda, o "proprietário-administrador" tem nessa atividade apenas interesses de lucros. O proprietário transforma o imóvel em 
cortiço diante das dificuldades financeiras e na impossibilidade de realizar manutenções ou reparos no imóvel e também pagar impostos e taxas que incidem sobre o mesmo. Quando morador, o proprietário divide algumas características semelhantes com os demais moradores do imóvel. Uma delas é a baixa renda mensal, provinda de atividades informais e esporádicas, relacionadas ao comércio ambulante em alguns casos, ou a atividades domésticas em outros edifícios de uso habitacional, comercial ou de prestação de serviços, além de escritórios localizados também na área central.

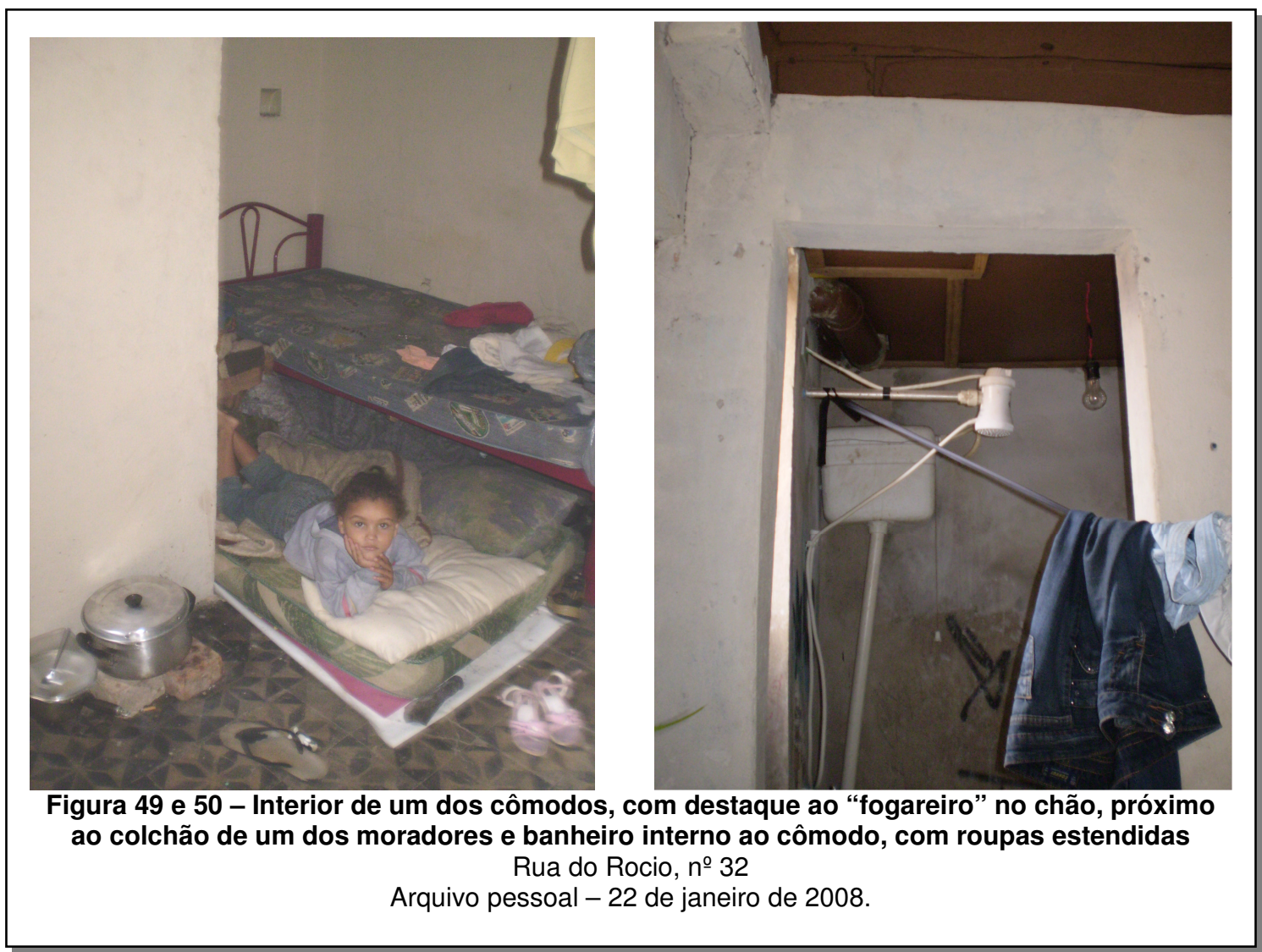

O tempo de moradia no município é outro aspecto em comum. Quando não nascidos em Campinas, geralmente já moram no município há mais de 20 anos e na área central há pelo menos 10 anos, de acordo com os depoimentos coletados. Antes de se submeterem às condições de habitabilidade do cortiço, viviam em áreas periféricas do município - em favelas, loteamentos irregulares ou conjuntos habitacionais. Quando nestes últimos, encontramos alguns moradores que venderam suas unidades informalmente para assim morarem na área central, próximos de seus locais de trabalho ou de equipamentos públicos que já utilizavam, como creches e 
escolas infantis. Apontaram os custos com transporte e o tempo de deslocamento como sendo os motivos mais fortes da mudança do local de moradia e da submissão às condições até piores de habitabilidade em relação às unidades em que viviam anteriormente.

Nestes edifícios é comum a presença de famílias inteiras - com avô, avó, pai, mãe, cunhado (a), tio (a), e muitas crianças. Estes acabam dividindo muitas vezes o mesmo cômodo, ou dois na melhor das hipóteses. Em alguns cortiços, encontramos como proprietário do imóvel uma mulher com mais de 60 anos que, nestes casos, adota a figura de "avó" das crianças e cuida das mesmas quando não estão na escola, nos horários em que os adultos da família saem para trabalhar.

Notam-se também algumas adaptações no imóvel de forma a possibilitar o aumento do número dos moradores, que chegam inclusive a ocupar os antigos porões das casas construídas na transição do século XIX e XX. Estas adaptações são feitas, na maioria das vezes pelos próprios moradores, em troca de "descontos" no valor pago por mês ao proprietário do imóvel.
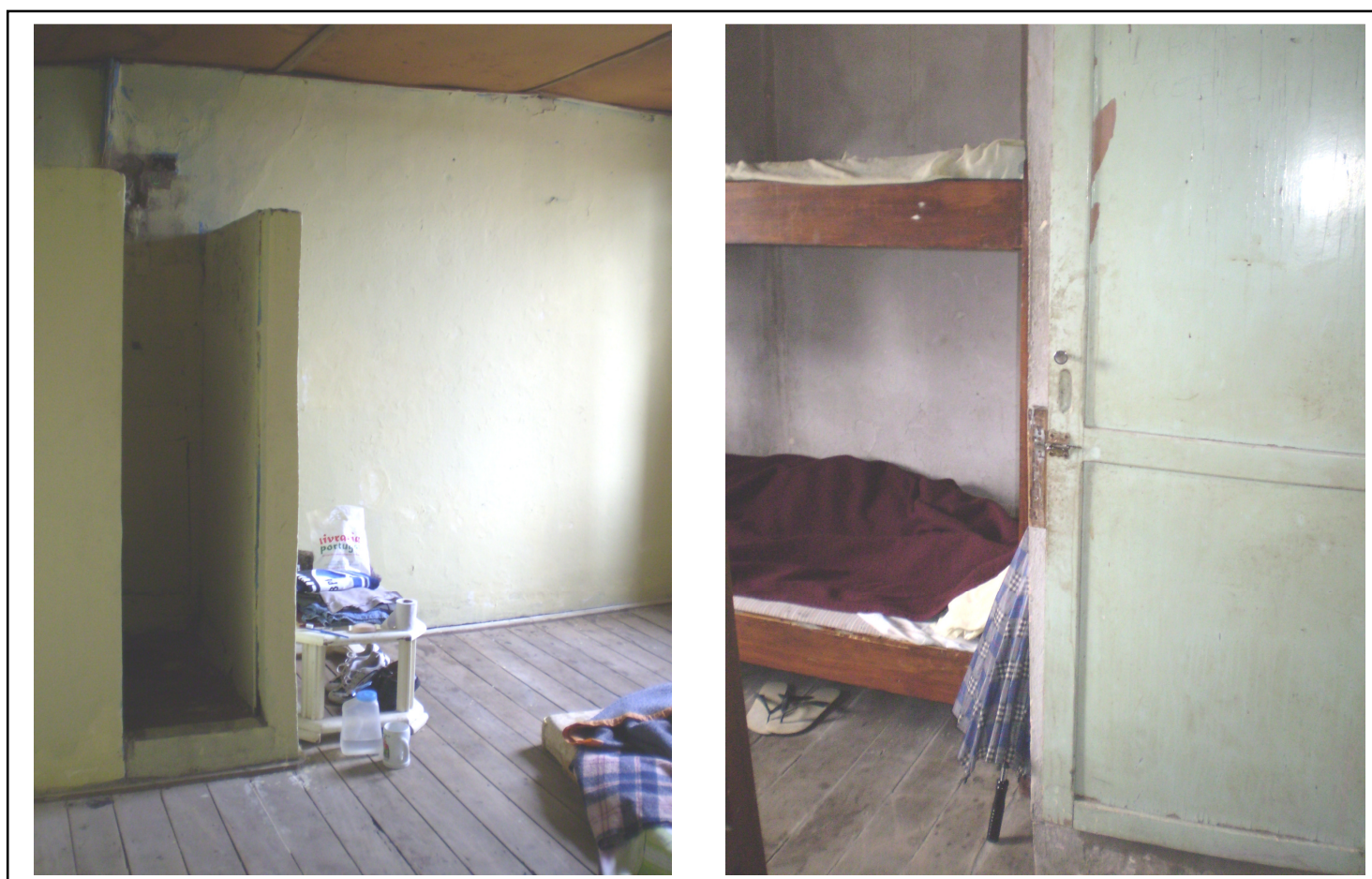

Figura 51 e 52 - Interior de um dos cômodos, com destaque à "cabine" construída, ora com alvenaria $(\mathrm{h}=2,0 \mathrm{~m})$, ora com madeirite, dentro do cômodo, contendo um vaso sanitário e um chuveiro

Rua Dr. Ricardo, no 496 
O banheiro, a pia, o tanque, os varais e o fogão, são instalados em áreas de uso comum. Dentro dos cômodos ainda é comum se encontrar panelas com comidas e "fogagueiros" executados pelos próprios moradores para esquentá-las - e isso normalmente acontece no chão do cômodo, ao lado de um colchão onde dorme uma ou mais crianças. O proprietário impõe algumas regras normalmente relacionadas ao tempo de uso destes equipamentos e algumas punições para o não cumprimento das mesmas. Mas nota-se certa conivência por parte do proprietário, e até um "espírito de solidariedade" entre os moradores do cortiço. Até pelo tempo de convivência, conseguem lidar melhor com situações de conflito, havendo bastante flexibilidade quanto a estas punições. É comum um cuidar do filho do outro, cozinhar para sua família e para outras famílias, acompanhar o filho de outro, junto com os seus próprios até a escola, etc.

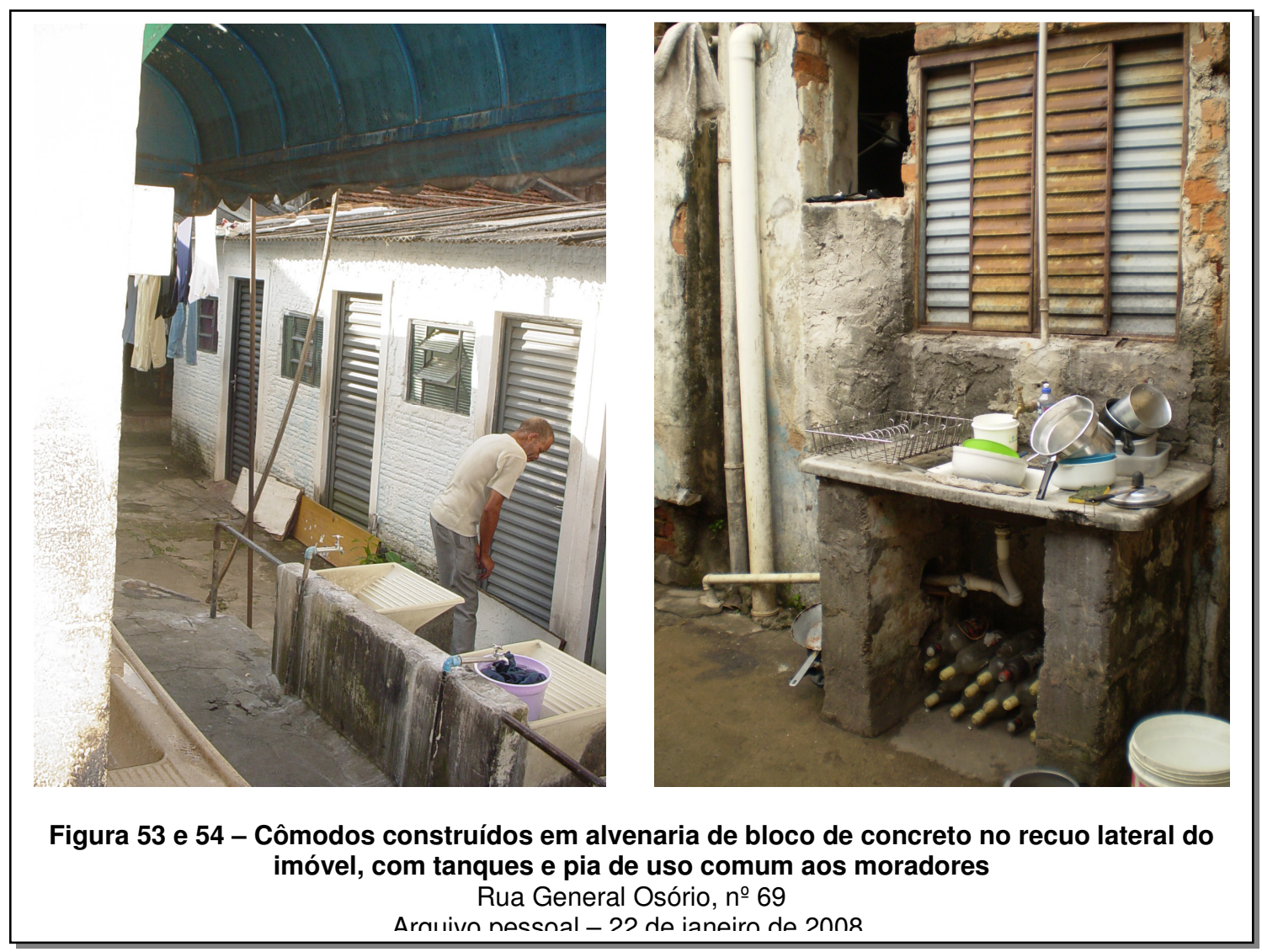

Nesta tipologia de habitação coletiva precária, não é comum encontrarmos anúncios indicativos quanto ao uso, aos valores cobrados ou algum tipo de regra estabelecida. As indicações iniciais de sua existência durante a pesquisa partiram de pessoas moradoras ou freqüentadoras da área, como guardadores de carros, por 
exemplo. Foi necessário um tempo maior de observação para depois adquirirmos informações quanto às relações estabelecidas junto aos próprios moradores, incluindo o proprietário do imóvel encortiçado.

As áreas em que esta forma de apropriação se dá em maior quantidade é na área 5 e área 6, justamente as áreas separadas do centro, propriamente dito, pelas linhas férreas. Há também presença desta forma de apropriação em quantidades consideráveis na área 2 , em locais próximos à passagem subterrânea que faz a travessia de pedestres da área em questão para a área 5 e vice-versa. Os locais se caracterizam pelo baixo tráfego de veículos automotores, pelas ruas estreitas, revestidas por paralelepípedo e pela predominância do uso habitacional.

Com relação ao poder público, este ignora a existência dos cortiços, embora durante as entrevistas realizadas junto aos técnicos da Secretaria Municipal de Planejamento e Desenvolvimento Urbano, Secretaria Municipal de Cidadania, Assistência e Inclusão Social e Secretaria Municipal de Habitação, muitos focos deste tipo de habitação tenham sido indicados, em contraposição à ausência de ações ou levantamentos sobre os mesmos. Os técnicos mais antigos, inclusive enquanto moradores do município, apontam a ocorrência de cortiços na área como um processo já consolidado, que vem se proliferando pelo menos desde a década de 1980.

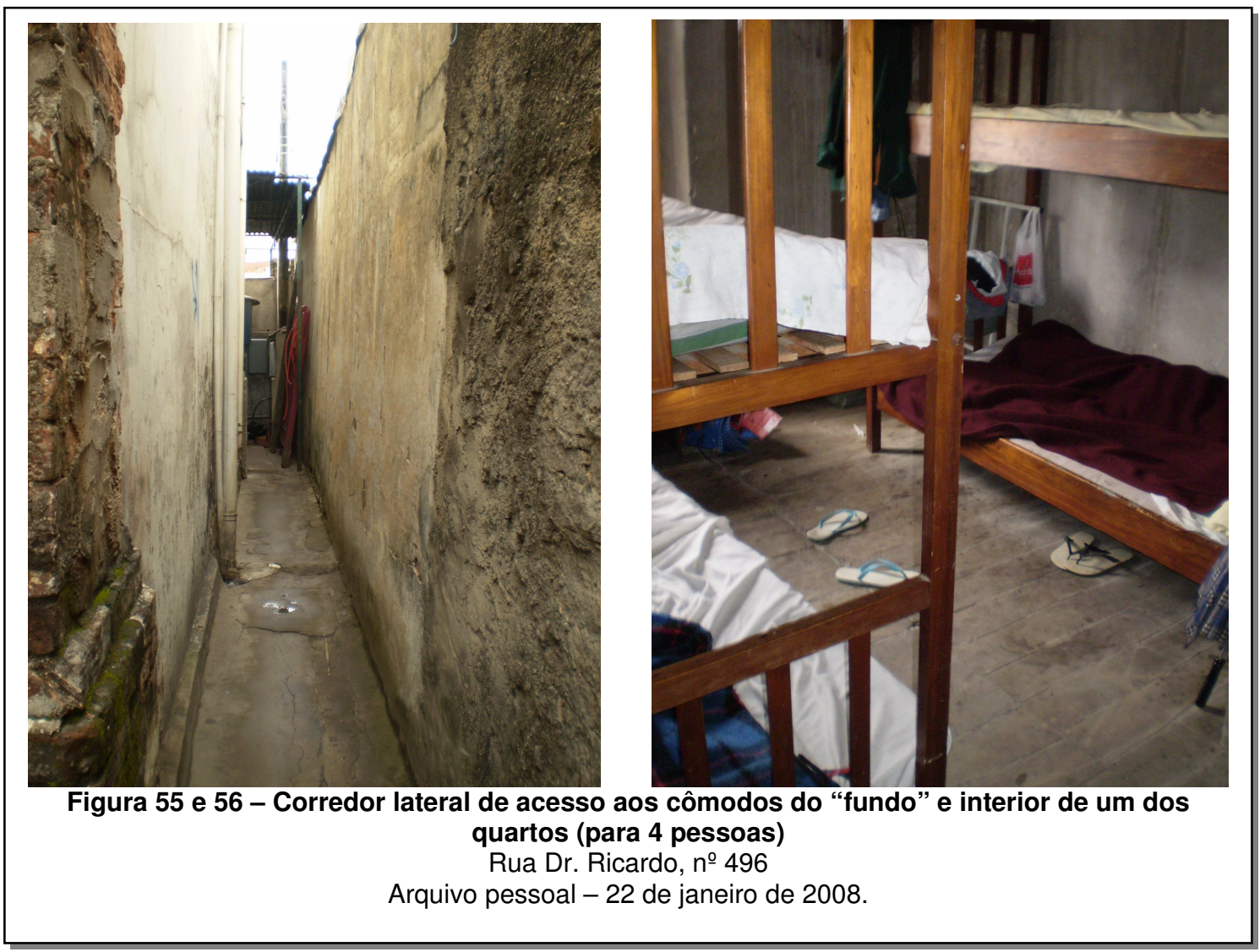




\subsubsection{Pensão ou Hotel}

Outra forma de ocupação com características diferentes, sob determinados aspectos, dos cortiços já caracterizados, aparece sob o nome de pensão ou hotel popular. Estes edifícios, onde também encontramos pessoas vivendo coletivamente e de modo precário sob determinadas regras locacionais e de convívio interno, anunciam-se através de placas ou anúncios indicativos normalmente feitos à mão livre em pedaços de papel ou papelão. Também encontramos anúncios do tipo letreiros, mais elaborados, onde percebemos que o "negócio" é mais consolidado, mais "formalizado". As placas indicativas anunciam a locação de cômodos e vagas, além de já

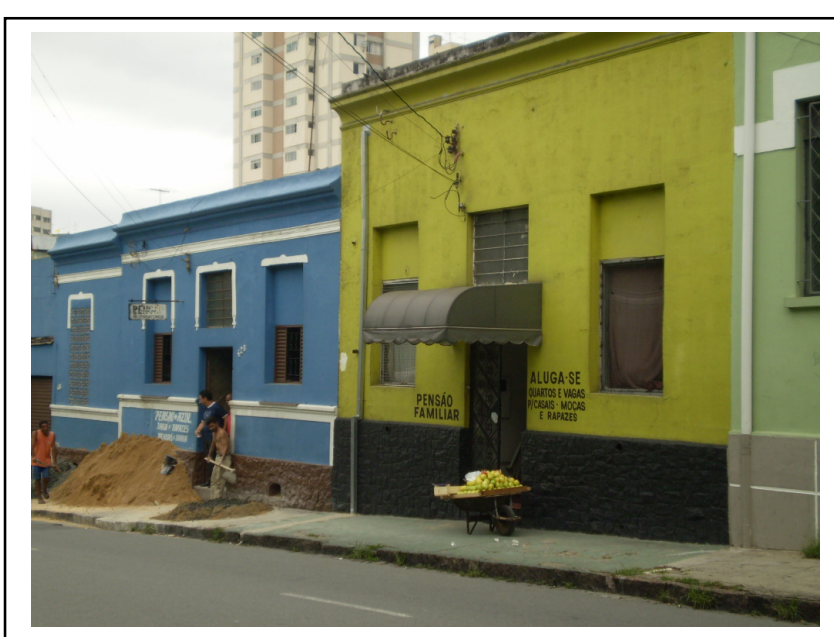

Figura 57 - "Pensão Azul” e "Pensão Familiar" (restrição de gênero)

Rua Dr. Mascarenhas, ํㅡ 428 e 238 Arquivo pessoal - 22 de janeiro de 2008.

expressarem as eventuais restrições do local, como o não aceite de crianças ou o uso exclusivo masculino.

Apesar de irregulares do ponto de vista jurídico e burocrático, pois não possuem nenhum tipo de licença ou alvará de funcionamento, o próprio poder público mantém relações oficiais - dentro da ilegalidade - com este tipo de estabelecimento a partir do momento em que os inclui em sua rede de assistencialismo. O Serviço de Atendimento ao Migrante, Itinerante e Mendicante (SAMIM), antigo "Albergue de Campinas", encaminha para estes edifícios alguns moradores de rua após adquirirem ganhos mensais através de alguma atividade normalmente manual que aprendem em algum programa público social.

As características físicas deste tipo de edifício não diferem muito do cortiço já caracterizado no sentido em que também se apresentam degradados. Porém observamos lugares menos degradados do que outros, com alguns indícios de manutenção e reparos, o que resulta numa certa categorização dos edifícios, expressa na fala de alguns moradores. 
A (pensão) do Seu Djalma é média. Boa mesmo, de primeira categoria é a (pensão) Dois Irmãos. Diferente das outras onde a gente fica que nem prisioneiro. Não pode fazer isso. Não pode fazer aquilo. Isso porque são as piores. Uma imundice só (Informação pessoal. Entrevista concedida por Sr. Pedro, morador de pensão na área central de Campinas há 5 anos, em 7 de fevereiro de 2008).

Nestes locais é mais comum encontrarmos pessoas vivendo sozinhas. São poucas as famílias que vivem em conjunto numa mesma pensão ou hotel popular, apesar de termos encontrado algumas situações em que as mesmas se faziam presentes. Isso porque, em geral, estes estabelecimentos não aceitam crianças. Entrevistamos pais de família que deixam seus filhos em determinada pensão que aceita criança e ele próprio, com sua esposa, dormem em pensão vizinha, que apesar da restrição, é

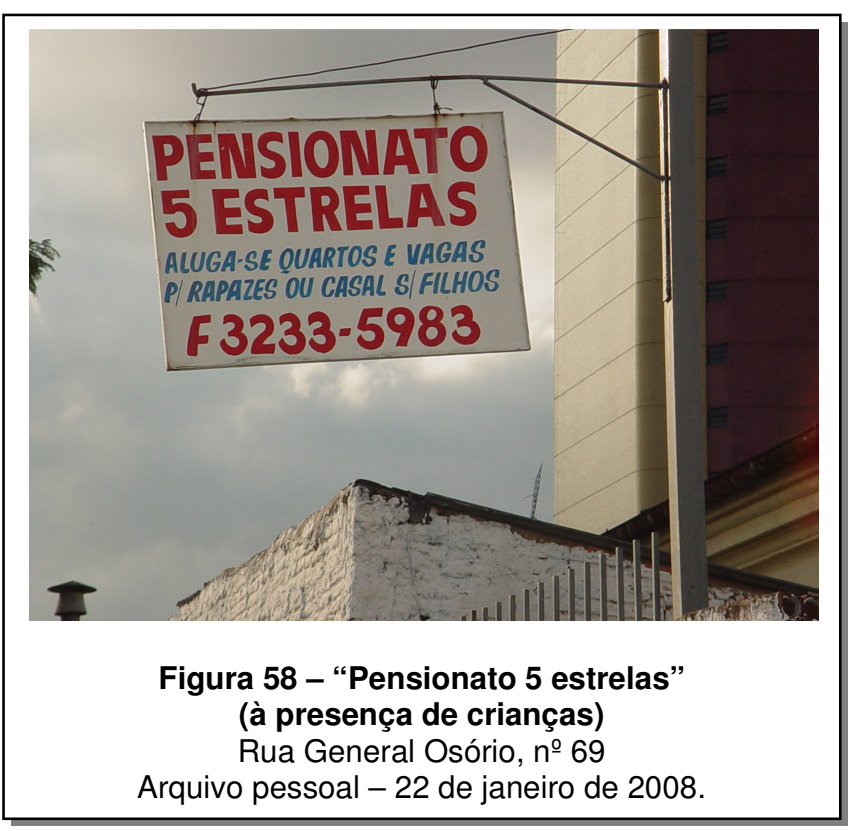
mais barata - de forma a economizar um pouco de dinheiro. Há muitos, ainda, de uso exclusivo masculino, onde vivem homens com mais de 18 anos.

Por estarem sozinhos, muitas vezes dividem o mesmo cômodo com outras pessoas desconhecidas, e, por isso, é comum o termo "locação de vagas", entendendo-se por vaga, a partir dos levantamentos executados, um colchão - no melhor dos casos - para se dormir.

Aqui aparece a figura do administrador ou intermediário, já que o proprietário normalmente se faz distante e desconhecido, e muitas vezes é até pessoa jurídica. $O$ administrador é, nestes casos, aquele que agencia e controla o "negócio", quem autoriza a entrada de um novo morador, ou expulsa outro que não cumpre com os pagamentos ou com as regras do lugar, quem recebe os aluguéis e provê as manutenções e reparos de acordo com a disponibilidade de dinheiro. É também morador, mas costuma ter um padrão de vida um pouco melhor, ocupando um 
cômodo inteiro sozinho (ou com seu companheiro/a), podendo ter inclusive um banheiro de uso exclusivo.

É o administrador quem cria e impõe as regras de convívio interno e quem cuida das penalidades - bastante duras quando do não cumprimento destas regras. De acordo com os depoimentos em diferentes estabelecimentos deste tipo, observamos que, em geral, agem

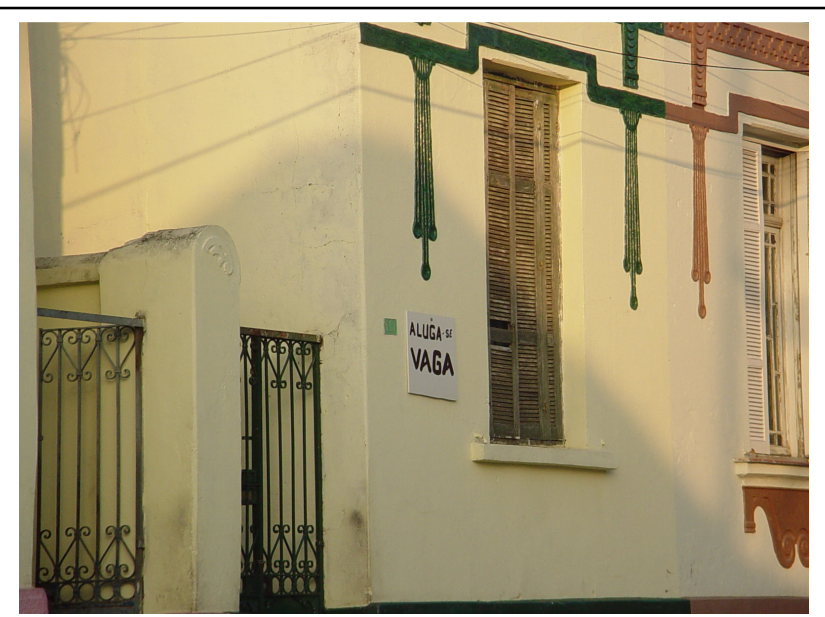

Figura 59 - Anúncio à mão livre indicando a locação de vagas

Rua Dr. Ricardo, no 504

Arquivo pessoal - 22 de janeiro de 2008. com certa agressividade em relação aos moradores, chegando a haver casos de agressão física principalmente com relação aos moradores mais idosos ${ }^{71}$.

Quase todas as pensões e hotéis populares pesquisados incluem o café-damanhã no preço cobrado na locação do cômodo ou da vaga, que se refere a pão com manteiga e um copo de café com leite, ficando o almoço e o jantar, além das demais refeições por conta de cada morador. Para tanto, dentro dos cômodos é comum se encontrar um "fogagueiro de duas bocas" ligado a um botijão de gás, panelas com restos de comida espalhados pelo chão, em cima dos colchões, etc. Para uso comum, em geral, ficam disponíveis o tanque, a pia e o banheiro.

Normalmente situam-se em casas de um ou dois pavimentos, antigas e com grande valor histórico-arquitetônico. Em alguns imóveis visitados observamos algumas adaptações construtivas importantes de serem destacadas. Uma delas é a constante presença de cômodos enfileirados, com cerca de $4 \mathrm{~m}^{2}$ cada, construídos em

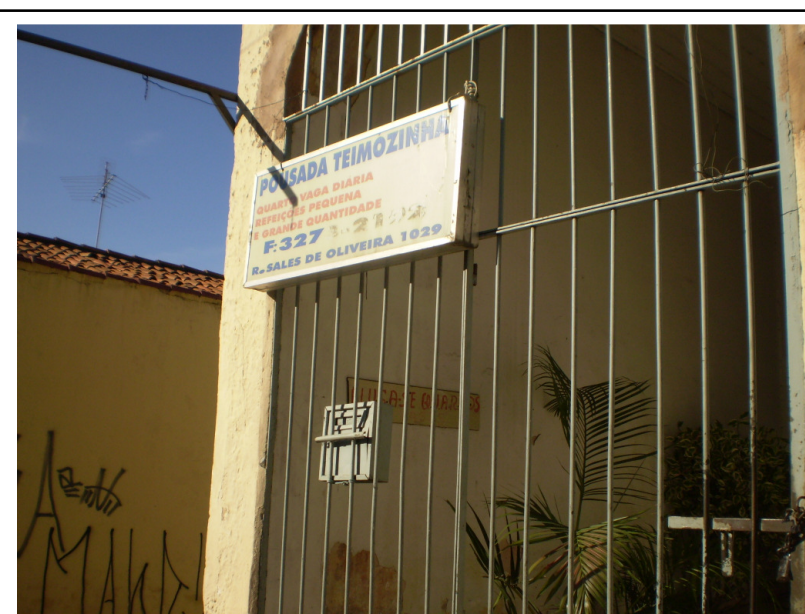

Figura 60 - Anúncios indicando a locação de vagas Rua Dr. Ricardo, no 504 Arquivo pessoal - 22 de ianeiro de 2008.

\footnotetext{
${ }^{71}$ Os conflitos vividos pelos moradores serão analisados no item 3.4., do Capítulo 3 desta pesquisa.
} 
alvenaria de bloco e telha de fibrocimento, nos antigos recuos do lote. Cada cômodo deste é ocupado por duas a quatro pessoas não necessariamente da mesma família. Outro "arranjo" que observamos é a construção de "cabines" contendo uma bacia sanitária dentro de alguns cômodos, construídas em alvenaria de tijolo ou madeirites com altura de cerca de 2,0m. Ou seja, um mesmo cômodo pode abrigar cerca de quatro pessoas convivendo entre si, com uma cabine sanitária sem abertura direta para a área externa, um fogareiro de duas bocas ligado a um botijão de gás, e um armário com roupas misturadas à sapatos e demais pertences dos moradores.

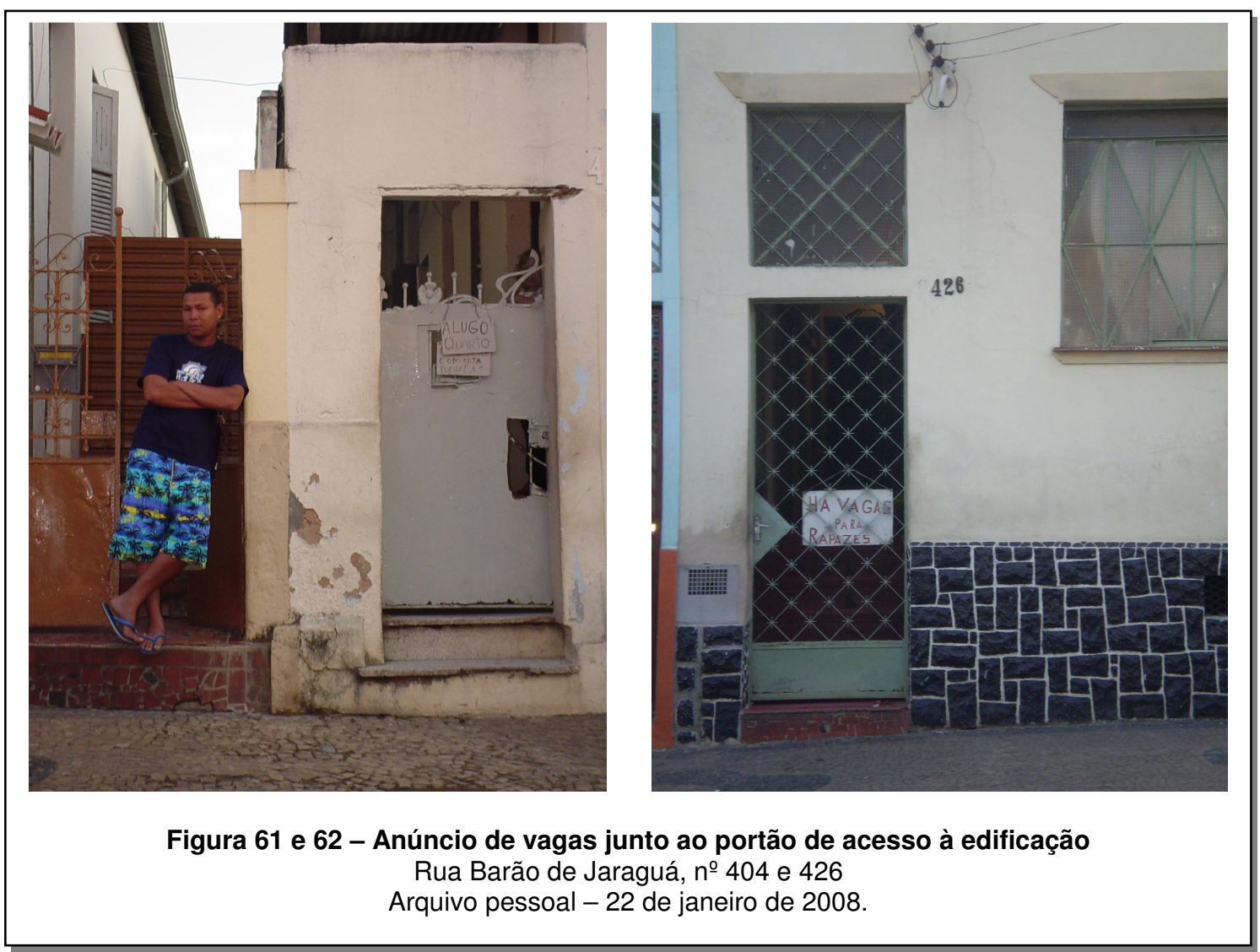

Outro fato importante de ser destacado é a transitoriedade dos moradores, que geralmente apresentam grande mobilidade entre este tipo de pensão/hotel. Dificilmente encontramos moradores que estivessem na mesma pensão ou hotel popular há mais de 1 ano, embora freqüentemente vivam em edifícios deste tipo há pelos menos 5 anos, e sempre na área central. A transitoriedade se dá quando o morador já não consegue pagar o aluguel e se vê obrigado a buscar outro local para morar, ou quando sabe de uma "promoção" em outra pensão, cujo valor mensal a ser pago é menor, ou quando o estabelecimento oferece alguma "regalia" a mais, 
normalmente relacionada à alimentação ou à higiene pessoal (entrega de sabonetes, tempo maior de uso no banheiro, etc.). Também acontece em casos de conflito, brigas com outros moradores que exercem pressão para que o primeiro procure outro lugar para morar. Por isso, entrevistar um desses moradores é saber sobre vários estabelecimentos ao mesmo tempo, pois a maioria deles já viveu em boa parte dos imóveis assim caracterizados localizados na área central de Campinas. Neste sentido, é comum encontrarmos, num espaço de cerca de 15 dias a mesma pensão lotada e depois com pouquíssimos moradores e vice-versa.

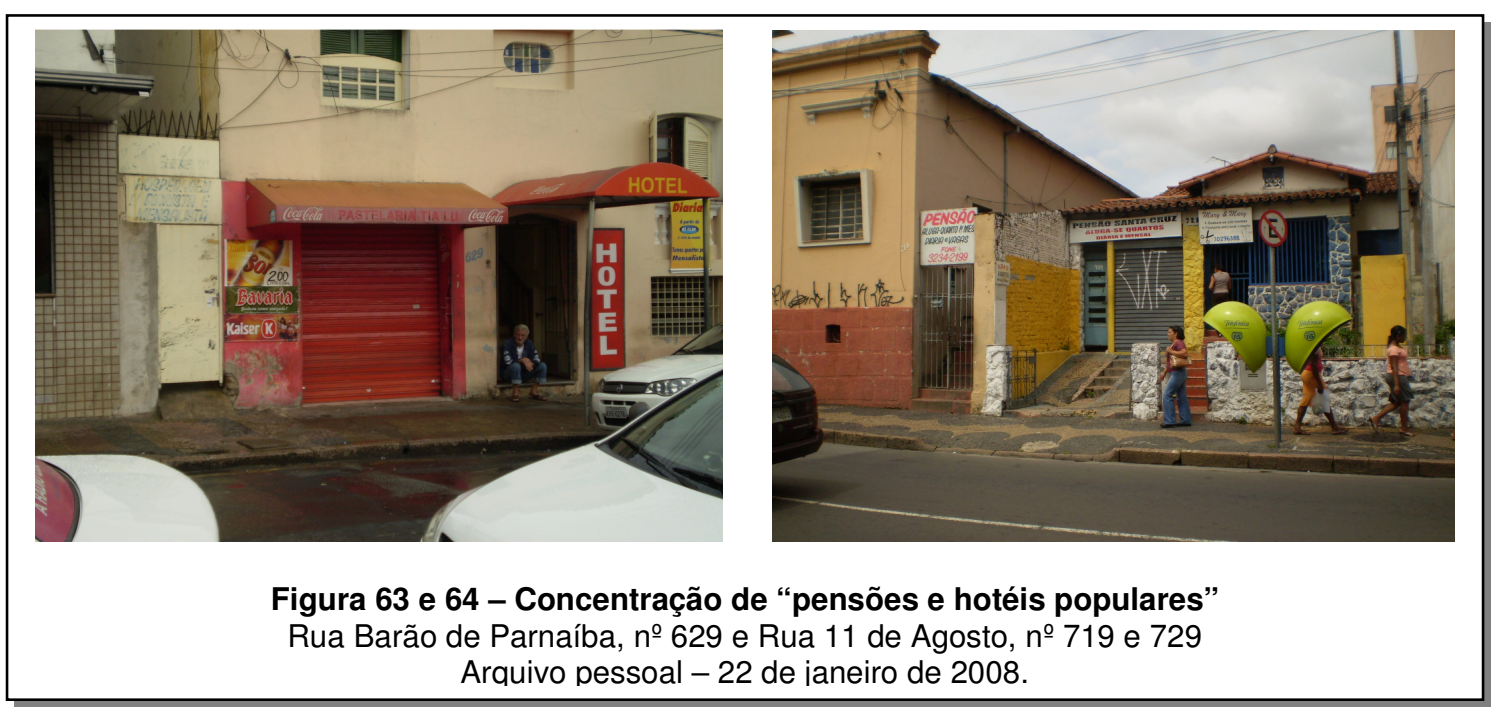

A origem dos moradores de pensão e hotéis populares também é semelhante entre si e costuma ser diferente do morador do cortiço. A pesquisa mostra que neste tipo de estabelecimento a maioria da população é migrante de outros estados brasileiros, principalmente das regiões norte e nordeste, que vêm para a região campineira em busca de empregos e outras oportunidades. Também encontramos alguns bolivianos, peruanos e colombianos vivendo como ambulantes ou em outros empregos informais. A ocupação varia entre os moradores deste tipo de habitação. Encontramos desde ambulantes ou catadores de lixo reciclável, sem escolaridade, até pessoas com $3^{\circ}$ grau completo, porém distantes de suas áreas de trabalho a algum tempo, trabalhando como porteiros, motoristas, etc., em empregos formais.

As pensões e hotéis encontram-se em sua maior parte, e inclusive formando focos ou conjuntos deste tipo de habitação coletiva precária, na Área 2, e de forma mais esparsa nas demais áreas. 


\subsubsection{Invasão}

Uma última modalidade de habitação coletiva popular levantada pela pesquisa diz respeito aos imóveis que apresentam como forma de ocupação a invasão. Nestes casos, também observamos algumas especificidades ligadas às relações internas estabelecidas.

Algumas características, quando analisadas, apresentam-se como a mescla do que fora observado e caracterizado nos cortiços, pensões e hotéis populares. Os moradores, por exemplo, em geral são migrantes das regiões norte e nordeste do país e inclusive já passaram por outras cidades do estado de São Paulo na busca por oportunidades de emprego e renda, mas também encontramos muitos moradores cuja origem é o próprio município de Campinas. Como no cortiço, também viviam em áreas periféricas e resolveram viver sob tais condições de precariedade na área central, tendo em vista as oportunidades encontradas em maior número nesta região, além da economia com tempo e custos de deslocamentos. Ainda sobre os

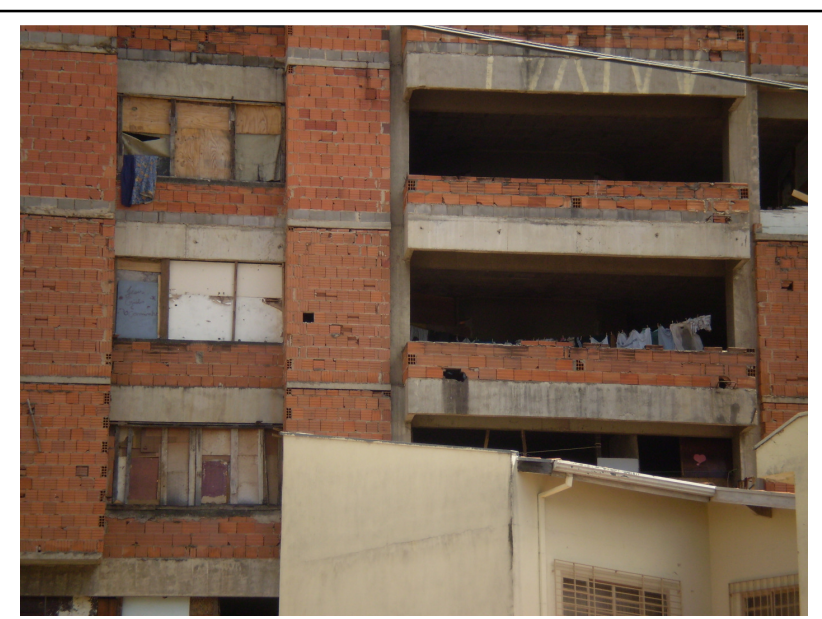

Figura 65 - Edifício inacabado invadido Rua Com. José Luiz Pereira de Queiroz, Ruas Dr. Delfino Cintra e Prof. Luiz Rosa

Arnuiven necconal - 24 de cotemhrn de 2nก8 moradores, também destacamos que se encontram nestes edifícios, pessoas vivendo sozinhas ou em família, com presença de muitas crianças. O tempo de moradia também varia. Em um dos edifícios altos invadidos encontrado, a média é de 10 anos de permanência no local. Mas também encontramos alguns casos em que a transitoriedade é maior.

Nesta forma de ocupação aparece a figura do zelador, que se aproxima ao já descrito administrador. É ele, também, quem controla a entrada e saída de moradores, tendo em vista o cumprimento de algumas regras de convivência que ele próprio cria e impõe. Normalmente, ele é o primeiro morador do local, aquele que inicia a invasão, ou que está a mais tempo morando no local. Apesar de algumas divergências entre a opinião demais moradores em relação à figura do zelador e as regras de convivência 
por ele determinadas, observamos que, em geral, predomina o respeito pelo poder a ele instituído.

Quando em imóveis de um ou dois pavimentos invadidos, observamos aquele mesmo "espírito de solidariedade" que caracteriza os cortiços, até pelo número reduzido de pessoas. Em edifícios altos ${ }^{72}$, diante do grande número de moradores, ainda que também exista a figura do zelador como organizador do local, observamos que os mesmos se organizam em grupos de relacionamento, onde internamente

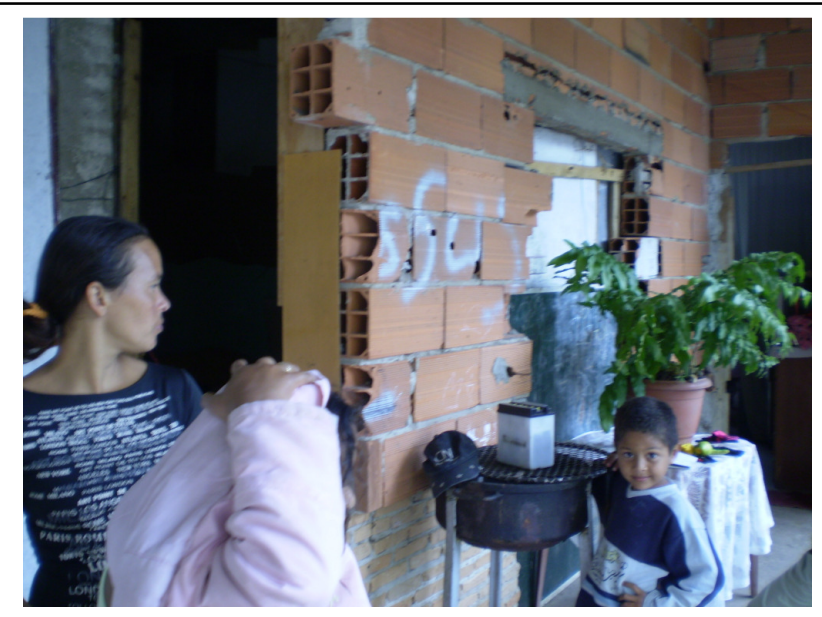

Figura 66 - "Apartamento" do pavimento térreo Rua Com. José Luiz Pereira de Queiroz, Ruas Dr. Delfino Cintra e Prof. Luiz Rosa

Arnı ıivn nessnal - 24 de setemhrn de 2008

há a ajuda mútua para a execução de atividades diárias ligadas à limpeza, alimentação e demais serviços. Entre tais grupos, o relacionamento nem sempre é tão amigável e é aí que entra a figura do zelador atuando no sentido de manter a ordem do local. Não há cobrança pelo uso dos cômodos ou vagas. Por isso mesmo o que predomina são as regras de convivência.

A ocupação dos moradores, em geral, está ligada à reciclagem de lixo. Funcionam como verdadeiras "cooperativas", inclusive com determinação de diferentes cargos: há os catadores, que percorrem a área central principalmente as áreas onde se concentram os edifícios altos residenciais - puxando carrinhos de madeira; os separadores, que

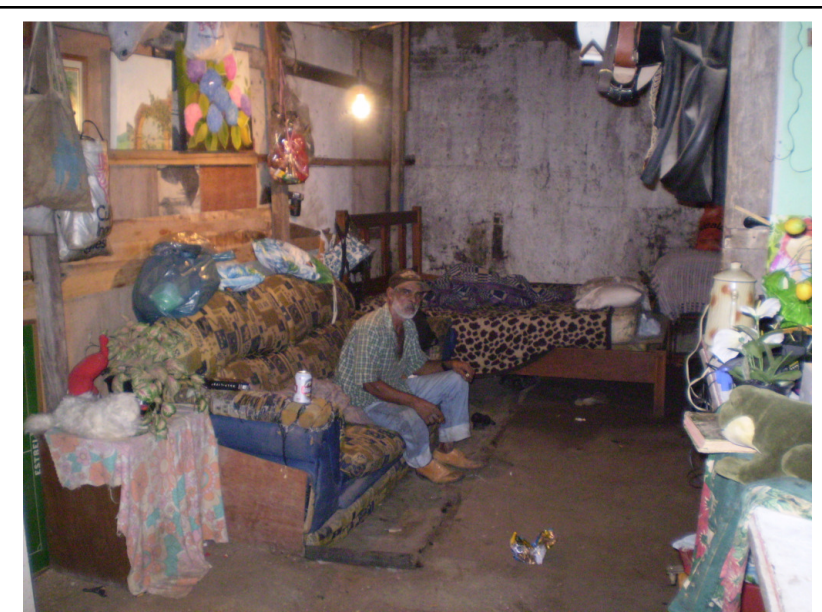

Figura 67 - Interior de um dos "apartamentos" do subsolo

Rua Com. José Luiz Pereira de Queiroz, Ruas Dr. Delfino Cintra e Prof. Luiz Rosa Arquivo pessoal - 24 de setembro de 2008

\footnotetext{
${ }^{72}$ Foram encontrados três edifícios na Área 3 de estudo com mais de 8 pavimentos, inacabados e ocupados pelo processo de invasão.
} 
fazem à triagem do lixo; os embaladores, que preparam o lixo separado para a venda; e os vendedores, que encaminham o lixo para locais de recebimento específicos. Todo este processo acontece no interior do edifício, em áreas específicas para cada etapa
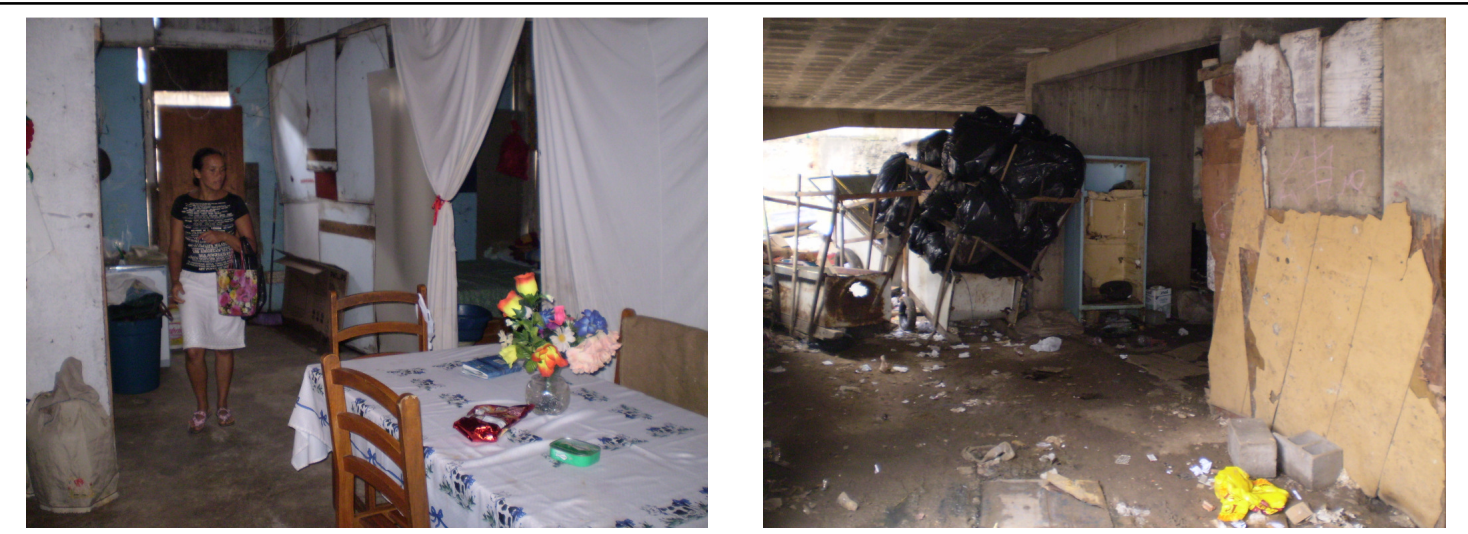

Figura 68 e 69 - Interior do "apartamento" da família do zelador, localizado no pavimento térreo e área adjacente onde se faz separação de lixo reciclável

Rua Com. José Luiz Pereira de Queiroz, Ruas Dr. Delfino Cintra e Prof. Luiz Rosa Arquivo pessoal -24 de setembro de 2008

da reciclagem.

Nestes edifícios, portanto, é comum observarmos as pessoas convivendo diretamente com o lixo e com tudo o que ele atrai, como animais e líquidos infecciosos, o mau cheiro, etc.

A tipologia própria desta forma de ocupação é, em geral, a edificação inacabada, porém também encontramos alguns edifícios abandonados, inclusive com suas aberturas vedadas por alvenaria, ocupados da mesma forma, naquilo que chamamos o primeiro estágio de ocupação para o funcionamento do cortiço ou pensão sob consentimento do proprietário do imóvel.

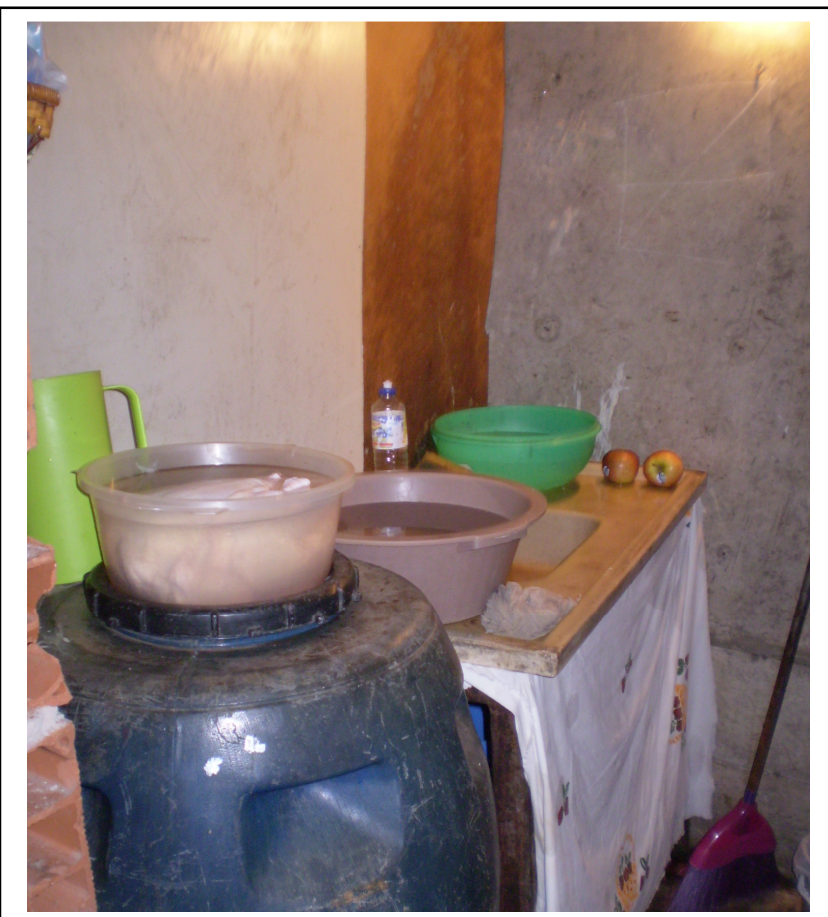

Figura 70 - Armazenagem de água

Rua Com. José Luiz Pereira de Queiroz, Ruas Dr. Delfino Cintra e Prof. Luiz Rosa

Arquivo pessoal -24 de setembro de 2008 


\subsection{Conflitos da moradia}

Durante a pesquisa de campo, foram selecionadas algumas unidades para aprofundamento das questões levantadas quanto às formas de apropriação e população residente, de forma a retratar os espaços apropriados e a dinâmica interna estabelecida.

Em cada unidade visitada procurou-se gravar os depoimentos dos atores envolvidos - moradores, administradores de pensões, proprietários dos imóveis - sem pré-agendamento ou pré-elaboração de perguntas. Entendeu-se que a análise pretendida se daria através de questionamentos quanto aos conflitos e dinâmica interna vivida por esta população, e não tanto a partir da avaliação de dados estatísticos. Tornou-se impossível prever a seqüência de acontecimentos de um dia de pesquisa de campo. Teve-se que contar com o acaso, com uma porta de cortiço que se abria, sem desconfianças ou questionamentos, outra que se fechava em sua ilegalidade e precariedade; alguém que queria falar, e então, falava por mais de três horas, outro que, de viver tão sozinho, mal dizia o próprio nome.

Os depoimentos colhidos trouxeram importantes informações que ajudaram inclusive na tentativa de caracterização das unidades encontradas. Percebeu-se que esta caracterização não se daria apenas a partir de questões físicas, construtivoarquitetônicas. Mas sim, e principalmente, a partir das relações interpessoais e das regras internas estabelecidas que se diferenciavam nas diferentes modalidades pesquisadas.

Foi assim que encontramos Elias Elliot, 57 anos, que há onze transita entre as pensões da área central. Perdeu as contas de em quantas já morou, e justifica a transitoriedade pelo preço cobrado pela vaga (procura aproveitar a melhor oferta do dia) e às dificuldades de convivência. É filósofo formado e escritor. Tem 10 livros publicados, em geral, romances e poemas que retratam a vida e as situações que tem observado em favelas e cortiços. Abandonou esposa e sete filhos no Espírito Santo em favor da "causa!" Primeiramente pertenceu ao Movimento Sem Terra e hoje diz viver "a situação que eu (ele) próprio criara". Sobrevive vendendo seus livros pelas ruas, e executando trabalhos junto a gráficas e editoras. 
Destaca o "implacável e lucrativo mercado rentista" que atua sobre a área. Conta que: "numa pensão 5 estrelas, bem ruinzinha", você vai pagar $R \$ 15,00$ por dia. Quer dizer, no mês são cerca de $R \$ 450,00 \ldots$ às vezes menos, pois você acha umas promoções." Mas diz que "é melhor do que pagar $R \$ 150,00$ por um barraco lá longe, bem longe... o cara ainda fica privado de 'viver o centro'". Sobre a vida neste tipo de habitação diz que o maior problema é a convivência.

A convivência é complicada pelo seguinte: as pessoas estão à flor-dapele, nervosas, tensas, agridem com certa facilidade. E há até um suposto código de cadeia que ronda e acompanha estes moradores. Uma palavra e você já arruma um inimigo dentro da pensão, e desse um vai para vários. [...] $\mathrm{E}$ tem aqueles que chegam cheio de sonhos $\mathrm{e}$ se deparam com pessoas más, más mesmo, quase como um violento ladrão, que te arrancam todos os sonhos, te desestimulam, te frustram, colocando dificuldades na sua cabeça... essas pessoas, que chegaram como potenciais vencedores, acabam quase que inevitavelmente como vítimas dos seus próprios sonhos. Pessoas, que estão extremamente fora da idéia de 'democracia para todos' (Informação pessoal. Entrevista concedida por Elias Elliot em 23 de janeiro de 2008).

Ainda sobre este tipo de habitação, declara que "existem locais onde o sol não atinge", famílias com crianças, sem crianças, pessoas sozinhas ${ }^{74}$ habitando um mesmo quarto e, em muitos casos, habitando os porões das antigas casas burguesas, como é o caso da pensão "2 irmãos" que loca vagas neste tipo de espaço. Sobre a cidade e a relação que tais moradores, em geral, migrantes de outras regiões do país, estabelecem com a mesma, destaca:

São pessoas que vem de fora e chegam sempre com algum tipo de dificuldade pra resolver. Aliás, eles fogem das dificuldades nas suas cidades-natal pra tentar resolver aqui, mas logo eles percebem que a realidade é outra... Já senti os golpes da cidade. A cidade é inclemente. A cidade é fria, objetiva você tem que ter o que ela quer senão... Chega gente com todas as histórias, outros chegam pela situação, pela causa. No meu caso foi pela causa, senti que aqui era

\footnotetext{
${ }^{73}$ Elias Elliot, bem como outros moradores, contam que existe uma classificação dada às "pensões" pelos próprios moradores da área central: "Pensão 1 estrela", seria a melhor, enquanto que, numa escala decrescente, "Pensão 5 estrelas" seria a pior.

${ }^{74}$ As restrições destes tipos de edificações já foram colocadas no item anterior, e em geral, referem-se à presença de crianças ou a questões ligadas ao gênero e idade dos moradores.
} 
uma cidade que poderia representar alguma coisa boa, dada a quantidade de universidades, o próprio parque tecnológico, metrópole, né?! (idem).

Quanto aos moradores e seus principais conflitos pessoais diários, diz:

Rola tudo: droga, tráfico, pessoas perigosas que estão de passagem pela cidade... o que você quiser criar de situação esdrúxula tem... cabe!!! Não é ficção pura e simples. Existe!!! Também têm outros que não perdem a dignidade, se vestem bem, tomam seus banhos, mas quando a noite cai vão para seus abrigos, para as pensões, para os cortiços... (ibidem).

Maria Damiano, 35 anos, mãe de três filhas com idades de 5 a 10 anos, é moradora de um dos edifícios altos inacabados por meio de invasão há 10 anos ${ }^{75}$, após, vindo da Bahia, ter se deparado com o desemprego e suas conseqüências. Com seu marido João, 47 anos, e seus cunhados, desenvolve trabalho de reciclagem de lixo dos condomínios verticais vizinhos ao prédio invadido. O lixo recolhido é armazenado e separado junto ao próprio lugar de moradia. Suas filhas freqüentam escola e creche da rede pública existentes na área central, de onde provêm roupas e brinquedos doados. A família também obtém uma cesta básica por mês junto à Paróquia próxima. A renda mensal familiar é de $\mathrm{R} \$ 80,00$, provenientes exclusivamente do trabalho com reciclagem, e mais $R \$ 80,00$ do programa federal Bolsa Família.

Sua família, juntamente a outras famílias moradoras do pavimento térreo e subsolo, formam um grupo de relacionamento organizado pelo trabalho com a reciclagem. Com relação aos demais grupos existentes no local, organizados conforme o pavimento de moradia, diz que sempre há briga, principalmente por causa dos filhos:

Outro dia fiz até um BO (boletim de ocorrência)... Uma mulher aí de cima que me agrediu. Eu falei prá ela que não tenho culpa das minhas filhas ganharem roupas do pessoal da igreja e da creche. É tudo doação. E elas precisam, não vou negar (Informação pessoal. Entrevista concedida por Maria Damiano em 24 de janeiro de 2008).

\footnotetext{
${ }^{75}$ O edifício alto inacabado em questão localiza-se na Área 3, na Rua Com. Luiz José Pereira de Queiroz, entre as Ruas Dr. Delfino Cintra e Professor Luiz Rosa.
} 
Também comenta sobre o relacionamento com a área de entorno que se destaca pela concentração de condomínios verticais:

Quando a gente faz festa eles (moradores dos outros prédios) chamam a polícia, mas graças a Deus, este ano ainda não teve problema. Por enquanto... [...] Tentar já tentaram (retirá-los do local)... abaixo-assinado, mas não foi todo mundo que concordou, por causa das crianças. Tem muita criança. Criança tem bastante. Tem lá em cima, tem bebê, tem criança pequena... (idem)

Com relação à moradia se diz satisfeita, assim como outros moradores do mesmo edifício também entrevistados, mesmo diante das condições de precariedade encontradas. Como justificativa coloca as facilidades de deslocamento tanto para execução do trabalho de reciclagem, tendo em vista que a origem do lixo coletado são os condomínios verticais vizinhos, como para outras atividades como levar as filhas na creche e escola, ou a utilização de outros equipamentos públicos. Além disso, destaca outros aspectos:

Não vou dizer que eu não sinto saudade da minha terra. Sinto. Só que lá não tem emprego e não tem o que tem aqui em Campinas. $\mathrm{E}$ aqui é centro. Tem emprego. Eu sei quantas famílias eu ajudo a sustentar com a reciclagem que pego aqui nos prédios vizinhos. Por exemplo, o dono do ferro velho depende da gente, se a gente não levar material pra ele comprar, como é que ele vai fazer?! (ibidem)

Outras quinze famílias - cerca de setenta pessoas - habitam do primeiro ao terceiro andar do prédio invadido, sob autorização de João, que acabou ficando com a função de zeladoria e coordenação por estar a mais tempo residindo no local. As unidades habitacionais são produzidas e compartimentadas com madeirites, papelões e panos. Não contam com rede de água - que é trazida e armazenada em baldes a partir de um ponto de água localizado na praça em quadra vizinha - para preparação de alimentos, banhos e limpeza geral. Também não há rede de esgoto, sendo os dejetos armazenados ao longo do dia e despejados em "local específico" à noite. $\mathrm{O}$ "apartamento" de Maria e João conta com mais de quatro cômodos, sendo um mais reservado, destinado para uso como banheiro. Os demais "apartamentos" são 
compostos por dois ou três cômodos e seus moradores fazem uso de banheiro - ou local reservado - de forma coletiva. Não há janelas nos cômodos, somente abertura de entrada e saída. As crianças, que existem em grande quantidade, brincam em meio ao lixo e à falta de segurança, já que o prédio é inacabado e apresenta ferragens enferrujadas e expostas, ausência de peitoris nos andares, etc.

Dona Tonha, 55 anos, administradora de pensão, conta que ela e seu marido, falecido há cinco anos, ocuparam a casa que se encontrava, na época (1985), abandonada e lá montaram seu "negócio"76. Logo após terem invadido o imóvel, enfrentaram vários embates com seus proprietários, até conseguirem chegar a um acordo. Desde então, com o consentimento dos proprietários da casa, arca com todas as despesas do imóvel e sonha em conseguir, através da lei de usucapião, a propriedade da casa.

Eu e meu marido estamos na casa há 20 anos (desde 1985). Ela estava abandonada e então nós ocupamos e resolvemos montar nosso negócio aqui [...] nós pagamos todos os impostos da casa e meu falecido marido até fez umas melhorias [...] cada quarto tem seu banheiro. A 'dona' que falou pra gente fazer, que ia dar mais lucro. (Informação pessoal. Entrevista concedida por Dona Tonha em 27 de janeiro de 2008).

Os proprietários atuais dizem estar esperando o terreno valorizar, e enquanto isso, 'cedem' a casa há vinte e três anos para que Dona Tonha e outros tenham onde morar. Neste caso em específico, não há repasse de percentual dos rendimentos obtidos com a locação de vagas e cômodos para a proprietária, mas Dona Tonha é responsável pelo pagamento de todas as taxas e impostos incidentes sobre o imóvel. Destacamos também, a dificuldade em se falar com os proprietários destes tipos de edificação, quando estes não são moradores e "gerem seus negócios" através de administradores ou intermediários.

Estamos esperando o terreno valorizar. Enquanto isso, podemos ajudar os mais necessitados, cedendo a casa para aqueles que não tem onde morar (Informação pessoal. Entrevista concedida, por telefone, por Cláudia, advogada, proprietária do imóvel, em 27 de janeiro de 2008)

\footnotetext{
${ }^{76}$ O imóvel em questão localiza-se na Área 2, na Rua General Osório, ㄲo79.
} 
Neste imóvel, a pesquisa identificou alto grau de deterioração, e inúmeros problemas de ordem estrutural. São sete quartos, onde habitam vinte e oito pessoas, sendo dois quartos - os que não possuem janelas - habitados por duas famílias com filhos pequenos, que ficam sob cuidados de Dona Tonha enquanto os pais realizam trabalhos com reciclagem de lixo durante o dia. Todos os quartos possuem uma bacia sanitária separada por madeirite ou alvenaria com altura de 2,0m aproximadamente, assemelhando-se a uma cabine. Pia, tanque e chuveiro de água fria ficam na área externa e são de uso comum.

Em outro imóvel ${ }^{77}$, apontado pela pesquisa como cortiço dada suas características, encontramos outras situações que expressam as dificuldades vividas pelos moradores destes tipos habitacionais. Além das más condições físicas, o dia-adia dos moradores é tenso devido à convivência forçada entre as famílias e à violência imposta pelos proprietários ou administradores/intermediários, como podemos constatar pelos depoimentos:

Todo dia tem discussão na fila do banheiro, sempre nas horas antes de se sair para o trabalho (Informação pessoal. Entrevista concedida por Sr. Arnaldo em 07 de fevereiro de 2008).

O proprietário mora no quarto da frente e ele tem o controle da luz. Qualquer barulho, um pouquinho que a gente faça, algazarra de criança, rádio, conversa, ele corta a luz e a gente fica uns dois dias aqui na maior penúria (Informação pessoal. Entrevista concedida por Djanira em 07 de fevereiro de 2008).

Temos apenas cinco minutos para usar o banheiro por dia. Outro dia um senhorzinho lá demorou um minuto a mais. Agora tem que ficar cinco dias sem usar o banheiro (Informação pessoal. Entrevista concedida por Elaine em 07 de fevereiro de 2008).

\footnotetext{
77 O imóvel em questão localiza-se na Área 5, na Rua Alferes Raimundo.
} 
Sobre a submissão às condições precárias de habitação encontradas, os depoimentos revelaram as expectativas de alguns moradores em voltar para suas cidades-natal.

meu marido trabalha em um restaurante aqui no centro como cozinheiro. Não vale a pena ter casa porque um dia, quem sabe, podemos voltar para o Piauí (Informação pessoal. Entrevista concedida por Dona Maria José em 10 de março de 2008).

Nem todos têm escolaridade baixa, estão ali por uma necessidade maior. Às vezes mora naquelas condições, e têm 15, 20 mil reais numa caderneta de poupança, e continua poupando para um dia quem sabe voltar para sua terra. Mas outros não agüentam a pressão consumista, as propagandas... A maioria... O consumismo fala mais alto (Informação pessoal. Entrevista concedida por Sr. Natalino em 10 de março de 2008).

Porém, a maioria da população encortiçada mora e deseja continuar morando nos bairros centrais da cidade devido à proximidade do trabalho, à facilidade de transporte, à existência de infra-estrutura como luz, água, coleta de lixo e esgoto e de recursos sociais como escolas e hospitais públicos, como foi constatado nesta pesquisa, o que não significa que todos estejam usufruindo desses serviços. Além disso, declararam que a oportunidade de empregos é maior. Esse conjunto de fatores justifica a satisfação da maioria perante sua moradia.

\subsection{Ações recentes}

Foram observadas algumas tentativas - ou indícios de tentativas - no sentido de inserir Campinas no debate acerca das condições de habitabilidade em cortiços e habitações coletivas precárias localizados em áreas centrais.

Um diagnóstico elaborado, em 1993, pela Secretaria de Planejamento e Meio Ambiente (SEPLAMA) para implantação do Programa de Revitalização do Centro de Campinas, aprovado em lei no ano de 1995, levantou unidades encortiçadas, em meio 
a dados relativos a uso e ocupação do solo, em sete áreas delimitadas para estudo ${ }^{78}$. Porém, não se tem no escopo do trabalho os parâmetros utilizados para a detecção das unidades apontadas como encortiçadas. Além disso, o diagnóstico e as proposições finais não consideraram tais dados, focando suas propostas em ações gerais de manutenção física e estímulo comercial, cultural e de lazer, não abarcando a questão habitacional.

Em 2001, a COHAB-Campinas iniciou uma pesquisa, na tentativa de participar do Programa de Arrendamento Residencial (PAR), do governo federal. Porém, concentrou seus esforços no levantamento de áreas disponíveis para a implantação de novas unidades, não se interessando pela linha de reforma e reabilitação de unidades existentes em situação de precariedade. Para tanto, buscou uma parceria com a Coordenadoria Setorial do Patrimônio Cultural (CSPC), que executou, inclusive, projetos para as Vilas Manoel Dias e Manoel Freire, patrimônios históricos tombados, localizadas na Vila Industrial (Área 5), aliando a reabilitação de tais edifícios à preservação do patrimônio histórico, já que as mesmas encontravam-se, naquele momento, em situação de deterioração. Porém, não foi dada continuidade à iniciativa.

Na mesma época, instituiu-se a Zeladoria do Centro, 'braço' do SEPLAMA, que visava propostas de melhorias para área central. Esta, entretanto, também não abrangeu a problemática habitacional, porém voltou suas ações à classe de renda baixa, com projetos como a construção do Centro Popular de Compras, a Reurbanização da Rua 13 de Maio (calçadão de comércio popular), a implantação do Centro Profissionalizante de Campinas (CEPROCAMP) junto ao prédio da antiga Estação Ferroviária Paulista, a instituição da Associação Amigos do Centro e o Projeto Rua Minha, entre outras ações, o que reforçou a tendência já verificada de apropriação da área central, dita "abandonada", pela classe popular.

Outro fato importante foi a tentativa da CDHU, através do Programa de Atuação em Cortiços (PAC), de incorporar a cidade de Campinas, em sua primeira fase de atuação. Reportagem do Correio Popular ${ }^{79}$ apontava um levantamento que seria realizado para identificar os cortiços na área central. Porém, em entrevista concedida em setembro de 2007, a gerência do PAC informou que o município, que deveria disponibilizar equipe para tal levantamento, não forneceu o relatório com

\footnotetext{
78 Diagnóstico/ Estudo Preliminar para implantação do Programa de Revitalização do Centro. Campinas: DEPLAN/ SEPLAMA, 1993, mapa 3.

${ }^{79}$ LIMA, Raquel. CDHU Campinas vai mapear cortiços da cidade. Correio Popular, Campinas, 03 de novembro, 2002.
} 
diagnóstico acerca da questão e, por isso, o PAC voltou suas ações apenas para os municípios de São Paulo e Santos.

A relação entre a área e o Serviço de Atendimento ao Migrante, Itinerante e Mendicante (SAMIM), antigo "Albergue de Campinas", é outra questão de relevância. Trata-se de uma instituição pública, fundada em 1987, e atualmente vinculada à Secretaria Municipal de Cidadania, Assistência e Inclusão Social, que presta serviço aos indivíduos em "situação de rua" em Campinas. Localiza-se no Bairro Bonfim, próximo ao centro da cidade, e atualmente tem como ação principal o atendimento aos que denominam "Migrante, Itinerante e Mendicante". O serviço declara ter como função básica a recepção, a triagem e o encaminhamento à cidade de origem ou a outros tipos de atendimentos da cidade. Em dezembro de 2006, o Serviço de Acolhimento e Refenciamento Social (SARES), outro órgão de atendimento ligado à mesma Secretaria, apontou como resultado de 2005, um atendimento de 850 moradores de rua, quase metade (48\%) entre 18 e 39 anos de idade, dos quais $85 \%$ eram homens e $67 \%$ solteiros, com destaque à quantidade de dependentes químicos (65\%) e com "transtornos mentais" (35\%).

Mesmo negando oficialmente a existência dos cortiços e pensões, a própria Secretaria nos encaminhou uma lista de pensões localizadas na área central ${ }^{80}$, com endereço, telefone e nome de contato, como sendo os locais para onde tais indivíduos em situação de rua seriam encaminhados após estarem "incluídos socialmente", com ganhos mensais provenientes de alguma atividade estimulada por programas públicos municipais. Os nomes de contato, constante na lista, apresentaram-se como administradores dos locais. Não informaram o nome dos proprietários, mas nos deixaram adentrar os imóveis, o que foi suficiente para enquadrá-los como habitações coletivas populares precárias.

Outro ponto a ser destacado refere-se à $1^{\text {a }}$ Conferência Municipal de Habitação, realizada em 2002, que marcou a formalização de uma política habitacional para o município, num processo que contou com a participação popular, através dos movimentos populares e representantes em conselhos populares. Definiu três frentes principais: "a regularização do existente ${ }^{81}$, a produção de novos bairros e moradias e meios de viabilização das ações, com um sistema permanente de participação popular

\footnotetext{
${ }^{80}$ Mensagem recebida por cmcarq@hotmail.com em 18 de setembro de 2007.

${ }^{81}$ A resolução classifica nesta frente às favelas, ocupações organizadas, ocupações em terrenos públicos municipais, loteamentos irregulares, conjuntos habitacionais públicos sem registro ou em situação irregular. (Prefeitura Municipal de Campinas: 2002, p.8).
} 
nas decisões e contrapartida organizativa da administração ${ }^{82}$ " Esta política é reafirmada pela $2^{\text {a }}$ Conferência realizada no ano seguinte, e direciona os trabalhos da Secretaria Municipal de Habitação atualmente, os quais não voltam seus olhos para a problemática da habitação na área central da cidade.

Vale ressaltar que, em pesquisa realizada junto à Secretaria de Planejamento e Meio Ambiente (SEPLAMA), Setor de Cadastro Imobiliário e Setor de Aprovação de Projetos, observamos que boa parte das adaptações construtivas ou transferência de uso habitacional unifamiliar para o uso habitacional coletivo, não passam por processo de aprovação ou regularização junto à prefeitura. Também não há indícios de fiscalização que atuem no sentido de verificar a área mínima dos cômodos, área de ventilação e iluminação mínimas, largura de corredores, número de conjuntos sanitários, e outros aspectos ligados à construção ou à condição física dos imóveis, etc. A fiscalização também não passa pela existência ou não de alvará ou licença de funcionamento e outros documentos relacionados à ao uso atual destas edificações, nem quando as mesmas se anunciam "pensões" ou "hotéis" através de placas indicativas. Quando questionados sobre a existência de legislação que coíba o cortiço como alternativa habitacional, funcionários das secretarias e setores municipais citados disseram não saber se havia algo em específico, reforçando a idéia de negação quanto à existência de habitação coletiva popular na área central de Campinas. Diante deste quadro, o pesquisador Ari V. Fernandes destaca que:

Cortiço sempre foi um estigma, há uma visão mais elitista da cidade que, assim como negou durante anos as favelas, negam os cortiços. O pessoal fala em pensões, até porque há uma legislação que coíbe e pode impor até multas muito graves ao proprietário do imóvel, se este for caracterizado como cortiço. Por isso, quando se fala em começar um levantamento criterioso, sistematizado, na área central, já se mobilizam alguns setores, aparece gente na Prefeitura, tentando acabar com isso. Isso porque o proprietário, o topo mais alto da pirâmide, já é uma pessoa jurídica, uma imobiliária da cidade ou até de fora dela, que vai comprando lote a lote, por fim o quarteirão, sabendo que outra concorrente também já está comprando outro quarteirão, até que um dia consigam fazer uma unificação dos lotes, unir-se a um incorporador e assim associar-se para levantar um prédio, um empreendimento, dificilmente residencial. [...] São (as incorporadoras), de forma explícita promotoras de uma degradação

\footnotetext{
${ }^{82}$ Resoluções da $1^{\text {a }}$ Conferência Municipal de Habitação. Campinas: 2002, p. 5.
} 
urbana. Os incorporadores buscam as imobiliárias, que nunca revelam seu cartel, falam de quantos metros precisam, e aí há todo o jogo de compra de lotes, unificações, etc. (Informação pessoal. Entrevista concedida pelo Prof. Dr. Ari Vicente Fernandes em 22 de janeiro de 2008).

Enquanto isso, dissemina-se a idéia de que a área central está abandonada, degradada em contínuo processo de esvaziamento, e que a solução estaria na "revitalização" ou "reestruturação" da mesma pautada em ações de embelezamento e alterações viárias. Ainda segundo o pesquisador,

Ninguém quer mexer pelo preconceito social, seja pela negação peremptória que a prefeitura faz de que os cortiços constituem um problema irrelevante, seja pelo grande interesse do setor imobiliário que este processo de degradação continue. [...] O velhinho com a esposa e filho, que mora naquele imóvel que ocupa $200 \mathrm{~m}^{2}$. De um lado uma grande oficina, do outro já tem um imóvel que virou cortiço, e claro que na frente já tem uma gafieira. Ele percebe que o valor do seu imóvel está caindo, e periodicamente vem o representante do setor imobiliário tentando comprar e acaba que ele vende. E quando ele vende - surpresa! O cara não faz nada com o imóvel dele, levanta alguma coisa no quintal, ou monta um escritório de despachante, ou demole tudo e faz um estacionamento, ou põe já 10, 15 moradores onde antes viviam três. $E$ as estatísticas não mostram isso, caracterizam como moradia transitória. A população da área central é subestimada, pois quando vai se fazer a contagem numa pensão não se considera os "temporários", que na verdade transitam por imóveis do mesmo tipo, na mesma área. O despovoamento se dá - ainda que de forma subestimada - quando em meio a este comércio de compra e venda, e troca de uso, as onze pessoas do cortiço " $X$ " perdem sua moradia, ainda que nos fundos habitem mais vinte. [...] Não há vontade política, ou coragem, para defender esta causa, bancar uma política de renovação que inclua a questão habitacional. O centro de Campinas é uma jóia, sem lapidação. Tem um valor enorme, e que é mantida podre, empoeirada, etc., propositalmente, pensando justamente neste enorme valor que ela tem. Especulando para um momento adequado (idem). 
Assim sendo, observa-se que não houve de fato uma ação que interviesse na questão da habitação coletiva popular existente na área central de Campinas. Mesmo o que chamamos de tentativas ou indícios de reconhecimento da problemática por parte do poder público, na verdade constituem fatos que de alguma forma relacionamse com a temática discutida, mas que em nenhum momento se apresentam enquanto propostas de fato. 


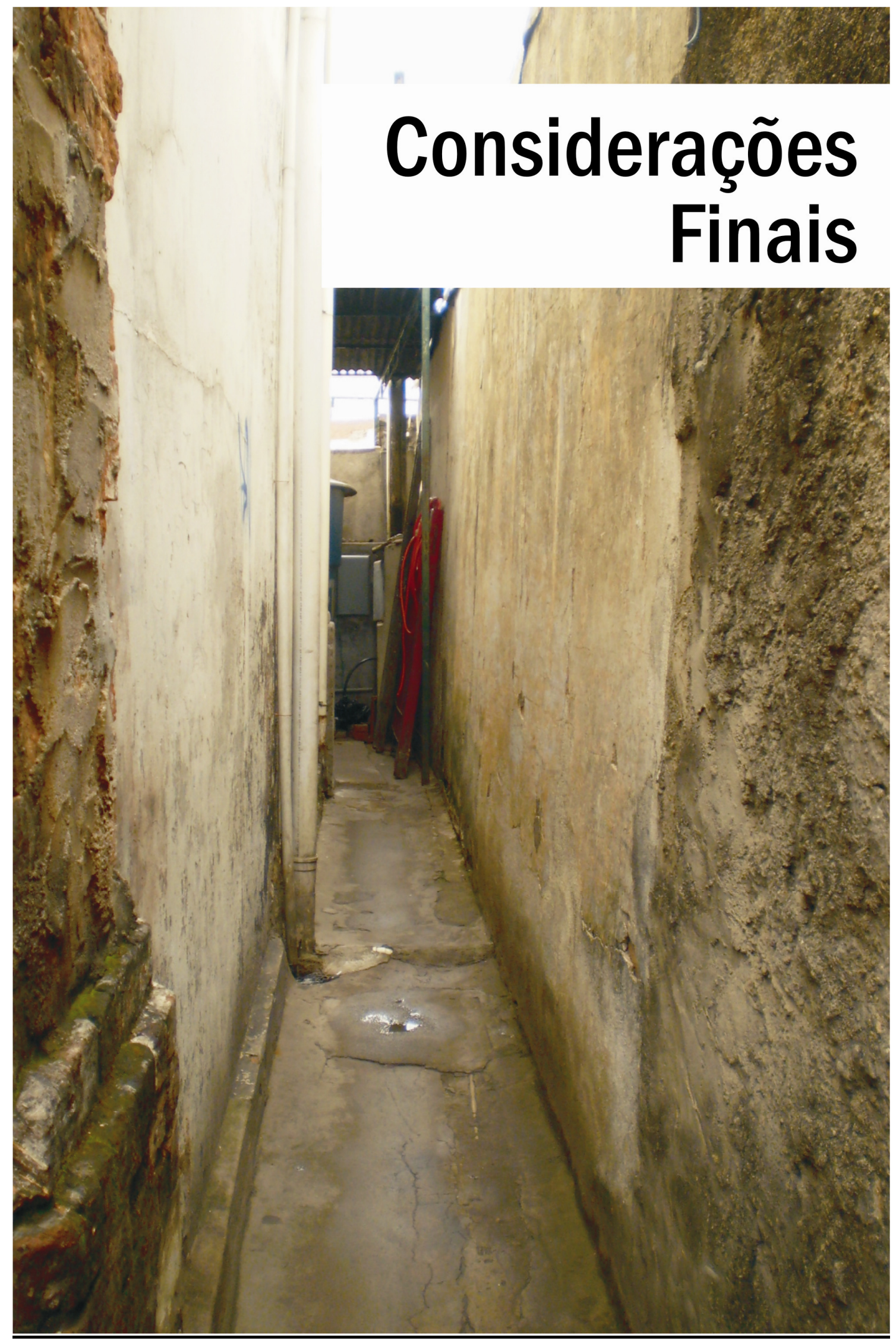


Este trabalho caracterizou e analisou as diferentes configurações de habitações coletivas precárias encontradas na área central de Campinas, a partir da revisão bibliográfica efetuada, que abordou alguns temas centrais à questão habitacional em áreas centrais de grandes cidades brasileiras. Esta revisão considerou também o processo de evolução urbana e o quadro da habitação popular no município de Campinas. As leituras teóricas balizaram as análises realizadas a partir dos levantamentos em campo e em documentos, das quais destacamos as constatações que julgamos mais relevantes.

Uma primeira constatação a ser destacada diz respeito ao empenho em negar a existência de cortiços na área central de Campinas por parte do poder público e da própria população, em contraponto à presença relevante dos mesmos, constatada durante a pesquisa. Através da revisão bibliográfica e das entrevistas realizadas com outros pesquisadores, foi se revelando o jogo de interesses mercadológicos envolvidos na configuração da área central e na questão da habitação coletiva precária especificamente, além da forma como os diferentes atores envolvidos - poder público, mercado imobiliário, proprietário, administrador ou intermediário, moradores e usuários - estabelecem suas relações.

Diante do quadro de abandono por setores de atividades e da população da área central, reforçado e estimulado pelo posicionamento do poder público que pouco faz para reverter esta situação, o valor mercadológico que incide sobre os imóveis do centro sofre quedas consideráveis. Para parte dos proprietários pertencentes às classes de renda média e média alta - já moradores de outras áreas da cidade - a alternativa eleita é aguardar por momento mais propício para negociações, visando sempre obter maior valor com a venda de seus imóveis. Enquanto isso, seus imóveis sofrem alto processo de degradação devido à falta de manutenção, pois bem sabem estes proprietários que o que interessa de fato ao mercado imobiliário é o terreno, onde outros tipos de edifícios, mais voltados às necessidades atuais, poderão ser construídos no lugar dos atuais edifícios residenciais erguidos geralmente na primeira metade do século $X X$. Até que se dê a revalorização almejada, os imóveis são mantidos fechados - com suas aberturas vedadas por paredes de alvenaria - ou passam a se caracterizar como habitações coletivas precárias, com oferta de vagas ou cômodos ao grande contingente da população que prefere morar próximo aos seus locais de trabalho. Nestes casos, como vimos, há a presença do administrador ou intermediário, responsável pelo "negócio" e que faz a intermediação entre o morador e o proprietário do imóvel. Para muitos proprietários de classe de renda baixa ou média 
baixa, cuja única propriedade muitas vezes é aquela edificação que ainda lhe serve como moradia na área central, a alternativa freqüentemente adotada é vender seu imóvel, mesmo que desvalorizado, e ir morar em outros bairros da cidade. A pressão pela venda é grande e, em geral, é exercida sobre um conjunto de edificações, pois ao mercado imobiliário interessam grandes áreas, para grandes empreendimentos. Enquanto a unificação dos lotes não acontece, observamos os já adquiridos transformando-se em estacionamentos ou habitações coletivas, algo que gere algum rendimento e ocupação, além de estimular a degradação do entorno imediato.

É diante deste quadro que se faz cada vez mais presente a habitação coletiva precária, sob a forma de cortiços, pensões ou hotéis populares, ou ainda invasões, como forma de obtenção de rendimentos seja para própria subsistência, ou para custeio de manutenções e taxas incidentes sobre o edifício. As forças que atuam sobre este processo são muito fortes e, aliadas à falta de prioridade política conferida ao problema, contribuem para manter esta condição de negação da questão tanto por parte do próprio poder público como por parte da população de maneira geral. Enquanto isso, dissemina-se a idéia de que a área central está abandonada, degradada, em contínuo processo de esvaziamento, e que a solução estaria na "revitalização", "reestruturação" ou "revalorização" da mesma, pautada em ações de embelezamento e alterações viárias.

O segundo ponto a ser salientado diz respeito à permeabilidade existente entre as diferentes configurações analisadas e suas especificidades. Durante a pesquisa de campo e no aprofundamento de algumas análises, pudemos observar que as habitações coletivas precárias encontradas no perímetro de estudo definido para a pesquisa, ora apresentavam certas especificidades naquilo que as caracterizava, mostrando que existiam ali diferentes configurações habitacionais adotadas, ora certas características se tornavam muito permeáveis, porosas. Procuramos assim destacar algumas questões que retratam este quadro.

A degradação física das edificações, por exemplo, foi constatada em praticamente todas as modalidades de habitações coletivas precárias levantadas pela pesquisa. As causas dessa degradação é que se diferenciam e é importante serem analisadas, pois auxiliam na caracterização das diferentes configurações encontradas. Em geral, se dá pela falta de manutenção e pelas adaptações construtivas realizadas. Quando o proprietário é morador e vive sob as mesmas condições de precariedade dos demais moradores, essa situação está associada à falta de recursos financeiros. 
Quando o proprietário é morador de outra região da cidade e controla o negócio através de um administrador ou intermediário, a degradação acontece, muitas vezes, pela falta de interesse do mesmo em investir em um imóvel, que, na verdade só é mantido para aguardar momento mais propício para venda, considerando as possibilidades de maiores ganhos. Quando o proprietário já é o incorporador imobiliário, a precariedade do imóvel é estímulo à degradação do entorno e manutenção da lógica de interesses estabelecida. Outra característica comum às configurações caracterizadas é o interesse histórico-arquitetônico que a maioria dessas edificações apresentam, fato este comprovado pelo cruzamento dos dados levantados pela pesquisa e o estudo promovido pela Coordenadoria Setorial de Patrimônio Cultural, da cidade de Campinas, que identificou que os focos de habitação coletiva precária localizados no perímetro de estudo coincidem com as manchas apontadas pelo estudo da Coordenadoria para tombamento.

No que diz respeito à organização, destacam-se algumas características como a figura do proprietário no imóvel, que, quando morador, assume as condições precárias de habitabilidade e vê, na locação de vagas ou cômodos, uma forma de adquirir algum rendimento que supra algumas necessidades básicas próprias e da moradia. Em geral, sua presença se dá em edificações degradadas que têm como forma de ocupação o cortiço. Em outros casos, como já mencionado, o proprietário é morador de outra região da cidade e procura na locação de cômodos ou vagas a obtenção de rendimentos que, pelo menos, cubram os gastos com manutenções básicas e taxas incidentes sobre o imóvel, além de manter certa ocupação evitando uma depredação mais aguda. Seu vínculo com o imóvel é mantido através de um administrador ou intermediário, que também é morador do local. Este é um ator cuja importância deve ser destacada, pois além das funções "administrativas" em relação ao cortiço, à pensão ou hotel popular, o administrador também é responsável por estabelecer as regras internas organizacionais, inclusive no que diz respeito às punições e critérios para entrada e saída de um morador. Além disso, é o ponto de contato do poder público com as edificações em questão, pois o proprietário acaba resguardando sua identidade na maioria dos casos. O administrador ou intermediário também aparece quando o proprietário do imóvel já é o incorporador imobiliário, cujo maior interesse imediato acerca do imóvel é o estímulo à degradação do entorno e, conseqüentemente, a possibilidade de compra e remembramento de vários lotes. Percebemos como tais relações são permeáveis e como, com alterações muito sutis 
em seus aspectos, podem ocorrer em diversas das modalidades de moradias coletivas estudadas.

Outro ponto relevante que também demonstra a porosidade existente entre as diferentes configurações de habitação coletiva precária diz respeito à forma como tais moradias se apresentam na área central, ou seja, como as identificamos em meio aos inúmeros elementos que compõem a área central. Algumas edificações normalmente as pensões e hotéis populares - utilizam placas ou anúncios indicativos junto às fachadas. Estas podem ser mais elaboradas e, nestes casos, podem ser do tipo luminoso, dispostos perpendicularmente através de estruturas metálicas e são próprios de locais "mais bem estabelecidos comercialmente". Outras são cartazes feitos à mão livre e condizem com moradias mais precárias que as primeiras. Porém, há casos de edificações que não utilizam nenhum tipo de anúncio indicativo. Nestes casos, só através da observação e levantamento de alguns aspectos - como o grande número de roupas estendidas em áreas comuns, alto fluxo de entrada e saída de pessoas da edificação, contato direto com os moradores e coleta de depoimentos dos mesmos - foi possível constatar que tais edificações funcionavam como habitações coletivas precárias.

Uma terceira constatação relevante da pesquisa refere-se à transitoriedade como característica fundamental no estabelecimento das relações entre os moradores, e entre os mesmos e a moradia, e como isso dificulta as análises e quantificações acerca da questão. O morador de cortiço está a muito mais tempo no município - é natural de Campinas ou está morando na cidade a mais de 10 anos - que o morador de pensão ou hotel popular ou que o habitante de edifícios invadidos. Nestes, os moradores, em geral, são migrantes de outras regiões do país ou outros países sulamericanos. "Forasteiros", como denominados por grande parte dos próprios moradores durante a pesquisa de campo. Também é importante destacar que nos cortiços, assim como nos prédios invadidos, é mais comum encontrarmos famílias inteiras morando no mesmo edifício - avô, avó, pai, mãe, filhos, tios, etc. Nas pensões e hotéis os moradores vivem, em geral, desacompanhados. Em todas as modalidades, a transitoriedade com relação à moradia é grande - a maioria fica de 1 a 3 anos morando no mesmo local - seja ela cortiço, pensão, hotel ou edifício invadido. Porém, encontramos alguns casos em cortiços e em edifícios invadidos, onde os moradores já conviviam juntos há pelo menos 10 anos. 
A transitoriedade se dá por diversos fatores: procura de diminuição de gastos com a moradia, buscando-se sempre lugares com preços "promocionais"; busca por conforto e privacidade, pois em alguns lugares encontram-se cômodos com menos vagas disponíveis, ou seja, menos superlotados, ou ainda com mais conjuntos sanitários disponíveis; busca pela impessoalidade nas relações, principalmente no caso dos "forasteiros" cujo passado, inclusive criminal em alguns casos, ninguém conhece. O tempo de permanência no local de moradia ou o tempo de convivência entre os moradores, também é determinante em grande parte pelo desenvolvimento ou não de "espírito de solidariedade" e ajuda mútua entre os mesmos. Nos cortiços e edifícios invadidos, onde o tipo familiar usual é aquele mais completo, observamos a divisão de algumas tarefas entre as pessoas, inclusive de núcleos familiares diferentes. Entre as tarefas compartilhadas estão a limpeza da calçada e áreas comuns, o acompanhamento das crianças, mesmo que de outra família, à creche ou escola, a execução de refeições e as atividades relacionadas à principal atividade desenvolvida por eles, a reciclagem.

Assim, analisar e caracterizar as diferentes configurações de habitações coletivas precárias na área central de Campinas, a partir de observações "in loco" e da coleta de depoimentos com diversos atores envolvidos, nos imbuíram de algumas respostas e novos questionamentos, próprios de uma situação que se encontra em processo de desenvolvimento e constante transformação. Um tema que se insere no urbano, que, num processo dialético, constrói e é construído pelas redes sociais em diversos níveis, nunca se esgota e sempre nos coloca a possibilidade de reinterpretações. Dessa forma, procuramos colaborar para uma maior inserção da cidade de Campinas nos debates acerca da presença de habitação coletiva precária em áreas centrais de grandes cidades brasileiras. Procuramos também contribuir para o conhecimento da habitação coletiva popular existente na área central de Campinas, investigando quem são seus moradores, administradores e proprietários, sua forma espacial e de funcionamento. Procuramos, sobretudo, destacar como esta é uma questão de grande relevância para o estudo da habitação nas grandes cidades brasileiras. 


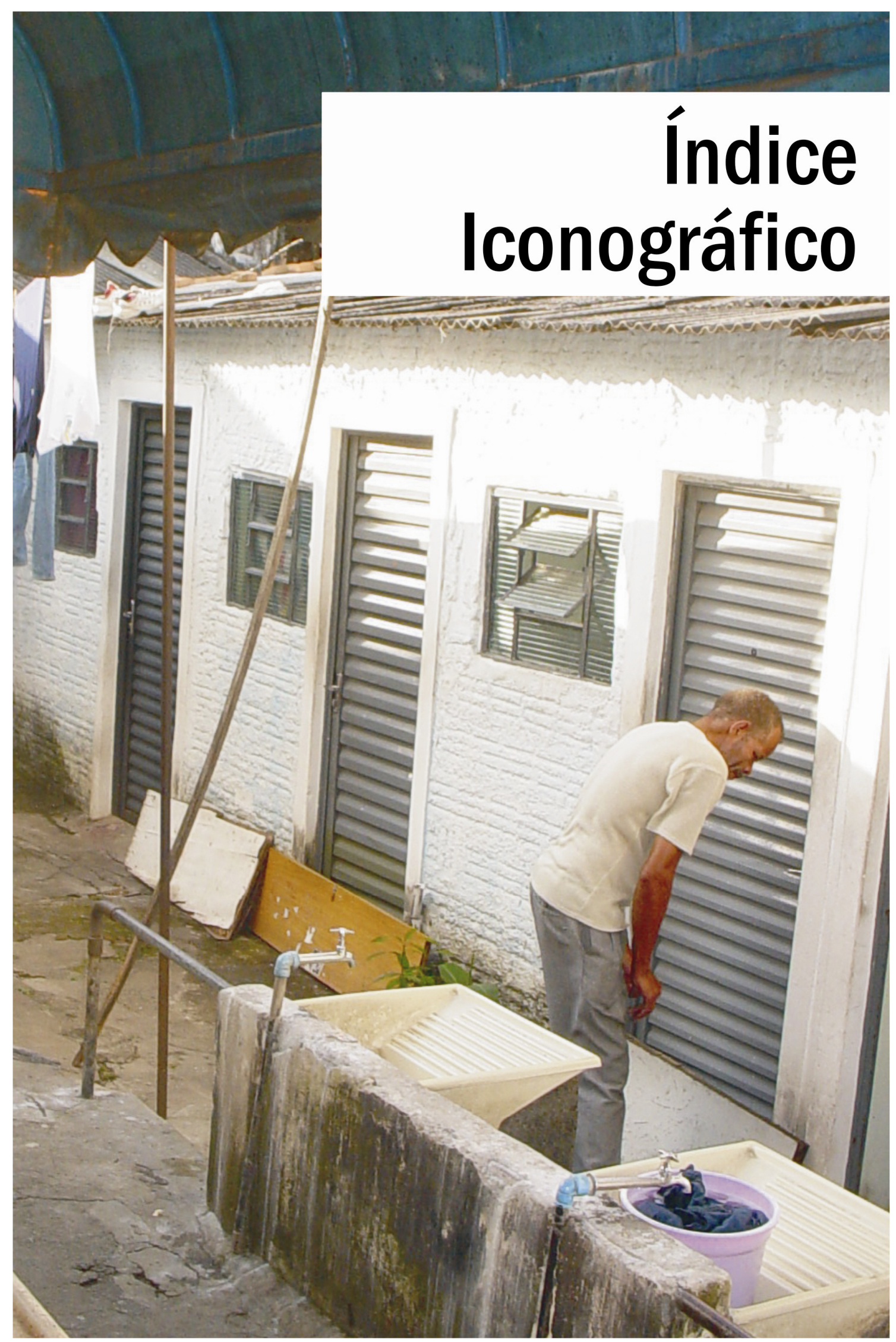


FIGURA 1 Planta de um trecho do bairro Santa Ifigênia com a indicação dos cortiços

FIGURA 2 Planta tipo do modelo de moradia operária proposto pela Comissão 32 de Exame e Inspeção de Cortiços, em 1893.

FIGURA 3 Vista geral do complexo de cortiços formado pelo "Navio Parado", 34 "Vaticano", "Geladeira" e "Pombal", no bairro Bexiga, em São Paulo. Forte símbolo da produção rentista em São Paulo da década de 1920.

FIGURA 4 Planta do complexo de cortiços formado pelo "Navio Parado", 34 "Vaticano", "Geladeira" e "Pombal", no bairro Bexiga, em São Paulo.

FIGURA 5 Evolução da Ocupação de Domicílios encortiçados no município de 42 Santos do século XIX ao ano 2000.

FIGURA 6 Setores Básicos de Intervenção e Áreas de Influência do Programa 66 de Atuação em Cortiços (PAC) no município de São Paulo.

FIGURA 7 Setor Básico de Intervenção e Áreas de Influência do Programa de Atuação em Cortiços (PAC) no município de Santos.

FIGURA 8 Mapa de Campinas em 1878.

FIGURA 9 Mapa de Campinas em 1900.

FIGURA 10 Mapa de Campinas em 1929.

FIGURA 11 Plano de Melhoramentos Urbanos de Prestes Maia (planta base da cidade de Campinas em 1929).

FIGURA 12 Malha Rodoviária da Região Metropolitana de Campinas (RMC).

FIGURA 13 Perímetro Urbano de Campinas.

FIGURA 14 Crescimento Urbano de Campinas (RMC)

FIGURA 15 Loteamentos aprovados de Campinas.

FIGURA 16 Condomínios Horizontais Fechados no município de Campinas 110 
(1976-2005).

FIGURA 17 Favelas, Ocupações Irregulares e Áreas de Concentração de 111 Condomínios e Loteamentos Fechados em Campinas na década de 2000.

FIGURA 18 Perímetro de Estudo e suas respectivas áreas.

FIGURA 19 Hotel popular com presença de atividades ligadas à prostituição Rua Ferreira Penteado, ํㅜ 80

FIGURA 20 Edifício à venda, com destaque as aberturas vedadas

Rua Barata Ribeiro x Rua Barão de Atibaia

FIGURA 21 Concentração de redes hoteleiras

Av. Aquibadan

FIGURA 22 Concentração de habitações coletivas precárias

Rua Irmã Serafina, №249 a 257

FIGURA 23 Túnel subterrâneo para travessia da linha férrea para pedestres

Estação Ferroviária Paulista

FIGURA 24 Vista geral Área 4

Rua 24 de Maio com Rua Monteiro Lobato

FIGURA 25 Vila Manoel Dias

FIGURA 26 Vila Manoel Freire

FIGURA 27 Passagem para vila operária da Estação Ferroviária Mogiana Rua Professor João Lourenço Rodrigues

FIGURA 28 Mapa e Levantamento da Área 2

FIGURA 29 Mapa e Levantamento da Área 3

FIGURA 30 Mapa e Levantamento da Área 4 
FIGURA 31 Mapa e Levantamento da Área 5

FIGURA 32 Mapa e Levantamento da Área 6

FIGURA 33 Conjunto arquitetônico com alguns imóveis tendo uso habitacional 142 coletivo

Rua Marechal Deodoro, no 776, 784, 786, 796

FIGURA 34 Seqüência de imóveis: "Pensão Estrela", "Pensão Familiar" e 143 Estacionamento "RCS Park"

Rua Dr. Mascarenhas, no 387, 391, 415

FIGURA 35 Imóvel com alto grau de degradação e uso habitacional coletivo

Rua General Osório, ㄲo 79

FIGURA 36 Imóvel com alto grau de degradação e uso habitacional coletivo

Rua General Osório, nº 79

FIGURA 37 Mapa com a delimitação da área de estudo do

"Inventário da Região Central de Campinas".

FIGURA 38 Perímetro de Estudo adotado para a pesquisa, com cruzamento dos dados resultantes do "Inventário da Região Central de Campinas" e pesquisa de campo.

FIGURA 39 Edificação degradada

Rua 11 de Agosto x Rua 13 de Maio

FIGURA 40 Edificação degradada

Rua Cônego Cipião, no 203

FIGURA 41 Edificação degradada com incidência de ocupação por invasão

Rua Visconde do Rio Branco, ํㅜ 777

FIGURA 42 Edificação inacabada invadida

Rua Barão de Parnaíba, entre Ruas Benjamin Constant e Barreto Leme 
FIGURA 43 Edificação inacabada invadida

Rua Com. José Luiz Pereira de Queiroz, Ruas Dr. Delfino Cintra e Prof. Luiz Rosa

FIGURA 44 Edificação abandonada com aberturas vedadas

Rua Bernardino de Campos, no 402

FIGURA 45 Edificação abandonada

Rua Cônego Cipião, nำ438

FIGURA 46 Edificação abandonada

Rua Álvares Machado, nº 338

FIGURA 47 Área comum de um dos cortiços levantados pela pesquisa

Rua Dr. Ricardo, ำ 496

FIGURA 48 Área comum de um dos cortiços levantados pela pesquisa

Rua Dr. Ricardo, no 496

FIGURA 49 Interior de um dos cômodos, com destaque ao "fogareiro" no chão, 154 próximo ao colchão de um dos moradores e banheiro interno ao cômodo, com roupas estendidas

Rua do Rocio, ำ 32

FIGURA 50 Interior de um dos cômodos, com destaque ao "fogareiro" no chão, 154 próximo ao colchão de um dos moradores e banheiro interno ao cômodo, com roupas estendidas

Rua do Rocio, no 32

FIGURA 51 Interior de um dos cômodos, com destaque à "cabine" construída, 155 ora com alvenaria $(h=2,0 m)$, ora com madeirite, dentro do cômodo, contendo um vaso sanitário e um chuveiro

Rua Dr. Ricardo, ำ 496

FIGURA 52 Interior de um dos cômodos, com destaque à "cabine" construída, 155 ora com alvenaria $(h=2,0 m)$, ora com madeirite, dentro do cômodo, contendo um vaso sanitário e um chuveiro

Rua Dr. Ricardo, № 496 
FIGURA 53 Cômodos construídos em alvenaria de bloco de concreto no recuo 156 lateral do imóvel, com tanques e pia de uso comum aos moradores

Rua General Osório, ํㅜ 69

FIGURA 54 Cômodos construídos em alvenaria de bloco de concreto no recuo 156 lateral do imóvel, com tanques e pia de uso comum aos moradores

Rua General Osório, ㄲo 69

FIGURA 55 Corredor lateral de acesso aos cômodos do "fundo" e interior de um dos quartos (para 4 pessoas)

Rua Dr. Ricardo, no 496

FIGURA 56 Corredor lateral de acesso aos cômodos do "fundo" e interior de um 157 dos quartos (para 4 pessoas)

Rua Dr. Ricardo, № 496

FIGURA 57 "Pensão Azul" e "Pensão Familiar" (restrição de gênero)

Rua Dr. Mascarenhas, ํo 428 e 238

FIGURA 58 "Pensionato 5 estrelas" 159

(à presença de crianças)

FIGURA 59 Anúncio à mão livre indicando a locação de vagas 160 Rua Dr. Ricardo, № 504

FIGURA 60 Anúncios indicando a locação de vagas

Rua Dr. Ricardo, nำ 504

FIGURA 61 Anúncio de vagas junto ao portão de acesso à edificação

Rua Barão de Jaraguá, no 404 e 426

FIGURA 62 Anúncio de vagas junto ao portão de acesso à edificação

Rua Barão de Jaraguá, no 404 e 426

FIGURA 63 Concentração de "pensões e hotéis populares"

Rua Barão de Parnaíba, nº 629

FIGURA 64 Concentração de "pensões e hotéis populares" 
Rua 11 de Agosto, № 719 e 729

FIGURA 65 Edifício inacabado invadido

Rua Com. José Luiz Pereira de Queiroz, Ruas Dr. Delfino Cintra e Prof. Luiz Rosa

FIGURA 66 "Apartamento" do pavimento térreo

Rua Com. José Luiz Pereira de Queiroz, Ruas Dr. Delfino Cintra e Prof. Luiz Rosa

FIGURA 67 Interior de um dos "apartamentos" do subsolo

Rua Com. José Luiz Pereira de Queiroz, Ruas Dr. Delfino Cintra e Prof. Luiz Rosa

FIGURA 68 Interior do "apartamento" da família do zelador, localizado no 165 pavimento térreo e área adjacente onde se faz separação de lixo reciclável

Rua Com. José Luiz Pereira de Queiroz, Ruas Dr. Delfino Cintra e Prof. Luiz Rosa

FIGURA 69 Interior do "apartamento" da família do zelador, localizado no 165 pavimento térreo e área adjacente onde se faz separação de lixo reciclável

Rua Com. José Luiz Pereira de Queiroz, Ruas Dr. Delfino Cintra e Prof. Luiz Rosa

FIGURA 70 Armazenagem de água

Rua Com. José Luiz Pereira de Queiroz, Ruas Dr. Delfino Cintra e Prof. Luiz Rosa 


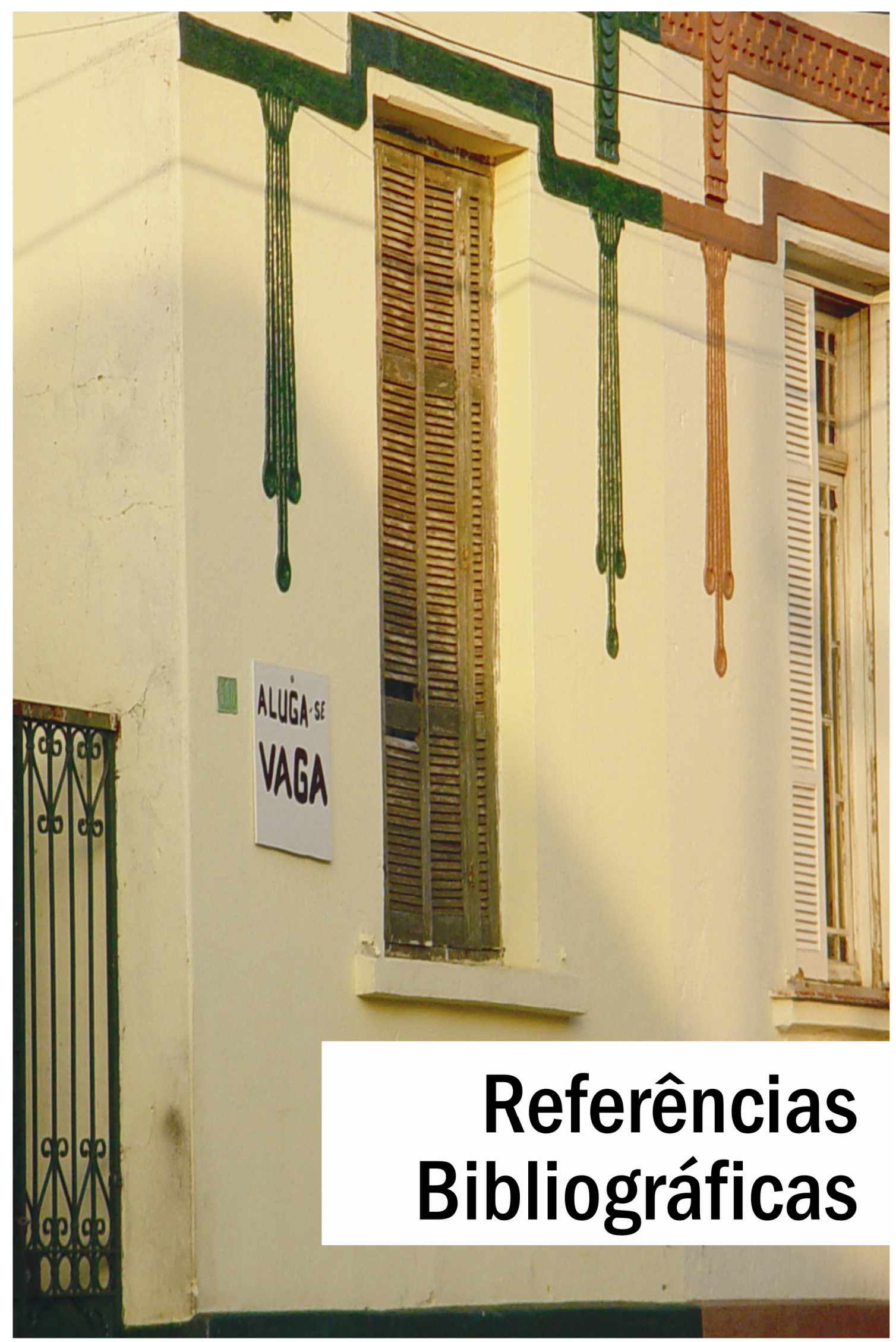


ABREU, Mauricio de. Da habitação ao habitat: A questão da habitação popular no Rio de Janeiro e sua evolução. In: Revista do Rio de Janeiro, n 2, abr. 1986.

ALMEIDA, Marco Antonio Ramos (ap.). Os centros das metrópoles: reflexões e propostas para a cidade democrática do século XXI. São Paulo: Editora Terceiro Nome: Viva o Centro: Imprensa Oficial do Estado, 2001.

ALVARO, Guilherme. A campanha sanitária em Santos. São Paulo, 1919.

AMADIO, Décio. Alguma coisa acontece... uma investigação sobre o centro de São Paulo. Dissertação (Mestrado). São Paulo: Faculdade de Arquitetura e Urbanismo da Universidade de São Paulo (FAU-USP), 1998.

ANDRADE, Carlos Roberto Monteiro de. A peste e o plano: o urbanismo sanitarista do engenheiro Saturnino de Brito. São Paulo, 1992.

ANDRADE, Wilma Terezinha F. de. 0 discurso do progresso: a evolução urbana de Santos (1870-1930). São Paulo, 1989.

ASCHER, François. Metropolização e transformação dos centros das cidades. In: ALMEIDA, Marco Antonio Ramos (ap.). Os centros das metrópoles: reflexões e propostas para a cidade democrática do século XXI. São Paulo: Editora Terceiro Nome: Viva o Centro: Imprensa Oficial do Estado, 2001. p. 59-68.

AUDEFROY, Jöel. Vivir em los Centros históricos. Experiências e luchas de los habitantes para permanecer em los centros históricos. México D.F. Coalición Internacional para el Hábitat, 1999.

AZEVEDO, Aluísio de. O Cortiço. São Paulo: L\&MP, 2002.

BADARÓ, Ricardo de Souza Campos. Campinas: o despertar da modernidade. Campinas: Área de Publicações CMU/ UNICAMP, 1996.

Área Central de Campinas. Campinas: Prefeitura Municipal de Campinas, 2002.

O Plano de Melhoramentos de Campinas (1934-1962). São Carlos, Departamento de Arquitetura e Urbanismo, EESC, 1986, p.52. 
BAENINGER, Rosana. Região Metropolitana de Campinas: expansão e consolidação do urbano paulista. Campinas: NEPO/UNICAMP, 2000.

BARROS, Francisco Toledo. Limites à Produção Pública de Moradia Social no centro de São Paulo. Pesquisa de Iniciação Científica PIBIC-CNPQ, FAU-USP, São Paulo, 2002. Relatório Final.

BITTENCOURT, Luiz Cláudio. Centro Histórico. In: Campinas: História do Urbanismo. Oculum - Ensaios, no2: Campinas, 2002, p. 130-139.

BONDUKI, Nabil. Origens da Habitação Social no Brasil: arquitetura moderna, lei do inquilinato e difusão da casa própria. São Paulo: Estação Liberdade, 4 ed., 2004.

Habitar São Paulo: reflexões sobre a gestão urbana. São Paulo: Estação Liberdade, 2000.

et al. Comissão de Estudos sobre habitação na área central. São Paulo: Câmara Municipal de São Paulo, set./2001. Relatório final. Disponível em: http://www.camara.sp.gov.br/central_de_arquivos/vereadores/CEhabita\%C3\%A7\%C3\%A3o.pdf

BORJA, Jordi. Urbanização e Centralidade. In: ALMEIDA, Marco Antonio Ramos de (et al). O Centro da Metrópole: reflexões e propostas para a cidade democrática do século XXI. São Paulo: Editora Terceiro Nome: Viva o Centro: Imprensa Oficial do Estado, 2001, p. 69-86.

BRESCIANI, Stella (org.). Imagens da cidade - séculos XIX e XX. São Paulo: ANPUH/ São Paulo/ Marco Zero/ FAPESP, 1994.

Metrópolis: as faces do monstro urbano (as cidades do século XIX). Revista Brasileira de História. São Paulo, no e 9: 35-68, 1985.

BOUCHE, Nancy. A Reabilitação na França: instrumentos e procedimentos. In: Gestão de Programas de Reabilitação Urbana. São Paulo: Ecole Nationale des Ponts et Chaussées (ENPC), Federação Nacional das associações Pact-Arim e Labhab/FAUUSP, 2000. 
CAIADO, Maria Célia da Silva e PIRES, Maria Conceição Silvério. Expansão Recente na Região Metropolitana de Campinas: Dispersão e Novas Formas Urbanas. In: REIS, Nestor Goulart. Brasil: Estudos sobre Dispersão Urbana. São Paulo: FAU-USP, 2007, p. 81-111.

CANO, Wilson \& BRANDÃO, Carlos A (coords.). A Região metropolitana de Campinas: urbanização, economia, finanças e meio ambiente. Campinas: Editora da UNICAMP, 2002.

CARICARI, Ana Maria e KOHARA, Luiz. (org). Cortiços de São Paulo: soluções viáveis para habitação social no centro da cidade e legislação de proteção à moradia. São Paulo, Mídia Alternativa: CESE, 2006.

CARPINTERO, Antonio Carlos Cabral. Momento de Ruptura: As transformações no centro de Campinas na década dos cinqüenta. Dissertação de Mestrado, FAUUSP, São Paulo, 1991.

CASTAN. Scenas da abolição. São Paulo, 1924.

CHAUÍ, Marilena. O que é ideologia? São Paulo, 1981.

CONSTANTINO, Lygia Gonçalves. Habitação Popular em Campinas: Ação e Identidade. Tese de Doutorado, FAU-USP, São Paulo, 1997.

CORREIA, Telma B. A Construção do Habitat Moderno no Brasil, 1870-1950. São Carlos: RIMA, 2004.

DIOGO, Érica Cristina Castilho. Habitação Social no contexto da reabilitação urbana da Área Central de São Paulo. São Paulo: FAUUSP, 2004. Dissertação de Mestrado.

Dossiê de Denúncia - Violações dos Direitos Humanos no centro de São Paulo: propostas e reivindicações para políticas públicas. Fórum Centro Vivo, 2007. Disponível em: http://dossie.centrovivo.org/Main/HomePage

ENGELS, F. A Questão da Habitação. São Paulo: Editora Acadêmica, 1988. 
FERNANDES, Ari Vicente. Urbanização x Recursos Hídricos - A necessária compatibilização entre Diretrizes Regionais e Intervenções Locais. Tese de Doutoramento, FAU-USP, São Paulo, 2004.

FERNANDES, Florestan. Capitalismo dependente e classes sociais na América Latina. Rio de Janeiro: Zahar, 1973, p. 33-43.

FERREIRA, Aurélio Buarque de Holanda. Dicionário da Língua Portuguesa. São Paulo: Nova Fronteira, 1988.

FIPE/ SEHAB. Fundação Instituto de Pesquisas Econômicas e Secretaria de Habitação do Município de São Paulo. Cortiços em São Paulo: Relatório gerencial. São Paulo: Fipe/ Sehab, 1994, mimeo.

FIPE. Diagnostico e plano de ações para o mercado de moradia de aluguel e identificação de obstáculos para aquisição de novas moradias pelas famílias de baixa renda. Vol I. outubro/1997, p.54.

FONSECA, Rinaldo Barcia; DAVANZO, Áurea M. Q.; NEGREIROS, Rovena M.C. (orgs.). Livro Verde: desafios para a gestão da Região Metropolitana de Campinas. Campinas: Editora da UNICAMP, 2002.

FRÚGOLI Jr. Heitor. Centralidade em São Paulo: Trajetórias, Conflitos e Negociações na Metrópole. São Paulo: Editora da Universidade de São Paulo, 2006.

Fundação Instituto de Pesquisas Econômicas (FIPE). Levantamento socioeconômico da região central da cidade de São Paulo (relatório final). São Paulo, out. 1995.

GAMBETA, Wilson. Desacumular a pobreza. Santos, Limiar do século. In: Espaço e Debates, n. 11, São Paulo, 1984, p.25

Gestão do uso do solo e disfunções do crescimento urbano: instrumentos de planejamento e gestão urbana: São Paulo e Campinas. IPEA/ INFURB/ UNICAMP/ IE/ NESUR. Brasília: IPEA, 2001.

GONÇALVES, Maria Flora. Novas configurações no desenvolvimento urbano paulista. Espaço \& Debates, no8: São Paulo, 1994, p. 39-53. 
GUALTIERI, Benedito Roberto. Legislação Habitacional de Campinas: Conversas e controvérsias. Faculdade de Arquitetura e Urbanismo da PUC Campinas (Dissertação de Mestrado), 2001.

KOHARA, Luiz Tokuzi. Rendimentos obtidos na locação e sublocação de cortiços: estudos de casos na área central da cidade de São Paulo. Dissertação de Mestrado, FAU-USP, São Paulo, 1999.

KOWARICK, L.; ANT, C. O cortiço: Cem anos de promiscuidade. Novos Estudos Cebrap, ํo2, p. 59-70, abr. 1982.

Os cortiços no centro de São Paulo: História \& etnografia. 2004, mimeo

LAGENEST, H. D. de B. Os cortiços em São Paulo. Revista Anhembi. São Paulo, nำ139, 1962.

LAPA, José Roberto do Amaral. A Cidade, os Cantos e os Antros. Campinas: 18501900. São Paulo: Editora da Universidade de São Paulo, 1996.

LANNA, Ana Lúcia Duarte. Uma cidade na transição: Santos 1870-1913. Santos: Hucitec/PM, 1996. Tese (doutorado).

LEME, Maria Cristina da Silva; MOREIRA, Antônio Cláudio; PASTERNAK, Suzana. 0 cortiço e a precarização das condições de vida na cidade de São Paulo. In: VIII SEMINÁRIO INTERNACIONAL DA REDE IBERO-AMERICANA DE INVESTIGADORES SOBRE A GLOBALIZAÇÃO E TERRITÓRIO, Rio de Janeiro, 25 a 28 de maior de 2004.

LEMOS, C. Os primeiros cortiços paulistanos. In: SAMPAIO, Maria Ruth (coord.). Habitação e Cidade. São Paulo, FAU-USP/ Fapesp, 1998, p. 9-38.

LENCIONI, Sandra. Reestruturação urbano-industrial no Estado de São Paulo: a região da metrópole desconcentrada. Espaço \& Debates, nํ38: São Paulo, 1994, p. 54-61. 
LENCIONI, Sandra. Restruturação urbano-industrial no Estado de São Paulo: a região da metrópole desconcentrada. In: SANTOS et alii (orgs.) Território, Globalização e fragmentação. São Paulo: HUCITEC/ ANPUR, 1994, p. 198-210.

LENCIONI, Sandra. O processo de metropolização e regionalização. In: Schiffer, S. org.) Globalização e estrutura urbana. São Paulo, HUCITEC, 2004, p. 153-165.

LIPIETZ, Alain. O local e o global: personalidade regional ou inter-regionalidade? Espaço \& Debates, no38: São Paulo, 1994, p. 10-20.

MARICATO, Ermínia. Metrópole na periferia do capitalismo: ilegalidade, desigualdade e violência. São Paulo: HUCITEC, 1996.

MARICATO, Ermínia. Comentários. In: ALMEIDA, Marco Antonio Ramos de (et al). $O$ Centro da Metrópole: reflexões e propostas para a cidade democrática do século XXI. São Paulo: Editora Terceiro Nome: Viva o Centro: Imprensa Oficial do Estado, 2001, p.93-97.

MARICATO, Ermínia. Habitação Social em Áreas Centrais. In: Campinas: História do Urbanismo. Oculum - Ensaios, noㅇ: Campinas, 2002, p. 14-24.

- Reabilitação de centros urbanos e habitação social. In: MARICATO, E. Brasil, cidades. Alternativas para a crise urbana. São Paulo: Vozes, 2001.

Paulo: Vozes, 2001.

Brasil, cidades. Alternativas para a crise urbana. São Habitação Social em Áreas Centrais. In: Campinas: História do Urbanismo. Oculum - Ensaios, no02: Campinas, 2002, p. 14-24.

MATOS, Odilon Nogueira de. Um pouco da história de Campinas. Campinas: PUCCAMP, Departamento de História, 1985.

MEYER, Regina P. A construção da metrópole e a erosão do seu Centro. In: Revista Urbs, ano II, №14 - set/out 1999 - p.28-36.

MIRANDA, Zoraide Amarante Itapura de. A incorporação de áreas urbanas rurais as cidades: um estudo de caso sobre Campinas/ SP. Campinas: (s.n.), 2002. 
MOREIRA, Antônio Cláudio Moreira Lima e. Políticas públicas habitacionais em São Paulo. São Paulo; FAUUSP, 1999. (sumário de aula).

(Coord.) Territorialidade da globalização em São Paulo. Relatório Fase 1, Projeto de Pesquisa Políticas Públicas Fapesp, 2002.

(org.); LEME, Maria Cristina da Silva; NARUTO, Minoru; PASTERNAK, Suzana. Intervenção em cortiço: uma experiência didática. São Paulo: FAUUSP, 2006.

MORETTI, Ricardo de Sousa e JANUZZI, Paulo de Martino. Política Habitacional na Região Metropolitana de Campinas. In: Livro Verde: desafios para a gestão da Região Metropolitana de Campinas (org). Campinas: Unicamp/ IE, 2002, p.283-301.

MOTTA, Cesário. Relatório de Comissão de Exame e Inspeção das Habitações Operárias e Cortiços no Distrito de Santa Iphigênia. In: BONDUKI, Nabil. Origens da Habitação Social no Brasil. Arquitetura Moderna, Lei do Inquilinato e Difusão da Casa Própria. São Paulo: Estação Liberdade/ Fapesp, 1988, p.27.

NEGRI, Barjas e PACHECO, Carlos Américo. Mudança tecnológica e desenvolvimento regional nos anos 90: a nova dimensão espacial da indústria paulista. Espaço \& Debates, no38: São Paulo, 1994, p. 62-82.

NEGRI, Barjas. Concentração e desconcentração industrial em São Paulo (18801990). Campinas: Editora da UNICAMP, 1996.

PASTERNAK, S.; BOGUS, L. Continuidades e descontinuidades na cidade de anéis. 2004, mimeo.

PASTERNAK, S. Habitação e demografia intra-urbana. Revista Brasileira de Estudos de População, v. 7, no1, p. 3-34, 1990.

PICCINI, A. Cortiços na cidade: Conceitos e Preconceitos na reestruturação do centro urbano de São Paulo. São Paulo: Annablume, 1999.

PORTAS, Nuno. Notas sobre a intervenção na cidade existente. Espaço \& Debates, Ano VI, 1986, no 17: 94-104. 
PORTAS, Nuno. As políticas de reforço das centralidades. In: ALMEIDA, Marco Antonio Ramos de (et al). O Centro da Metrópole: reflexões e propostas para a cidade democrática do século XXI. São Paulo: Editora Terceiro Nome: Viva o Centro: Imprensa Oficial do Estado, 2001, p.121-134.

Prefeitura Municipal de Campinas. Inventário da Região Central de Campinas. Campinas, 2008. Relatório Final.

Prefeitura Municipal de Campinas. Resoluções da 1a Conferência Municipal de Habitação. Campinas, março de 2002. Relatório Final.

Programa de Atuação em Cortiços - PAC: Município de Santos e São Paulo Setores Básicos de Intervenção. São Paulo: CDHU/ SEADE, 2002. (Relatório executivo).

PUPPO, Celso Melo. Campinas, seu berço e juventude. Campinas: Academia Campinense de Letras, 1969.

RIBEIRO, Cláudia Maria Lima. Ou é casa ou é nada: um estudo sobre a lógica de ocupação dos espaços construídos à margem da legislação no município de Campinas. Dissertação de Mestrado. PUC - Campinas, 2006.

ROLNIK, Raquel. A cidade e a lei. Legislação, Política Urbana e territórios na cidade de São Paulo. São Paulo: FAPESP/ Studio Nobel, 1997.

ROSSETTO, Rossella. Arquitetura Moderna e tipologias de mercado: uma primeira classificação. In: SAMPAIO, M. (org). A promoção privada de habitação econômica e a arquitetura moderna, 1930-1964. São Carlos: RIMA, 2002, p. 29-51.

SACHS, Celine. São Paulo: Políticas Públicas e Habitação Popular. São Paulo: Editora da Universidade de São Paulo, 1999.

SAMPAIO, Maria Ruth Amaral de (org). Habitação e Cidade. São Paulo: FUPAM/FAUUSP/Fapesp, 1998.

SAMPAIO, Maria Ruth Amaral de. A promoção privada da habitação econômica e a arquitetura moderna em São Paulo - 1930/1964. in: SAMPAIO, M. (org). A promoção privada de habitação econômica e a arquitetura moderna, 1930-1964. São Carlos: RIMA, 2002, p. 13-28. 
SAMPAIO, M; ROSSETTO, R. Habitação econômica coletiva - Amostra selecionada. In: SAMPAIO, M. (org). A promoção privada de habitação econômica e a arquitetura moderna, 1930-1964. São Carlos: RIMA, 2002, p.103-113.

SANTOS, Antonio da Costa. Campinas, das origens ao futuro: compra e venda de terra e água e um tombamento na primeira sesmaria da Freguesia de Nossa Senhora da Conceição das Campinas do Mato Grosso de Jundiaí (1732-1992). Campinas: Editora da UNICAMP, 2002.

SÃO PAULO (município). Cortiços em São Paulo. São Paulo: Sebes (Secretaria do Bem-Estar Social), mimeo, 1975.

SÃO PAULO (município). Cortiços de São Paulo: Frente e verso. São Paulo: Sempla, 1985.

SÃO PAULO (estado). Programa de Atuação em Cortiços - PAC: município de São Paulo - setores básicos de intervenção. São Paulo: CDHU-SEADE, 2002.

SÃO PAULO (estado). Programa de Atuação em Cortiços - PAC: município de Santos - setores básicos de intervenção. São Paulo: CDHU-SEADE, 2002a.

SCHIFFER, Sueli (org.). Globalização e estrutura urbana. São Paulo, HUCITEC,2004.

SCHIMIDT, Afonso. A marcha. São Paulo, 1941.

SEMEGHINI, Ulisses. Campinas (1860-1980) - Agricultura, Industrialização e Urbanização. Dissertação de Mestrado, IE, UNICAMP, 1988.

Do Café à Indústria: uma cidade e seu tempo. Campinas/SP: Editora da UNICAMP, 1991.

A Região Administrativa de Campinas. In: SEADE. Cenários de urbanização paulista: regiões administrativas. São Paulo: SEADE, v. 8., 1992.

Gestão Metropolitana, possibilidades e limites: A experiência de Campinas. Campinas, UNICAMP, Instituto de Economia (Tese de Doutorado), 2006.

SILVA, Helena Menna Barreto. Habitação no centro de São Paulo: como viabilizar essa idéia? São Paulo: LabHab/ FAUUSP, 2000. 
O movimento pela reabilitação do centro de SP e a problemática habitacional. São Paulo: LabHab/ FAUUSP 2002.

Apresentação. In: BIDOU-ZACHARIASEN, Catherine (coord.). De volta à cidade: dos processos de gentrificação às políticas de "revitalização" dos centros urbanos. São Paulo: Annablume, 2006. p. 7-19.

SILVA, Paula Francisca Ferreira da Silva. A Expansão Urbana de Campinas através de Condomínios e Loteamentos Fechados (1974-2005). São Carlos, Departamento de Arquitetura e Urbanismo, Escola de engenharia de São Carlos, USP (Dissertação de Mestrado), 2008.

SIMÕES JÚNIOR, José Geraldo. Cortiços em São Paulo: o problema e suas alternativas. Pólis, nํ2, 1991.

SMITH, Neil. A gentrificação generalizada: de uma anomalia local à 'regeneração' urbana como estratégia urbana global. In: BIDOU-ZACHARIASEN, Catherine (coord.). De volta à cidade: dos processos de gentrificação às políticas de "revitalização" dos centros urbanos. São Paulo: Annablume, 2006. p. 59-88.

SOLÀ-MORALES. Manuel de. Espaços Públicos e espaços coletivos. In: ALMEIDA, Marco Antonio Ramos de (et al). O Centro da Metrópole: reflexões e propostas para a cidade democrática do século XXI. São Paulo: Editora Terceiro Nome: Viva o Centro: Imprensa Oficial do Estado, 2001, p. 101-120.

TEIXEIRA, A. C. Cortiço: O pequeno espaço do povo São Paulo. Dissertação (Mestrado), Faculdade de Arquitetura e Urbanismo, Universidade de São Paulo, São Paulo, 1985.

TEIXEIRA DOS SANTOS, A. L. et al. Laboratório integrado e participativo para requalificação de cortiço. São Paulo: FAUUSP, 2002.

TOURINHO, Andréa de Oliveira. Do centro aos centros: bases teórico-conceituais para o estudo da centralidade em São Paulo. Tese (doutorado). São Paulo: Faculdade de Arquitetura e Urbanismo da Universidade de São Paulo (FAU-USP), 2004.

URBINA TELLES, G. O problema do cortiço. Serviço Social, №2, dez. 1940. 
VAZ, L. Contribuição ao estudo da produção e transformação do espaço na habitação popular. As habitações coletivas do Rio antigo. Dissertação (Mestrado), IPPUR/ Universidade Federal do Rio de Janeiro, Rio de Janeiro, 1985.

VILLAÇA, Flávio. Espaço intra-urbano no Brasil. São Paulo: Studio Nobel, 2001. O uso do solo urbano. São Paulo: FPEL, 1978.

ZIMMERMANN, Gustavo. Finanças públicas municipais: o caos de Campinas. Campinas, Instituto de Economia, UNICAMP (Dissertação de Mestrado), 1987. 